\title{
GEOHYDROLOGY OF THE OZARK PLATEAUS AQUIFER SYSTEM IN PARTS OF MISSOURI, ARKANSAS, OKLAHOMA, AND KANSAS
}

\section{RECIONAL ARUIFAR-SYSTIM ANALYSIS}

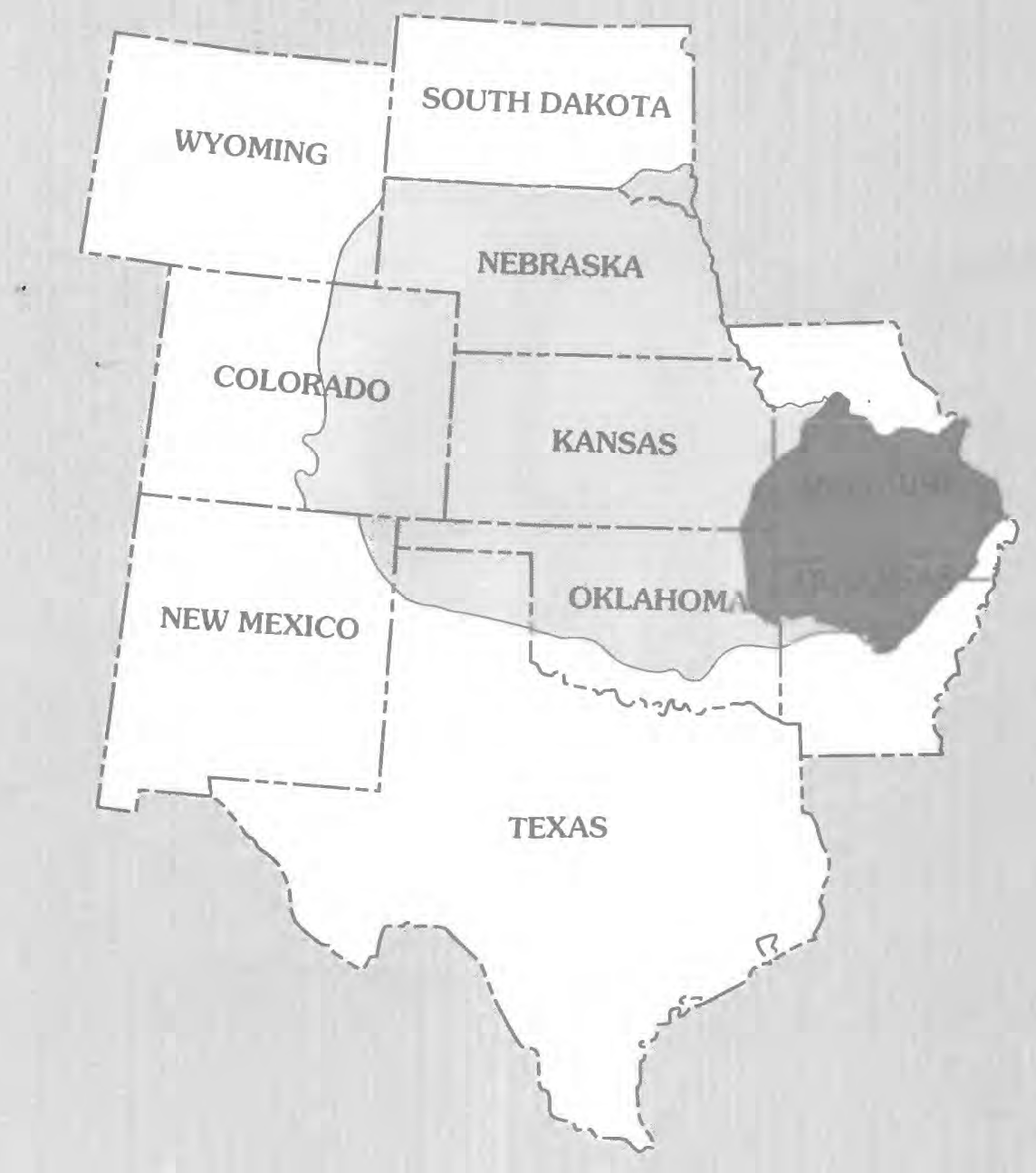

U.S. GEOLOGICAL SURVEY PROFESSIONAL PAPER 1414-D 


\section{SELECTED SERIES OF U.S. GEOLOGICAL SURVEY PUBLICATIONS}

\section{Periodicals}

Earthquakes \& Volcanoes (issued bimonthly).

Preliminary Determination of Epicenters (issued monthly).

\section{Technical Books and Reports}

Professional Papers are mainly comprehensive scientific reports of wide and lasting interest and importance to professional scientists and engineers. Included are reports on the results of resource studies and of topographic, hydrologic, and geologic investigations. They also include collections of related papers addressing different aspects of a single scientific topic.

Bulletins contain significant data and interpretations that are of lasting scientific interest but are generally more limited in scope or geographic coverage than Professional Papers. They include the results of resource studies and of geologic and topographic investigations, as well as collections of short papers related to a specific topic.

Water-Supply Papers are comprehensive reports that present significant interpretive results of hydrologic investigations of wide interest to professional geologists, hydrologists, and engineers. The series covers investigations in all phases of hydrology, including hydrogeology, availability of water, quality of water, and use of water.

Circulars present administrative information or important scientific information of wide popular interest in a format designed for distribution at no cost to the public. Information is usually of shortterm interest.

Water-Resource Investigations Reports are papers of an interpretive nature made available to the public outside the formal USGS publications series. Copies are reproduced on request unlike formal USGS publications, and they are also available for public inspection at depositories indicated in USGS catalogs.

Open-File Reports include unpublished manuscript reports, maps, and other material that are made available for public consultation at depositories. They are a nonpermanent form of publication that may be cited in other publications as sources of information.

\section{Maps}

Geologic Quadrangle Maps are multicolor geologic maps on topographic bases in $71 / 2$-or 15 -minute quadrangle formats (scales mainly $1: 24,000$ or $1: 62,500$ ) showing bedrock, surficial, or engineering geology. Maps generally include brief texts; some maps include structure and columnar sections only.

Geophysical Investigations Maps are on topographic or planimetric bases at various scales; they show results of surveys using geophysical techniques, such as gravity, magnetic, seismic, or radioactivity, which reflect subsurface structures that are of economic or geologic significance. Many maps include correlations with the geology.

Miscellaneous Investigations Series Maps are on planimetric or topographic bases of regular and irregular areas at various scales; they present a wide variety of format and subject matter. The series also includes 7 1/2-minute quadrangle photogeologic maps on planimetric bases that show geology as interpreted from aerial photographs. Series also includes maps of Mars and the Moon.
Coal Investigations Maps are geologic maps on topographic or planimetric bases at various scales showing bedrock or surficial geology, stratigraphy, and structural relations in certain coal-resource areas.

Oil and Gas Investigations Charts show stratigraphic information for certain oil and gas fields and other areas having petroleum potential.

Miscellaneous Field Studies Maps are multicolor or black-andwhite maps on topographic or planimetric bases on quadrangle or irregular areas at various scales. Pre-1971 maps show bedrock geology in relation to specific mining or mineral-deposit problems; post-1971 maps are primarily black-and-white maps on various subjects, such as environmental studies or wilderness mineral investigations.

Hydrologic Investigations Atlases are multicolor or black-andwhite maps on topographic or planimetric bases presenting a wide range of geohydrologic data of both regular and irregular areas; principal scale is $1: 24,000$, and regional studies are at $1: 250,000$ scale or smaller.

\section{Catalogs}

Permanent catalogs, as well as some others, giving comprehensive listings of U.S. Geological Survey publications are available under the conditions indicated below from the U.S. Geological Survey, Books and Open-File Reports Sales, Federal Center, Box 25286, Denver, CO 80225. (See latest Price and Availability List.)

"Publications of the Geological Survey, 1879-1961" may be purchased by mail and over the counter in paperback book form and as a set of microfiche.

"Publications of the Geological Survey, 1962-1970" may be purchased by mail and over the counter in paperback book form and as a set of microfiche.

"Publications of the Geological Survey, 1971-1981" may be purchased by mail and over the counter in paperback book form (two volumes, publications listing and index) and as a set of microfiche.

Supplements for 1982, 1983, 1984, 1985, 1986, and for subsequent years since the last permanent catalog may be purchased by mail and over the counter in paperback book form.

State catalogs, "List of U.S. Geological Survey Geologic and Water-Supply Reports and Maps For (State)," may be purchased by mail and over the counter in paperback booklet form only.

"Price and Availability List of U.S. Geological Survey Publications," issued annually, is available free of charge in paperback booklet form only.

Selected copies of a monthly catalog "New Publications of the U.S. Geological Survey" are available free of charge by mail or may be obtained over the counter in paperback booklet form only. Those wishing a free subscription to the monthly catalog "New Publications of the U.S. Geological Survey" should write to the U.S. Geological Survey, 582 National Center, Reston, VA 22092.

Note.--Prices of Government publications listed in older catalogs, announcements, and publications may be incorrect. Therefore, the prices charged may differ from the prices in catalogs, announcements, and publications. 


\section{Geohydrology of the}

\section{Ozark Plateaus Aquifer System}

in Parts of Missouri, Arkansas,

Oklahoma, and Kansas

By J.L. IMES and L.F. EMMETT

REGIONAL AQUIFER-SYSTEM ANALYSIS-CENTRAL MIDWEST

U.S. GEOLOGICAL SURVEY PROFESSIONAL PAPER 1414-D

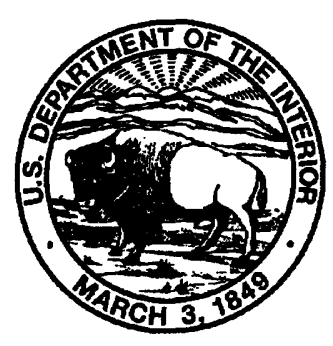




\title{
U.S. DEPARTMENT OF THE INTERIOR \\ BRUCE BABBITT, Secretary
}

\section{U.S. GEOLOGICAL SURVEY}

Robert M. Hirsch, Acting Director

\begin{abstract}
Any use of trade, product, or firm names in this publication is for descriptive purposes only and does not imply endorsement by the U.S. Government
\end{abstract}

\section{Library of Congress Cataloging-in-Publication Data}

Imes, Jeffrey L.

Geohydrology of the Ozark Plateaus aquifer system in parts of Missouri, Arkansas, Oklahoma, and Kansas / by J.L. Imes and L.F. Emmett. 1414-D)

p. cm. - (Regional aquifer-system analysis-Central Midwest) (U.S. Geological Survey professional paper ;

Includes bibliographical references.

1. Aquifers-Ozark Mountains. I. Emmett, Leo F. II. Title. III. Series. IV. Series: U.S. Geological Survey professional paper ; 1414-D.

GB1199.3.09I44 1993

$551.49^{\prime} 09767 ' 1-\mathrm{dc} 20$

93-37490

CIP

For sale by U.S. Geological Survey, Map Distribution,

Box 25286, MS 306, Federal Center, Denver, CO 80225 


\section{FOREWORD}

\section{THE REGIONAL AQUIFER-SYSTEM ANALYSIS PROGRAM}

The Regional Aquifer-System Analysis (RASA) Program was started in 1978 following a congressional mandate to develop quantitative appraisals of the major ground-water systems of the United States. The RASA Program represents a systematic effort to study a number of the Nation's most important aquifer systems, which in aggregate underlie much of the country and which represent an important component of the Nation's total water supply. In general, the boundaries of these studies are identified by the hydrologic extent of each system and accordingly transcend the political subdivisions to which investigations have often arbitrarily been limited in the past. The broad objective for each study is to assemble geologic, hydrologic, and geochemical information, to analyze and develop an understanding of the system, and to develop predictive capabilities that will contribute to the effective management of the system. The use of computer simulation is an important element of the RASA studies, both to develop an understanding of the natural, undisturbed hydrologic system and the changes brought about in it by human activities, and to provide a means of predicting the regional effects of future pumping or other stresses.

The final interpretive results of the RASA Program are presented in a series of U.S. Geological Survey Professional Papers that describe the geology, hydrology, and geochemistry of each regional aquifer system. Each study within the RASA Program is assigned a single Professional Paper number, and where the volume of interpretive material warrants, separate topical chapters that consider the principal elements of the investigation may be published. The series of RASA interpretive reports begins with Professional Paper 1400 and thereafter will continue in numerical sequence as the interpretive products of subsequent studies become available.

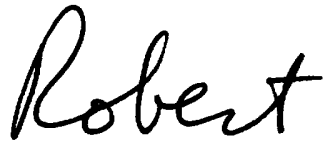

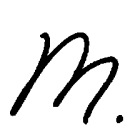

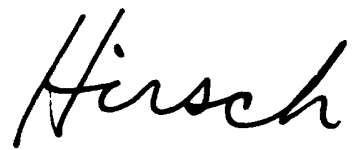

Robert M. Hirsch

Acting Director 



\section{CONTENTS}

Abstract-

Introduction

Purpose and scope

Description of study area-

Previous investigations

Acknowledgments

Physiography and geology of the Ozark Plateaus province and adjacent parts of the Interior Plains and Arkansas Valley

Physiographic features -.

Tectonic activity and depositional history

Ground-water flow and geohydrologic properties of the

Ozark area

Regional geohydrologic units -

Basement confining unit

Configuration of the upper surface ---.--.

Lithology and permeability

St. Francois aquifer

Structural features-

Thickness -

Lithology and geohydrologic properties --.-...-.--

Recharge, ground-water flow, and discharge ----

Chemical quality of ground water

St. Francois confining unit

Structural features

Thickness

Lithology and geohydrologic properties

Ozark aquifer

Structural features

Thickness

Lithology and geohydrologic properties --.--.--.-Recharge, ground-water flow, and discharge ---Chemical quality of ground water

Ozark confining unit-

Structural features

Thickness
Ground-water flow and geohydrologic properties of the

Ozark area-Continued

Regional geohydrologic units-Continued

Ozark confining unit-Continued

Lithology and geohydrologic properties -._-_._. D60

Springfield Plateau aquifer -._- 63

Structural features-1- 63

Thickness--_- 63

Lithology and geohydrologic properties _.........- 63

Recharge, ground-water flow, and discharge --- $\quad 67$

Chemical quality of ground water -_.- 69

Western Interior Plains confining system -..-......- $\quad 74$

Structural features-_-_- 74

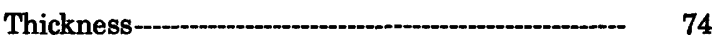

Lithology and geohydrologic properties -.-.-... $\quad 77$

Lateral ground-water movement in the nearsurface weathered zone of the Western Interior Plains confining system --:- 77

Unnamed local geohydrologic units -_._- $\quad 78$

Post-Paleozoic deposits -.-_-_-_-_- 82

Interaction of surface and ground water: Recharge to the regional ground-water flow system -..-_-_-_-_-_-_-_-_-- 83

Estimates of recharge and discharge -...-_._-_._-_._-_._- $\quad 87$

Model simulation of predevelopment ground-water flow -...-. $\quad 90$

Boundary conditions on lateral ground-water flow --..-- 91

Boundary conditions and leakage coefficients governing vertical ground-water flow

Boundary conditions associated with recharge and discharge of ground water

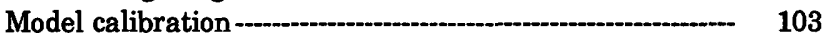

Magnitude and distribution of hydraulic properties

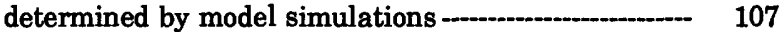

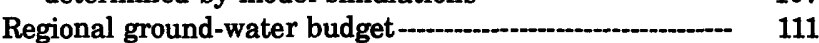

Availability and use of ground water and well yields --..-..-- 117

Summary and conclusions -......-. 121

Selected references -

\section{ILLUSTRATIONS}

Figures 1-10. Maps showing:

1. Central Midwest Regional Aquifer-System Analysis study area -

2. Location of study area

3. Approximate boundary of the Ozark Plateaus aquifer system

4. Mean annual precipitation in and adjacent to study area from 1951 to 1980

5. Physiographic subdivisions of the Ozark Plateaus and adjacent areas

6. Large rivers and streams within and bordering study area

7. Thickness of Paleozoic sedimentary rocks in study area-

8. Structural features of the midcontinent-

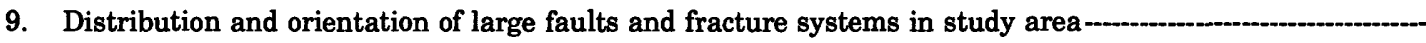

10. Generalized flow of ground water in deeper units of the Ozark Plateaus aquifer system -...-...-...-

11. Schematic cross section of regional geohydrologic units in and adjacent to the Ozark Plateaus aquifer system --12-15. Maps showing:

12. Outcrop areas of regional geohydrologic units in and adjacent to the Ozark Plateaus province -._._.

13. Areal extent and configuration of top of the Basement confining unit

14. Depth of the St. Francois aquifer below land surface-1

15. Areal extent and configuration of top of the St. Francois aquifer 
Figures 16-50. Maps showing:

16. Thickness of the St. Francois aquifer

17. Predevelopment potentiometric surface of the St. Francois aquifer-

18. Water type in the St. Francois aquifer-

19. Dissolved-solids, chloride, and sulfate concentrations in ground water from the St. Francois aquifer-------

20. Areal extent and configuration of top of the St. Francois confining unit--

21. Thickness of the St. Francois confining unit -

22. Shale content of the St. Francois confining unit--

23. Net shale thickness in the St. Francois confining unit

24. Depth of the Ozark aquifer below land surface -

25. Areal extent and configuration of top of the Ozark aquifer

26. Thickness of the Ozark aquifer

27. Distribution of hydraulic conductivity of the Ozark aquifer

28. Predevelopment potentiometric surface of the Ozark aquifer

29. Water type in the Ozark aquifer

30. Dissolved-solids concentrations in ground water from the Ozark aquifer-

31. Chloride concentrations in ground water from the Ozark aquifer-

32. Sulfate concentrations in ground water from the Ozark aquifer-

33. Areal extent and configuration of top of the Ozark confining unit

34. Thickness of the Ozark confining unit -

35. Shale content of the Ozark confining unit -

36. Net shale thickness in the Ozark confining unit -

37. Depth of the Springfield Plateau aquifer below land surface

38. Areal extent and configuration of top of the Springfield Plateau aquifer -

39. Thickness of the Springfield Plateau aquifer

40. Predevelopment potentiometric surface of the Springfield Plateau aquifer -.._.

41. Water type in the Springfield Plateau aquifer-

42. Dissolved-solids concentrations in ground water from the Springfield Plateau aquifer --

43. Chloride concentrations in ground water from the Springfield Plateau aquifer

44. Sulfate concentrations in ground water from the Springfield Plateau aquifer

45. Altitude of top of the Western Interior Plains confining system -

46. Thickness of the Western Interior Plains confining system-

47. Predevelopment potentiometric surface of near-surface weathered zone of the Western Interior Plains confining system

48. Location of unnamed local geohydrologic units in northeastern part of the Ozark Plateaus province --...-

49. Altitude of top, thickness, and potentiometric surface of rocks in area B (fig. 48) that are stratigraphically equivalent to the Springfield Plateau aquifer-

50. Altitude of top, thickness, and potentiometric surface of rocks in area C (fig. 48) that are stratigraphically equivalent to the Springfield Plateau aquifer-

51. Schematic diagram of surface- and ground-water exchange mechanisms in the Ozark Plateaus province--.-.-...-...-

52. Map showing distribution of primary and secondary karst areas in the Ozark Plateaus province--

53. Graph showing effect of precipitation on water levels in observation well in Phelps County, Missouri --..--.-.-.

54. Graph showing effect of precipitation on water levels in observation well in Howell County, Missouri --..-...-..-

55-61. Maps showing:

55. Selected springs of the Ozark Plateaus province -

56. Estimated recharge to water table

57. Area represented by ground-water flow model of the Ozark Plateaus aquifer system, showing orientation and numbering of finite-difference grid -.

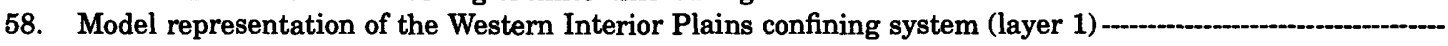

59. Model representation of the Springfield Plateau aquifer and post-Paleozoic sediments (layer 2)-_............

60. Model representation of the Ozark aquifer (layer 3) -

61. Model representation of the St. Francois aquifer (layer 4)

62. Plan view of hypothetical model cells showing areas of intracell and intercell ground-water flow

63. Cross section of two hypothetical model cells showing recharge contributions to ground-water flow within model cells and between model cells

64 Plan view showing method of distributing regional base flow to model cells

65. Graph showing sensitivity of model layers 2 and 3 to selected changes in hydraulic properties-a...66-67. Maps showing:

66. Recharge to water table as estimated by Dugan and Peckenpaugh (1986) and redistributed recharge to account for ground water that remains internal to a model cell

67. Distribution of vertical hydraulic conductivity and leakage coefficient for model layer 1 , representing leakage through the Western Interior Plains confining system 
Figures 68-72. Maps showing:

68. Distribution of lateral hydraulic conductivity and transmissivity for model layer 2, representing the

Springfield Plateau aquifer and Cretaceous sands of the Mississippi Embayment--.-. Distribution of vertical hydraulic conductivity and leakage coefficient between the Springfield Plateau
69. and Ozark aquifers and between Cretaceous sand and the Ozark aquifer-

70. Distribution of lateral hydraulic conductivity and transmissivity for model layer 3 , representing the Ozark aquifer

71. Distribution of vertical hydraulic conductivity and leakage coefficient between the Ozark and St. Francois aquifers

72. Distribution of lateral hydraulic conductivity and transmissivity for model layer 4, representing the St. Francois aquifer

73. Diagram showing regional ground-water budget of the Ozark Plateaus aquifer system based on simulation --..---

74. Map showing estimated average daily withdrawal of ground water by county from the Ozark Plateaus

aquifer system and the Western Interior Plains confining system during 1970-1979

\section{TABLES}

TABLE 1. Generalized correlation of Paleozoic stratigraphic units and regional geohydrologic units in study area

2. Explanation of symbols used in maps of major chemical constituents

3. Water budgets for the Ozark Plateaus aquifer system

\section{CONVERSION FACTORS AND VERTICAL DATUM}

For readers who wish to convert measurements from the inch-pound system of units to the metric system of units, the conversion factors are listed below:

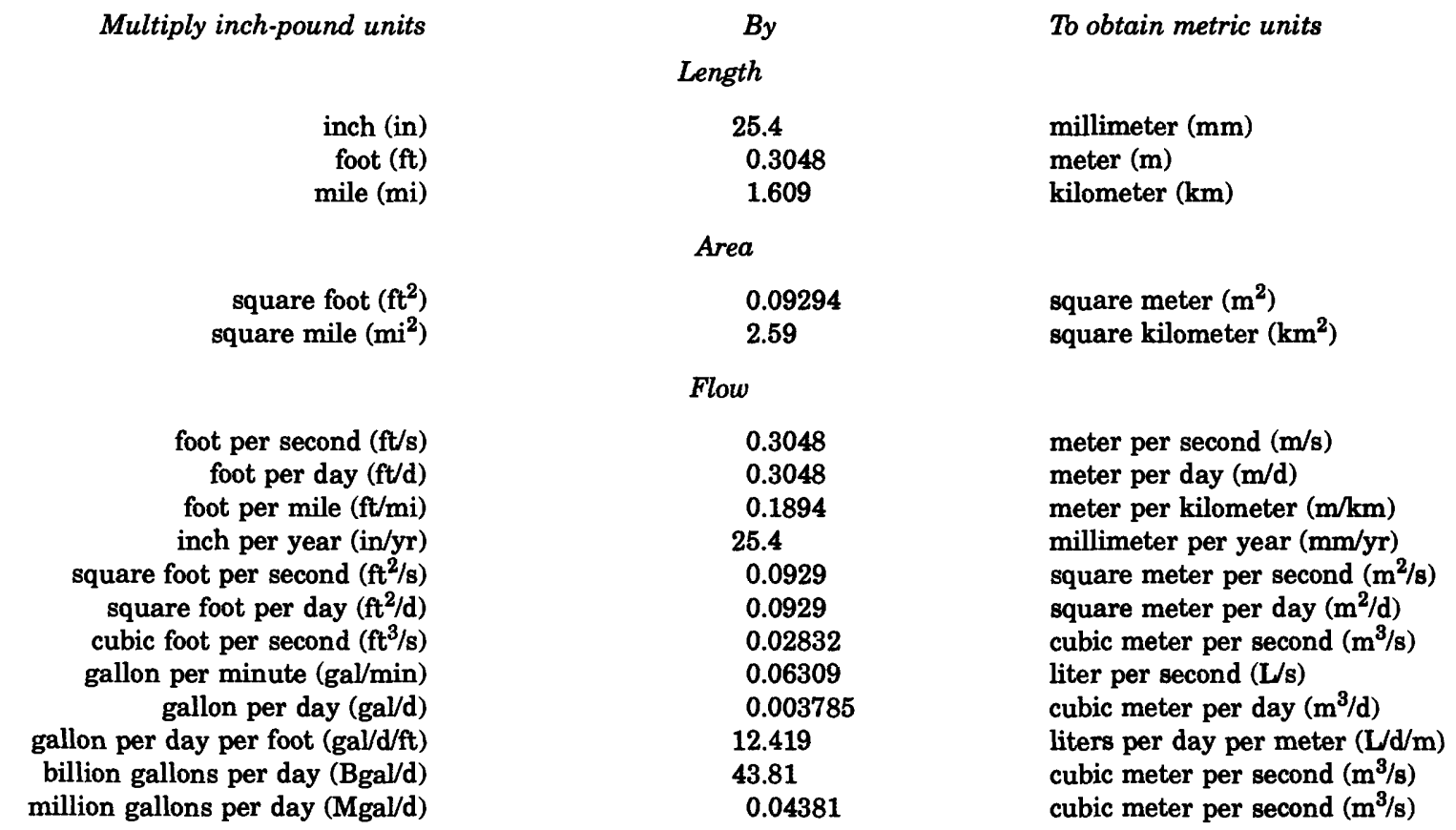

To convert temperature in ${ }^{\circ} \mathrm{F}$ (degrees Fahrenheit) to ${ }^{\circ} \mathrm{C}$ (degrees Celsius) subtract 32 and multiply by 1.8 .

Sea level: In this report, "sea level" refers to the National Geodetic Vertical Datum of 1929 (NGVD of 1929)-a geodetic datum derived from a general adjustment of the first-order leveling nets of both the United States and Canada, formerly called Sea Level Datum of 1929. 



\title{
GEOHYDROLOGY OF THE OZARK PLATEAUS AQUIFER SYSTEM IN PARTS OF MISSOURI, ARKANSAS, OKLAHOMA, AND KANSAS
}

\author{
By J.L. IMES and L.F. EMMETT
}

\begin{abstract}
The Ozark Plateaus aquifer system consists of Paleozoic sedimentary rocks that overlie Precambrian igneous rocks designated the Basement confining unit. Geohydrologic units of the Ozark Plateaus aquifer system are designated from the stratigraphically lowest to highest: the St. Francois aquifer, the St. Francois confining unit, the Ozark aquifer, the Ozark confining unit, and the Springfield Plateau aquifer. The Ozark Plateaus aquifer system is stratigraphically equivalent and laterally adjacent to the Western Interior Plains aquifer system, which extends west from the study area to the Rocky Mountains. The Western Interior Plains confining system confines the Ozark Plateaus aquifer system along the western and southern boundaries of the study area and also was studied as part of this investigation. Maps are presented depicting the areal extent, thickness, and upper surface of each geohydrologic unit and the predevelopment potentiometric surface of the aquifers. Maps also were prepared showing water type and concentrations of dissolved solids, chloride, and sulfate in water from each aquifer on the basis of available chemical analyses. Potential well yields from each aquifer and lithologic descriptions of each geohydrologic unit are presented as indicators of the relative permeability of the confining units and the aquifers.

The mainly freshwater Ozark Plateaus aquifer system is almost entirely surrounded by and hydraulically isolated from saline ground-water flow systems. The northern boundary and discharge area for the Ozark Plateaus aquifer system is the Missouri River alluvial valley. The eastern boundary is the Mississippi River alluvial valley from its confluence with the Missouri River southward to the Mississippi Alluvial Plain, which forms the southeast boundary. The southern boundary of the aquifer system is approximately parallel to the Arkansas River valley. The western boundary of the aquifer system is a complex transition zone where freshwater flows westward from the Ozark Plateaus and mixes with salinewater flowing eastward through the Western Interior Plains aquifer system.

A three-dimensional finite-difference model was used to simulate regional ground-water flow in the Ozark Plateaus aquifer system under predevelopment conditions. Local flow, mostly recharge that discharges to nearby streams in aquifer outcrop areas, was excluded from the simulation. Differentiation between "local" and "regional" recharge was based primarily on analysis of base flow of streams and topographic factors. Estimated total ground-water recharge to regional and local systems is about 25 percent of precipitation; however, simulated recharge to just the regional flow system averages about 22 percent of the total recharge (or 6 per-
\end{abstract}

cent of precipitation) throughout the modeled area. The simulation of predevelopment conditions suggests that inflow to the regional ground-water flow system was about 7,000 cubic feet per second. Outflow consisted of about 4,000 cubic feet per second discharging to streams and springs in the study area and about 3,000 cubic feet per second discharging as boundary flow to the Mississippi, Neosho, Missouri, and Arkansas Rivers, the aquifers of the Mississippi Embayment, and the water table in the overlying Western Interior Plains confining system. Present-day rates of inflow and outflow are probably similar inasmuch as current (1987) withdrawals of ground water are comparatively small (about 300 cubic feet per second).

The steady-state model calibration yielded estimates of the lateral hydraulic conductivity of the St. Francois, Ozark, and Springfield Plateau aquifers. The lateral hydraulic conductivity of the St. Francois aquifer ranges from $1.6 \times 10^{-4}$ foot per second near the St. Francois Mountains to $8.0 \times 10^{-5}$ foot per second elsewhere. The lateral hydraulic conductivity of the Ozark aquifer ranges from $1.0 \times 10^{-5}$ foot per second in the south to $8.0 \times 10^{-4}$ foot per second in the north and east. The lateral hydraulic conductivity of the Springfield Plateau aquifer is about $2.5 \times 10^{-4}$ foot per second.

Dissolved-solids concentration in the generally calcium magnesium bicarbonate water of the Ozark aquifer and the generally calcium bicarbonate water of the Springfield Plateau aquifer ranges from 200 milligrams per liter where the aquifers crop out to greater than 2,000 milligrams per liter near the western boundary of the aquifers.

Approximately 200 million gallons per day of ground water are withdrawn from the Ozark Plateaus aquifer system by large-yield public-supply, industrial, and irrigation wells in the Ozark Plateaus province and adjacent areas.

\section{INTRODUCTION}

Regional Aquifer-System Analysis (RASA) programs have been developed by the U.S. Geological Survey "to provide an understanding of existing ground-water flow system and water-quality distributions on a regional scale, to provide predictive capabilities through which the consequences of development can be evaluated, again on a regional scale, and to provide a framework for more detailed local investigations." (Bennett, 1979, p. 42.) Regional aquifer studies are 
underway or have been completed in five large areas within the central United States (Sun, 1986). These studies (fig. 1) are the Central Midwest Regional Aquifer-System Analysis (CMRASA) as described by Jorgensen and Signor (1981), the Northern Midwest Regional Aquifer-System Analysis as described by Steinhilber and Young (1979), the Gulf Coast Regional Aquifer-System Analysis as described by Grubb (1984), the Northern Great Plains Regional AquiferSystem Analysis as described by Dinwiddie (1979), and the High Plains Regional Aquifer-System Analysis as described by Weeks (1978).

The geohydrology of the Ozark Plateaus province (synonymous with the term "Ozarks" in this report) and of adjacent parts of the Interior Plains and Ar- kansas Valley was studied as part of the Central Midwest Regional Aquifer-System Analysis (CMRASA). The CMRASA study focused on a regionally significant source of ground water and geohydrologic units that confine or otherwise affect the hydrology of the regional aquifer system. The Ozark Plateaus aquifer system was chosen for a more detailed geohydrologic study because it is a predominantly freshwater system that is almost entirely surrounded by, but hydraulically isolated from, neighboring saline groundwater flow systems. The mainly carbonate rocks of the Ozark Plateaus are the source of freshwater for most public water users and for virtually all self-supplied domestic water users in the area. The carbonate rocks that constitute the aquifer system contain extensive

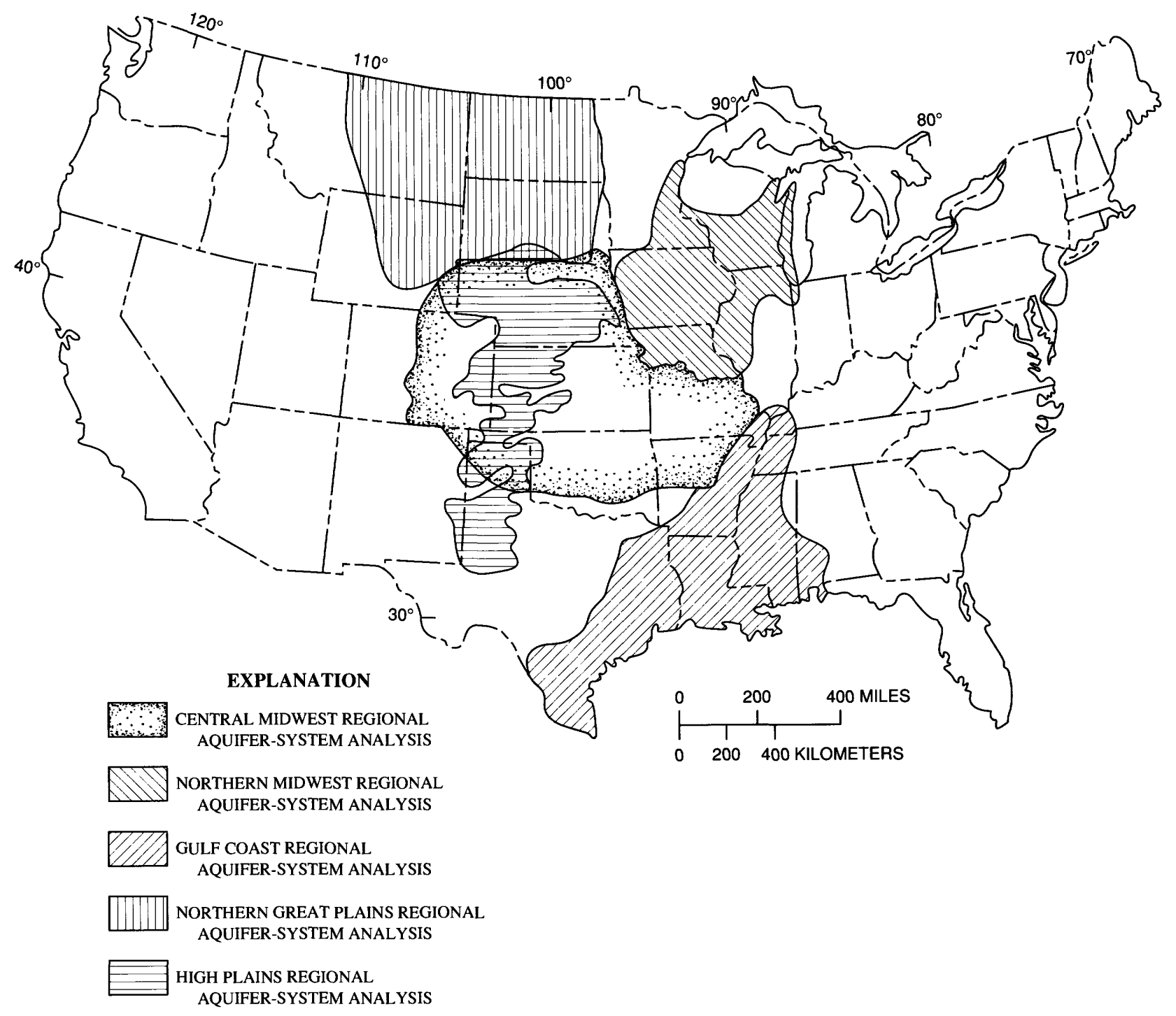

Figure 1.-Central Midwest Regional Aquifer-System Analysis study area and adjacent Regional Aquifer-System Analysis study areas. 
areas of karst, which render the Ozark Plateaus aquifer system susceptible to ground-water contamination. Consequently, care needs to be used in construction of wells and in disposal of wastes to protect the ground-water resources in the aquifer area.

Because the Ozark area is located within a humid climatic zone and contains an extensive region of karst terrane and a well-developed network of solution channels, the area contains one of the largest concentrations of springs in the United States. Thousands of springs scattered across the Ozarks yield from less than a gallon to millions of gallons of water per day. The combined flow of the ten largest springs is about 2,000 cubic feet per second ( 1.3 billion gallons per day). Springs, large and small, were important to the early settlement of the Ozarks because they served as domestic and stock-water supplies, powered grist mills, provided salt (from mineralized springs in and around Saline County Missouri), were developed into health spas because of their supposed medicinal qualities, and were used as a refrigerant as evidenced by the many springhouses that still exist in the Ozarks. Currently (1987) the springs also provide water for trout and bass hatcheries and water for recreational use.

Because of the extensive network of solution channels and conduits in the highly karstic carbonate rocks, ground water may be easily contaminated in this area. Surface contaminants are quickly transported from recharge areas and intercepted by wells or concentrated at spring discharge sites. The sources of contamination often are unexpected. For example, in 1978 a sinkhole collapse occurred in a municipal sewage lagoon at West Plains, a small town in the south-central Ozarks. Several days later, Mammoth Springs, located 36 miles southeast of West Plains, began showing evidence of raw-sewage contamination. Before the collapse it was not known that the catchment area of Mammoth Springs extended to the vicinity of West Plains. In the northeastern part of the Ozarks, a liquid-fertilizer pipeline ruptured 13 miles west of Maramec Spring in the Dry Fork River valley (Vandike, 1981). Rare cave fauna and thousands of trout were killed at the spring orifice. These events emphasize the susceptibility of the Ozarks ground-water system to contamination.

Also of concern is the contamination of ground water in the Ozarks on a regional scale by effluent from private septic tanks and sewage lagoons, livestock wastes, agricultural pesticides and fertilizers, and authorized and unauthorized landfills. Chemical analysis of spring waters in upper reaches of the White River drainage basin indicates nitrate concentrations 13 times larger than in springs of the Cur- rent River basin to the east (Barks, 1978). The larger concentrations are attributed to greater densities of population and livestock. Ground water beneath towns and cities may be contaminated by leakage of gasoline and fuel oil from corroded underground storage tanks. Gasoline and other volatile organic compounds already have been discovered in domestic wells in and near several cities in Missouri.

These problems, and the potential for more serious problems as a growing population places increasing demands upon the ground-water system, indicate the need for a comprehensive investigation of the invaluable freshwater resources of the Ozark Plateaus. This report describes regional factors that control ground-water flow in the Ozarks and identifies the major geohydrologic units through which the ground water moves.

\section{PURPOSE AND SCOPE}

The purpose of the Central Midwest RASA is to assess the ground-water resources contained in the regional aquifers of the study area and to provide an improved understanding of the flow of water, quality of water, and hydraulic properties of rocks in the regional aquifer system in order to permit a better evaluation of available ground-water resources. To accomplish the purpose of the Central Midwest RASA for the Ozark Plateaus aquifer system, several objectives were set and accomplished. The objectives of the study described in this report were the following:

1. Identify the major geohydrologic units of the Ozarks and describe their lithologic and geologic characteristics, especially those characteristics that affect the movement of ground water.

2. Describe the flow of water in each of the identified aquifers (including areas of recharge and discharge) and the restriction of ground-water flow by the confining units.

3. Describe the background chemical composition of water in the Ozark Plateaus aquifer system.

4. Describe the current (1987) use and availability of water in the Ozark Plateaus aquifer system.

5. Construct a digital ground-water flow model of the Ozark Plateaus aquifer system to analyze current concepts about water flow in the aquifer system, recharge to the system, relative transmissivity of geohydrologic units in the system, and boundary conditions imposed on the system.

The Ozark Plateaus aquifer system is confined along its western and southern border by the Western Interior Plains confining system, a major geohydrologic unit that stretches west to the Rocky 
Mountains (Jorgensen and others, 1993). Because the Western Interior Plains confining system has major effects on the Ozark Plateaus aquifer system, the confining system is also discussed in this report. Similarly, the geohydrologic characteristics of postPaleozoic deposits that blanket the southeast flank of the aquifer system are discussed. A more detailed description of the geohydrology of the post-Paleozoic deposits can be found in Luckey (1985) and Brahana and Mesko (1988). Several small, unnamed geohydrologic units that overlie the Ozark Plateaus aquifer system in the northeast part of the Ozark Plateaus are briefly discussed.

\section{DESCRIPTION OF STUDY AREA}

The Central Midwest RASA study area extends from the foothills of the Rocky Mountains in Colorado to the Mississippi River in eastern Missouri and, generally, from South Dakota to Texas (fig. 1). This report provides a more comprehensive description of the Ozark Plateaus aquifer system in the easternmost part of the Central Midwest RASA study area (fig. 2). The boundaries of the study area are approximately coincident with the natural flow boundaries of the Ozark Plateaus aquifer system. The area of investigation encompasses parts of four states: southern Missouri, southeastern Kansas, northeastern Oklahoma, and northern Arkansas. The study area is approximately 65,500 square miles, or about 18 percent of the larger Central Midwest RASA area.

The approximate boundary of the Ozark Plateaus aquifer system and counties and selected towns within the States that contain the aquifer system are shown in figure 3 . The study area is bounded by the Missouri River to the north, the Arkansas River to the south, the Mississippi River to the east, and the Neosho River to the southwest.

Geologic strata included in the Ozark Plateaus aquifer system extend beyond the boundaries of the study area and constitute geohydrologic units in these neighboring regions that are stratigraphically equivalent to the Ozark Plateaus aquifer system. Some of these units have been or currently (1987) are being studied as part of the Northern Midwest RASA, the Central Midwest RASA, and the Gulf Coast RASA. Refer to Emmett and Imes (1984) and Imes (1985) for studies of those units north of the Ozarks, Jorgensen and others (1993) for studies of those units west and south of the Ozarks, and Brahana and Mesko (1988) for studies of those units southeast of the Ozarks.
Rainfall in the study area normally is abundant and fairly well distributed throughout the year; mean monthly precipitation ranges from about 2 inches in January to about 4 inches in June. However, extended periods of no rain and periods of flooding are not unusual. Mean annual precipitation in the Ozarks (Hedman and others, 1987) generally increases to the southeast and varies from 36 inches per year in the north, near the Missouri River, to 50 inches per year in the extreme south, where the Arkansas River flows out of the study area (fig. 4). Precipitation during the cool season (October to April) replenishes soil moisture lost during the warm season (May to September) when consumptive water requirements are largest. Excess soil moisture and, consequently, ground-water recharge are most likely to occur during the cool season.

\section{PREVIOUS INVESTIGATIONS}

Information about well construction, water levels, and chemical quality of water from wells drilled in the study area in the late 19th and early 20th centuries has been published in U.S. Geological Survey Water-Supply Papers (Darton, 1905; Shepard, 1904, 1907). Additional data about the occurrence, availability, use, and chemical quality of ground water in the study area have been published in various State and Federal publications. These studies were made by various State agencies, often in cooperation with the U.S. Geological Survey, and generally encompassed one or more counties in a State. For example, Reed and others (1955), in a study of the groundwater resources of Ottawa County, Oklahoma, documented a 200- to 300-foot decline in water levels in wells open to Lower Ordovician rocks (Roubidoux Formation and Gasconade Dolomite). Water levels declined more than $\mathbf{4 0 0}$ feet in the vicinity of Miami, Oklahoma (fig. 3), from 1900 to 1950. When wells first tapped the Lower Ordovician rocks in Oklahoma in about 1900 , the artesian pressure was sufficient to make them flow (Reed and others, 1955, p. 10). Three aquifer tests were made in 1944 on deep wells $(1,055 \mathrm{ft}$ to $1,235 \mathrm{ft})$ open to the Roubidoux Formation. Analysis of the data gave an average transmissivity of 5,080 feet squared per day (38,100 gallons per day per foot) and an average coefficient of storage of $8 \times 10^{-5}$ (Reed and others, 1955, p. 104). Stramel (1957) documented a decline in water level from 1882 to 1954 of about 110 feet in the Pittsburg, Kansas, well field. Use of water from the well field averaged 1.4 million gallons per day during that period. 
Feder and others (1969) appraised the water resources in the Joplin, Missouri, area. They defined two geohydrologic units: a shallow aquifer principally composed of limestone of Mississippian age and a deep aquifer principally composed of dolomite and small quantities of sandstone of Ordovician and Cambrian age. The two aquifers are separated by a leaky confining unit consisting of Lower Mississippian and Upper Devonian silty limestone and shale. They noted that in the eastern part of the area, the potentiometric surface of the deep aquifer is 50 to 100 feet below the potentiometric surface of the shallow aquifer, and in the west the head difference increases to as much as 180 feet.

Saline County, Missouri (fig. 3), straddles the transition between the fresh ground water of the Ozarks and the saline ground water of northwestern Missouri. A study of the ground-water resources of Saline County (Miller, 1971) noted that salinewater (dissolved-solids concentration greater than 1,000 $\mathrm{mg} / \mathrm{L}$ ) occurs in the troughs between anticlinal structures, and freshwater (dissolved-solids concentration less than $1,000 \mathrm{mg} / \mathrm{L}$ ) occurs along the crests and flanks of these structures. Miller described the saline ground water in Saline County as a connate water that probably had its origin either by entrapment of seawater in marine sediments or by shale membrane filtration of more dilute waters.

Lamonds (1972) provided information on the occurrence, availability, and chemical quality of surface water and ground water for the Ozark Plateaus province in northern Arkansas. He identified the Gunter

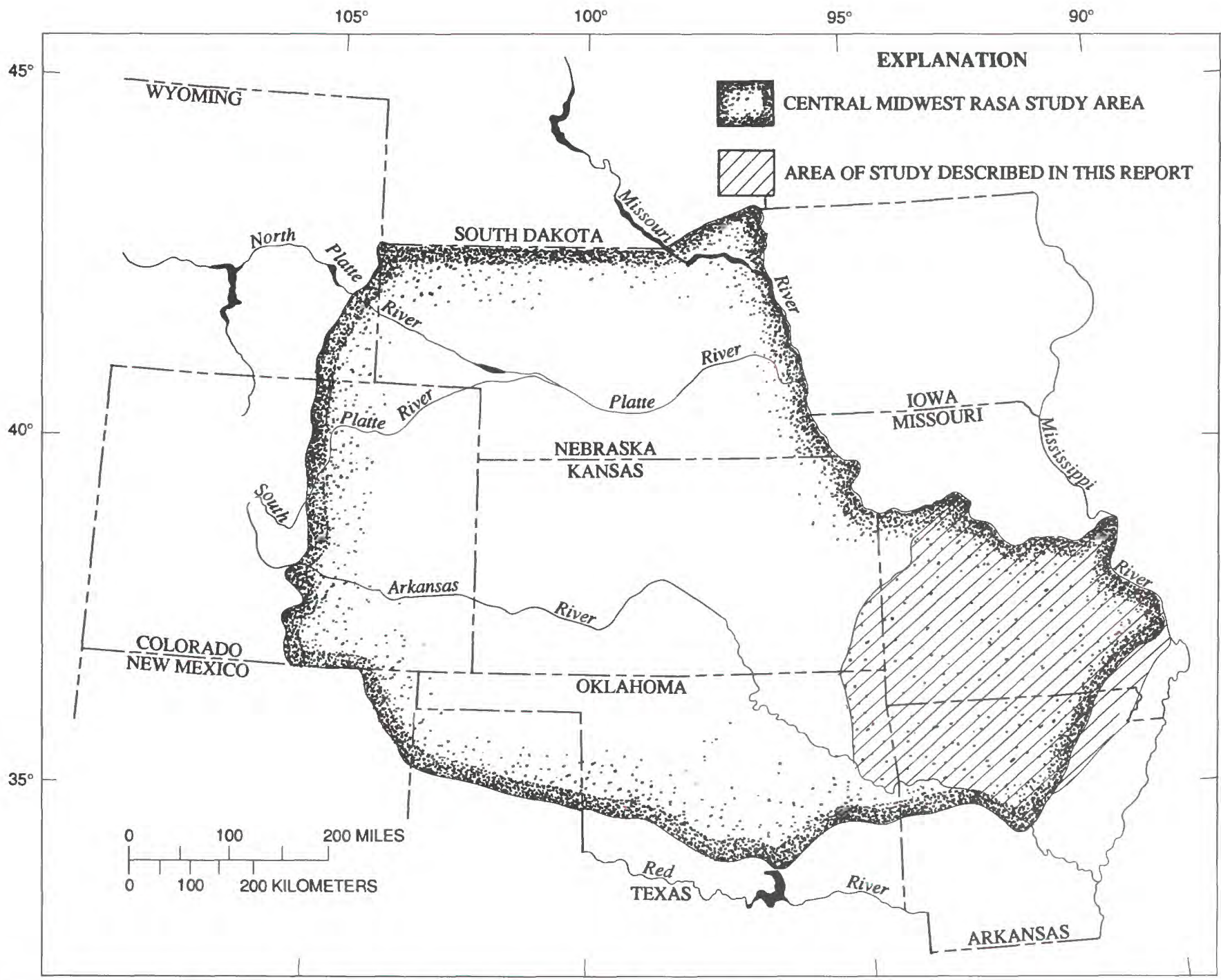

Figure 2.-Location of study area described in this report and larger Central Midwest Regional Aquifer-System Analysis (RASA) study area. 


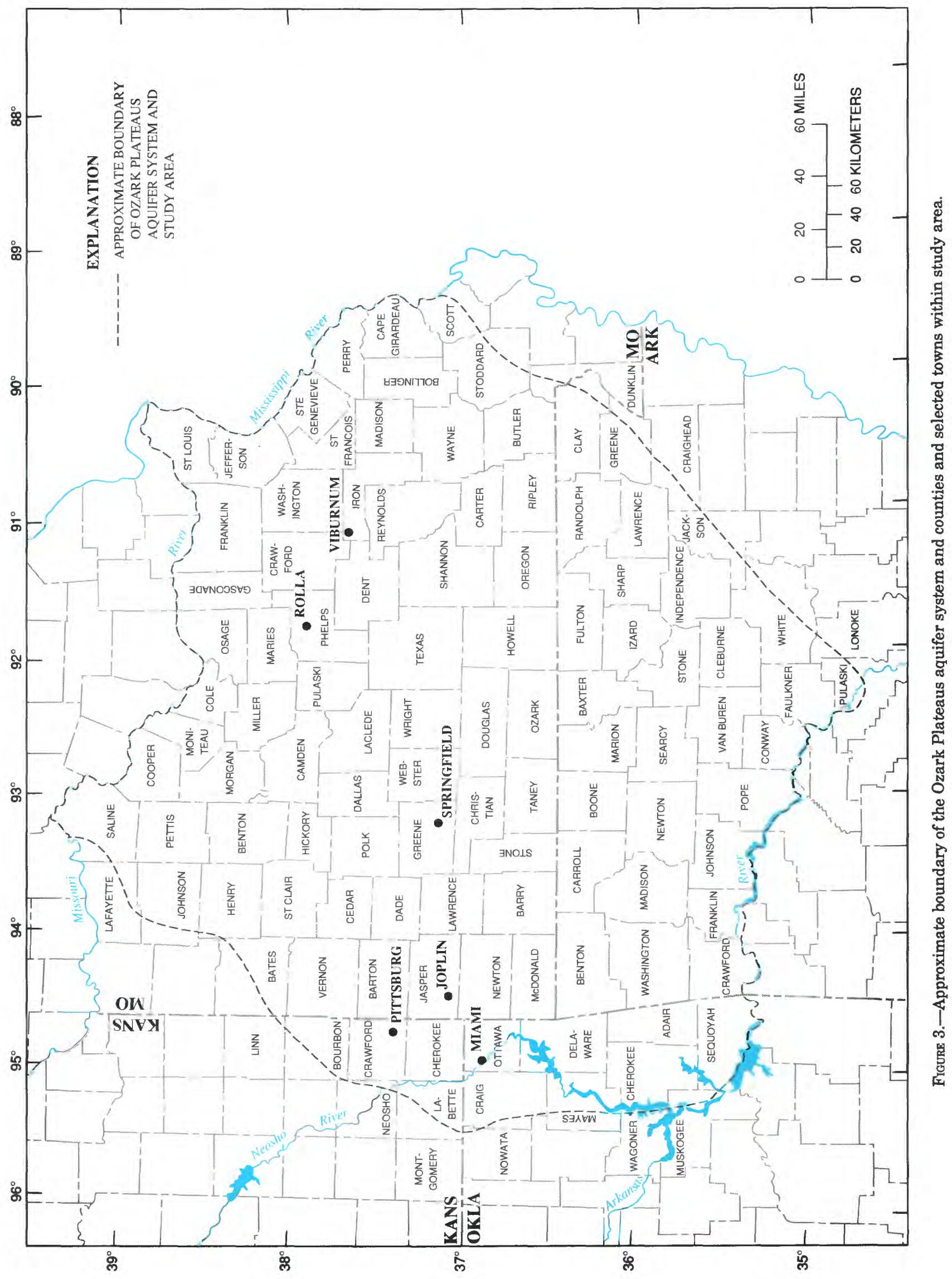




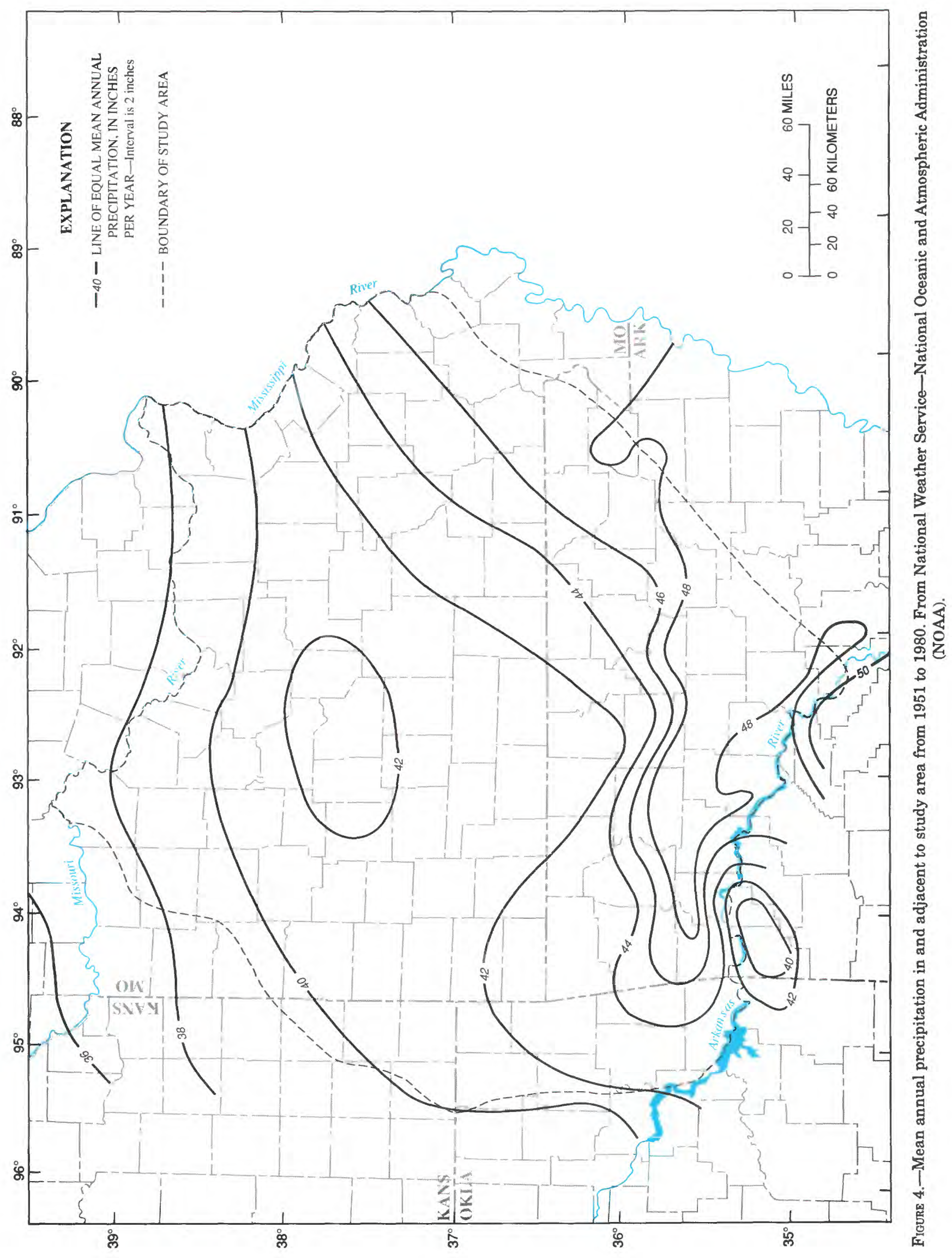


Sandstone Member of the Van Buren Formation and the Roubidoux Formation as the most productive water-bearing rocks in northern Arkansas.

Vineyard and Feder (1974) presented data for 585 Missouri springs, most of which discharge from dolomite rocks on the Salem Plateau. The principal geologic formations from which the springs flow are the Gasconade, Eminence, and Potosi Dolomites.

Gann and others $(1974,1976)$ presented a general summary of information about the occurrence, availability, use, and quality of water in Missouri south of the Missouri River and exclusive of the Mississippi Alluvial Plain. Included in the report on southcentral Missouri is a generalized map of the potentiometric surface in the aquifer consisting of Cambrian and Ordovician dolomitic rocks. Also included is a summary of ground-water tracer experiments.

Emmett and others (1978) described the water resources in the Springfield area in Missouri. Included in the report is a two-dimensional model of groundwater flow in Lower Ordovician and Upper Cambrian rocks. Drawdown after 50 years of pumping was predicted on the basis of a projected increased rate of withdrawal of 10 million gallons per day from existing wells.

Harvey (1980) presented a generalized summary of the hydrology of aquifers composed of Ordovician and Cambrian rocks in the Springfield-Salem Plateaus of southern Missouri and northern Arkansas. He described ground-water recharge in the Salem Plateau as primarily occurring in three ways: through losing streams, through sinkholes, and by infiltration in upland areas. Harvey (1980) also states that the rate at which ground water is pumped in the SpringfieldSalem Plateaus and contiguous areas $\left(200 \mathrm{ft}^{3} / \mathrm{s}\right)$ is about 5 percent of the total streamflow at the 80percent point on streamflow-duration curves for major streams.

Harvey and others (1983) presented hydrologic information on three basins in south-central Missouri. Emphasis was placed on distinguishing losing from gaining stream reaches and determining their relation to ground-water movement. The authors evaluated various methods used in defining gaining and losing streams. They concluded that the most important controlling factor on the hydrology of Ozark basins is the quantity and type of structural deformation imposed on the rocks.

Spruill (1984) evaluated water-resource problems related to abandoned lead and zinc mines in Cherokee County, Kansas (fig. 3) and adjacent areas in Missouri and Oklahoma. The mines are in rocks of Mississippian age, which form the shallow aquifer. Pumping from the underlying deep aquifer has low- ered the potentiometric surface in the deep aquifer and increased the potential for downward movement of water from the shallow aquifer. Spruill (1984) believes that drill holes open to both shallow and deep aquifers and abandoned wells with corroded or leaky casings present the greatest contamination hazard to water supplies in the deep aquifer.

Kleeschulte and others (1985) described the ground-water resources of a three-county area in western Missouri that straddles a freshwater-salinewater transition zone. The transition zone diagonally crosses the three counties and separates freshwater in the southeast from salinewater in the northwest. Kleeschulte and others $(1985$, p. 55) state that the position of the freshwater-salinewater transition zone has not substantially moved during recent years, but minor fluctuations in water quality occur along the zone.

\section{ACKNOWLEDGMENTS}

During any large multi-State study, such as the CMRASA, cooperation between the district offices of the U.S. Geological Survey is essential to the proper and efficient completion of the project. The authors thank district personnel in adjacent states for giving the extra effort necessary for the successful completion of this study. We especially thank Christi Hansen of the Kansas district for working with the Missouri district on the task of eliminating discrepancies between geohydrologic units at the Kansas and Missouri state boundaries. Thanks to Dave Freiwald and Gus Ludwig of the Arkansas district for many consultations regarding the conceptualization of ground-water flow in the Ozark Plateaus aquifer system in northern Arkansas. We thank Dave Freiwald for contributing to the sections of this report on physiography and geology, climate, and surface-water and ground-water interaction. We thank Scott Christenson and Gregg Adams of the Oklahoma district for discussion of concepts regarding the interaction of freshwater in the Ozark Plateaus aquifer system with salinewater flow systems west of the study area.

\section{PHYSIOGRAPHY AND GEOLOGY OF THE OZARK PLATEAUS PROVINCE AND ADJACENT PARTS OF THE INTERIOR PLAINS AND ARKANSAS VALLEY}

\section{PHYSIOGRAPHIC FEATURES}

The Ozark Plateaus province is a geologic uplift, or dome, that rises above surrounding lowlands. The 
physiographic province is subdivided into four sections: the Salem Plateau, the Springfield Plateau, the St. Francois Mountains, and the Boston Mountains (fig. 5; Fenneman, 1938). The topographic axis of the broad anticlinal fold that forms the nearly elliptical uplift stretches from the extreme northwestern corner of Arkansas to the St. Francois Mountains in southeast Missouri. Surface altitudes along the axis are highest in Wright and Iron Counties, Missouri (fig. 3), where altitudes exceed 1,700 feet, and generally range from 1,500 to 1,700 feet between the counties. The flanks of the province are steeper to the east where the plateau terminates abruptly near the Mississippi River (400-ft altitude) and less steep to the west where land-surface altitudes are about 600 to 800 feet at the eastern edge of the Interior Plains (fig. 5). In northern Arkansas the symmetry of the dome is broken by the Boston Mountains, a higher plateau that rises abruptly above the rest of the province to altitudes exceeding 2,000 feet.

The Salem Plateau generally coincides with that part of the Ozarks where Ordovician and Upper Cambrian rocks are exposed, and includes some isolated areas where younger rocks that once covered the plateau still remain. Along a major topographic ridge that parallels the axis of the Ozark uplift and extends from northeastern Oklahoma to the St. Francois Mountains in southeastern Missouri, the Salem Plateau is a relatively flat upland plain. Stream channels are not deeply incised, but solution features such as sinkholes indicate the presence of subsurface channel development. To the north and south away from the divide, the streams increase in size and in density and cut deeply into the plain. A welldissected topography is present throughout most of the remainder of the plateau except between the major river valleys where the flat uplands are remnants of the original plain.

The Springfield Plateau is a crescent-shaped area, open to the northeast, that borders the Salem Plateau and generally coincides with the area in which Mississippian rocks are exposed. The plateau surface is nearly coplanar with the bedding of the Mississippian rocks; however, the plateau is not a structural plain, as indicated by the presence of truncated structural features in the interior of the plateau. The plain is interrupted by isolated, low hills of Pennsylvanian rocks, evidence that the process of peneplanation was not completed. A factor contributing to the present-day relief on the plateau surface is dissolution of the soluble limestone that forms the plateau.

The St. Francois Mountains are remnants of more resistant Precambrian igneous peaks that were exposed when Cambrian sediments were stripped away.
The approximately 70 -square-mile region in southeastern Missouri is characterized by rounded peaks that have steep sides and are separated by broad, flat valleys. The highest point in the area, Taum Sauk Mountain, has an elevation of 1,772 feet. There is no general level that can be traced across the mountain range to reveal an ancient peneplain surface. The entire region probably was once a part of the Salem Plateau peneplain, which has an elevation of about 1,500 feet around the St. Francois Mountains. Later periods of uplift and renewed erosion have destroyed evidence of the original peneplain surface.

The Boston Mountains differ from the St. Francois Mountains in that they are composed entirely of the remnants of an ancient peneplain (Bretz, 1965). The Boston Mountains constitute a higher, east-westoriented plateau on the southern flank of the Ozark Plateaus province. The northern boundary of the Boston Mountains is an escarpment rising about 700 feet above the Springfield Plateau. The mountainous plateau is capped by a thick, resistant Pennsylvanian sandstone. Both the dip of the sandstone strata and the slope of the plateau horizon are to the south, but the horizon slope is less than the dip of the strata; consequently, younger Pennsylvanian rocks form the southern boundary of the plateau where it merges into hills of the Arkansas Valley.

The Arkansas Valley, a physiographic section located south of the Ozark Plateaus province (fig. 5), occupies the northern half of the Ouachita province. The Arkansas Valley is the southernmost physiographic division in the study area. The lowland is characterized by a series of east-west-trending, parallel folds created by lateral compression from the northwardmoving Ouachita Mountain thrust front. The closely spaced, tight folds along the Ouachita Mountains grade to less closely spaced, gentle folds along the Ozark Plateaus. Faulting in the Arkansas Valley is extensive, and the downthrown sides are commonly on the north. Erosion of the folds has produced a series of linear ridges and mesas separated by broad, flat valleys.

The northwestern edge of the study area includes part of the areally extensive Interior Plains physiographic province (Fenneman, 1938) that borders the western edge of the Ozark Plateaus province. The Interior Plains province is a plain of low relief characterized by a series of east-facing escarpments that indicate the presence of more resistant strata (usually limestone) in the surficial Pennsylvanian rocks. Local relief in the area adjacent to the Ozark Plateaus generally is less than 250 feet, the areas of greater relief occurring where major streams cut the 


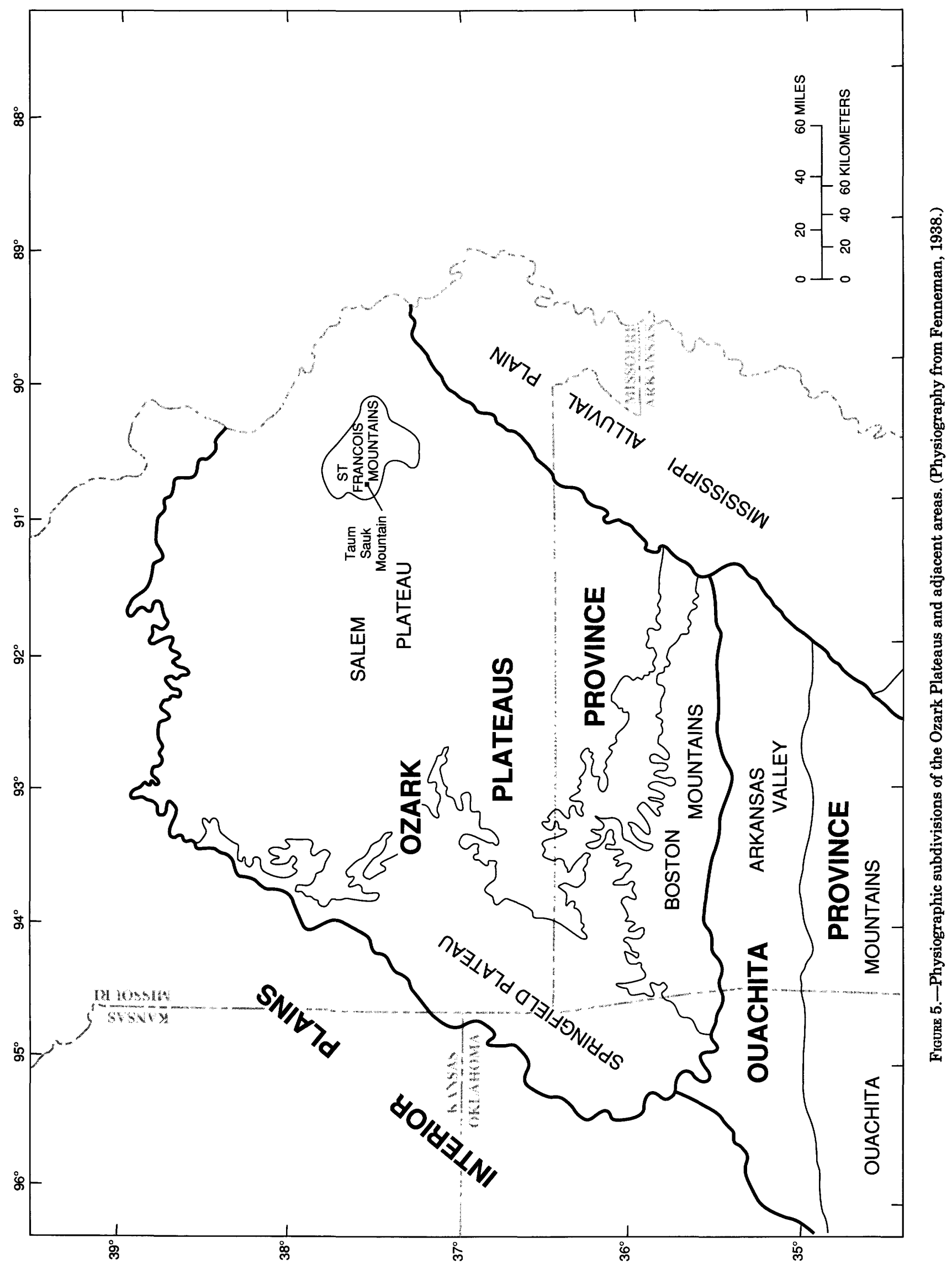


underlying rocks. In southeast Kansas a 25-milewide, distinctive belt of slightly rolling terrane that gradually merges into the Springfield Plateau defines the outcrop area of a thick, slightly consolidated, basal Pennsylvanian shale.

Much of the study area is bordered by alluvial valleys of the larger rivers of the midcontinental United States. The interior of the Ozark region contains many spring-fed rivers and large streams. Three continental rivers border parts of the study area (fig. 6): the Missouri River to the north, the Mississippi River to the east, and the Arkansas River to the south. The Neosho River of Kansas and Oklahoma forms a segment of the southwestern border of the study area. A major drainage system, the Marais des Cygnes and Osage Rivers and their tributaries, directs surface water from the Interior Plains in eastern Kansas into the Ozark area to discharge into the Missouri River along the northern border of the study area. This is the only large surface-water system that drains into the Ozark area; all other surface waters drain away from or around the uplifted Ozark region. The Blackwater River and other smaller streams drain water in the northwestern corner of the study area to the Missouri River. The Spring, White, Buffalo, and Illinois Rivers and other smaller streams drain the southern and southwestern third of the study area and discharge into either the Neosho or Arkansas Rivers. The eastern one-third to one-half of the study area is drained by the Gasconade, Meramec, Big, St. Francis, Black, Current, and Eleven Point Rivers and other smaller streams that discharge directly into either the Missouri or Mississippi River or discharge into rivers in the Mississippi Alluvial Plain.

\section{TECTONIC ACTIVITY AND DEPOSITIONAL HISTORY}

Crystalline rocks of Precambrian age form the foundation upon which younger sedimentary rocks were deposited during periods of submergence of the Ozark area. Magmatic activity in late Precambrian time resulted in several periods of granitic intrusion into middle Precambrian metasedimentary rocks. Late Precambrian volcanic activity created a wide belt of elevated volcanic rock, part of which supports the present-day Ozark Plateaus (Snyder, 1968). The predominantly rhyolitic and granitic basement rocks of the Ozark uplift are part of an epizonal graniterhyolite complex that extends in a large band from western Texas to western Ohio; (Lidiak and others, 1966; Muehlberger and others, 1966, 1967). This complex probably formed the continental divide in Late Precambrian time. There is evidence, in the form of 1,400-million-year-old stromatolitic limestones, of at least one Precambrian marine inundation, but no extensive sedimentary record remains (Stinchcomb, 1976). Metamorphic rocks constitute a small part of the basement rocks in the Ozark Plateaus and primarily are the result of contact metamorphism between magma intrusions and the host rocks.

Precambrian rocks crop out in two areas of the Ozark Plateaus: a larger area located in and slightly southwest of the St. Francois Mountains (fig. 5) and a much smaller area consisting of five small hills in Mayes County, Oklahoma (fig. 3). The St. Francois Mountains are the surface expression of a broader region of volcanic and granitic rocks termed the St. Francois terrane (Kisvarsanyi, 1979, 1981). The 1,500-million-year-old rhyolitic ash-flow tuffs exposed in this area are the oldest rocks in the province. Rhyolite also is dominant in a second volcanic province at the southwestern edge of the Ozarks in northeastern Oklahoma, but the rocks there are approximately 200 million years younger than those within the St. Francois terrane (Denison, 1981). After the two periods of major extrusive volcanic activity, and before the region was inundated by the transgressing Cambrian sea, the Precambrian surface was subjected to millions of years of erosion and provided enormous quantities of sediments to basins located southeast and northwest of the Ozarks. Structural and geochemical investigations of the St. Francois terrane indicate that it was once a major volcanic feature and that thousands of feet of volcanic rock were eroded from the Precambrian surface. Southwest of the St. Francois terrane, in the central part of the Ozark Plateaus, volcanic rocks were completely removed by erosion, exposing the underlying granitic rocks. The resulting rugged topography of the buried Precambrian surface along the ancient continental divide is evident wherever the density of drillholes that penetrate the Precambrian is sufficient to detect abrupt variations in altitude within short distances. Away from the narrow divide the Precambrian surface is more rolling; occasional hills rise a few hundred feet above the plain (Snyder, 1968).

Tectonic activity and erosion of large quantities of overburden during periods when the Ozark land mass was lifted above sea level created faults and fractures in the Precambrian basement. A major rift (New Madrid rift zone) along the southeastern edge of the Ozark Plateau beneath what is now the Mississippi Alluvial Plain also contributed to regional faulting and fracturing. The numerous faults and fractures exhibit preferential orientation to the northwest-southeast and northeast-southwest, and 


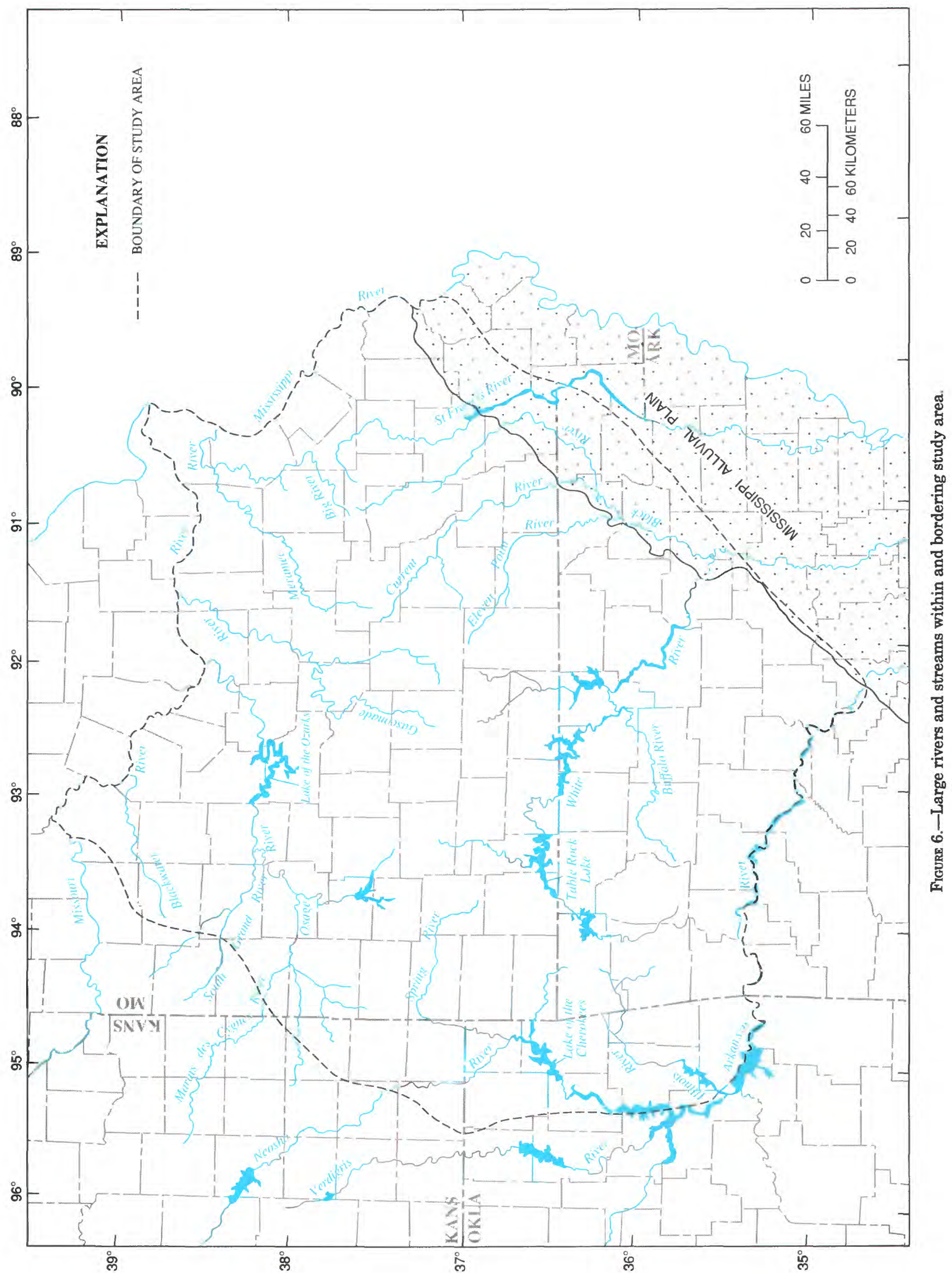


they provide avenues for movement of ground water through otherwise virtually impermeable rock. Many of the faults and fracture zones in younger consolidated Paleozoic rocks in the eastern part of the Ozarks are the result of repeated differential movement across weak zones associated with faults in the underlying basement rocks.

Where they are exposed today, Precambrian rocks usually are weathered to a distinctive dark red soil. Another characteristic weathering product is the "black sand" found in small creeks and streams throughout the St. Francois Mountains. Subsurface evidence of the erosional history is provided by the presence of an arkose conglomerate at the base of Cambrian rocks.

Overlying the Precambrian basement complex beneath the study area is a sequence of Paleozoic sedimentary rocks, ranging in thickness from near 0 to more than 6,000 feet (fig. 7). Generally, these rocks are thin to absent in the vicinity of the St. Francois Mountains and northeastern Oklahoma; they are much thicker where the flanks of the Ozark uplift dip into adjacent basins. A stratigraphic column identifying the sequence of geologic formations that constitute the Paleozoic rocks in parts of the four-State area is shown in table 1. General descriptions of the stratigraphic relations among these formations and the areal distribution, thickness, lithology, and paleontology of the formations are available in Caplan (1954 and 1957), Huffman (1958), Koenig (1961), and Zeller (1968).

Stratigraphic nomenclature varies to some degree primarily because geologic nomenclature has developed somewhat independently for each of the major geologic basins that surround the Ozark uplift. Many of the geologic formations, especially those composed of Silurian and younger rocks, are thick units in the adjoining basins but are thin and of limited areal extent, or missing, in the study area. Because units and their names vary within the study area, the stratigraphic nomenclature chart (table 1) has been divided into five columns, each representing a part of the study area (southeastern Missouri, southwestern Missouri, southeastern Kansas, northeastern Oklahoma, and northern Arkansas).

There are unresolved problems in the geologic history of certain formations in this region. The geologic history and formation boundaries of the deepest Cambrian rocks in the tristate area of Missouri, Kansas, and Oklahoma still are somewhat obscure, resulting in conflicting stratigraphic terminology for certain Cambrian rocks along the western and southwestern flanks of the Ozarks. For this report, the geologic history and nomenclature of the Cambrian strata in the tristate area as proposed by Kurtz and others (1975) has been used. There also is some question about the age assignment of certain Upper Devonian and Lower Mississippian formations (Koenig, 1961).

Seas advancing westward in Late Cambrian time transgressed the Ozarks as the entire study area slowly subsided. In early Late Cambrian time, a large land mass in the shallow Cambrian sea stretched north and south less than 100 miles west of the Kansas-Missouri and Oklahoma-Arkansas state lines. Large islands were present in the St. Francois Mountains region of southeastern Missouri and in northeastern Oklahoma and northwestern Arkansas. The Lamotte Sandstone, formed from the first Cambrian sediments to be deposited upon the Precambrian surface, originated as permeable wellsorted sands that probably were derived from the Precambrian land mass in southeastern Missouri. The clean quartzose sandstone, deposited in a shallow-water shelf environment, contains a basal arkosic conglomerate composed of weathered and broken Precambrian rock.

Deposition of sand that forms the Lamotte Sandstone was followed by deposition of sediments that now constitute the Bonneterre Dolomite, Davis Formation, and Derby and Doe Run Dolomites. The Bonneterre Dolomite, initially deposited as a calcareous mud, contains large reef and back-reef facies that encircle at least three sides of the St. Francois Mountains (Gerdemann and Myers, 1972). The sediments were later lithified as the sea regressed, and the near-reef facies underwent subsequent dolomitization in the mixing zone where depositional seawater was flushed from the limestone by freshwater of meteoric origin. The offshore facies have retained their limestone composition. The reefs are evidence that the Precambrian volcanic rocks of the St. Francois Mountains were islands in the Late Cambrian sea. The permeable reef facies are the site of one of the world's largest lead-zinc-copper districts. The metals are reported to have been transported to the area by hot sodium-calcium-chloride brines and precipitated as sulfides by biogenically reduced sulfur (Gerdemann and Myers, 1972).

Less permeable clay, silt, and sand were more prevalent during the later stages of deposition of sediments that formed the Bonneterre Dolomite and the overlying Davis Formation. The shale content of the Davis Formation is considerably larger than that of the other Cambrian formations and probably indicates cyclic deposition of calcareous mud and clay during a period in which the Cambrian sea was shallow over much of the Ozarks. A major facies transition zone that trends approximately north and south 


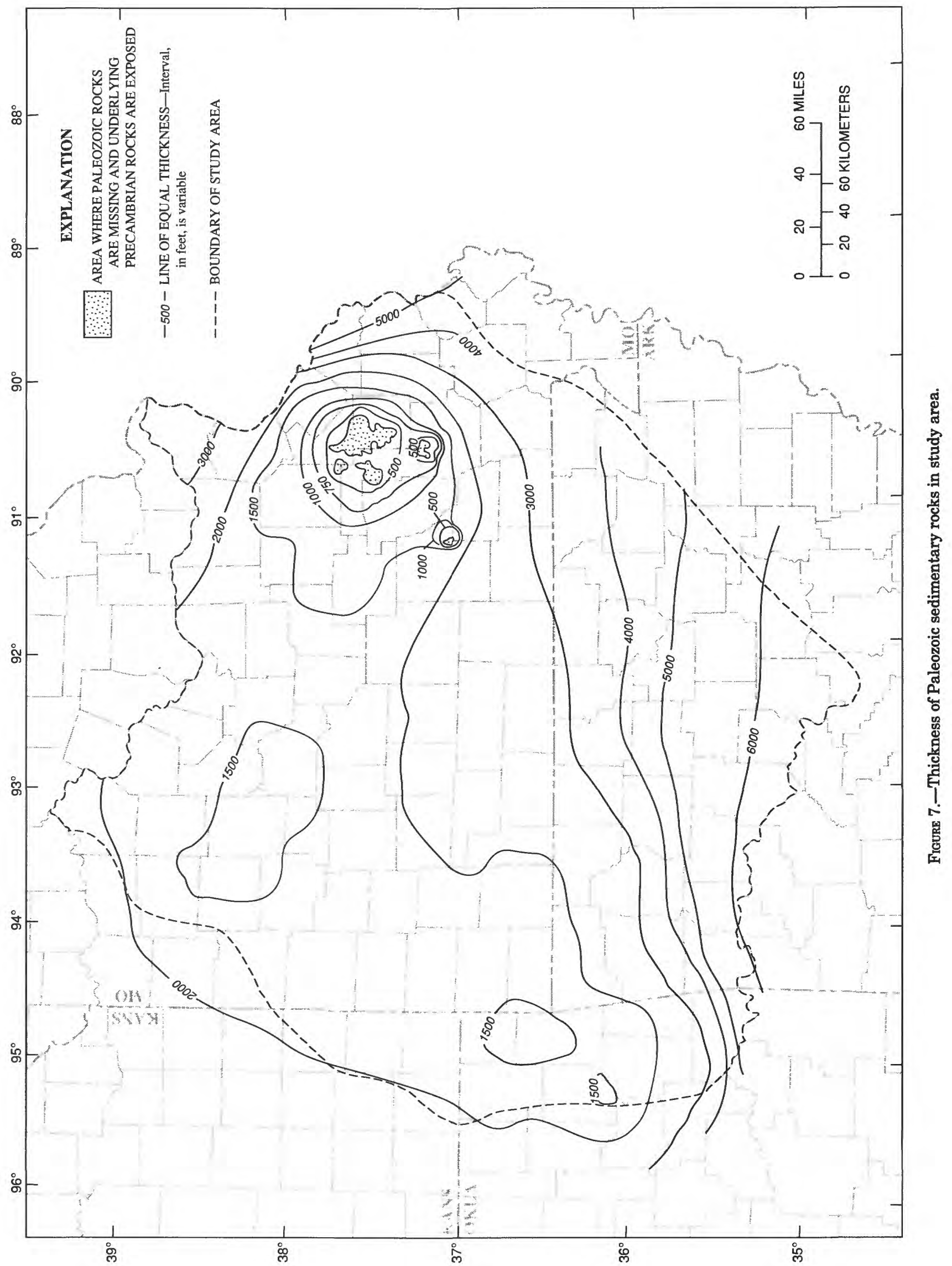


through western Missouri and Arkansas separates the Lamotte Sandstone, Bonneterre Dolomite, and Davis Formation in the east from a related, timetransgressive, near-shore facies, the Reagan Sandstone (Kurtz and others, 1975), in the west.

As the sea again transgressed upon the Ozark area, calcareous mud with some clay and silt, now represented by the Derby and Doe Run Dolomites, was deposited offshore. The Derby and Doe Run Dolomites are regarded as transition units between underlying rocks that contain a large fraction of clastic material and overlying rocks that contain only small quantities of clastic material. Continued inundation of the area was accompanied by thick deposits of calcareous mud. At the close of Late Cambrian time, the entire area was uplifted and the lithified calcareous mud was diagenetically altered to dolostone as an expanding zone of freshwater moved through the rocks. The deposits are now represented by the Potosi and Eminence Dolomites, the uppermost Cambrian formations in the study area. Both the Potosi and the Eminence Dolomites can be characterized as massively bedded, medium-grained dolostones.

The Ozark uplift and other major arches and basins of the midcontinent began to develop near the end of Late Cambrian time and throughout Early Ordovician time (fig. 8). At first, the structural features resulted more from subsidence of surrounding basins than from uplift of the Ozark domal mass. The Ozark dome generally remained below water, but sedimentation atop the dome was thinner than in the basins. An unconformity between Cambrian and Ordovician rocks marks emergence of the Ozark landmass. Renewed submergence of the area in Early Ordovician time initiated an interval in which thick deposits of mainly calcareous sediments were deposited. These sediments were subsequently lithified and extensively dolomitized and are now represented by the Van Buren Formation, Gasconade Dolomite, Roubidoux Formation, Jefferson City Dolomite, Cotter Dolomite, Powell Dolomite, and Smithville Formation. The only notable exceptions to the dominance of dolostone in these formations are the Gunter Sandstone member of the Van Buren Formation (used as a marker in both field surveys and subsurface mapping) and variable quantities of sandstone in the Roubidoux Formation (ranging from as little as 10 percent to nearly 100 percent). A major unconformity marks the end of this depositional period and signals a change in the tectonic activity of the Ozark Plateaus. Uplift of the Ozark area resulted in considerable fracturing and faulting of the competent carbonate rocks. Dolomitization occurred as freshwater flushed formational seawater from the rocks. Erosion of the dome was deep and widespread and resulted in the development of an extensive paleokarst. The unconformity marks the beginning of a series of major and minor regressions and transgressions of the sea across the Ozarks.

Sedimentation in the advancing seas at the beginning of Middle Ordovician time began with permeable sands that are represented by the Burgen Sandstone at the extreme southwestern edge of the Ozark Plateaus (Huffman, 1958). It continued with the more widespread sand deposits that formed the St. Peter Sandstone. A sequence of mainly limestone and dolostone formations, beginning with the Dutchtown Formation (Koenig, 1961) and Joachim Dolomite and ending with the Kimmswick Limestone (equivalent to the Viola Limestone of Oklahoma), constitutes the remaining sedimentary rocks attributed to this period of inundation. Sediments of the carbonate sequence were not limited to calcareous mud; sand, clay, and silt also were deposited in significant quantities. The formations deposited during this transgression are generally thinner and have smaller areal distribution than those deposited during the Early Ordovician transgression.

Deposits of Late Ordovician age are not well represented in the Ozark Plateaus. Relatively thin deposits of calcareous mud, clay, sand, and silt are characteristic of the shallow-marine environment of Late Ordovician time. Rock sequences that currently (1987) represent the lithified and diagenetically altered sediments generally are thin or absent throughout most of the Ozarks. The Fernvale Limestone, Sylvan Shale, and Cason Shale are confined to the Arkansas Valley and the southwestern and southern flanks of the Ozark Plateaus. Likewise, the Cape Limestone (Koenig, 1961), Maquoketa Shale, Thebes Sandstone, Orchard Creek Shale, and Girardeau Limestone are confined to a small area along the eastern boundary of the Ozark Plateaus. Each of the formations stratigraphically bounded by the top of the Kimmswick (Viola) Limestone and the base of the Thebes Sandstone are unconformable with overlying and underlying rocks, indicating that the sediments from which these rocks formed were deposited during a series of relatively rapid regressions and transgressions of the Late Ordovician sea. It is possible that much of the Ozark highlands remained exposed throughout the Late Ordovician and that most or all of these sediments were not deposited in the interior of the Ozarks. The permeability of the exposed carbonate rocks increased throughout the Late Ordovician.

Silurian and Devonian sediments also are represented only along the flanks of the Ozark uplift. These two geologic periods are characterized by short 


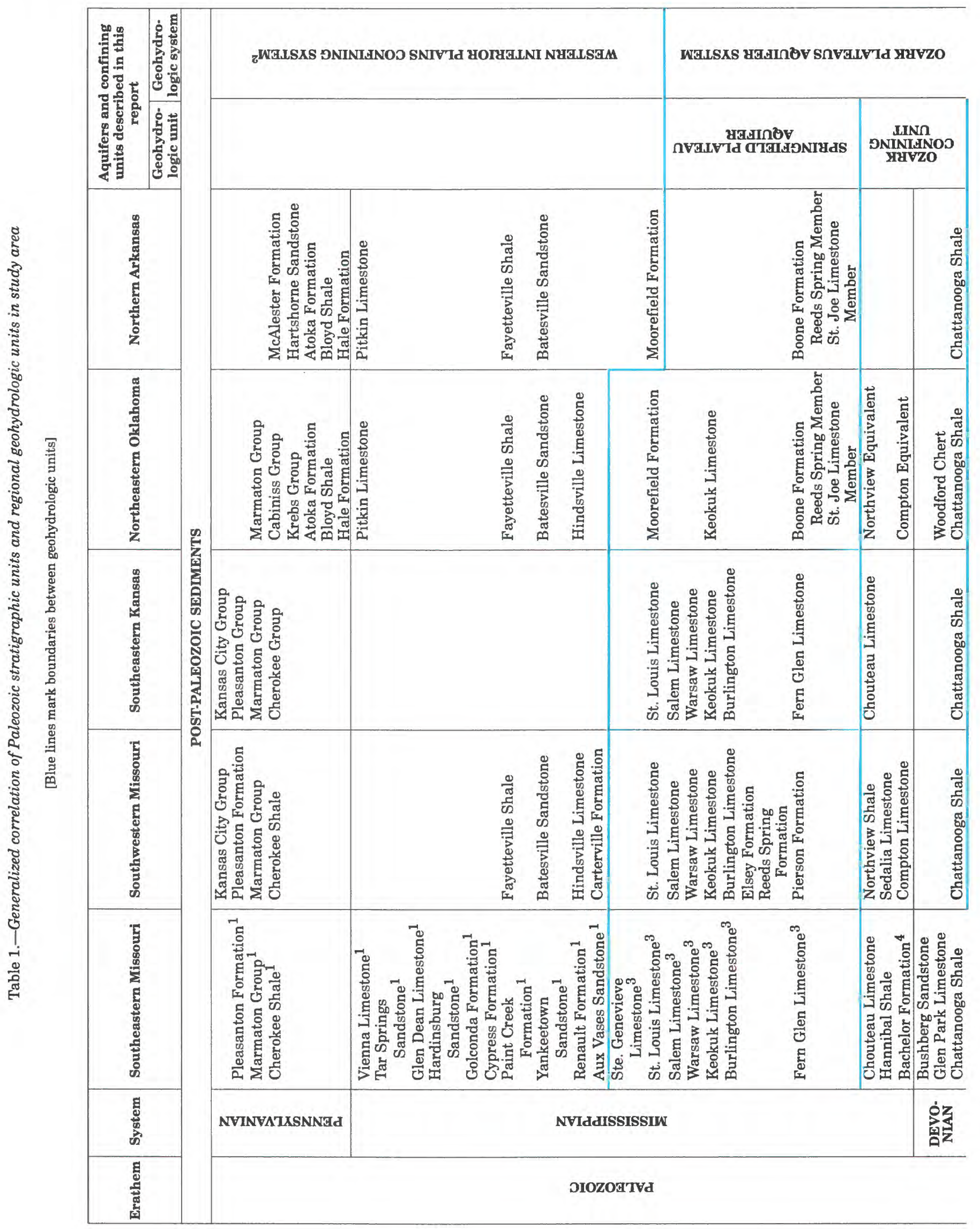




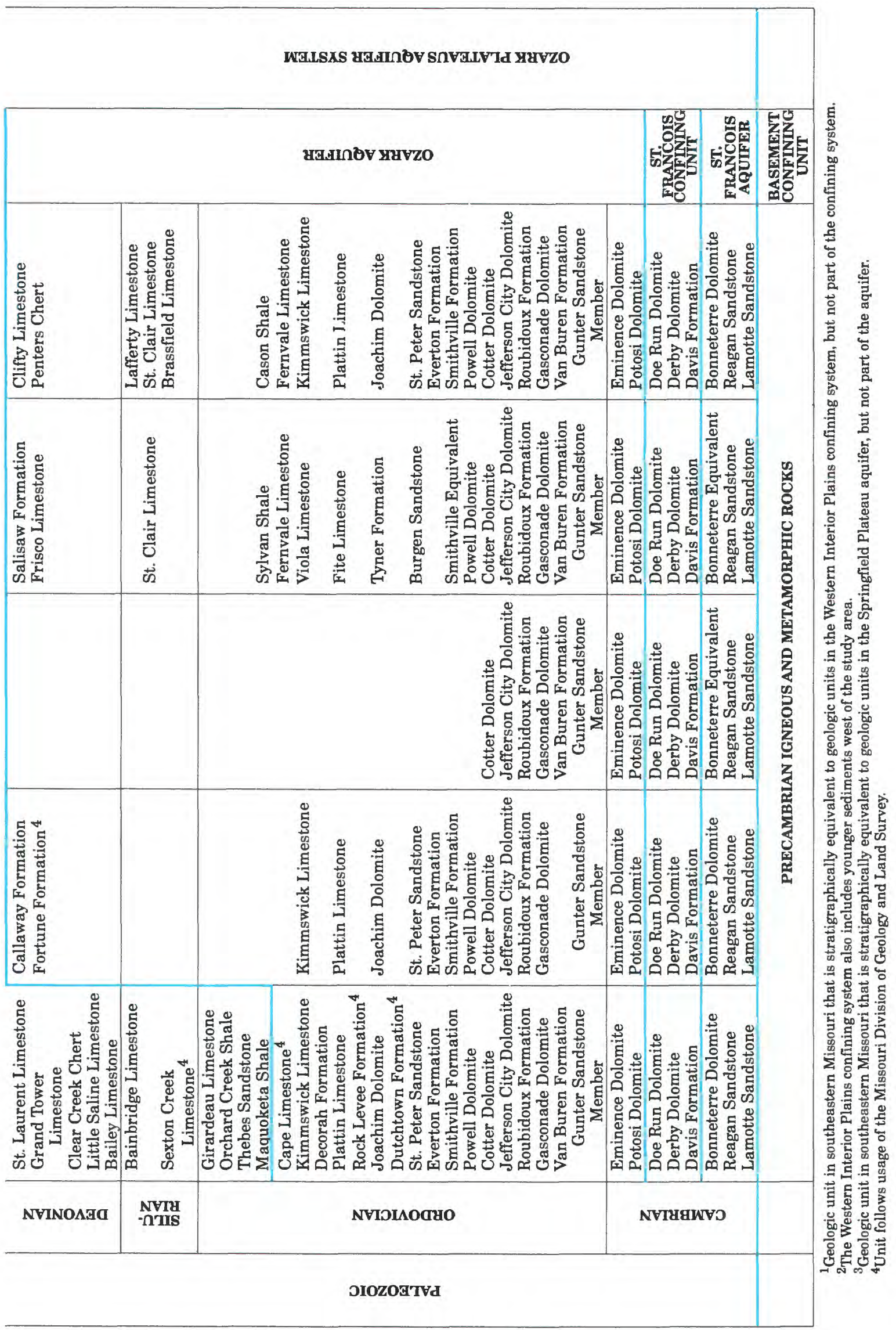


episodes of submergence and emergence of the Ozarks as represented by unconformable geologic contacts. Sediments during Silurian time were mainly calcareous mud. By the latter part of Devonian time, less permeable clay and silt had become the dominant sediments. Rocks assigned to these periods of deposition generally are thin, but thick (up to $1,000 \mathrm{ft}$ ) deposits, primarily composed of limestone and dolostone, cover the extreme eastern flank of the Ozarks, and a smaller thickness of Silurian and Devonian rocks remain beneath the Arkansas Valley. The Chattanooga Shale (Late Devonian) represents one of the more extensive and hydrologically important geologic formations lithified from the clay parent material. Major erosional events of the Ozarks in Missouri mark the close of both Silurian and Devonian time. Regional freshwater aquifers were developed, and the permeability of underlying Ordovician and Cambrian rocks was greatly enhanced.
The Ozark Plateaus have undergone two major cycles of submergence and uplift since Devonian time. At the end of Devonian time and the beginning of the first depositional cycle, Mississippian sediments, mainly calcareous mud and less permeable clay, were deposited in the advancing sea. These deposits have lithified to form the thin, relatively impermeable limestone and shaly limestone formations (Compton Limestone, Sedalia Limestone, Hannibal Shale, and Northview Shale) that are present in the Springfield Plateau and along the northern and western flanks of the Ozarks. These sediments were covered by much thicker deposits of calcareous mud that now are represented by massive, permeable limestone formations, such as the Boone Formation and equivalents and the Burlington and Keokuk Limestones. The limestone formations also contain large quantities of chert. Chert is less common in the thinner and less permeable overlying rocks of the Warsaw Lime-

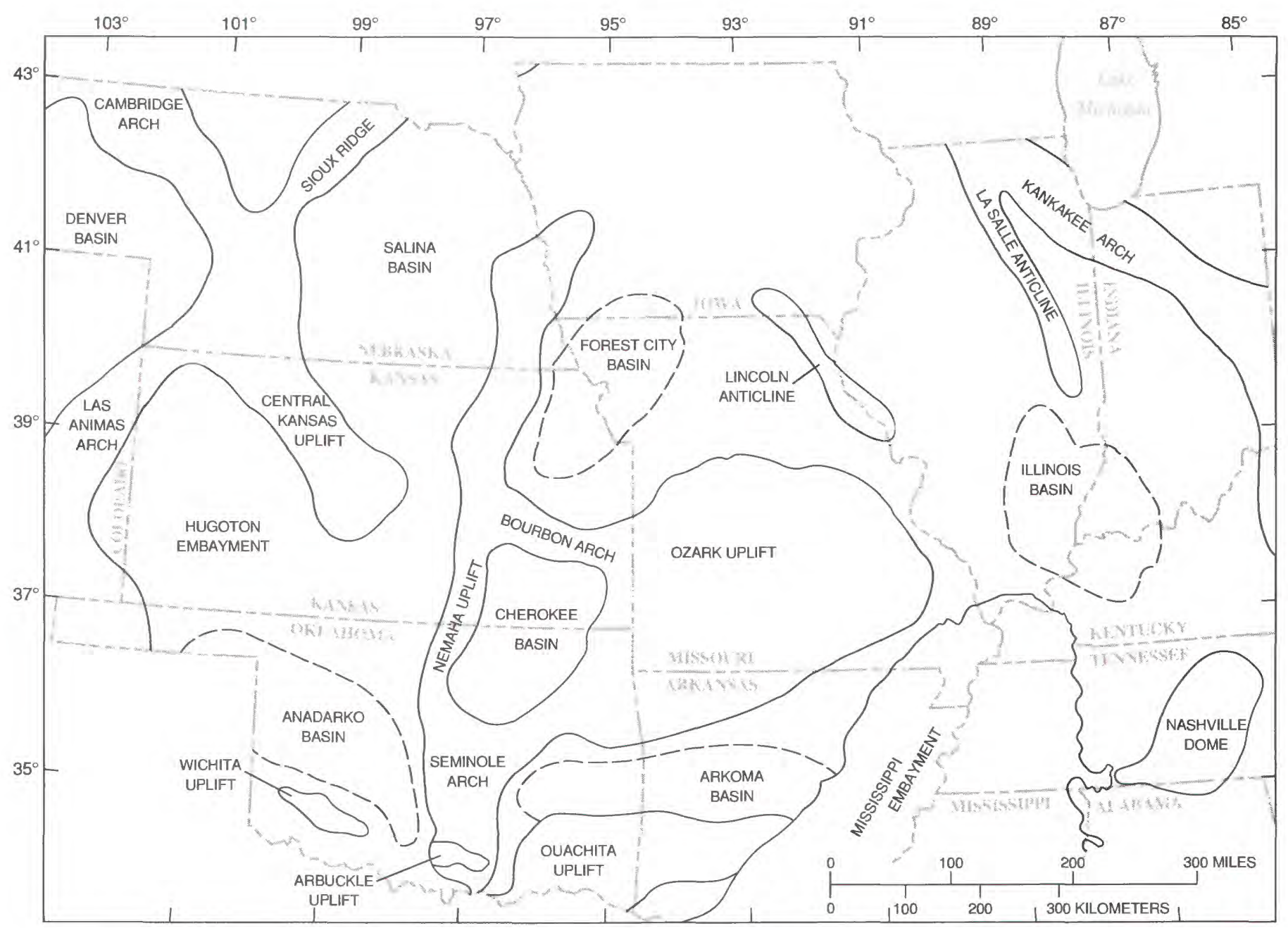

Figure 8.-Structural features of the midcontinent (modified from Jorgensen and others, 1993). Dashed lines indicate approximate location. 
stone, Salem Limestone, St. Louis Limestone (Moorefield Formation), and Ste. Genevieve Limestone. The top of the Ste. Genevieve Limestone is marked by a significant erosional surface formed during a period of emergence of the Ozark landmass from the Mississippian sea.

Several hundred feet of Upper Mississippian rocka stratigraphic sequence from the Aux Vases Sandstone to the Vienna Limestone-is limited to the extreme eastern flank of the Ozarks and may never have covered the remainder of the Ozark Plateaus. Sand that lithified to form the Aux Vases Sandstone probably was derived from the exposed Ozark highland. The Aux Vases Sandstone locally is cemented with silica, which reduces the permeability of these rocks. Other geologic formations in this sequence generally contain significant quantities of shale interbedded with lesser quantities of limestone and sandstone. The composition of these low-permeability rocks indicates that the parent material was deposited in a low-energy environment. These formations have not yet been correlated with Upper Mississippian rocks of the southwestern and southern parts of the study area as represented by the Carterville Formation, Hindsville Limestone, Batesville Sandstone, and Fayetteville Shale. Erosion at the end of the Mississippian Period removed Mississippian strata from the St. Francois Mountain region and perhaps much of the present Salem Plateau.

The second cycle of deposition began in Early Pennsylvanian time when the sea again transgressed over most, if not all, of the Ozark uplift. Large quantities of clay, sand, and calcareous mud were deposited atop Mississippian rocks around the circumference of the Ozarks and directly on Ordovician rocks in the center of the Salem Plateau. Renewed uplift of the Ozarks in Middle Pennsylvanian time ended the sedimentation. The lithified sediments formed thick layers of Pennsylvanian shale, sandstone, and limestone across much of the Ozarks. Widespread and deep erosion occurred after Pennsylvanian seas receded and continues to present time; it has removed all but a few remnants of the Pennsylvanian deposits from the Ozark Plateaus.

Remnants of Pennsylvanian rock can be found in a few scattered areas about 100 miles northwest of the St. Francois Mountains. These rocks are in direct contact with the Jefferson City Dolomite of Ordovician age, this juxtaposition providing evidence of the effectiveness of the post-Mississippian erosion. The thickness of Pennsylvanian rocks increases west and south of the Ozark Plateaus. Removal of this thick layer of rock from the Ozark uplift released stress previously developed in the underlying Mississippian and Ordovician rocks, resulting in faults and large fractures that approximately parallel the major and minor axes of the uplift (fig. 9). One set of faults and fractures is aligned approximately 55 degrees west of north, and the other approximately 35 degrees east of north. Lineament studies of Landsat imagery show evidence for many more deep-seated faults and fractures (Kisvarsanyi and Martin, 1977). The deep lineaments indicate tectonic activities that resulted in extensive breaks in the crustal rocks and associated block movements. These deep-seated faults and fractures are seen in the surface or shallow subsurface as slip-strike features as well as faults with vertical movement.

The southeastern flank of the Ozark uplift was submerged in early Mesozoic time as a result of renewed tectonic activity along the New Madrid rift zone (Schwalb, 1982). Submergence was followed by deposition of hundreds of feet of sand and clay of Cretaceous, Tertiary, and Quaternary age in the Mississippi Embayment (fig. 8). These post-Paleozoic deposits are in direct contact with Early Ordovician carbonate rocks, the latter being a buried southeast extension of the present-day Salem Plateau (fig. 5). The boundary between the Ozark Plateaus and the more recent sediments of the Mississippi Alluvial Plain, termed the "Fall Line," is a well-defined, almost linear transition from the rugged topography of the Ozarks to the nearly flat alluvial plain. Currently, the Ozark uplift is tectonically stable.

\section{GROUND-WATER FLOW AND GEOHYDROLOGIC PROPERTIES OF THE OZARK AREA}

The boundaries of the Ozark Plateaus aquifer system are determined by a combination of geologic and hydrologic conditions near the flanks of the Ozark Plateaus province. The northern boundary of the aquifer system generally is defined by the Missouri River valley, a major discharge area (fig. 10). Similarly, the Mississippi River valley is a discharge area from its confluence with the Missouri River valley to the Mississippi Alluvial Plain, and this stretch is considered the northeastern boundary of the aquifer system. There is some ambiguity about this boundary: The lowermost geohydrologic units dip so steeply and are so deeply buried along the eastern margin of the Ozarks that few data are available to verify that the Mississippi River valley is a discharge area for these deeply buried units. However, data on ground-water chemistry of the deep aquifers at the north and south ends of this reach of the Mississippi River indicate highly mineralized water is present along the eastern 


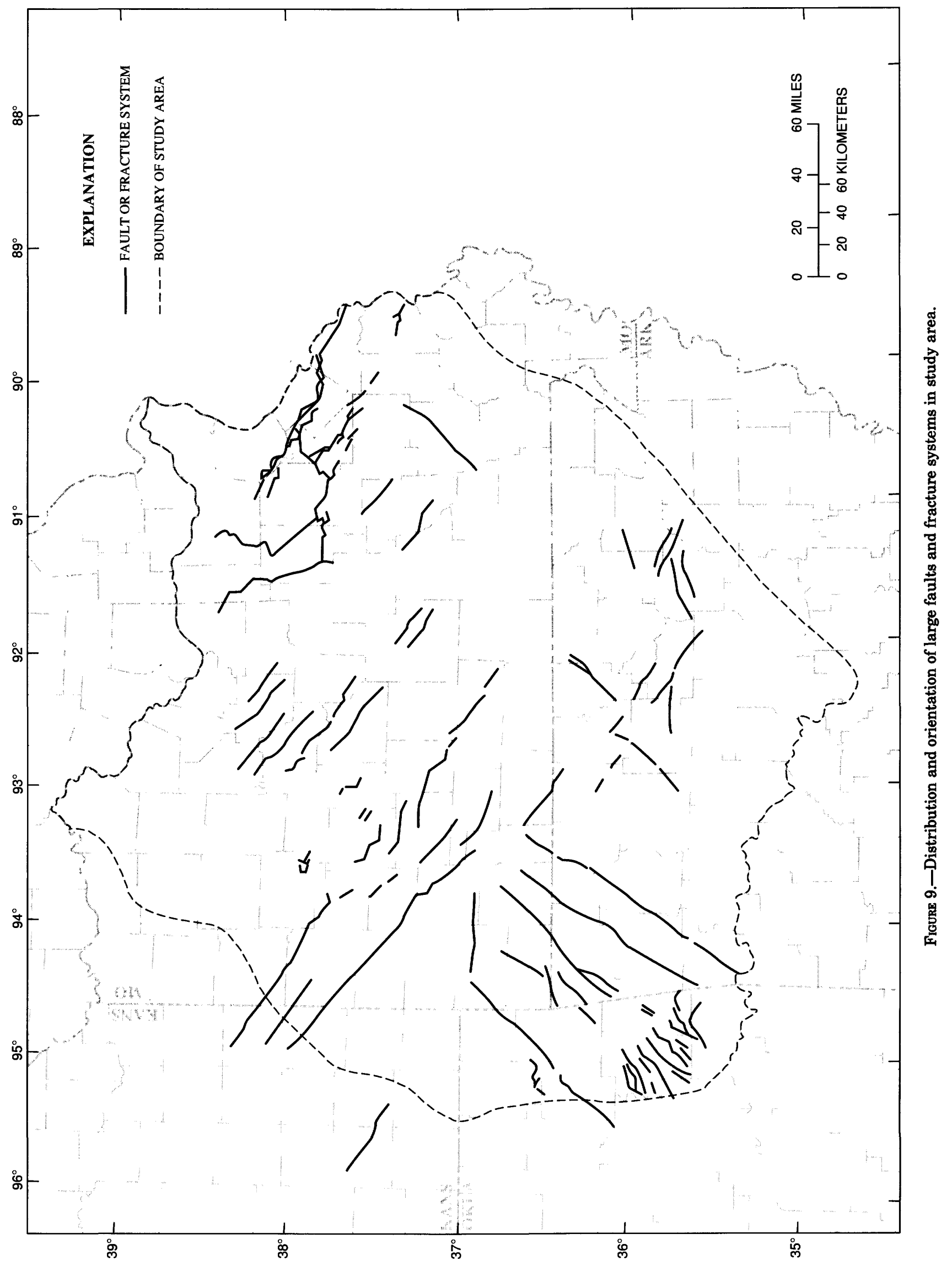




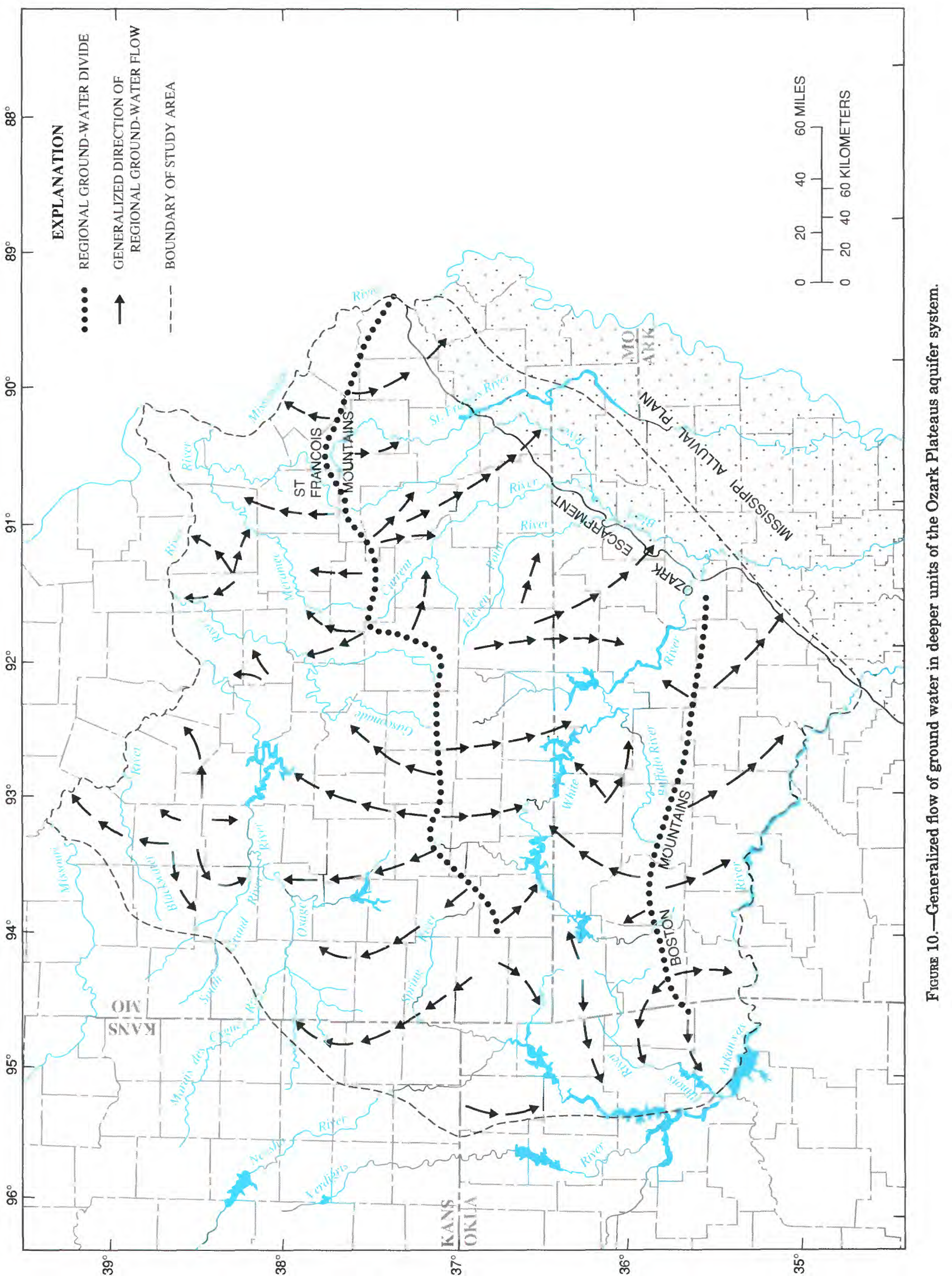


flanks of the Ozarks. This finding suggests that freshwater from the Ozarks probably discharges upward into shallower geohydrologic units and does not flow eastward beneath the Mississippi River.

The Mississippi Alluvial Plain approximately marks the southeastern boundary of the Ozark Plateaus aquifer system. Most of the ground water that flows through Paleozoic rocks toward the Mississippi Alluvial Plain discharges upward into overlying Cretaceous, Tertiary, and Quaternary sediments near the Ozark Escarpment, or "Fall Line," the line of bluffs that marks the surface contact between Paleozoic rocks and alluvium (figs. 5, 10). A small part of the southeastward-flowing freshwater flows a greater distance beneath the post-Paleozoic sands and clays of the alluvial plain. The maximum distance that freshwater moves to the southeast beneath the alluvium is not known.

The southern boundary of the aquifer system is thought to be approximately parallel to the Arkansas River valley. Ground water in the Ozark Plateaus aquifer system is saline only in the region between the Boston Mountains and the Arkansas River.

A complex mixing zone is present along the west edge of the aquifer system where freshwater moving westward from its source in the Ozark highlands meets salinewater moving eastward through the Western Interior Plains aquifer system (Jorgensen and others, 1993). The western boundary of the Ozark Plateaus aquifer system is located in a broad, topographically low area. Ground-water quality along the boundary is characterized by the transition between nearly stagnant salinewater in the Western Interior Plains aquifer system and freshwater in the Ozark Plateaus aquifer system. At this broad, topographically low area the freshwater either discharges into shallower aquifers or mixes with the salinewater and discharges as base flow into the Osage and Neosho Rivers and their tributaries or into the Missouri and Blackwater Rivers and their tributaries.

Recharge to the Ozark Plateaus aquifer system is almost entirely from direct infiltration of precipitation. Precipitation that is not returned to the atmosphere as evapotranspiration or routed to streams by overland flow may infiltrate the unsaturated zone rather quickly, because soil and subsoil in the Ozarks is thin, near-surface faults and fracture systems are common, and dissolution of the predominating carbonate rocks is widespread.

An important control on ground-water flow in the Ozark Plateaus aquifer system is a regional groundwater divide that parallels a major topographic ridge extending across the Ozarks from the tristate area of Kansas-Oklahoma-Missouri to the Mississip- pi River east of the St. Francois Mountains (fig. 10). The divide separates the physiographic province into two approximately equal-area ground-water provinces. North of the divide, ground water moves from the uplands and discharges into the Missouri, Mississippi, Meramec, Osage, and Gasconade Rivers and their tributaries. South of the divide, ground water discharges into the Neosho and Spring Rivers to the southwest and the White River to the south. Generally, water flowing in the deeper part of the aquifer system discharges only to the largest rivers, whereas water moving through the upper part of the aquifer system forms local flow patterns that terminate at the smaller streams. To the southeast, deep-flowing ground water discharges into the Mississippi Alluvial Plain, but shallower ground water is intercepted by southeast-flowing rivers such as the Eleven Point, Current, and St. Francis Rivers and their tributaries.

A second ground-water divide trends east and west across the Boston Mountains of northern Arkansas. Ground water north of the divide flows toward the White, Buffalo, and Illinois Rivers. Ground water south of the divide flows toward the Arkansas River. Because several thousand feet of Pennsylvanian shale separates the aquifer system from the Arkansas River, it is possible that much of the southward-flowing ground water does not discharge to the Arkansas River, but instead turns southeast to discharge upward into more permeable postPaleozoic sediments of the Mississippi Alluvial Plain. Streamflow measurements on northern tributaries of the Arkansas River under low-flow conditions do not indicate a source of water from the deeper geohydrologic units. Saline springs rising from Paleozoic rocks beneath the Mississippi Alluvial Plain may be evidence of the discharge of water into the alluvium after the water has traveled beneath the Pennsylvanian shale (Augustine Ludwig, U.S. Geological Survey, oral commun., 1985). There are no hydraulic-head data from the deeper aquifers to support the discussed flow pattern south of the Boston Mountains.

The flow pattern in the Ozark Plateaus aquifer system is mainly topographically controlled, but local perturbations are produced by major faults and their associated fracture systems. The large fracture systems in the Ozark Plateaus are oriented in two nearly orthogonal patterns (fig. 9). Many regions having extensive fractures and faults are characterized by increased or decreased permeability in the plane of the fractures. The effect of fractures on the movement of ground water in the Ozarks region is most apparent on a local scale. Regionally, it is more diffi- 
cult to detect the effects of particular fractures on ground-water flow, especially where the flow is strongly influenced by topography.

\section{REGIONAL GEOHYDROLOGIC UNITS}

The geohydrologic units of the Ozark area are classified on the basis of two characteristics: (1) the general hydraulic properties of the rock unit and (2) the hydrologic relation of that unit to adjacent units. The geohydrologic unit boundaries are not constrained by geologic age boundaries or stratigraphic unit boundaries (Jorgensen and Rosenshein, 1987). Because regional facies changes can spatially alter the hydraulic characteristics of a rock unit, the same geologic formation can be assigned to different geohydrologic units in different parts of the study area. Where possible, regional aquifer units of the Ozark Plateaus aquifer system are named after the physiographic region in which they generally are the main source of ground water, and regional confining units are named after the aquifers they confine.

The relative stratigraphic position of the regional geohydrologic units in and adjacent to the Ozark Plateaus aquifer system is shown in figure 11. The basal unit, composed primarily of igneous rocks of Precambrian age, is the Basement confining unit. Overlying the Basement confining unit is the Ozark Plateaus aquifer system, a group of Paleozoic rocks subdivided into a sequence of three aquifers and two confining units. From stratigraphically lowest to highest, these geohydrologic units are the St. Francois aquifer, the St. Francois confining unit, the Ozark aquifer, the Ozark confining unit, and the Springfield Plateau aquifer. The Ozark Plateaus aquifer system is bounded on the west by the laterally adjacent and stratigraphically equivalent salinewater-bearing rocks of the Western Interior Plains aquifer system. It is overlain along the western and southern edges by the Western Interior Plains confining system. The latter two geohydrologic units are major units that stretch from the Rocky Mountains to the Ozark Plateaus. The southeastern edge of the Ozark Plateaus aquifer system subcrops beneath post-Paleozoic sediments (fig. 11) of the Mississippi Alluvial Plain. Generally, the oldest units are exposed nearest the core of the Ozark uplift at the St. Francois Mountains, producing the characteristic concentric outcrop pattern shown on geologic bedrock maps of the Ozark Plateaus province (fig. 12; Imes, 1990a). Generally, the eight geohydrologic units located within the Ozark study area (the Western Interior Plains aquifer system is not present in the study area) are continuous in the subsurface from their areas of outcrop to the boundary of the study area. Some exceptions occur locally where the rocks of the units are missing because of nondeposition or postdepositional erosion.

Three areas in the northeastern part of the Ozarks-located in and near the Missouri counties of St. Louis, Ste. Genevieve, and Gasconade (fig. 3)-are blanketed with Mississippian or Pennsylvanian consolidated deposits that are stratigraphically equivalent, but hydrologically unrelated, to the Springfield Plateau aquifer and Western Interior Plains confining system. These unnamed geohydrologic units are not important on a regional scale, but are important locally and are included in this discussion of the geohydrology of the Ozarks.

Unconsolidated deposits of Quaternary alluvial material fill the major river and stream valleys of the Ozarks, especially along the Missouri and Mississippi River valleys. Thick deposits of unconsolidated Cretaceous, Tertiary, and Quaternary sediments onlap part of the Ozark Plateaus aquifer system in southeast Missouri and northeast Arkansas (fig. 12). These unconsolidated sediments, which are grouped under the general term "post-Paleozoic sediments," can yield abundant supplies of ground water. However, a detailed study of these sediments is beyond the scope of this investigation. Hydrologic and lithologic characteristics of the post-Paleozoic sediments are described in this report only to the extent that they affect ground-water flow in the underlying Ozark Plateaus aquifer system.

The geohydrologic units in the study area that underlie, compose, and overlie the Ozark Plateaus aquifer system, from the stratigraphically oldest to youngest unit, are discussed in the following sections of the report.

\section{BASEMENT CONFINING UNIT}

The Basement confining unit is considered the base of the Ozark Plateaus aquifer system in the Ozarks because no known aquifers are present beneath the unit. The confining unit is not limited to the Ozark area, but forms the base of regional ground-water flow systems throughout the Central Midwest RASA study area. The Basement confining unit is primarily composed of igneous rocks of Precambrian age, which are part of a series of extensive rhyolite-granite complexes that stretch across the midcontinent. The crystalline rocks are nearly impermeable, and wells that tap these rocks yield no significant amount of water. However, in outcrop areas where the rocks are weathered, fractured, or faulted, yield of wells may 
range from near 0 to 70 gallons per minute, but rarely exceeds 10 gallons per minute.

\section{Configuration OF THE UPPER SURFACE}

The Basement confining unit is exposed at three general locations in the Ozark Plateaus: a large area in and southwest of the St. Francois Mountains of southeastern Missouri, a much smaller area limited to five low hills in Mayes County (fig. 3) in northeastern Oklahoma, and an isolated exposure in Camden County, Missouri, named the Decatureville structure (McCracken, 1971). The St. Francois Mountains of southeast Missouri correspond to both a structural and topographic high on the surface of the Basement confining unit (fig. 13; Imes, 1989). Because many exploration wells have been drilled to locate and define commercial iron deposits in the Precambrian rocks and lead and zinc deposits in overlying sediments, the

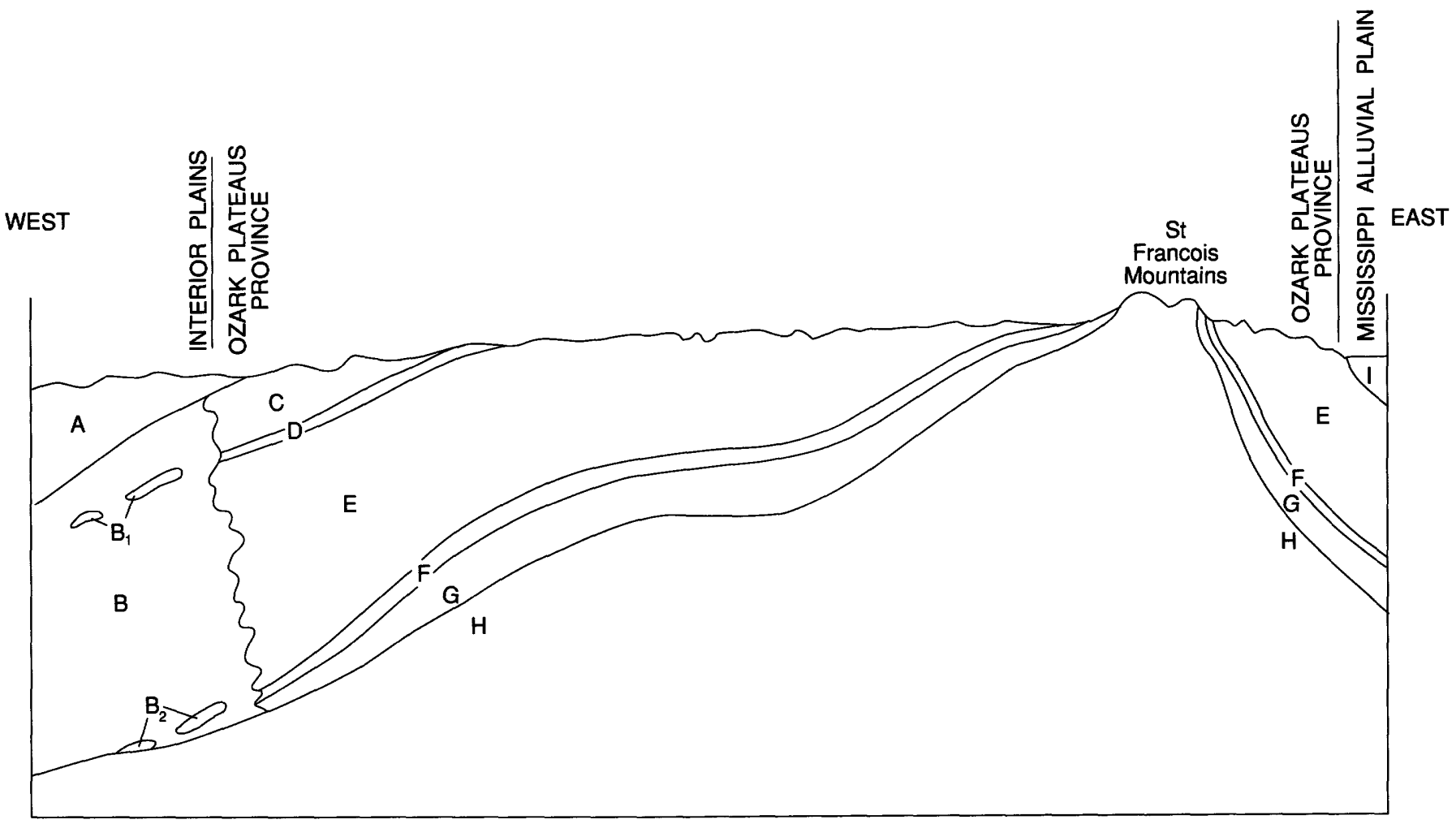

\section{EXPLANATION}

$\begin{array}{cc}\text { A } & \text { WESTERN INTERIOR PLAINS CONFINING SYSTEM } \\ \text { B } & \text { WESTERN INTERIOR PLAINS AQUIFER SYSTEM } \\ \text { B }_{1} & \text { STRATIGRAPHICALLY EQUIVALENT TO OZARK CONFINING UNIT } \\ \text { B }_{2} & \text { STRATIGRAPHICALLY EQUIVALENT TO ST. FRANCOIS CONFINING UNIT } \\ & \text { OZARK PLATEAUS AQUIFER SYSTEM } \\ \text { C } & \text { SPRINGFIELD PLATEAU AQUIFER } \\ \text { D } & \text { OZARK CONFINING UNIT } \\ \text { E } & \text { OZARK AQUIFER } \\ \text { F } & \text { ST. FRANCOIS CONFINING UNIT } \\ \text { G } & \text { ST. FRANCOIS AQUIFER } \\ \text { H } & \text { BASEMENT CONFINING UNIT } \\ \text { I } & \text { POST- PALEOZOIC SEDIMENTS }\end{array}$

Figure 11. Schematic cross section of regional geohydrologic units in and adjacent to the Ozark Plateaus aquifer system. 


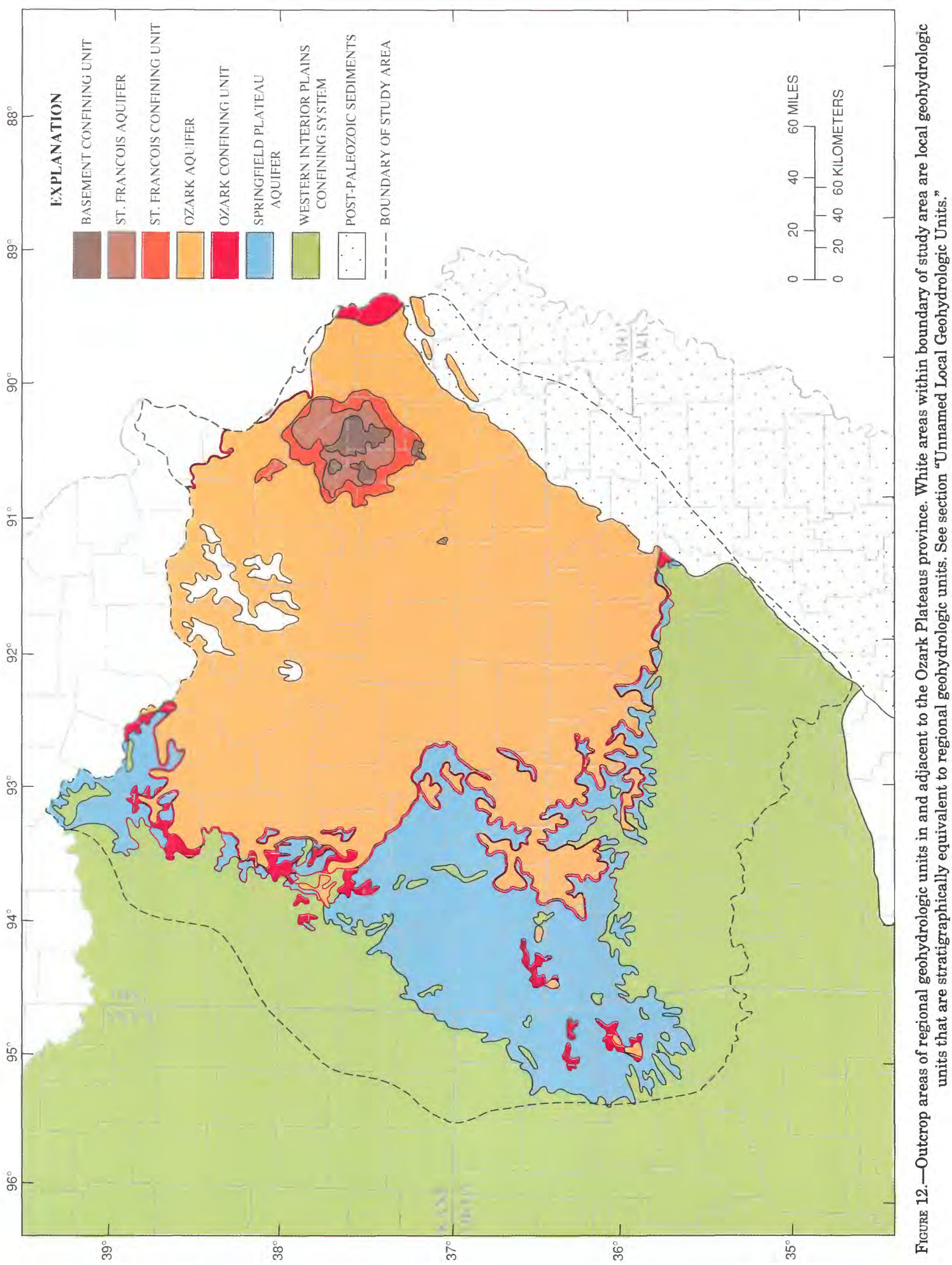




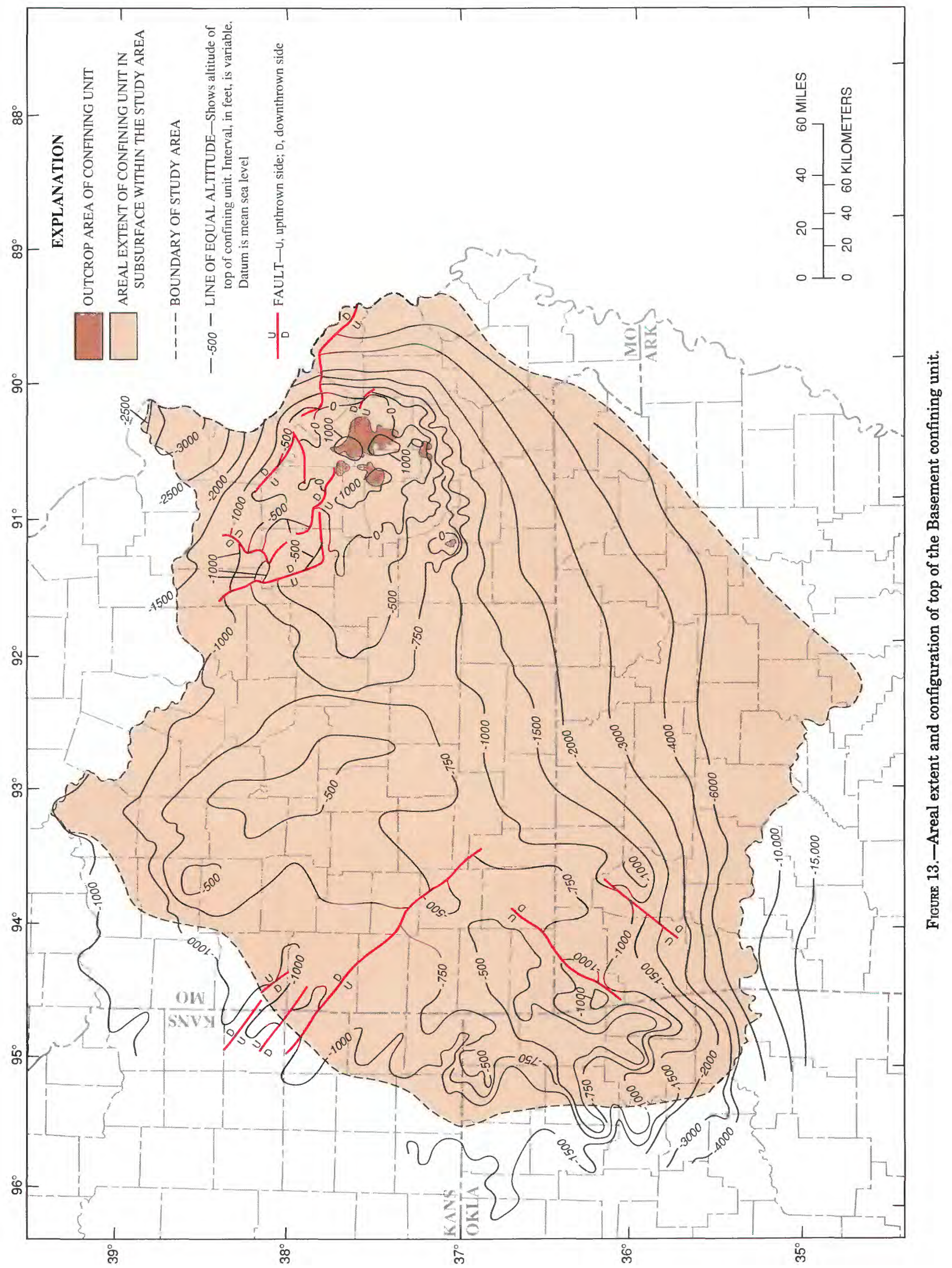


density of test-hole data in the vicinity of the St. Francois Mountains is large (Kisvarsanyi, 1975). Consequently, the surface of the Basement confining unit can be mapped fairly accurately in this area. The surface is rugged and broken by numerous faults. The altitude of the surface of the basement confining unit can vary by as much as 1,000 feet within a few miles. The generally rugged topographic features exhibited by the confining unit evolved as thousands of feet of volcanic rocks were eroded from structural highs during the several hundred million years of late Precambrian and Early Cambrian time before the submergence of the area by Late Cambrian seas.

Beyond the St. Francois Mountains, the surface of this confining unit dips steeply to the north, east, and south, where the flanks of the Ozark uplift dip into adjacent basins. To the west the surface dips more gently toward a subsurface plateau that ranges in altitude from about 400 to 1,000 feet below sea level. The subsurface plateau encompasses most of southwestern Missouri and extreme northeastern Oklahoma and northwestern Arkansas; it generally corresponds to the Ozark Plateaus physiographic province. Structure contours in figure 13 have been extended southward beyond the limit of well-log data in western Arkansas; this extension was made on the basis of seismic reflection data presented by Lillie and others (1983).

Lithology AND PERMEABILITY

Most of the exposed Basement confining unit consists of rhyolitic volcanic rocks (Kisvarsanyi, 1981). Granitic rocks were emplaced as dikes and sills beneath the rhyolitic cover in several stages. Porosity can occur in rhyolitic rocks by development of columnar jointing at the base of ash-flow tuffs and by expansion of trapped gas bubbles in lava flows (Hyndman, 1972). However, rhyolitic rocks in the vicinity of the St. Francois Mountains have little porosity and, more importantly, the pores are not interconnected. Thus, even in the more porous igneous rocks of this region, permeability is extremely small.

Secondary permeability has developed in the Precambrian basement but is mainly confined to fracture systems and faults. Fault displacements generally are on the order of tens of feet but can be as large as 1,200 feet. The faults usually are nearly vertical and are characterized by a lack of brecciation (Anderson, 1970). The extensive network of fracture and fault zones in the block-faulted Ozark uplift probably is not confined to the volcanic terrane of the St. Francois Mountains where this evidence is visible. Aero- magnetic surveys (Allingham, 1960; Denison, 1981; Kisvarsanyi, 1981) and correlation of major lineaments on Landsat imagery with physiographic features and known fault zones (Kisvarsanyi and Martin, 1977) indicate that the Precambrian surface is more fractured than suggested by well-log data.

\section{ST. FRANCOIS AQUIFER}

The St. Francois aquifer, the lowermost geohydrologic unit of the Ozark Plateaus aquifer system, is composed of permeable sandstone and dolostone overlying the Basement confining unit. Three Upper Cambrian formations are included in the aquifer: the Lamotte Sandstone, the Reagan Sandstone, and the Bonneterre Dolomite (table 1). The St. Francois aquifer is named for the geographic region, the St. Francois Mountains, where the aquifer is exposed and is used as a source of water for domestic and public supply. Wells tapping this aquifer may yield from 100 to 500 gallons per minute. However, this aquifer is rarely used beyond the outcrop area because the overlying Ozark aquifer yields more water at a shallower depth.

The geologic formations that constitute the St. Francois aquifer extend beyond the boundary of the Ozark Plateaus aquifer system. Few hydrologic data are available to verify that the boundary of the Ozark Plateaus aquifer system also represents the limit of lateral ground-water flow in the St. Francois aquifer. The boundary of the aquifer is largely delineated from potentiometric-head and dissolved-solids concentration data from the overlying Ozark and Springfield Plateau aquifers. In other words, the boundary of the St. Francois aquifer is assumed to be approximately coincident with the boundary of the overlying aquifers. There is some evidence that suggests this assumption is correct. Water levels measured during construction of a deep test well near the boundary of the Ozark Plateaus aquifer system in St. Louis County, Missouri (fig. 3), indicate that potentiometric head increases with depth. Although the St. Francois aquifer is buried to a depth exceeding 2,500 feet, the head in this aquifer is higher than heads in shallower aquifers. Thus, the Missouri and Mississippi River valleys probably are discharge areas for this aquifer. Deep wells located in Pettis and Jasper Counties, Missouri, near the western edge of the Ozark Plateaus aquifer system, yield freshwater from the St. Francois aquifer. The relatively large leakance of the overlying St. Francois confining unit, which hydraulically separates the St. Francois aquifer from the Ozark aquifer, probably ensures that the 
limit of lateral ground-water flow in the St. Francois aquifer nearly coincides with the limit of the Ozark aquifer. However, this assumption cannot be verified because of the lack of well data.

\section{Structural Features}

The St. Francois aquifer crops out in the St. Francois Mountains in broad valleys between more resistant, exposed peaks of the Basement confining unit (fig. 12). The largest unbroken outcrop area is located at the northeast edge of the St. Francois Mountains where the Basement confining unit is uplifted to within a few hundred feet of land surface. The total outcrop area is only about 590 square miles. Beyond the relatively small outcrop area, the aquifer dips into the subsurface and is buried beneath younger water-yielding rocks. The dip is steepest to the northeast and east toward the Illinois Basin and to the southeast toward the Mississippi Alluvial Plain, where the aquifer is buried to a depth of about 3,550 to 10,000 feet (fig. 14). About 60 miles west of the St. Francois Mountains, the aquifer dips less steeply into the subsurface and the unit forms a relatively flat subsurface area beneath the western half of the Salem Plateau, the Springfield Plateau, and that part of the Interior Plains within the study area. The depth of burial of the aquifer is generally between 800 and 1,500 feet in this region. The aquifer is more deeply buried in the southern part of the study area. The aquifer dips steeply into the subsurface southeast of a line extending from the extreme western tip of the Boston Mountains to the southeastern edge of the St. Francois Mountains. Burial depth exceeds 10,000 feet in the extreme southern part of the study area.

The altitude of the top of the St. Francois aquifer generally is greater than 500 feet above sea level in and near the St. Francois Mountains (fig. 15; Imes, $1990 \mathrm{~b}$ ). The altitude of the top is below sea level in the remainder of the study area except along the common border between Camden County and Laclede County, Missouri (fig. 3), where a small outcrop of igneous rocks form the core of the Decatureville structure (McCracken, 1971). The top of the aquifer generally is more than 1,000 feet below sea level along the western edge of the study area and throughout most of northern Arkansas.

THICKNESS

Thickness of the St. Francois aquifer varies considerably and seems to reflect the rugged topography of the underlying Precambrian surface (Basement confining unit). Variation of the thickness is apparent in the vicinity of the St. Francois Mountains and in northeastern Oklahoma (fig. 16; Imes, 1990b) but is not as apparent elsewhere in the study area because insufficient well-log data are available to define the thickness changes. The aquifer is missing in the center of the St. Francois Mountains of southern Missouri where the Basement confining unit crops out. The aquifer extends from the St. Francois Mountains to the boundary of the study area but locally is missing where peaks in the Basement confining unit breach the aquifer. The larger areas where the aquifer is not present in the subsurface are located in northeastern Oklahoma.

The thickness of the aquifer generally ranges from about 300 to 700 feet in southern Missouri, except near locations where the aquifer is breached. The aquifer is thickest (greater than $1,000 \mathrm{ft}$ ) beneath the Mississippi Alluvial Plain near the southeastern part of the Ozark Plateaus province. The aquifer generally ranges from about 100 to 300 feet thick in northern Arkansas. The aquifer is thinner in the western and southwestern part of the study area where the Lamotte Sandstone and Bonneterre Dolomite are not present.

\section{Lithology and Geohydrologic Properties}

The Lamotte Sandstone and the Bonneterre Dolomite form the rock matrix of the St. Francois aquifer in the eastern three-quarters of the study area. Much of the lithologic data on the Lamotte Sandstone is based on drill cuttings from wells located near the St. Francois Mountains where the formation is not so deeply buried. In this location the Lamotte generally is a well-sorted, medium-grained, quartzose sandstone containing locally derived arkosic material at or near its base. Because the sandstone is well sorted and relatively clean, the permeability of the sandstone at this location is high. The sandstone contains possible fluvial, aeolian, and beach-environment components as well as shallow-marine deposits. Less is known about this sandstone away from the vicinity of the St. Francois Mountains. In 1984, several deep test wells were drilled to the Precambrian basement in western Missouri as part of an assessment of strategic minerals in the midcontinent. Information from these strategic-mineral and other test wells in southcentral Missouri indicate that the lithology, and probably the permeability, of the Lamotte Sandstone in this area differs little from the lithology and permeability farther east. The sandstone is described by 


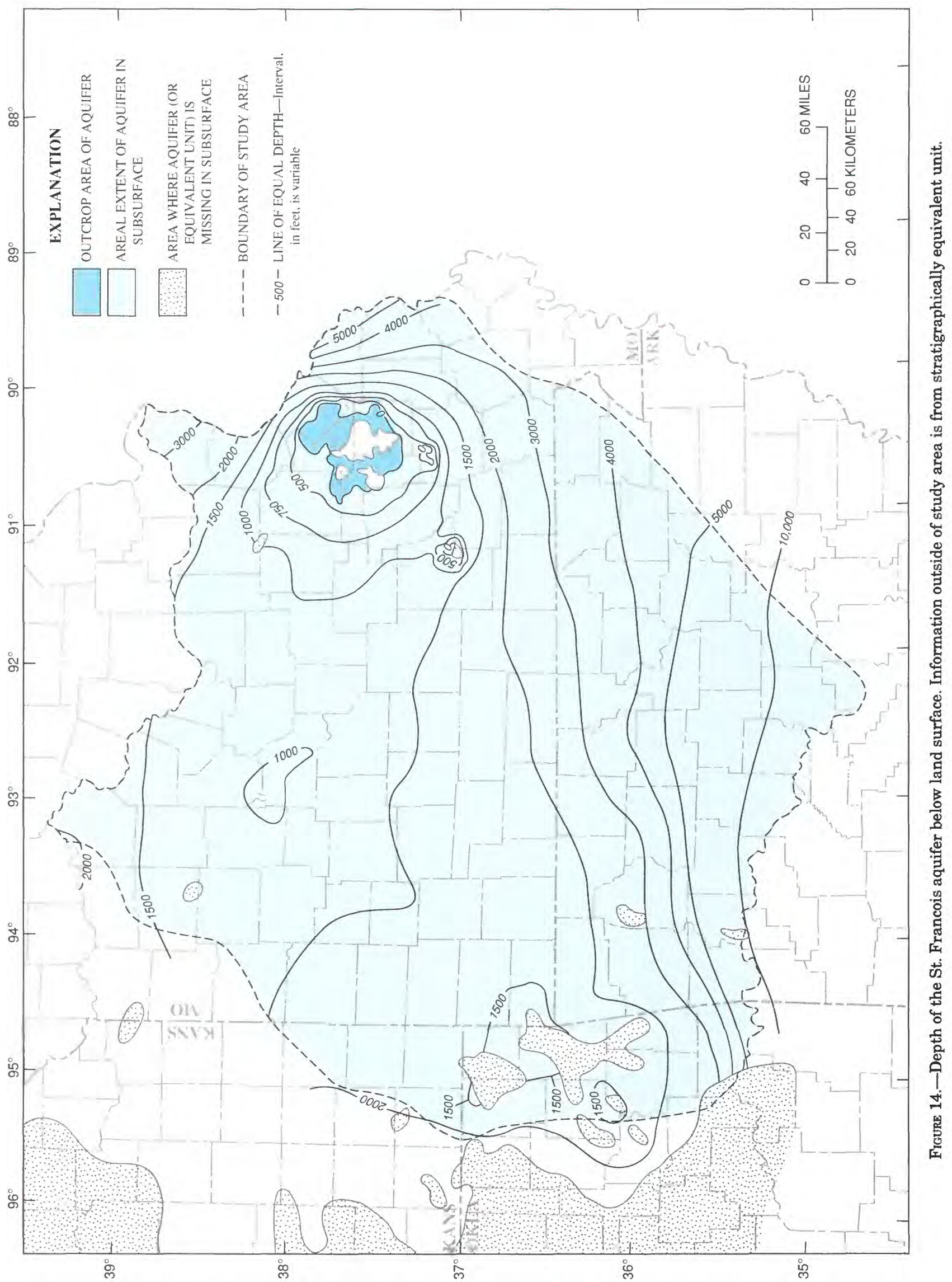




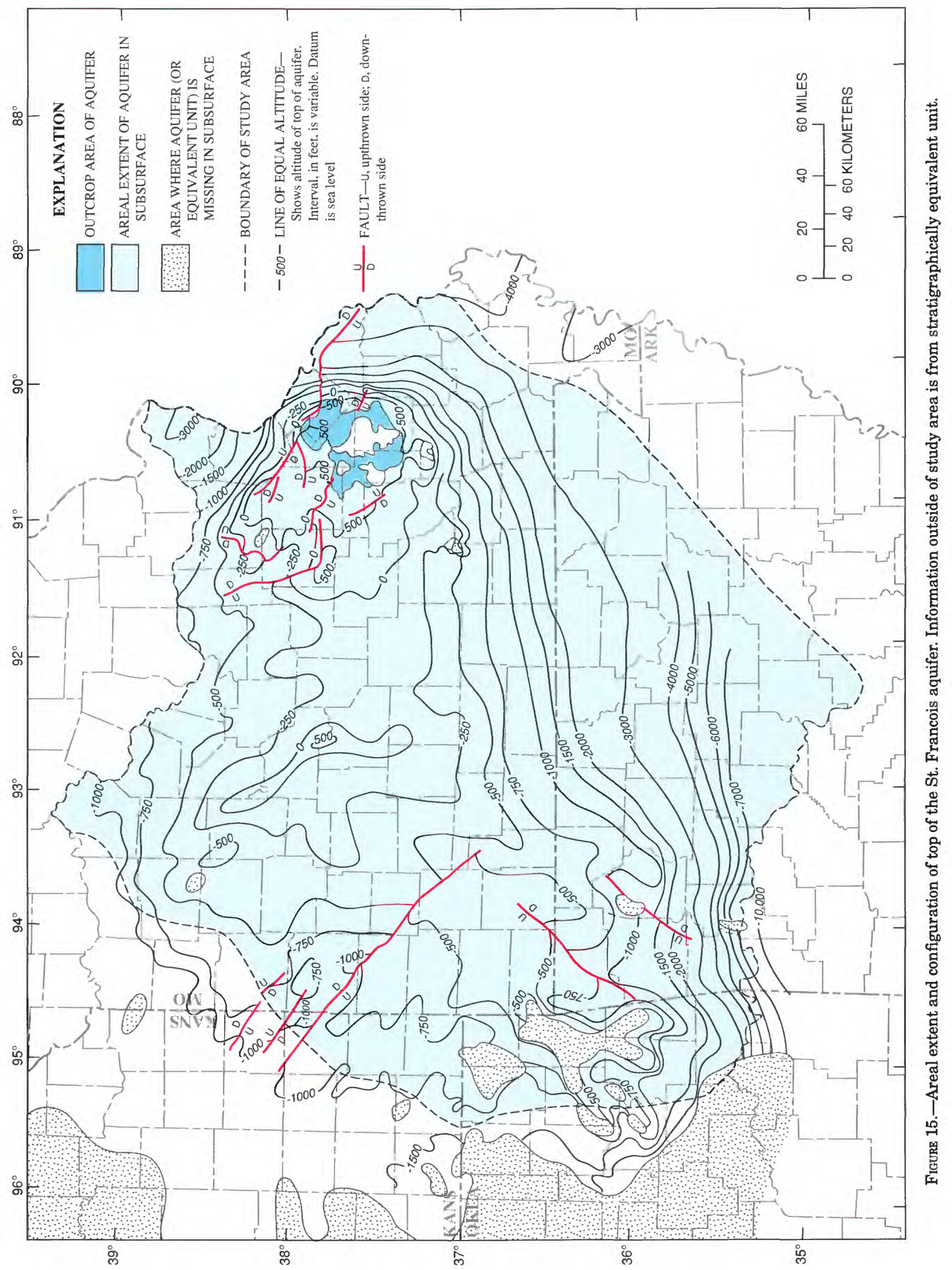




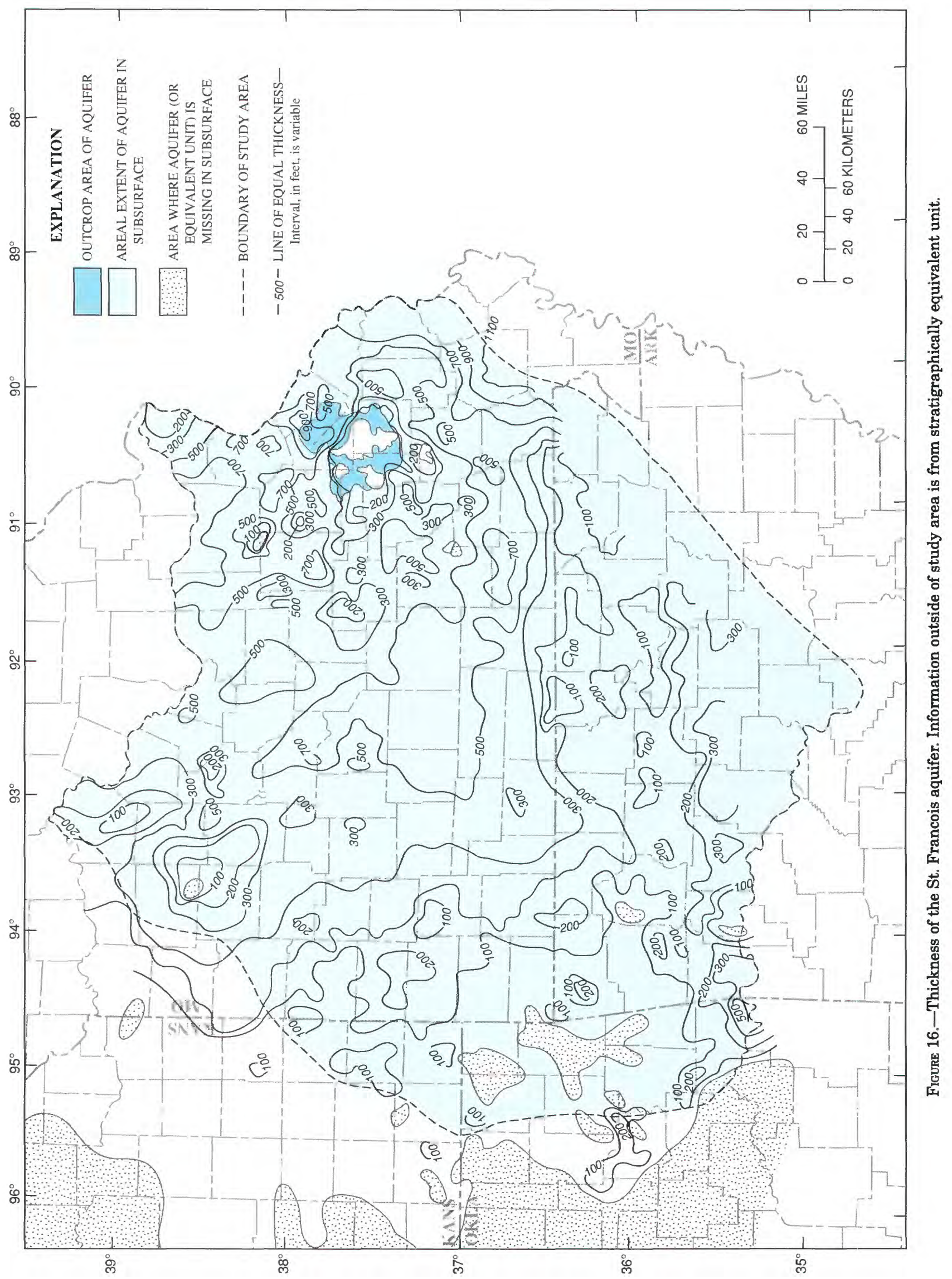


Caplan (1960), on the basis of samples from six wells in northwestern Arkansas, as a loosely cemented, subangular to rounded quartz sandstone that occasionally is dolomitic. Fragments of feldspar from the underlying Precambrian rocks are encased in the sandstone at its base. It is probable that the permeability of the Lamotte Sandstone is lower south of the Boston Mountains where the unit is buried beneath thousands of feet of younger sediments (fig. 14).

Near the St. Francois Mountains, the overlying Bonneterre Dolomite is predominantly a coarsegrained dolostone containing numerous small cavities and resting on a sandy dolostone basal unit. The lithology of the Bonneterre in this area is indicative of a barrier-reef facies that developed in shallow water offshore from islands of Precambrian rock that rose above the Cambrian sea. The offshore facies of the Bonneterre Dolomite predominantly was a finegrained limestone with some clastic material, mainly shale (Gerdemann and Myers, 1972). The Bonneterre Dolomite probably is more permeable in the reef and back-reef facies adjacent to the St. Francois Mountains than in the offshore facies where the unit is finer grained and contains a larger fraction of shale.

The western one-quarter of the aquifer is composed of the Reagan Sandstone, a near-shore facies of the Lamotte Sandstone, Bonneterre Dolomite, and Davis Formation (Kurtz and others, 1975). The Reagan Sandstone generally is a poorly sorted sandstone containing small quantities of silt and shale. Little is known about the geohydrologic properties of this sandstone because few water-supply wells are drilled deep enough to penetrate the sandstone. However, information from a well drilled in Jasper County, Missouri (fig. 3), indicates that the Reagan Sandstone probably is hydrologically similar to the moderately permeable Lamotte Sandstone.

Estimates of the hydraulic conductivity of the St. Francois aquifer were made using specific-capacity data. The method that was used to estimate the hydraulic conductivity can be divided into two procedures. First, because most wells do not penetrate the entire thickness of an aquifer, it is necessary to use a correction factor to determine the specific capacity of each well as if it penetrated the entire thickness of the aquifer. The specific-capacity data from partially penetrating wells were corrected to values one would expect from fully penetrating wells using a derivation presented by Todd (1959). Second, the corrected specific-capacity data were used with the steady-state Thiem equation or the Jacob approximation to the Theis equation (Lohman, 1979) to estimate the aquifer transmissivity. Transmissivity values were con- verted to hydraulic conductivity by dividing by the aquifer thickness.

The estimated hydraulic conductivity of the St. Francois aquifer in the immediate vicinity of the St. Francois Mountains ranges from as great as $1 \times 10^{-4}$ foot per second to less than $1 \times 10^{-6}$ foot per second. The hydraulic conductivity is greater in the St. Francois Mountains and decreases radially away from the mountains. Data are insufficient to estimate the distribution of hydraulic conductivity beyond the vicinity of the St. Francois Mountains, primarily because wells away from the St. Francois Mountains that penetrate the confined aquifer are also open to other aquifers.

Warner and others (1974), using water-level data from observation wells and the Jacob modified nonequilibrium formula (Lohman, 1979), estimated the transmissivity of the combined Lamotte Sandstone and Bonneterre Dolomite at three mines near the eastern edge of the St. Francois Mountains as $1.8 \times 10^{-3}, 5.4 \times 10^{-3}$, and $3.0 \times 10^{-4}$ foot squared per second. Corresponding values of estimated storage coefficients were $0.0085,0.0043$, and 0.0026 (dimensionless). Using estimated thicknesses of the St. Francois aquifer at these mine locations, we estimated hydraulic conductivities of the aquifer to be $6.2 \times 10^{-6}, 1.4 \times 10^{-5}$, and $4.5 \times 10^{-7}$ foot per second, respectively. The corresponding projections of the probable hydraulic conductivity at these mine sites, as determined from contoured specific-capacity data, are $1 \times 10^{-4}, 7 \times 10^{-6}$, and $2 \times 10^{-6}$ foot per second. The differences in the estimates are not so large as they appear when one considers the sparsity of the specificcapacity data for the aquifer and the differences in the techniques used for these estimates.

Recharge, Ground-Water Flow, and Discharge

Ground-water levels in the vicinity where the St. Francois aquifer crops out are mainly controlled by topographic features (fig. 17). The altitude of the potentiometric surface varies from more than 1,100 feet above sea level in the upland areas to less than 600 feet above sea level in the major river valleys. Depth to water in the outcrop area ranges from a few feet in the valleys to as much as 150 feet in the highlands. Ground water discharges to the St. Francois and Black Rivers to the south and the Big River to the north. The head data indicate that ground water discharges toward these rivers even in the region immediately surrounding the outcrop area, where the aquifer is confined (Imes, 1990b). In this region the leakance of the overlying confining unit is large 

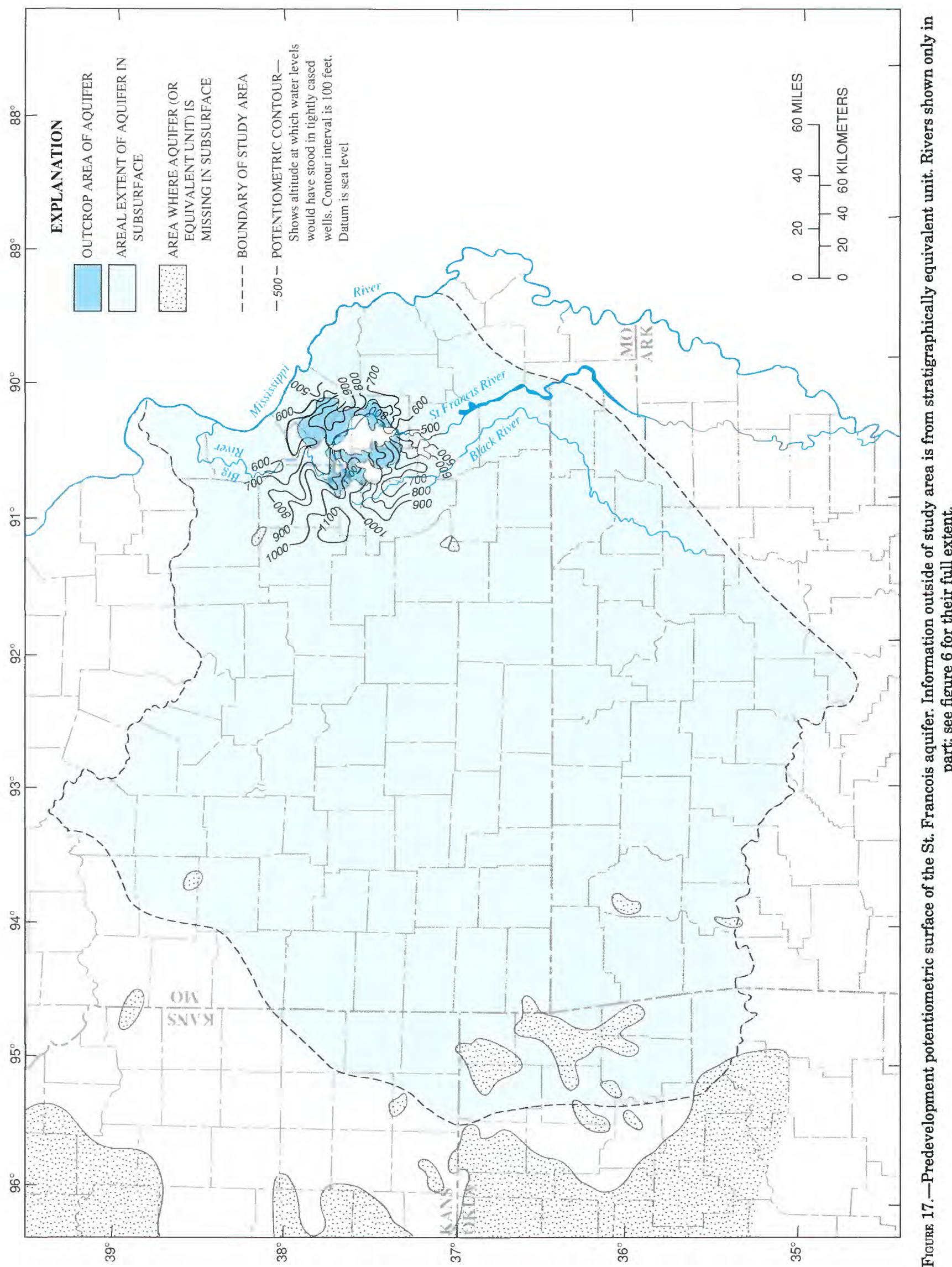
enough so that heads in the St. Francois aquifer are affected by topographic relief.

Few wells are open to the St. Francois aquifer beyond the vicinity of the St. Francois Mountains, and the wells that do penetrate the St. Francois aquifer also are open to the overlying Ozark aquifer. Therefore, heads observed in these wells are composite heads, and little is known about heads in the St. Francois aquifer beyond the vicinity of the St. Francois Mountains. Because the St. Francois aquifer is seldom used for withdrawals of large quantities of ground water, the present-day potentiometric surface of the aquifer probably varies little from the predevelopment potentiometric surface. An exception to this statement occurs along the Viburnum Trend lead ore deposits on the western flank of the St. Francois Mountains. Pumpage to dewater lead-mine shafts has caused large drawdowns in the vicinity of the mining area.

Chemical Qualtiy of Ground Water

Bicarbonate is the dominant anion in samples of ground water from wells near the outcrop area of the aquifer (fig. 18; table 2; Imes and Davis, 1990a). Calcium and magnesium are the dominant cations; in most of this area the concentration of the dominant cation does not exceed 50 percent. Locally, the water type can be calcium bicarbonate or magnesium bicarbonate. The water type in wells located a few miles northwest and southwest of the outcrop area is sodium bicarbonate or bicarbonate with sodium as the dominant cation.

Near the St. Francois Mountains the dissolved-solids content of ground water in the aquifer varies from less than 100 to more than 400 milligrams per liter (fig. 19; Imes and Davis, 1990a). In general, areas of larger concentration seem to be located southwest and northwest of the mountains. Elsewhere, the dissolved-solids concentration ranges from about 200 to 400 milligrams per liter except at the easternmost well location, where the measured dissolved-solids concentration was less than 100 milligrams per liter. Dissolved-solids concentrations in water from the few wells that are open to the aquifer and overlying geohydrologic units in Phelps, Pettis, and Jasper Counties, Missouri (fig. 3), are not large, but the actual concentrations in water from the St. Francois aquifer cannot be determined.

The concentration of chloride ions in water from the St. Francois aquifer in the vicinity of the St. Francois Mountains varies from less than 5 milligrams per liter to more than 60 milligrams per liter (fig. 19). Water samples containing the larger concentrations were obtained from wells located northwest and southwest of the mountains. Ground water to the northeast of the mountains generally contains chloride concentrations of less than 10 milligrams per liter, but a small area in southwest St. Francois County (fig. 3) contains more than 10 milligrams per liter.

The sulfate concentrations in ground water vary in a pattern similar to that shown by the chloride ions (fig. 19). The wells that contain larger sulfate concentrations are located northwest $(38 \mathrm{mg} / \mathrm{L})$ and southwest $(60 \mathrm{mg} / \mathrm{L})$ of the St. Francois Mountains and in southwest St. Francois County $(150 \mathrm{mg} / \mathrm{L})$.

The concentrations of dissolved solids, chloride, and sulfate reported above and mapped in figure 19 are based on water samples from a few wells located in a small area in and near the outcrop area of the aquifer. They probably do not reflect ion concentrations far from the St. Francois Mountains where the aquifer is confined and deeply buried.

\section{ST. FRANCOIS CONFINING UNIT}

The St. Francois confining unit, the lower confining unit in the Ozark Plateaus aquifer system, retards the flow of ground water between the more permeable St. Francois aquifer and the overlying Ozark aquifer. The confining unit is composed of shale, siltstone, dolostone, and limestone. It is missing in the St. Francois Mountains but is nearly continuous in the subsurface from its outcrop area around the St. Francois Mountains to the boundaries of the study area. Three Upper Cambrian geologic formations, the Davis Formation and the Derby and Doe Run Dolomites (table 1), form the confining unit.

\section{Structural Features}

Erosion of the Ozark dome has exposed the St. Francois confining unit at land surface in a thin, nearly circular band around the St. Francois Mountains (fig. 12). The total outcrop area is about 400 square miles and surrounds a central core of older rocks where the unit is missing. Northeast, east, and southeast of the outcrop area, the confining unit dips steeply into the subsurface (fig. 20; Imes, 1990c). The dip is greatest to the east, where it can exceed 150 feet per mile. From an altitude of 1,000 feet above sea level in the outcrop area at the eastern edge of the St. Francois Mountains, the confining unit plunges into the subsurface to an altitude of more than 


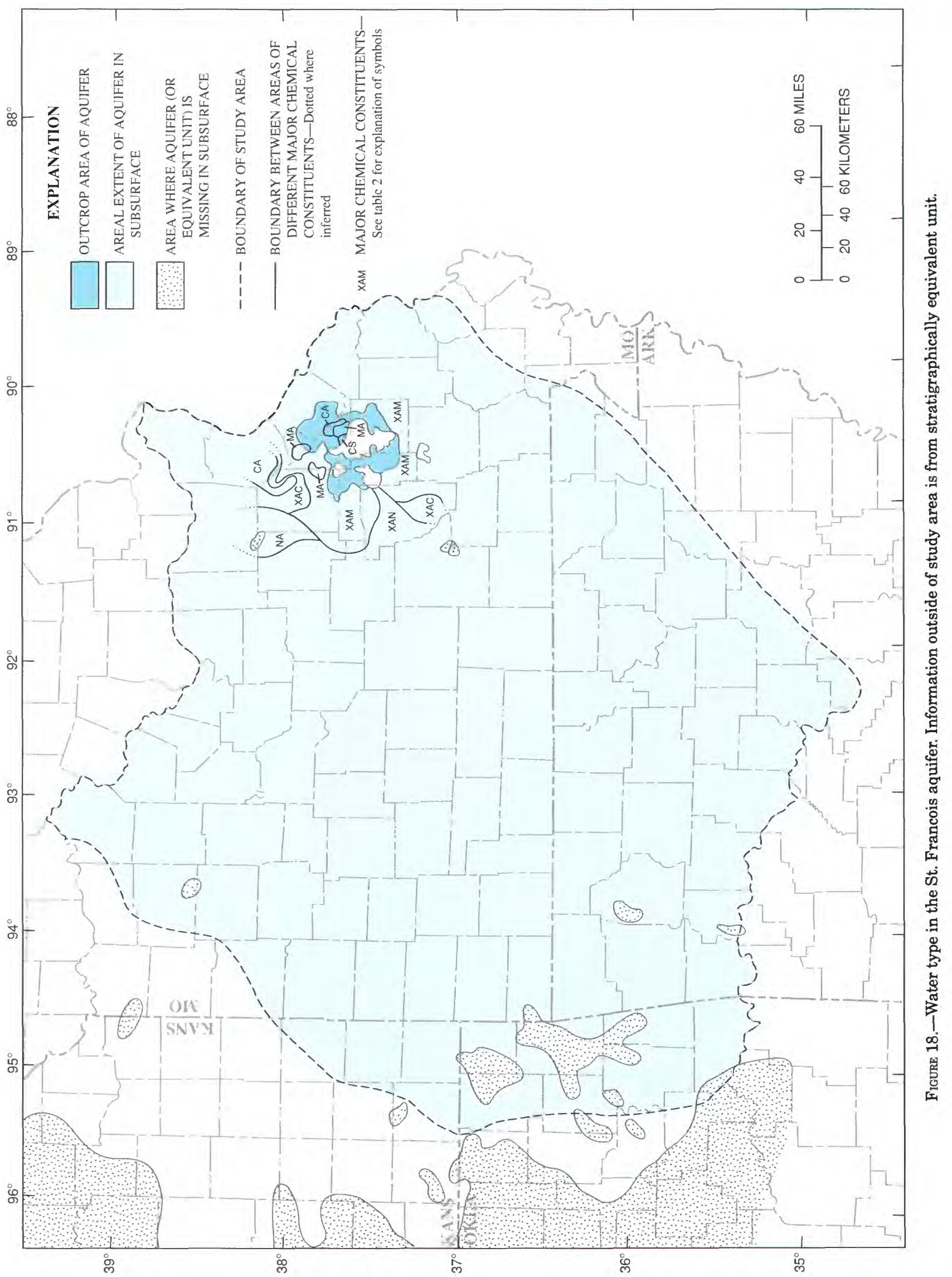


TABLE 2.-Explanation of symbols used in maps of major chemical constituents

[Two-letter code is used to designate the cation and anion present in concentrations larger than 49.99 percent. If a cation or anion is not present in a concentration larger than 49.99 percent, the species is designated by $X$ and the cation or anion existing in the largest concentration is listed as a third symbol. Thus, XAN indicates a bicarbonate water with no cation present in a concentration larger than 49.99 percent, but with sodium present in the largest concentration of the three cations]

\begin{tabular}{lllll}
\hline & \multicolumn{4}{c}{ Anion } \\
\cline { 2 - 5 } Cation & Bicarbonate & Chloride & Sulfate & Mixed anion \\
\hline Calcium & CA & CC & CS & CX (A, C, S) \\
Magnesium & MA & MC & MS & MX (A, C, S) \\
Sodium & NA & NC & NS & NX (A, C, S) \\
Mixed cation & XA (C, M, N) & XC (C, M, N) & XS (C, M, N) & XX \\
\hline
\end{tabular}
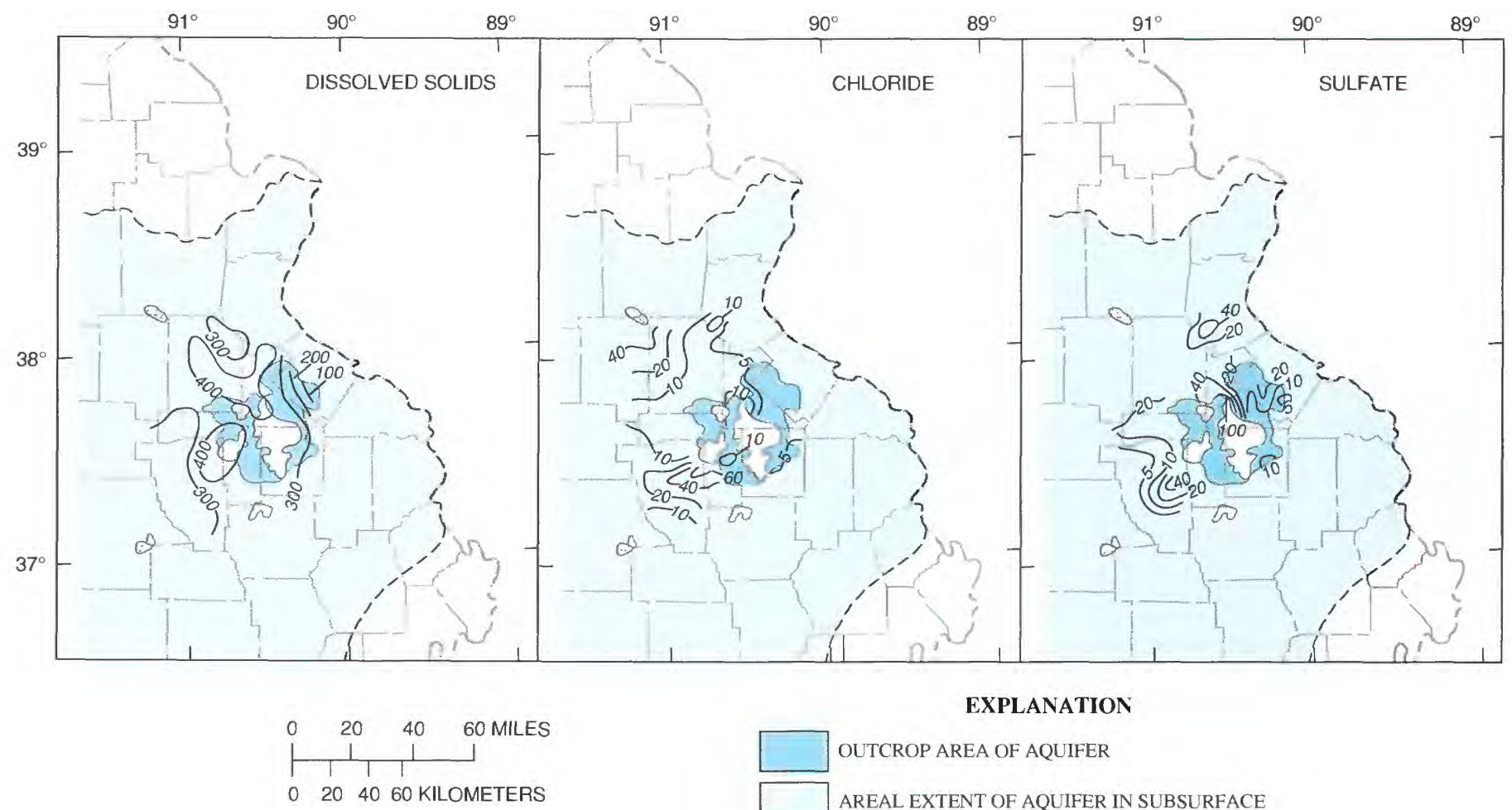

EXPLANATION

0204060 KILOMETERS

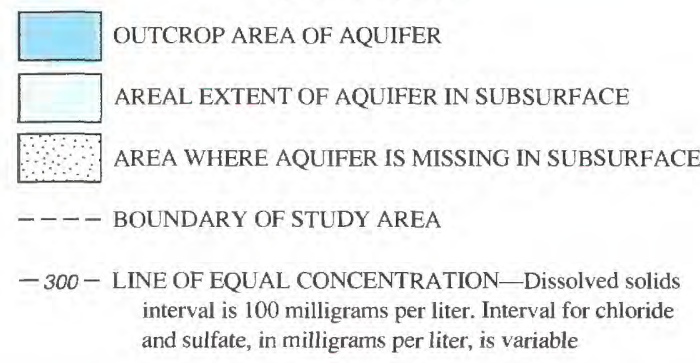

Figure 19.-Dissolved-solids, chloride, and sulfate concentrations in ground water from the St. Francois aquifer. 


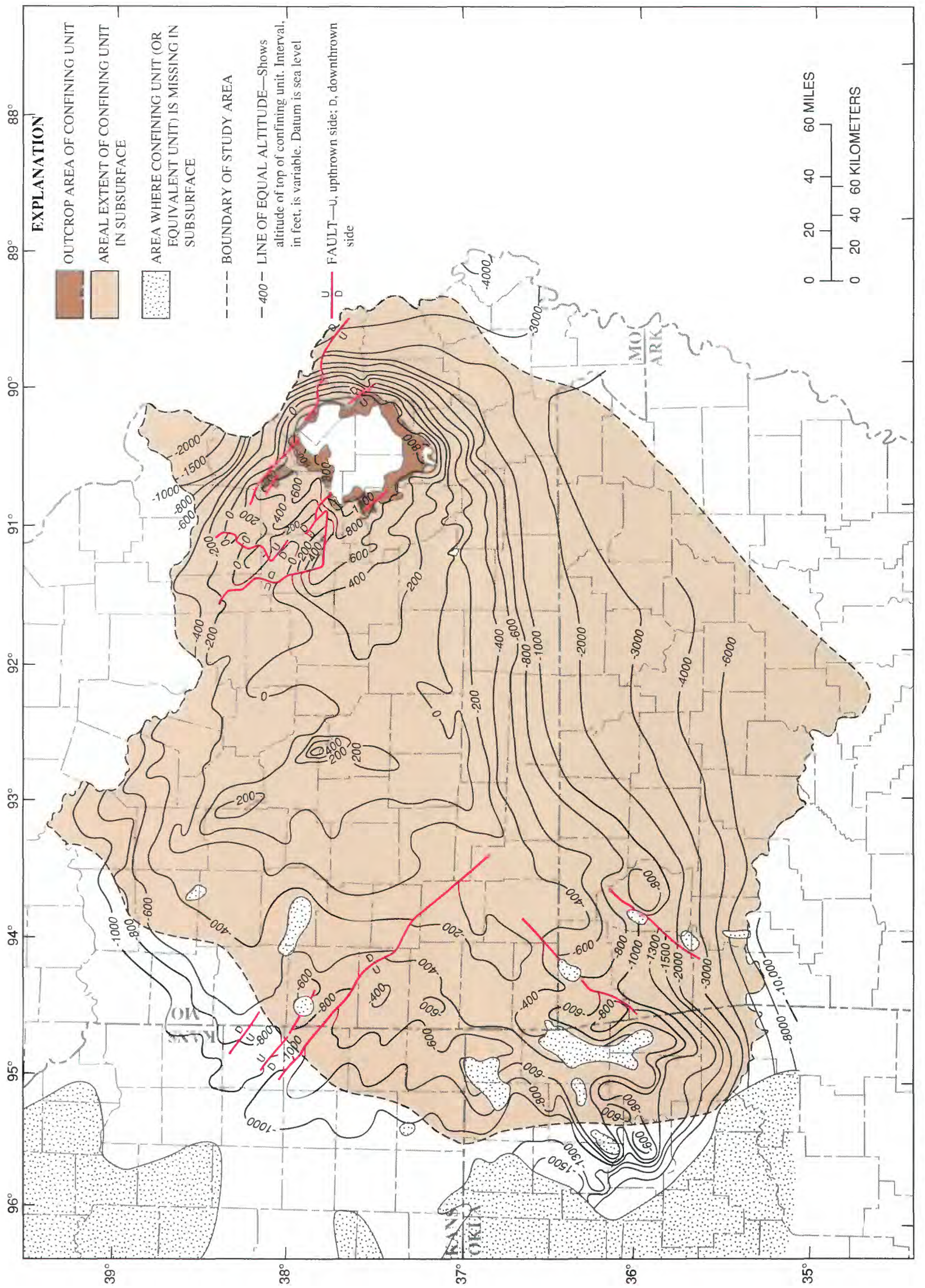

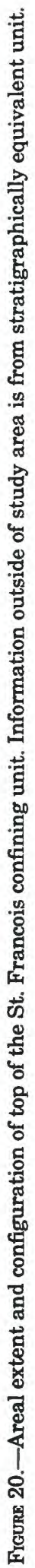


3,000 feet below sea level at the eastern edge of the Ozark Plateaus province. West of the St. Francois Mountains, the unit dips less steeply into the subsurface, and the top of the unit forms a broad, gently sloping subsurface plateau, broken by several small depressions and hills. The altitude of the top of the unit is lower than 7,000 feet below sea level beneath the Arkansas River at the southern boundary of the Ozark Plateaus aquifer system.

The confining unit is missing in the subsurface from several small isolated areas in western Missouri, northeastern Oklahoma, and northwestern Arkansas (fig. 20). The altitude of the top of the unit generally increases near areas where the unit is missing in northeastern Oklahoma. The increase is consistent with the existence of uplifted Precambrian knobs. In contrast, the altitude of the top of the unit in western Missouri and northwestern Arkansas changes little near areas where the unit is missing. These latter areas may, therefore, represent areas of nondeposition. Most of the areas where the confining unit is missing coincide with areas where the underlying St. Francois aquifer is absent (fig. 14).

\section{THICKNESS}

The St. Francois confining unit, as determined from well-log data, ranges from 0 to 730 feet thick (fig. 21; Imes, 1990c). This semipermeable rock unit thins against the flanks of the St. Francois Mountains in southeastern Missouri and near the local areas where it is missing in the southwestern and western parts of the study area. Beyond its outcrop area the thickness of the confining unit ranges from 200 to 400 feet throughout much of the Salem Plateau. The thickness of the unit exceeds 600 feet beneath the northwest edge of the Mississippi Alluvial Plain. West of the Salem Plateau the unit gradually decreases in thickness until stratigraphically equivalent geohydrologic units pinch out a few miles west of the Ozark Plateaus aquifer system in eastern Kansas and northeastern Oklahoma (Kurtz and others, 1975). In the southwestern part of the study area the unit is, for the most part, less than 100 feet thick. In northern Arkansas the unit generally varies between 100 and 400 feet thick, but is 730 feet thick in Madison County, Arkansas (fig. 3). This area of increased thickness coincides with a deep depression in the Precambrian surface.

The Davis Formation is absent from the St. Francois confining unit at isolated locations in Saline and Douglas Counties, Missouri (fig. 3), but it is part of the unit elsewhere. The Davis thins to the southwest because lower sediments of the Davis become more clastic and grade into Reagan Sandstone (Thacker, 1974), a formation included in the underlying St. Francois aquifer. The Derby and Doe Run Dolomites are uniform in thickness and are part of the confining unit throughout the study area.

Lithology and Geohydrologic Properties

The Davis Formation generally contains a large percentage of clastic rocks and has the most continuous shale unit in the entire sequence of Cambrian strata. Clastic rocks usually are more prevalent near the base of the Davis Formation, and carbonate rocks are more predominant near the top. The lithology of the Davis Formation has been defined in more detail in the vicinity of the St. Francois Mountains where numerous mineral test holes have penetrated the formation. In this area, the lower part of the Davis formation is a coarse-grained, massively bedded dolostone with a significant shale content and a welldefined zone of conglomerate cemented with dolomite (Fletcher, 1974). The upper part of the Davis Formation generally is not so thickly bedded, is more fine grained, and does not contain as much shale. A massive, coarse-grained dolostone tops the upper part. Locally, the Davis Formation may contain large quantities of sand and silt. The distribution of shale is not uniform, and in some areas sand may be the dominant clastic component. It is expected that the effectiveness of the Davis Formation as a confining unit may be impaired in these sand-rich areas. In the southwest part of the Ozark Plateaus, the sand-toshale ratio of the Davis Formation increases and the lower part of the formation becomes the Reagan Sandstone.

The Derby and Doe Run Dolomites generally have a smaller shale content than the Davis Formation; however, locally they may contain nearly as much shale and silt as the Davis Formation. The Derby and Doe Run Dolomites are regarded as a transition unit, dividing Cambrian sedimentary rocks with a large clastic content below from sedimentary rocks that contain only small quantities of clastic material above.

The shale content of a geohydrologic unit commonly is used as a measure of the effectiveness of the unit in restricting leakage. Therefore, maps of the shale content (in percent of total thickness) and net shale thickness of the St. Francois confining unit are presented in figures 22 and 23 . However, it must be emphasized that the presence or absence of shale is not the only determining factor in assessing the 


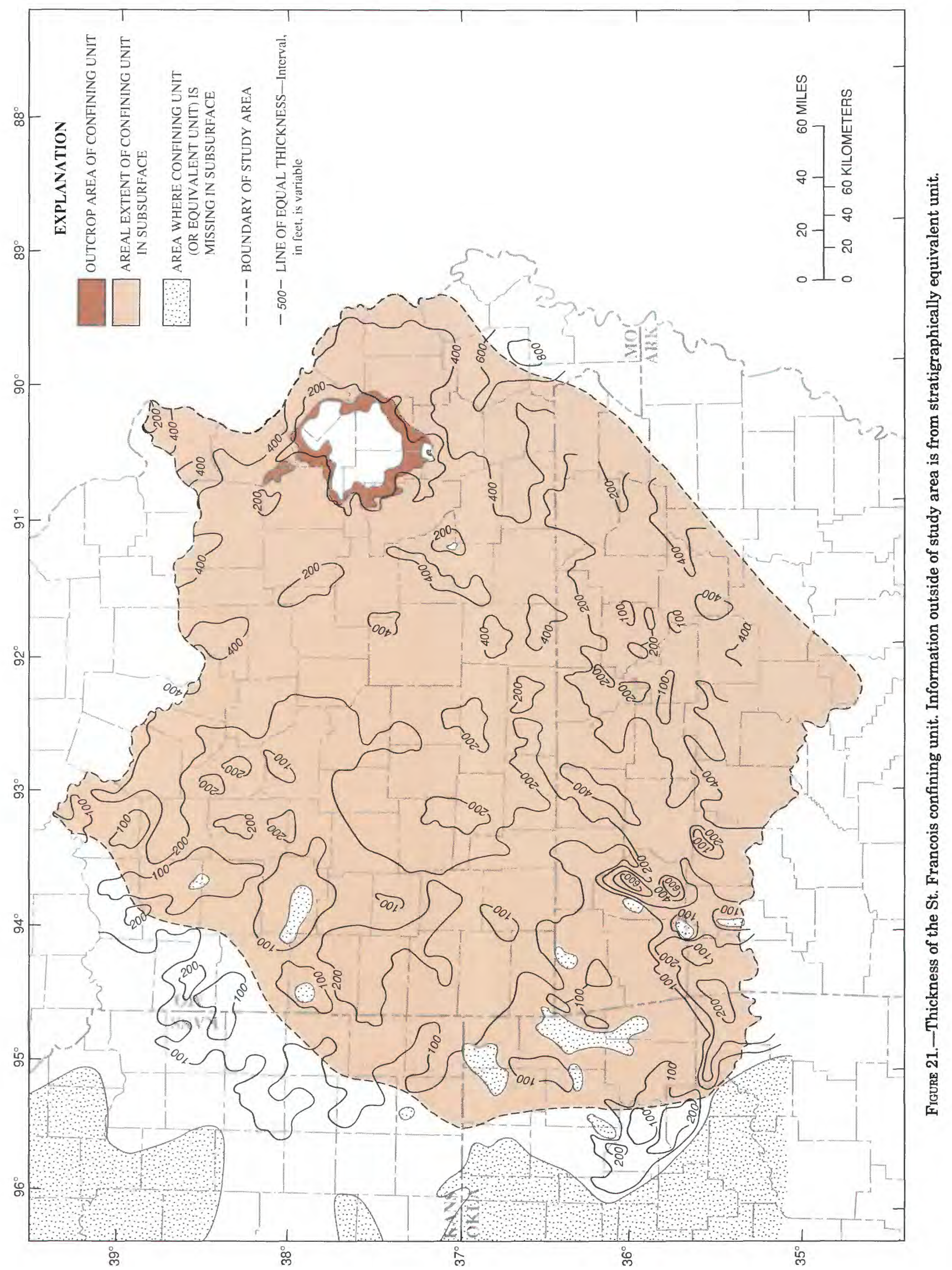




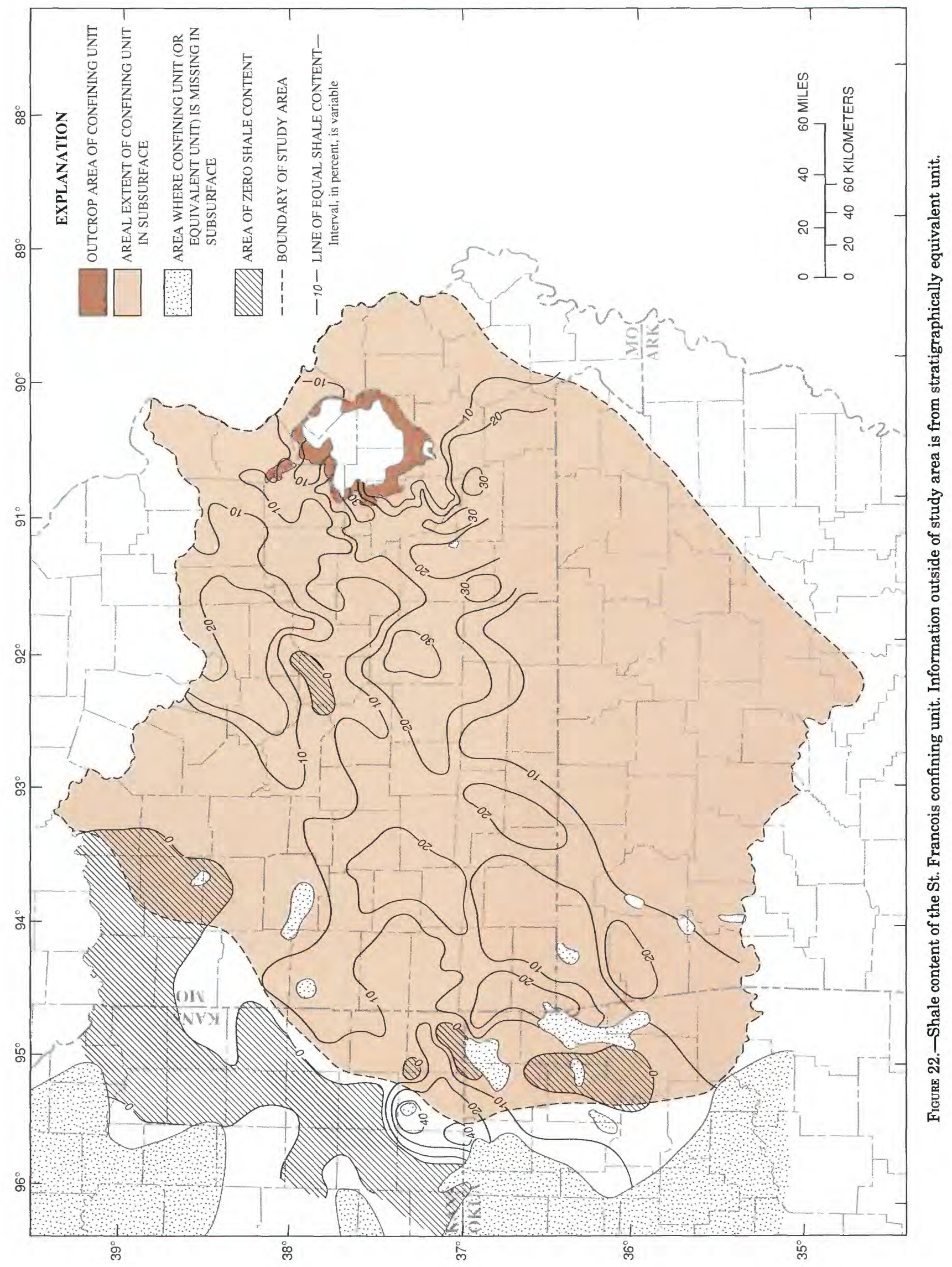




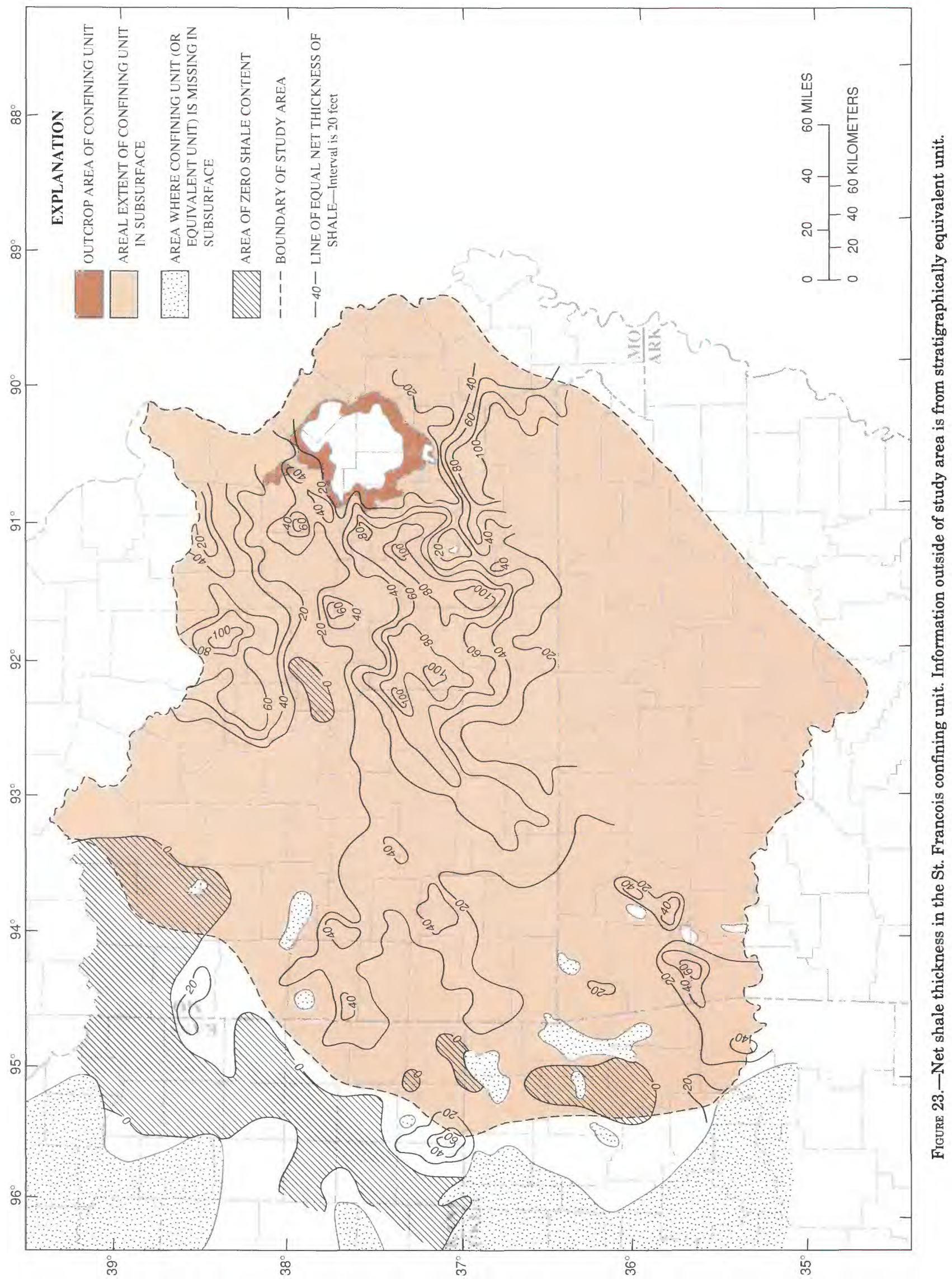


effectiveness of a carbonate and clastic geohydrologic unit as a confining unit. Other factors include the primary and secondary permeability of the carbonate and the presence or absence of fractures.

The shale content of the St. Francois confining unit ranges from 0 to about 40 percent (fig. 22; Imes, 1990c). In the northern half of the study area, the shale content of the unit is less than 10 percent along a band extending west from the northern edge of the St. Francois Mountains. To either side of this band, the shale content increases to more than 20 percent. Shale content locally exceeds 30 percent in an area southwest of the St. Francois Mountains. In the southwestern part of the study area, the shale content ranges from less than 10 percent to more than 20 percent. A small area in northeastern Oklahoma is devoid of shale. Also, no shale is present throughout a large area that parallels the western boundary of the study area. No lithologic data are available for this unit in the southernmost parts of the study area.

Most of the shale in the St. Francois confining unit forms thick beds, but it also is common throughout the limestone and dolostone matrix as shale partings less than a few inches thick. The net shale thickness map (fig. 23) shows the effective shale thickness of the unit as if the shale existed in a single bed instead of being distributed throughout the unit. Generally, the net shale thickness is greater in the east where the confining unit is thicker. The net shale thickness is least, less than 20 feet, along a band stretching west from the northern edge of the St. Francois Mountains; it is greater north and south of this band. To the north the net shale thickness increases to about 100 feet near the Missouri River in the north-central part of the Salem Plateau. South of the band the net shale thickness increases to more than 100 feet locally in a region extending from Texas County, Missouri (fig. 3), to the west flank of the St. Francois Mountains. Throughout the western half of the Ozark study area, the net shale thickness generally remains less than 40 feet, except in one small locality in northwestern Arkansas where it exceeds 60 feet. In northeastern Oklahoma, the thickness generally is less than 20 feet.

Significant secondary porosity and permeability have not developed in the limestone and dolostone of the Davis Formation or in the Derby and Doe Run Dolomites. The relatively fine grained nature of the dolostones suggests that the rocks are relatively impermeable, even in areas containing little or no shale. However, there is evidence from bore-hole cores that the upper part of the Derby and Doe Run Dolomites is more permeable along a northwest- trending reef zone passing through Wright and Douglas Counties, Missouri (fig. 3). The location of the reef zone corresponds to the transition between the greater net shale content of the eastern half of the study area and the lesser net shale content of the western half (fig. 23). Because the shaly Davis Formation is absent in part of the reef, it is possible that interchange of water between the St. Francois aquifer and the overlying Ozark aquifer occurs more readily in the vicinity of the reef zone.

The authors are unaware of any quantitative measurements of the hydraulic conductivity of the St. Francois confining unit. Fletcher (1974) reports that the withdrawal of large quantities of water from the St. Francois aquifer by lead mining companies in the Viburnum Trend near the western flank of the St. Francois Mountains did not seem to significantly affect water levels in the overlying Ozark aquifer. $\mathrm{He}$ concluded that the Davis Formation forms an effective confining unit in the study area. However, he also concluded that ground-water levels were affected more severely near the major fracture zones that penetrate the confining unit. It seems, therefore, that the permeability of the St. Francois confining unit is increased near fracture zones, at least in the vicinity of the St. Francois Mountains. Also, potentiometrichead data from the underlying St. Francois aquifer indicate that water levels in the aquifer are affected by local topographic relief at distances of at least 15 miles from its outcrop area, where the aquifer is buried 300 to 800 feet deep. Thus, the permeability of the confining unit in that area is large enough to allow topographic relief to affect heads in the underlying St. Francois aquifer.

\section{OZARK AQUIFER}

The Ozark aquifer is a thick sequence of waterbearing rock, mainly dolostone, limestone, and sandstone formations, ranging in age from Late Cambrian to Middle Devonian. The water-yielding capacity of the individual formations varies, but collectively they act as a regional aquifer. Stratigraphically, the basal formation of the aquifer is the Cambrian Potosi Dolomite (table 1). In the northeastern part of the study area, the upper boundary of the aquifer coincides with the base of the Upper Ordovician Maquoketa Shale. Generally, this shale formation disconformably overlies the Kimmswick Formation, but locally it may overlie the Cape Limestone (Koenig, 1961). Many of the younger formations within the aquifer are not present in the Salem Plateau, where the aquifer crops out and is deeply eroded. West and south 
of the Salem Plateau, the Maquoketa Shale is absent, and younger, Devonian rocks are included as part of the aquifer. In this area the upper boundary of the aquifer is represented stratigraphically by the base of the Upper Devonian Chattanooga Shale.

\section{Structural Features}

The outcrop area of the Ozark aquifer is approximately coincident with the Salem Plateau (see figs. 5, 25). The Cambrian rocks that constitute the basal formations of the aquifer crop out around the core of the St. Francois Mountains and along river valleys in the Salem Plateau, most notably the Osage, Meramec, and Current Rivers (fig. 6). The rocks that form the Ozark aquifer have been removed entirely from the core of the St. Francois Mountains. Ordovician rocks, primarily the Gasconade Dolomite, the Roubidoux Formation, and the Jefferson City Dolomite, make up the largest part of the aquifer's roughly circular outcrop area, which is circumscribed by a thin ring of less permeable rocks (part of the Ozark confining unit) along much of the perimeter of the Salem Plateau (fig. 12). Surface drainage systems on the aquifer's carbonate rocks have formed severely dissected, rugged topographic features. The aquifer is broken by numerous faults and fracture systems (fig. 9; McCracken, 1971).

In the north-central part of the Salem Plateau (in and near Gasconade, Maries, and Osage Counties, Missouri, fig. 3) the aquifer is buried beneath as much as 200 feet of relatively impermeable Pennsylvanian shale. In the extreme northeastern part of the Ozark Plateaus province the aquifer dips beneath overlying geohydrologic units to a depth of 1,000 feet below land surface at the confluence of the Missouri and Mississippi River valleys (fig. 24). Along the northwest edge of the Mississippi Alluvial Plain from Jackson County, Arkansas, to Scott County, Missouri, the aquifer is covered by thick deposits of Cretaceous, Tertiary, and Quaternary sediments. More resistant rocks of the Ozark aquifer crop out as a series of isolated hills surrounded by alluvial deposits along the northwest edge of the Mississippi Alluvial Plain. In Kansas and western Missouri the aquifer dips gently into the subsurface to the west. The top of the aquifer is less than 500 feet below land surface in most of the Springfield Plateau, but is 1,000 feet deep near the western boundary of the study area. Southward from the Boston Mountains the aquifer is buried beneath thick deposits of younger rocks.

Near the western boundary of the study area the aquifer dips to the west at about 14 feet per mile (fig.
25; Imes, 1990d). The Ozark aquifer is exposed at land surface in a series of island-like outcrops (figs. $12,24)$ extending from Barry County, Missouri, to Sequoyah County, Oklahoma (fig 3). The outcrops coincide with an area in northeast Oklahoma where rocks that constitute the St. Francois confining unit and St. Francois aquifer are absent in the subsurface along a southwest extension of the Ozark uplift (figs. $14,20)$. The altitude of the top of the aquifer exceeds 1,000 feet above sea level along the northern edge of the Boston Mountains, but decreases to lower than 6,000 feet below sea level beneath the Arkansas Valley (fig. 25).

THICKNESS

The Ozark aquifer is the thickest aquifer in the study area. The aquifer rapidly thickens to the northeast, east, and south of the St. Francois Mountains and is more than 3,000 feet thick within 19 miles of its eroded area (fig. 26; Imes, 1990d). The rate of thickening radially from the mountains is much less to the northwest, where rocks that constitute the aquifer were uplifted and eroded along a northwest extension of the Ozark uplift. The aquifer thickness varies from about 800 to about 1,000 feet in this area.

In southwestern Missouri, southeastern Kansas, and northeastern Oklahoma, the aquifer thickness varies from 800 to 1,500 feet, generally increasing from northwest to southeast. The thickness is highly variable over short distances in Oklahoma, where more of the older rocks of the aquifer are present in the valleys between Precambrian hills. At one location in eastern Craig County, Oklahoma (fig. 3), where a prominent peak in the Basement confining unit rises above the subsurface plateau (fig. 13), the Ozark aquifer is only 270 feet thick.

In northern Arkansas, the aquifer becomes thicker to the south, with the exception of a small northeastsouthwest-trending area in and adjacent to Madison County (fig. 3), where it thins locally. The unit is about 1,500 feet thick near the Missouri-Arkansas border and increases to about 5,000 feet thick beneath the Arkansas River. It is less than 1,500 feet thick in the vicinity of Madison County.

Lithology and Geohydrologic Properties

The Ozark aquifer contains formations that encompass a wide range of lithologies with varying permeability and porosity. The rocks that constitute the 


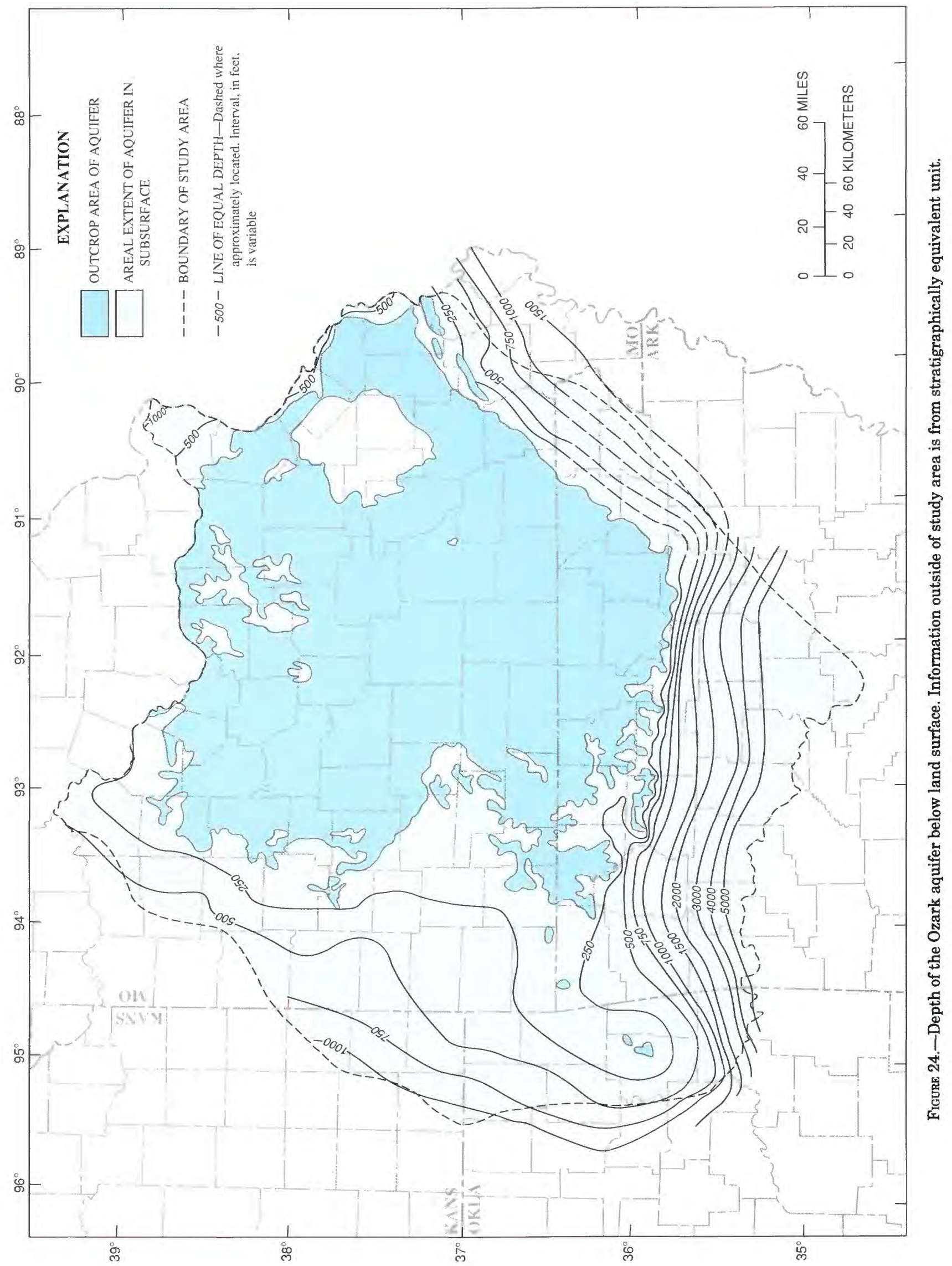




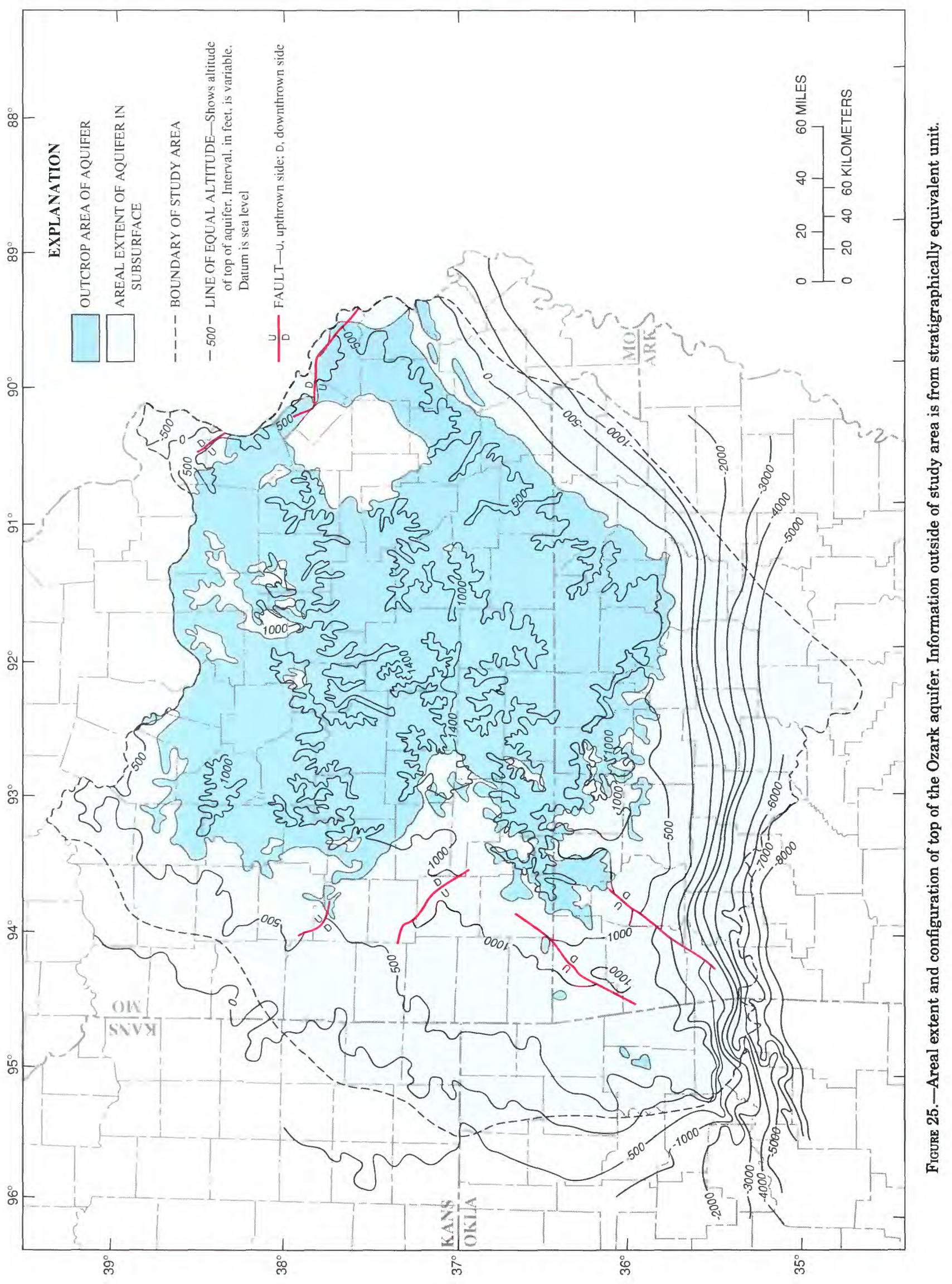




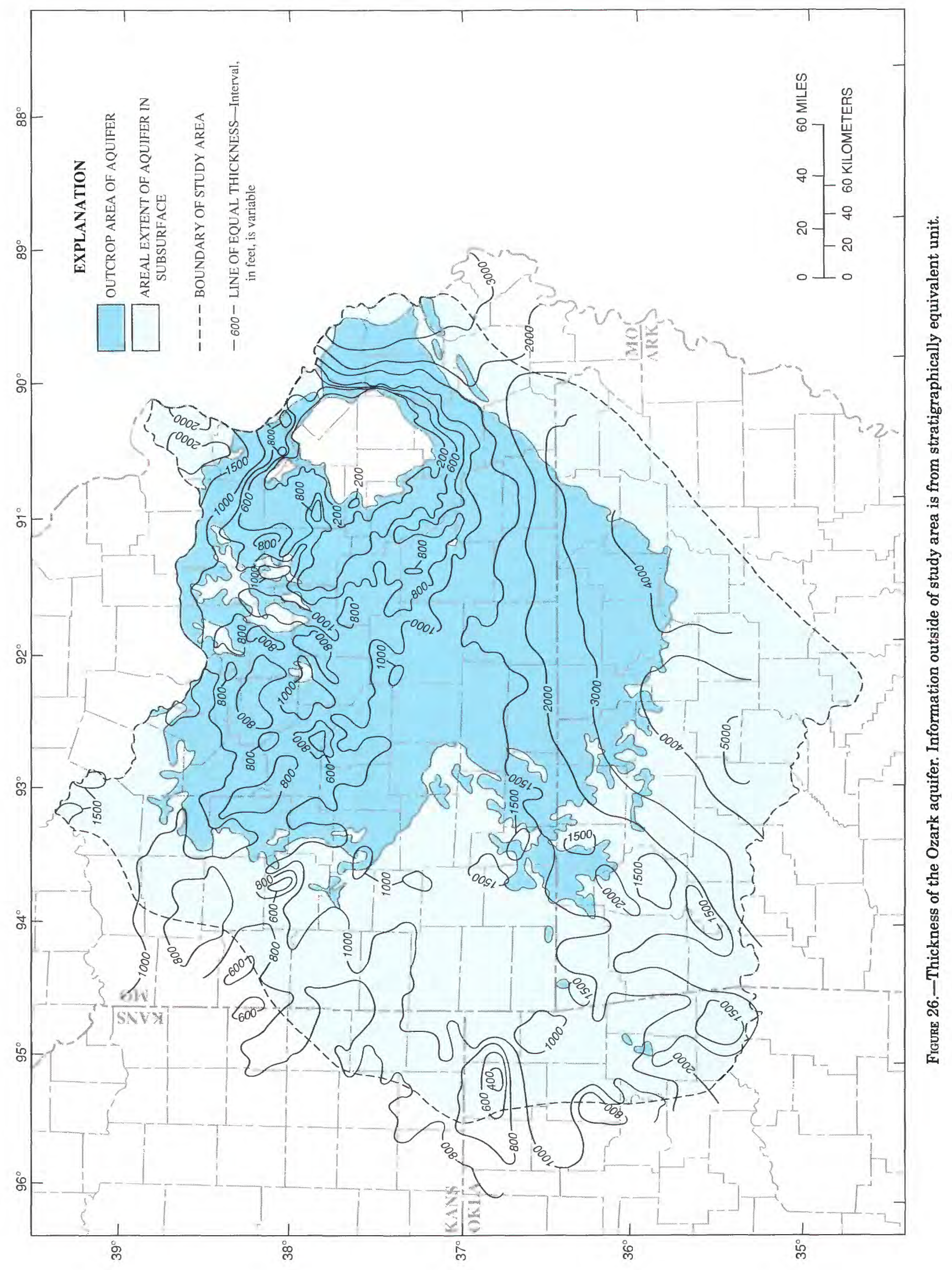


aquifer are dolostone, limestone, sandstone, chert, and shale. Dolostone is the predominant rock type in the Ozark aquifer. Dissolution of the carbonate rocks along fractures and bedding planes, including karst development, is the main process by which secondary permeability has developed in the aquifer. Sandstone is present as massive, clean, well-sorted bodies in some formations and, therefore, is relatively permeable where it is not cemented.

The rocks that collectively form the Ozark aquifer are grouped into five unnamed zones according to their regional geohydrologic properties and the relative hydraulic conductivity of adjacent zones. A significant lithologic boundary that separates the lower three zones from the upper two zones is stratigraphically coincident with the base of the Ordovician Sylvan and Cason Shales (table 1). The lithology of the rocks that form the lower three zones is predominantly dolostone and sandstone, whereas the upper two zones are predominantly limestone and shale.

The lowermost of the five zones is represented stratigraphically by rocks in the interval between the base of the Potosi Dolomite and top of the Smithville Formation (table 1). This zone contains the most permeable and porous rocks in the Ozark aquifer, is the thickest of the zones, and is present everywhere in the study area except in the St. Francois Mountains. The Potosi and Eminence Dolomites are the basal rocks of the Ozark aquifer. The Potosi Dolomite probably is, on a regional basis, the most permeable geologic unit within the aquifer and the most reliable source of water for large-capacity wells in the Ozarks. In the northern half of the study area, the coarsely crystalline, massive dolostone formation contains large quantities of druse (cavities encrusted with finely crystalline quartz) and is vuggy. Because the vugs are interconnected and solution channels are well developed in the soluble carbonate rock, the formation is very permeable. The overlying Eminence Dolomite is similar lithologically, but has less secondary porosity and permeability. In the southern and southeastern parts of the study area, the Potosi and Eminence Dolomites generally are undifferentiated (Caplan, 1960; McCracken, 1964). The characteristic quartz druse recognizable in the Potosi Dolomite to the north is missing or present only in small concentrations in the south. The permeability of these formations is less to the south where they are more deeply buried and solution channels are not well developed.

The Gasconade Dolomite and Roubidoux Formation are two of the more important water-bearing units in the area; they are especially important as sources of water in northwestern Arkansas and northeastern Oklahoma, where the Potosi Dolomite is thinner and less permeable (Lamonds, 1972; Melton, 1976). Thus, their increased importance as a source of water in the southwest is due more to their increased thickness and permeability compared to other formations of the Ozark aquifer than to an increase in their absolute permeability. The Gasconade Dolomite contains a well-defined, permeable, basal sandstone member, called the Gunter Sandstone Member. The Gunter Sandstone Member is composed of loosely cemented sandstone along a line that extends from Cooper County, Missouri, south into Boone County, Arkansas (fig. 3). The sandstone content of the member decreases and the unit becomes more dolomitic east and west of this line (Fuller and others, 1967, p. 290). The Roubidoux Formation is a loosely to well-cemented sandstone or a sandy to cherty dolostone containing several distinct sandstone bodies. The stratigraphic sequence from the Jefferson City Dolomite to the Smithville Formation consists predominantly of dolostone with small quantities of shale, chert, and sandstone; it is less permeable regionally than the stratigraphically lower rocks of the Ozark aquifer.

The second zone, in ascending order, is composed of rocks stratigraphically bounded by the base of the Everton Formation and the top of the Decorah Formation (table 1). This sequence of rock units is missing from the Salem Plateau region of the Ozarks (fig. 5). The St. Peter Sandstone probably is the most permeable and most significant water-yielding unit of this zone. It generally is a clean, round-grained, quartzose sandstone with little indication of bedding in the eastern part of the study area, but it becomes shaly, and presumably less permeable, in the western part of the study area. The underlying Everton Formation is a sandy dolostone interbedded with sandstone, limestone, and chert. Where the Everton Formation is sandstone, it is difficult to distinguish from the St. Peter Sandstone. In northwestern Arkansas, the St. Peter Sandstone and the Everton Formation are well cemented and have only slight permeability. There is evidence that the St. Peter Sandstone changes facies in the extreme southeast and becomes a sandy limestone. Dolomite and limestone beds are present in the St. Peter Sandstone in the south. The Burgen Sandstone of northeastern Oklahoma is lithologically similar to, and correlative with, the St. Peter Sandstone (Huffman, 1958) and, like the St. Peter Sandstone, is permeable. Of remaining formations in this zone, the Joachim Dolomite and Plattin Limestone are moderately permeable dolostone and limestone with small quantities of shale and sandstone. The Decorah Formation, limited to extreme eastern Missouri, primarily is shale and is not permeable. 
The third zone is represented by rocks in the stratigraphic sequence from the base of the Kimmswick Limestone to the top of the Cape Limestone (table 1; Koenig, 1961). These rocks are limited to the extreme northeastern and western parts of the study area. The rocks of this zone are predominantly limestone. Significant secondary porosity and permeability have not developed.

The fourth and fifth zones include the sequence of formations in the stratigraphic interval bounded by the base of the Sylvan and Cason Shales and the base of the Chattanooga Shale (table 1), which is the stratigraphic top of the Ozark aquifer. The formations in these zones are not present in the northeastern part of the study area. The fourth zone contains the nearly impermeable Sylvan Shale of Oklahoma and the Cason Shale of Arkansas. These formations are distinct shale units that contain only small quantities of dolomitic sandstone. The fifth zone includes Silurian and Devonian limestone and chert formations that are limited to the northwestern and southern parts of the study area. Rocks of the fifth zone are more permeable than rocks of the fourth zone but are relatively impermeable in comparison with the three lower zones. The generally small permeability of the fifth zone reflects a lack of secondary permeability, such as solutionchannel development. The Penters Chert is the thickest and probably most permeable of these rocks in Arkansas. The dense chert formation is fractured and brecciated throughout northern Arkansas (Wise and Caplan, 1979).

The Ozark aquifer is used in most of the study area as a source of water for both public and domestic consumption. Consequently, many wells have been constructed in the aquifer, and there is a considerable quantity of specific-capacity data available for the aquifer. The hydraulic conductivity of the Ozark aquifer was estimated from these specific-capacity data. Most of the wells that penetrate the aquifer are open to several zones. The hydraulic-conductivity estimates are treated as if they were valid for the entire thickness of the aquifer. No attempt has been made to determine the hydraulic conductivity of the individual zones. However, it is possible to make some general statements concerning the hydraulic properties of the zones estimated on the basis of specific-capacity data. Generally, specific-capacity data in the Salem Plateau reflect the hydraulic properties of the thick lowermost zone. In the southwest and south (Boston Mountains), the data are most representative of the Gasconade Dolomite and Roubidoux Formation of the lowermost zone. Data in the extreme northeastern part of the study area are mainly derived from wells that penetrate the second and third zones.
The estimated hydraulic conductivity of the Ozark aquifer varies from more than $1.0 \times 10^{-3}$ foot per second to less than $1.0 \times 10^{-8}$ foot per second (fig. 27). The hydraulic conductivity north of the northernmost regional ground-water divide (line of dots on fig. 27) varies from about $1.0 \times 10^{-5}$ foot per second to about $1.0 \times 10^{-3}$ foot per second. The areas of greatest hydraulic conductivity are concentrated along an eastwest line from Vernon County, Missouri, to the northern edge of the St. Francois Mountains, and along the Missouri River from Moniteau County to St. Louis County, Missouri (fig. 3). The Missouri River alluvium is in contact with the Ozark aquifer along this reach. The hydraulic conductivity generally decreases south of the ground-water divide. Near the southern boundary of the study area, the hydraulic conductivity decreases to less than $1.0 \times 10^{-8}$ foot per second.

Recharge, Ground-Water Flow, and Discharge

Mapping the potentiometric surface of an aquifer requires the assumption that the hydraulic head does not vary with depth. This assumption is not valid in an aquifer as thick and lithologically complex as the Ozark aquifer. Vertical head differences in the aquifer tend to be masked by the fact that most head data are measured in wells that are open to at least several hundred feet of the aquifer. Thus, the measured heads are a weighted average of the heads in the various lithologic units that are open to the well. The variation of head with depth in the Ozark aquifer generally is not large in comparison to the variation of head laterally in the aquifer, so the potentiometric surface map constructed for the Ozark aquifer (fig. 28) probably is a good representation of the lateral head distribution in the aquifer.

Ground water in the Ozark aquifer is unconfined in the Salem Plateau (fig. 12), and the potentiometric surface of the aquifer is strongly influenced by the major topographic features of the plateau. The altitude of the potentiometric surface along the northernmost regional ground-water divide (fig. 10) generally ranges from 1,200 to 1,400 feet (fig. 28; Imes, 1990d). Many divides of lesser regional importance parallel the highland areas between the major river valleys of the Salem Plateau (fig. 6). The altitude of the potentiometric surface in these upland areas varies considerably but generally ranges between 1,000 and 600 feet. Ground-water movement in the Salem Plateau is from the upland areas between major rivers and streams toward the valleys where the water discharges as stream base flow. Regional ground-water movement 


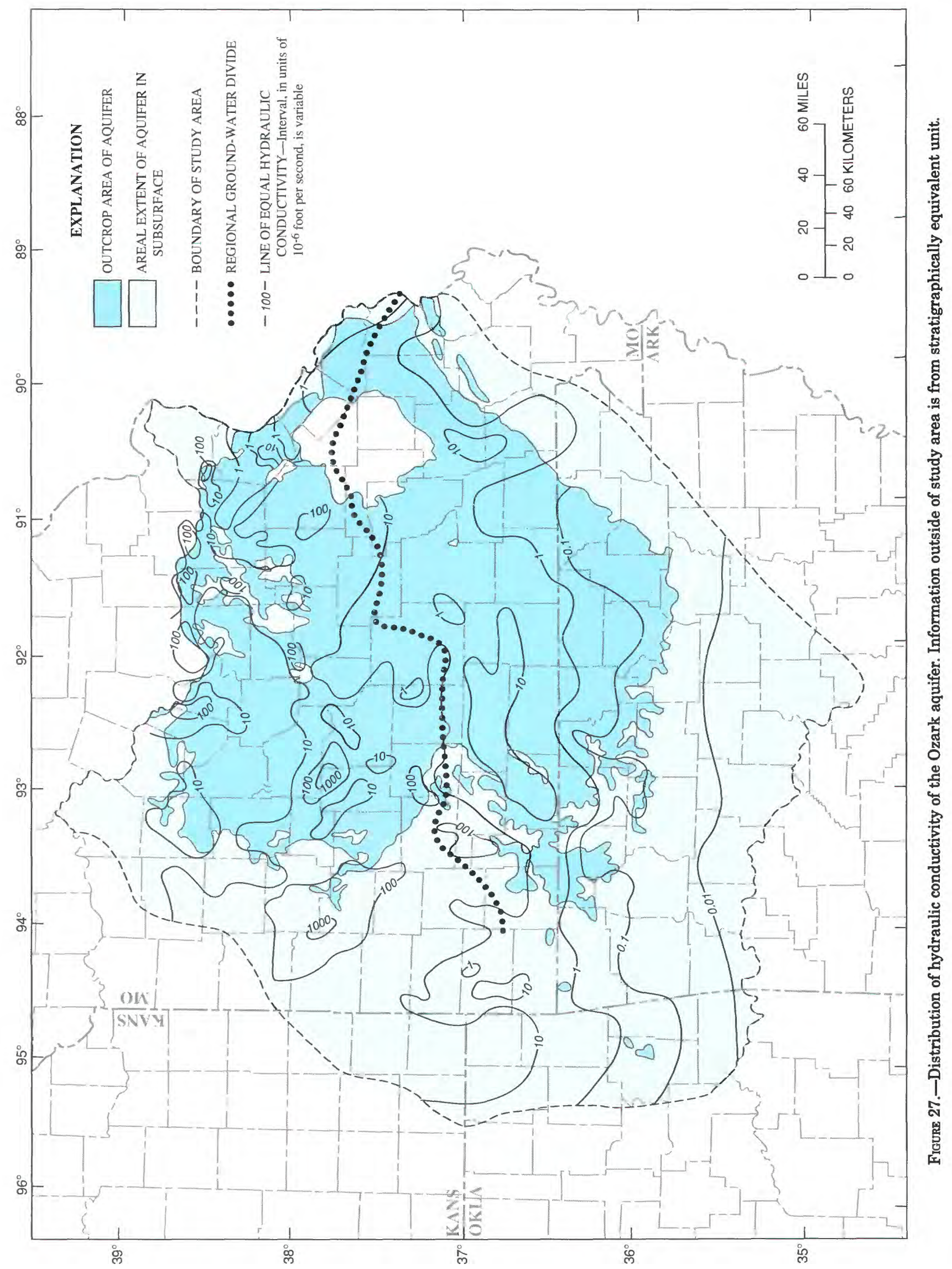




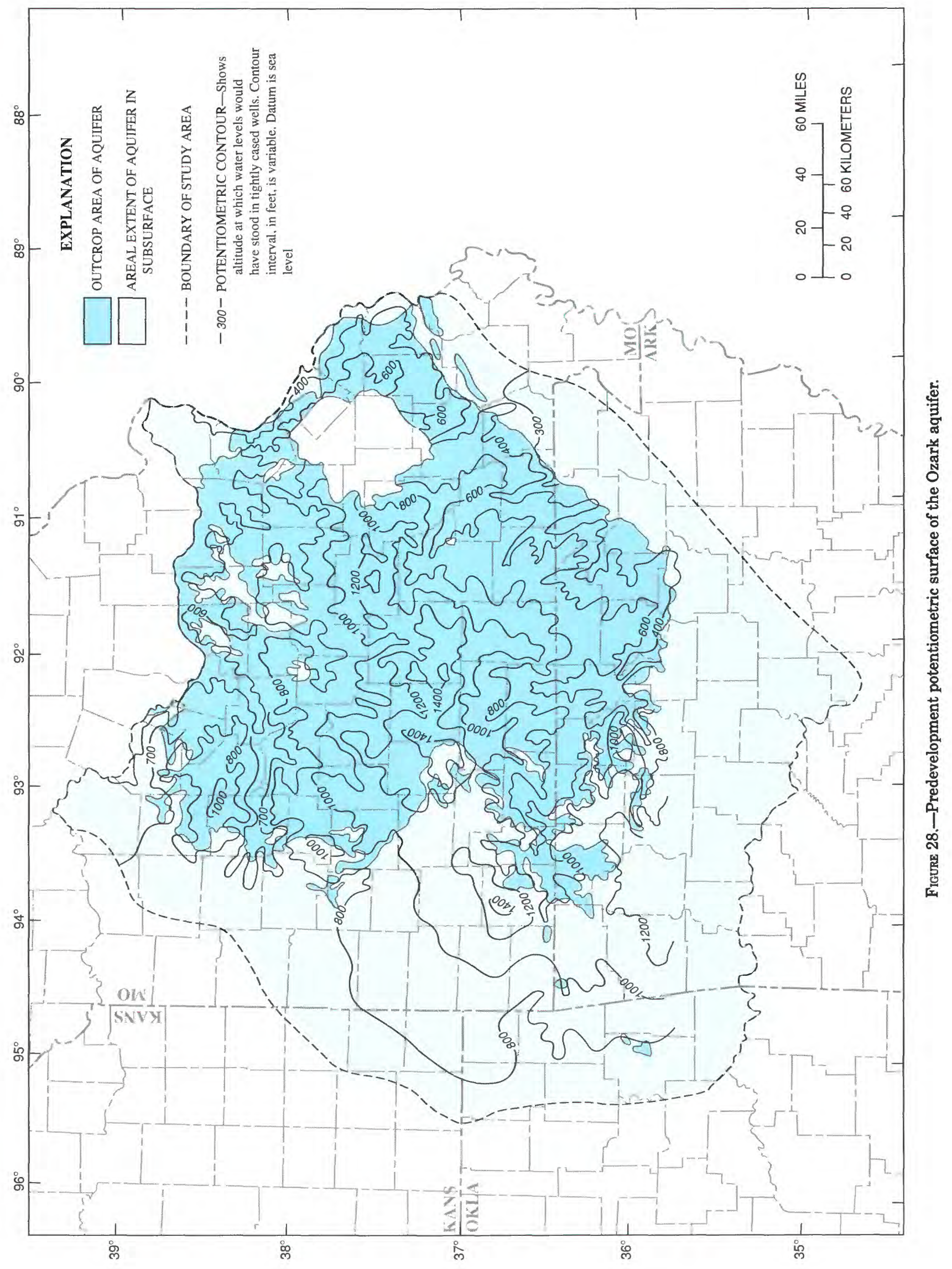


through the aquifer in this area generally is controlled by the larger rivers and regional topographic features, whereas local ground-water movement in the uppermost part of the aquifer also is controlled by the smaller streams and local topographic features. Along the northern and eastern boundaries of the Salem Plateau, the aquifer is incised by the Missouri and Mississippi Rivers. The rivers are major discharge areas for ground water moving north and east from the Salem Plateau.

At the northwestern boundary of the study area, ground water in the Ozark aquifer moves northward beneath the overlying Ozark confining unit and Springfield Plateau aquifer (fig. 12), then discharges upward into the Missouri River valley at the northern edge of Saline, Cooper, and Moniteau Counties (fig. 3). The discharge area also is a mixing zone of freshwater and salinewater. Saline ground water moving eastward toward the study area emerges from beneath the Western Interior Plains confining system, and discharges into the same reach of the Missouri River valley. Along the western edge of the Ozark study area, westward-flowing freshwater in the Ozark aquifer mixes with eastward-flowing saline-water of the Western Interior Plains aquifer system. The mixed water converges toward the South Grand, Marais des Cygnes, and Osage River valleys (fig. 10) and discharges through overlying confining units into the river systems. The discharge area coincides with the area in which the overlying Ozark confining unit is devoid of shale and consists only of limestone (see section "Ozark Confining Unit").

In southwestern Missouri, the aquifer is recharged by leakage through the overlying confining unit, and water in the aquifer flows to the west and northwest into southeastern Kansas. The boundary of the aquifer is not well defined in this area because of the broad freshwater-salinewater mixing zone and the lack of a well-defined discharge area. Although water-level data are sparse, evidence indicates that the more northerly flowing ground water in this area turns northeastward and discharges into the Marais des Cygnes and Osage Rivers, whereas the more westerly flowing ground water turns southward and discharges through overlying deposits into the Neosho River valley in northeastern Oklahoma (fig. 10).

The direction of ground-water flow in northern Arkansas is difficult to accurately determine because data are sparse south of the northernmost tier of counties (Lamonds, 1972). The probable direction of ground-water flow in this area can be inferred from regional topography and geology, the altitude of major rivers, and available water-quality and hydraulic-conductivity data. A regional ground-water divide (fig. 10) parallels the crest of the Boston Mountains in northern Arkansas and separates the region into two distinct ground-water provinces. The divide approximately parallels the northern limit of the Western Interior Plains confining system (fig. 12). North of the divide, the Ozark aquifer is recharged by leakage through the overlying units and by infiltration of precipitation on the outcrop area of the aquifer. The mainly fresh ground water flows to the White and Buffalo Rivers and their tributaries (fig. 10). South of the divide, water in the aquifer flows toward the Arkansas River valley. Because of the large thickness of shale in the Western Interior Plains confining system near the Arkansas River, it is unlikely that any significant quantity of water in the Ozark aquifer discharges through the confining system into the Arkansas River. Instead, the water probably moves eastward to the Mississippi Embayment. The presence of saline springs along the edge of the Mississippi Alluvial Plain near the southeastern border of the study area lends support for this concept of ground-water flow.

Water in the Ozark aquifer that flows southeast beneath the Mississippi Alluvial Plain encounters saline ground water in adjacent aquifers of the Mississippi Embayment (fig. 8). Because the Ozark aquifer dips so steeply into the subsurface beneath the post-Paleozoic overburden (fig. 25), and because hydrologic data on the Ozark aquifer is sparse in this area, it is difficult to determine the distance that freshwater travels beneath the alluvium. However, much, if not most, of the freshwater discharges directly into the overlying alluvial sediments, or percolates upward through Cretaceous sand deposits to discharge into the alluvial sediments, within a few miles of the Ozark Escarpment. Then it discharges into the Black and White Rivers (fig. 10) that flow on the alluvial sediments. This abrupt discharge of ground water occurs within a 5- to 10-mile-wide band along the southeast edge of the Ozark Escarpment where permeable post-Paleozoic deposits are in direct hydraulic contact with the Ozark aquifer. Beyond this band, a confining unit of slightly permeable Cretaceous clay separates the Ozark aquifer from the permeable alluvial material.

\section{Chemical Quality of Ground Water}

The chemical composition of ground water in the Ozark aquifer is a product of dissolution of the dolostone and limestone that form the bulk of the aquifer. The most common water type in the Ozark 
aquifer is calcium bicarbonate or bicarbonate with calcium as the most prevalent cation (fig. 29; table 2; Imes and Davis, 1991). A large area in the northcentral part of the Salem Plateau contains mainly magnesium bicarbonate water. Water that is of a mixed cation bicarbonate type, with either magnesium or calcium dominating, forms a transition zone between many of the areas that contain calcium bicarbonate or magnesium bicarbonate water. There are small areas near the western and southwestern boundaries of the study area in which the water type is sodium bicarbonate or bicarbonate with sodium as the dominant cation. These areas indicate the transition between the predominantly bicarbonate water of the Ozark Plateaus aquifer system and the predominantly sodium chloride water that encircles the plateau to the west, south, and east.

The dissolved-solids content of ground water in the Ozark aquifer reflects the movement of water from the regional ground-water divides toward the surrounding basins. The dissolved-solids content is least along the two major ground-water divides shown in figure 10, generally ranging from less than 200 to about 300 milligrams per liter (fig. 30; Imes and Davis, 1991). Away from the two divides the dissolved-solids content increases to greater than 400 milligrams per liter. In the north-central part of the Salem Plateau, a small area containing dissolvedsolids concentrations greater than $\mathbf{5 0 0}$ milligrams per liter is associated with the recharge of ground water through overlying deposits of Pennsylvanian clay, shale, and sandstone. At the edges of the study area, the dissolved-solids content of ground water in the Ozark aquifer reaches much higher values.

At the extreme northeastern edge of the Ozark study area, the dissolved-solids content of the water increases to the northeast and exceeds 5,000 milligrams per liter where freshwater from the Ozark aquifer mixes with salinewater from other regional aquifers that border the eastern Ozarks outside the study area. Dissolved-solids concentrations increase to as much as 10,000 milligrams per liter in the mixing zone along the western boundary of the aquifer. Figure 30 clearly indicates where salinewater discharges at the northwestern edge of the study area in Saline and Cooper Counties, and, to a lesser degree, where salinewater mixes with freshwater and discharges in Bates and Henry Counties, Missouri (fig. 3).

Southeast of the St. Francois Mountains, the dissolved-solids content increases as freshwater in the Ozark aquifer moves beneath the Mississippi Alluvial Plain and mixes with saline ground water. Few water-quality data are available for the area south of the Boston Mountains; however, dissolved-solids concentrations of water in this area are believed to be quite large (exceeding $1,000 \mathrm{mg} / \mathrm{L}$ ) because water entering the deeply buried Ozark aquifer must pass through thick Pennsylvanian shales, resulting in water having large concentrations of minerals and salts.

The chloride concentration in the Ozark aquifer generally is less than 10 milligrams per liter in the Salem Plateau, where the Ozark aquifer crops out, and in the Springfield Plateau, where the aquifer is overlain by the Ozark confining unit and Springfield Plateau aquifer (figs. 5, 12, 31; Imes and Davis, 1991). Two areas, one in the Salem Plateau in northeastern Arkansas and the other in the Springfield Plateau in northeastern Oklahoma, have chloride concentrations that locally range from 10 to more than 100 milligrams per liter. The chloride concentration does not seem to increase appreciably in the north-central part of the Salem Plateau where Pennsylvanian shale and sandstone cover the Ozark aquifer between the Gasconade and Meramec River valleys (fig. 6). Chloride concentrations increase significantly away from the Ozark Plateaus province. In the extreme northeastern and southeastern part and along the western boundary of the study area, where the Ozark aquifer is in contact with regional salinewater, the chloride concentrations exceed 1,000 milligrams per liter. Analysis of water from one well that penetrates the Ozark aquifer beneath the Mississippi Alluvial Plain in Jackson County, Arkansas (fig. 3), indicated a chloride concentration of 17,000 milligrams per liter.

Sulfate concentrations in the Ozark aquifer generally are less than 10 milligrams per liter in the Salem Plateau (fig. 32; Imes and Davis, 1991). An exception occurs in the north-central part of the plateau where the aquifer is capped by Pennsylvanian shale and sandstone. In this area sulfate concentrations may exceed 140 milligrams per liter locally. The origin of the sulfates probably is pyrite that has concentrated in sinkholes on the paleokarst surface of the aquifer beneath the Pennsylvanian rocks. Sulfate concentrations exceed 100 milligrams per liter in a small area and 300 milligrams per liter in one well in Jefferson County, Missouri (fig. 3). The source of the sulfate ions in this area is not known but may be related to the mining of surficial lead and zinc sulfide deposits. Filled sinkholes also are present in the surface of the Ozark aquifer in this area, but any Pennsylvanian overburden that may have once covered the area has been removed by erosion. Sulfate concentrations generally are less than 20 milligrams per liter in the Springfield Plateau where the Ozark 


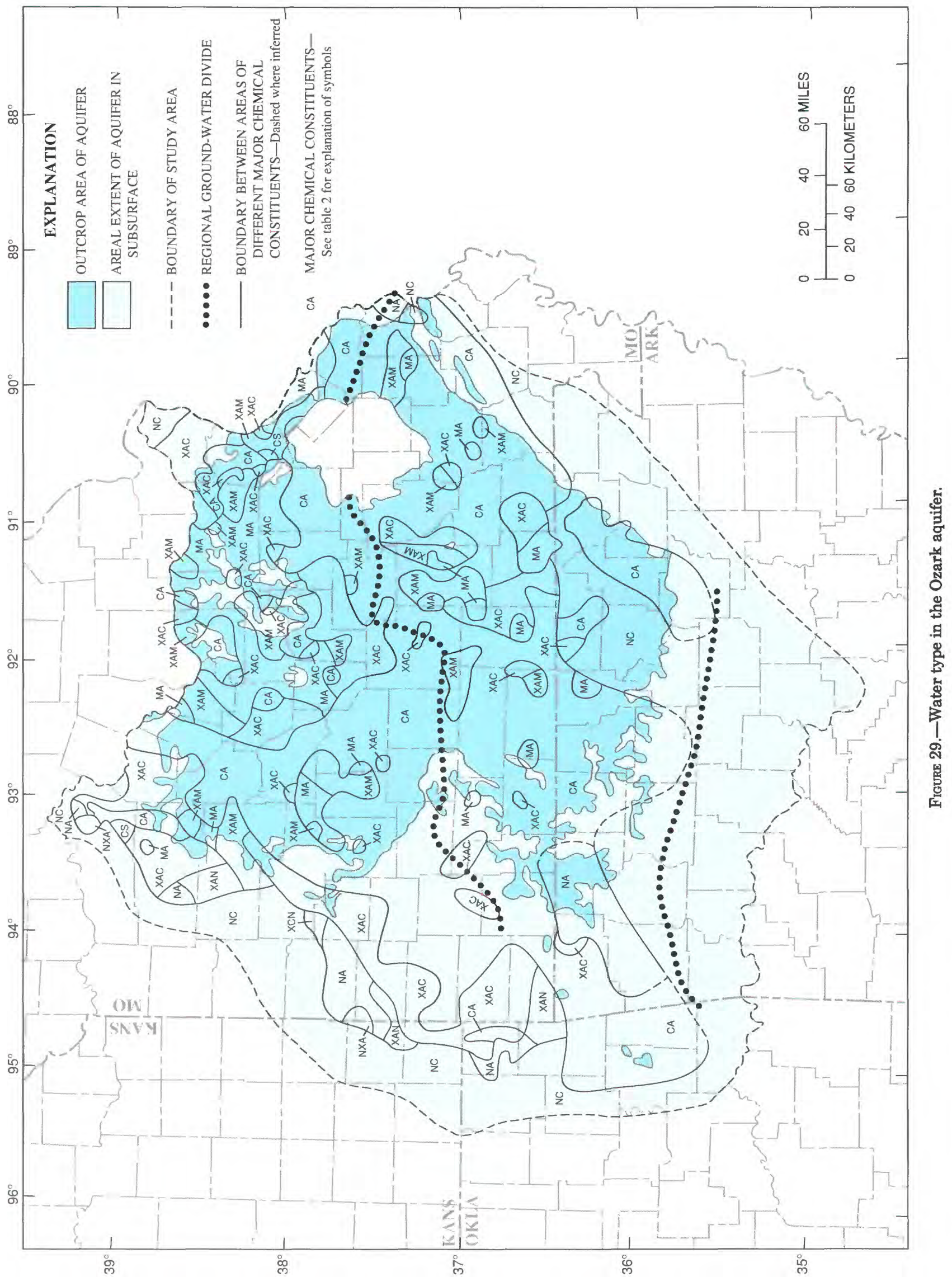




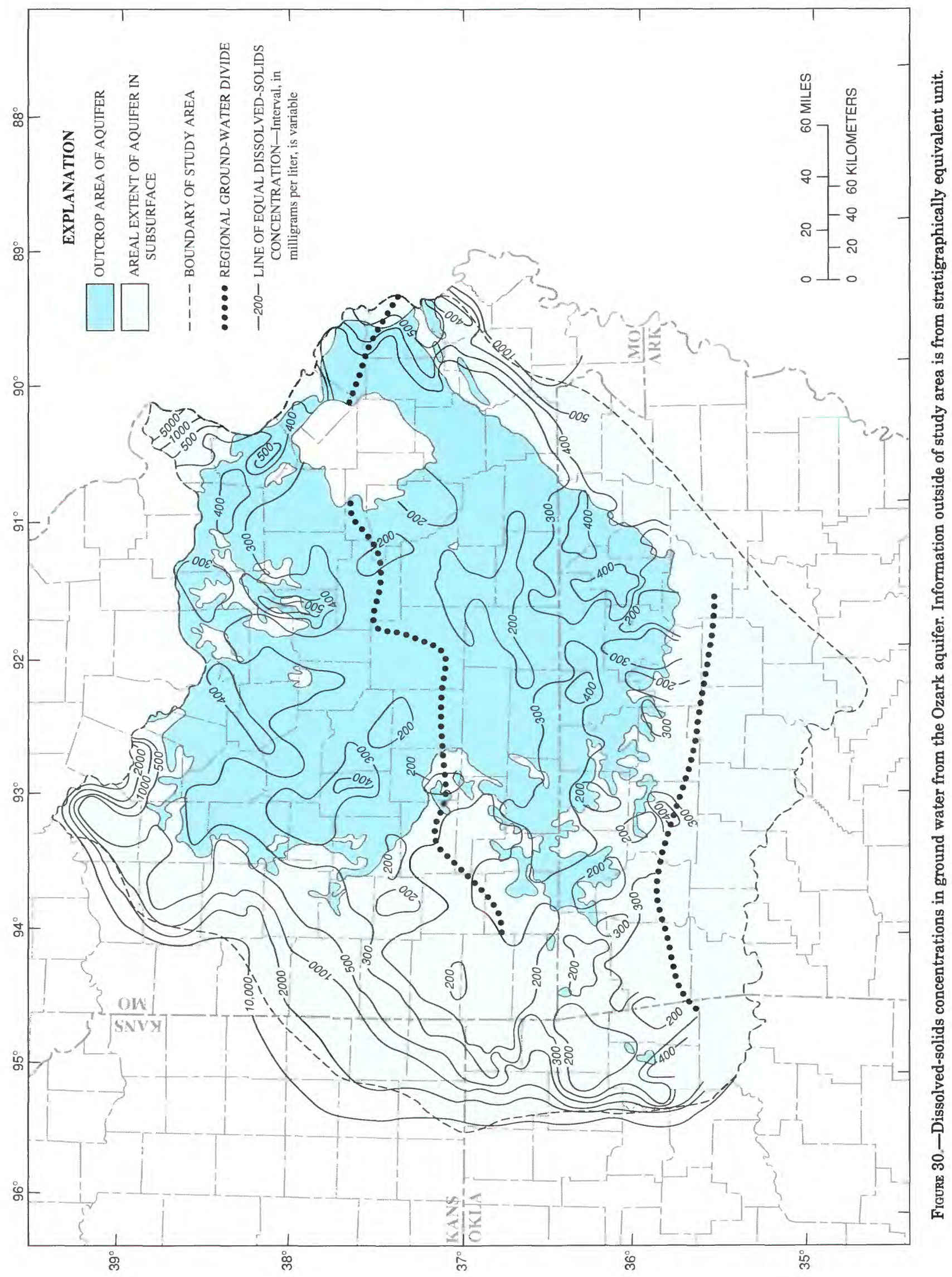




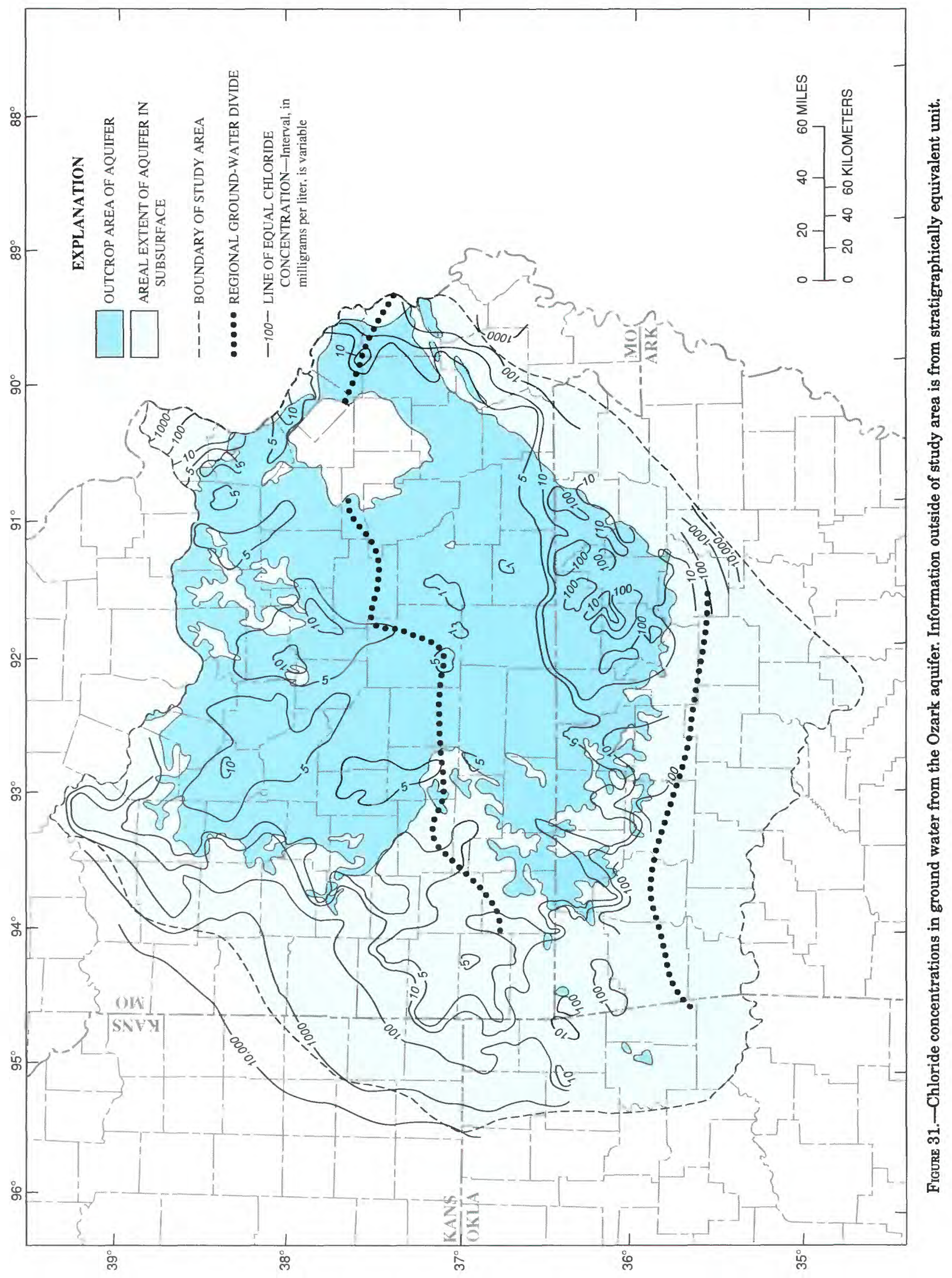




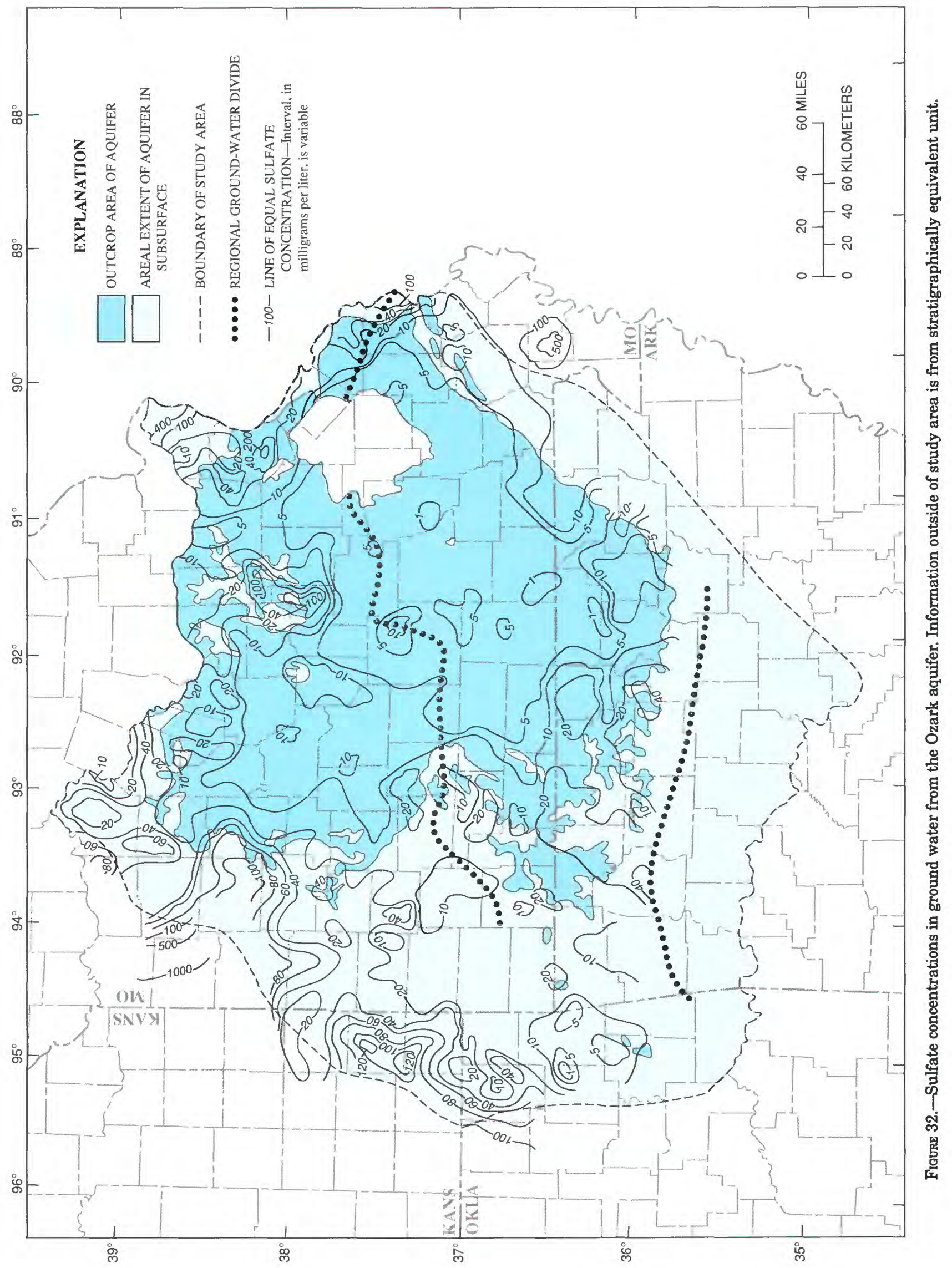


aquifer is confined. Along the northwest edge of the Ozark Plateaus province and beyond its boundaries (fig. 5), the concentrations of sulfate exceed 20 milligrams per liter.

Naturally occurring radioactivity in ground water in excess of U.S. Environmental Protection Agency (USEPA) drinking-water regulations (U.S. Environmental Protection Agency, 1979) has been detected in the Ozark aquifer where freshwater comes into contact with more mineralized water of the transition zone in the tristate region of Kansas, Missouri, and Oklahoma. Radium-226 activity ranged from 0.5 to 11 picoCuries per liter in 58 public water-supply or industrial wells open to the Ozark aquifer (Macfarlane, 1981). Ten of the samples exceeded the USEPA maximum contaminant level of 5 picoCuries per liter. The Missouri Department of Natural Resources (written commun., 1983) listed 31 public water supplies exceeding maximum contaminant levels in 1983. Eighteen of the 31 sites are in or immediately adjacent to the study area. The combined radium-226 and radium-228 activity ranged from 5.1 to 13.9 picoCuries per liter.

\section{OZARK CONFINING UNIT}

The Ozark confining unit restricts flow between the Ozark aquifer and the overlying Springfield Plateau aquifer. The confining unit, composed predominantly of slightly permeable shale and limestone, is the uppermost confining unit in the Ozark Plateaus aquifer system. The confining unit is missing from the Salem Plateau (figs. 5, 12), an area that includes approximately the eastern two-thirds of the study area. In the western and southern one-third of the study area, the unit extends continuously from its outcrop area to the boundary of the Ozark Plateaus aquifer system, except for local areas in northern Arkansas where rocks that form the unit are missing.

The geologic formations in the confining unit are not all present everywhere in the study area. Along the extreme northeastern flank of the Ozarks, the confining unit is composed of a sequence of formations that include the stratigraphic interval from the base of the Upper Ordovician Maquoketa Shale to the top of the Lower Mississippian Chouteau Limestone (table 1). Probably some of the formations in this thick, predominantly limestone sequence are important water-bearing units for the area east of the Ozark Plateaus. Because of the relatively small areal extent of these formations, they have not been subdivided into aquifers and confining units in this study. In the western and southern part of the study area, the confining unit is much thinner and composed mainly of Upper Devonian shales and Lower Mississippian shales and limestones.

Structural Features

The Ozark confining unit crops out in a thin strip that surrounds the outcrop area of the underlying Ozark aquifer (fig. 12). It dips gently to the west in western Missouri and eastern Kansas at about 14 feet per mile. The top of the confining unit is at about sea level at the boundary of the Ozark Plateaus aquifer system in southeastern Kansas (fig. 33; Imes, 1990e). In northeastern Oklahoma, atop a southwestern extension of the Ozark uplift, the altitude of the top of the unit varies from about 700 to 1,000 feet. The altitude of the unit decreases abruptly along the western and southern flanks of the extension. In northern Arkansas the altitude of the top of the confining unit decreases from about 1,000 feet in Carroll County (fig. 3) to lower than 5,000 feet below sea level beneath the Arkansas Valley (fig. 5). The dip increases from about 30 feet per mile in the northern part to about 250 feet per mile in the southern part of northern Arkansas.

THICKNESS

Well logs indicate that the thickness of the Ozark confining unit generally ranges from near 0 to more than 1,000 feet in the Ozark Plateaus province. The unit is thickest in one small area at the extreme eastern edge of Perry County, Missouri (figs. 3, 34; Imes, 1990e). In northeastern St. Louis County, Missouri, the unit is more than 200 feet thick. However, the confining unit generally is less than 100 feet thick and is, therefore, relatively thin in comparison to the other geohydrologic units. The confining unit is less than 10 feet thick along a narrow belt from Christian County, Missouri, to Montgomery County, Kansas. This belt is nearly coincident with the Bourbon arch, which extends from southwestern Missouri into southeastern Kansas and separates the Forest City and Cherokee basins (fig. 8).

North and south of this belt, the confining unit thickens to about 80 feet. In northern Arkansas, the thickness of the confining unit generally increases southward from the Salem Plateau to about 50 feet in the Arkansas Valley. Rocks that form the confining unit are missing in the subsurface from small areas in Kansas and Oklahoma (not shown in fig. 34) and from larger areas in northern Arkansas. The unit 


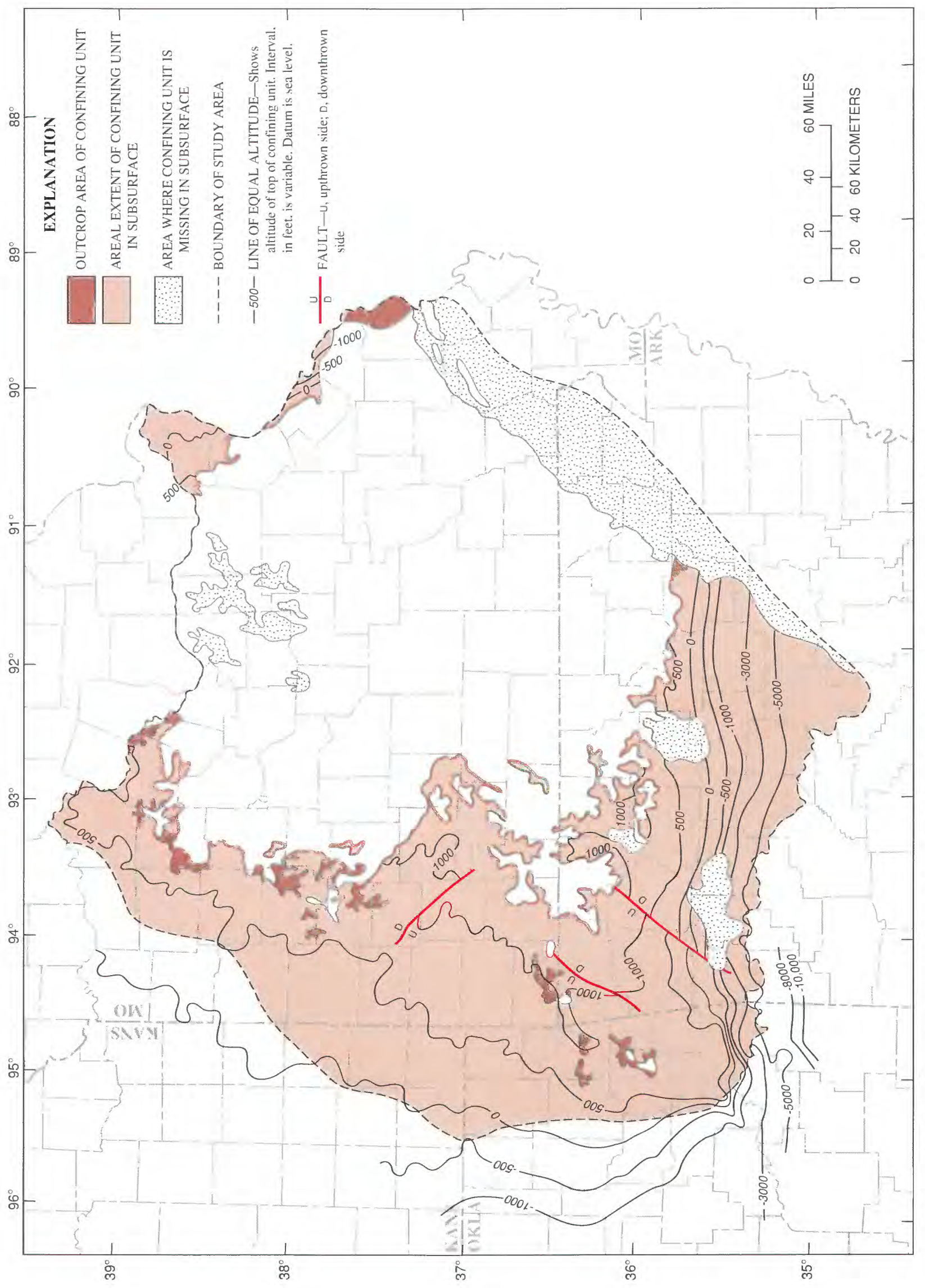

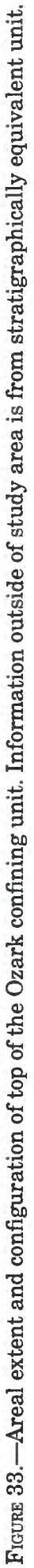




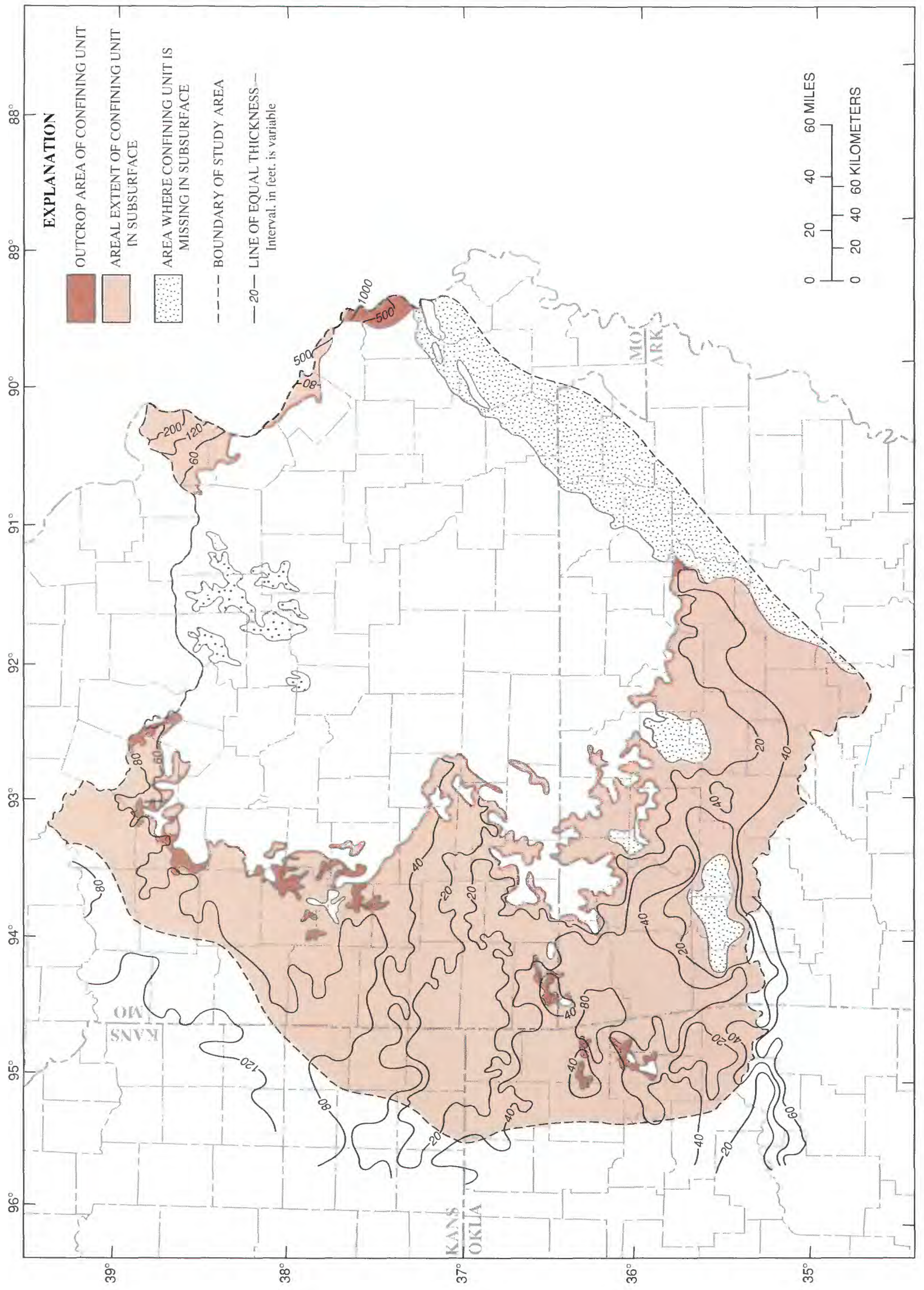

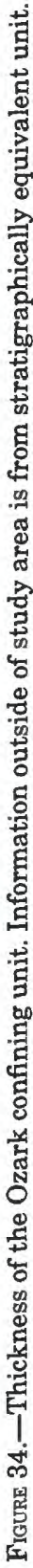


also is absent in the subsurface from a large area in the northern part of the Ozark Plateaus province (Gasconade County, Missouri (fig. 3), and vicinity) where Pennsylvanian rocks are in direct contact with the underlying Ozark aquifer. In addition, it is missing from a large area southeast of the Ozark Plateaus province where the Ozark Plateaus aquifer system is blanketed by unconsolidated sediments of the Mississippi Alluvial Plain.

Lithology and Geohydrologic Properties

The leakance of the Ozark confining unit varies because of local lithologic and structural differences. The effectiveness of the hydraulic connection between the overlying Springfield Plateau aquifer and the underlying Ozark aquifer, therefore, can vary considerably from one location to another.

Along the northeast boundary of the study area, the Ozark confining unit is lithologically more complex than elsewhere, primarily because it is composed of more formations. Limestone predominates the rock strata, but shale is well represented, and sandstone also is present in small quantities. The thickness of the major shale formations-the $\mathrm{Ma}$ quoketa Shale, Orchard Creek Shale, Chattanooga Shale, and Hannibal Shale (table 1)-may total as much as $\mathbf{1 0 0}$ feet. Many of the limestone rocks contain a significant fraction of argillaceous material in the form of shale partings that are distributed in the carbonate matrix. The small quantities of sandstone are confined mostly to scattered occurrences in the Grand Tower Limestone and St. Laurent Limestone and to the thin Bushberg Sandstone. In the northwest part of the study area, the lithology of this confining unit changes locally depending on the presence or absence of one or more of three Lower Mississippian formations: the Compton Limestone, the Sedalia Limestone, and the Northview Shale. In northeastern Oklahoma and northern Arkansas, the confining unit is represented by the Chattanooga Shale, a predominantly shale unit containing small and areally limited quantities of sandstone. The Chattanooga Shale extends throughout the southwestern and southern parts of the study area and is the most important formation in the confining unit.

The shale content and equivalent shale thickness of the Ozark confining unit provide one indication of its effectiveness as a confining unit. Shale in the Ozark confining unit exists as distinct beds, shale partings, and as distributed shale in a limestone and dolostone matrix. Shale beds and partings can form effective barriers to the vertical leakage of ground water across the unit. They also can allow the free passage of water if they contain a significant density of fissures or fractures. Distributed shale can block the passage of ground water through the pore spaces in a carbonate rock matrix and reduce the vertical hydraulic conductivity of the rock.

The shale content of the Ozark confining unit as a percentage of the total thickness of the unit ranges from 0 to 100 percent (fig. 35; Imes, 1990e). Generally, shale constitutes a smaller percentage of rock type in the north and becomes more predominant in the south. The Chattanooga Shale is absent in the north, and the Northview Shale is the primary source of shale there. Several isolated areas along the north and northwest edge of the study area are devoid of shale because of the discontinuous areal distribution of the Northview Shale. In southwestern Missouri and southeastern Kansas the percentage of shale in the confining unit varies abruptly within short distances-from less than 20 to 100 percent. In the southwestern and southern part of the study area, the confining unit is represented almost exclusively by the Chattanooga Shale. In much of this area, shale constitutes 100 percent of the confining unit.

The shale content map cannot be used alone to evaluate probable spatial variations in the vertical hydraulic conductivity of the confining unit because the net shale content of a thin unit having a large percentage of shale can be considerably less than the net shale content of a thick unit having a small percentage of shale. The net thickness of shale in the confining unit can be calculated using the shale content and thickness maps of the unit. The net shale thickness map (fig. 36) shows the total thickness of shale as if it were consolidated into one distinct bed instead of being distributed throughout the unit.

In the extreme northeastern part of the study area, the net shale thickness increases to the northeast to more than 120 feet. The net shale thickness in this area reflects both an increasing thickness and an increasing shale content. There is no shale in the confining unit in several areas along the northwest edge of the study area. The lack of shale in these isolated locations does not necessarily indicate the Ozark confining unit is permeable. The limestones that constitute the confining unit are thick in this area (approximately 50 to $100 \mathrm{ft}$ ) and have not developed a significant secondary permeability. Thus, the limestones can form an effective barrier to the vertical leakage of ground water if their primary permeability is sufficiently small and their thickness sufficiently large. However, there are data that indicate the vertical hydraulic conductivity of the confining unit in this area is greater than the conductivity of the 


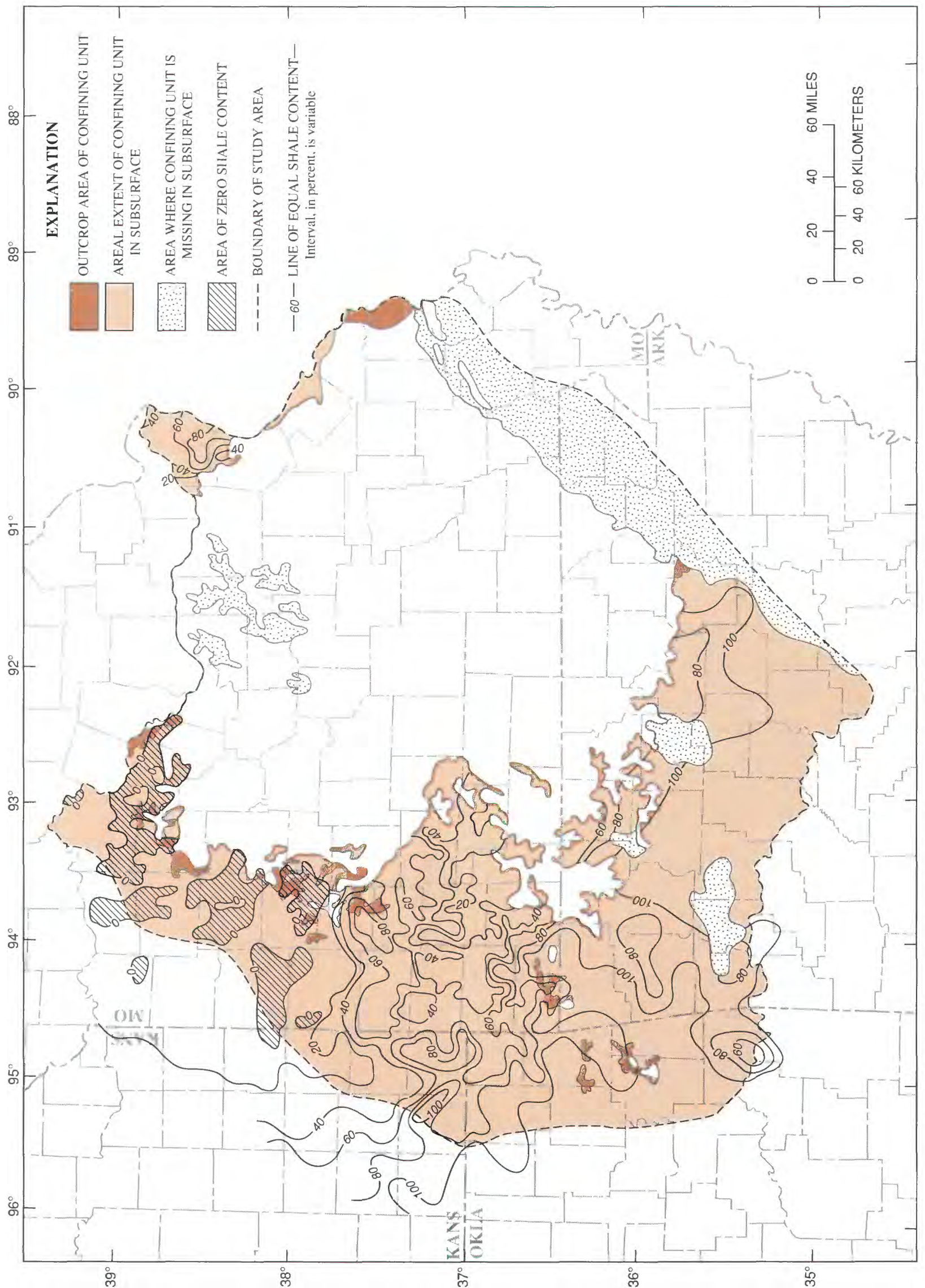




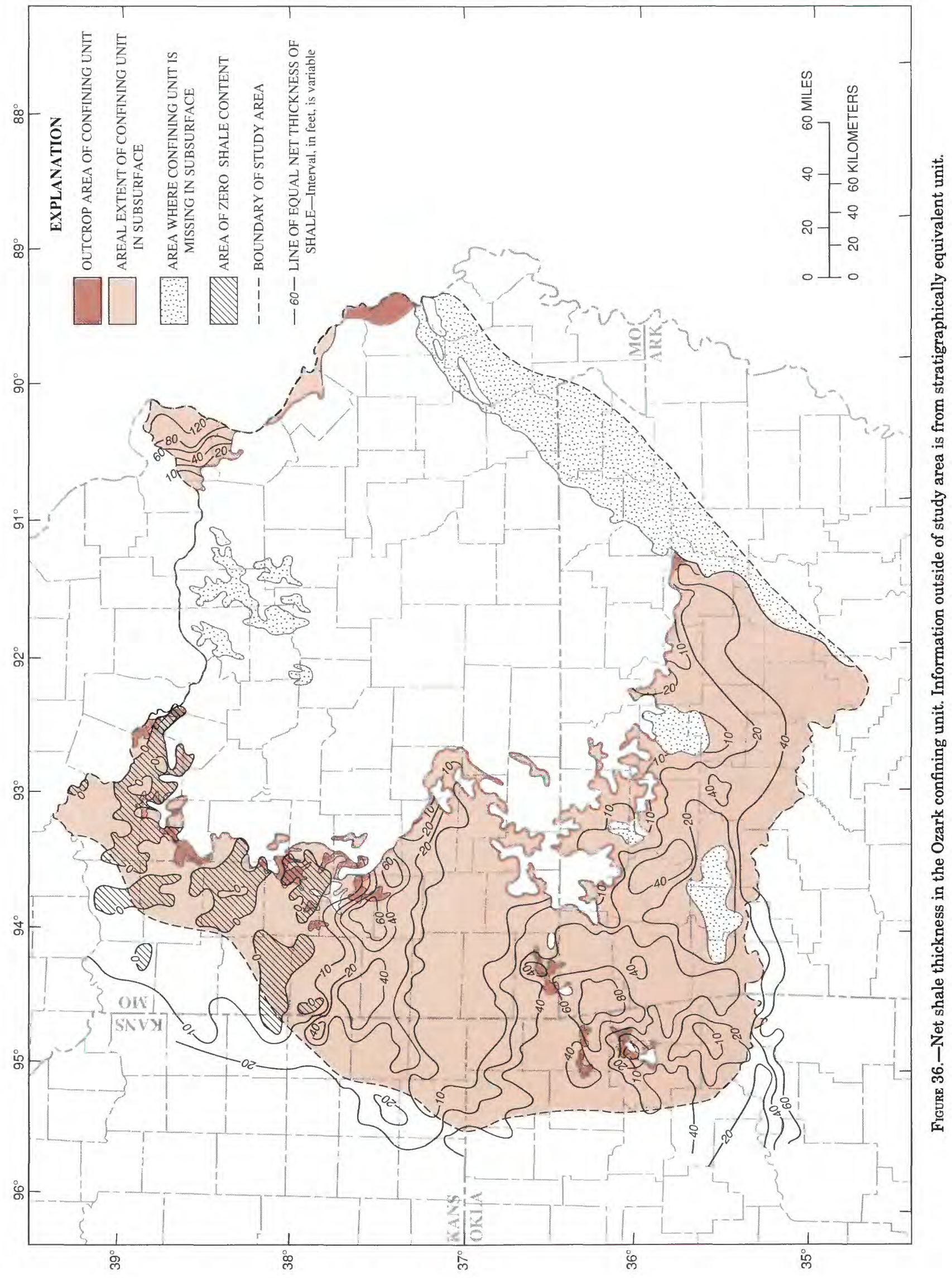


unit farther south. The difference in head between the underlying Ozark aquifer and the overlying Springfield Plateau aquifer ranges from 10 to 50 feet in the areas where shale is missing. In southwestern Missouri and southeastern Kansas, where the net shale thickness of the thinner confining unit ranges from less than 10 to more than 40 feet, the head difference usually is more than 50 feet. In northeastern Oklahoma and northern Arkansas the net shale thickness of the unit generally increases to the south and varies from less than 10 feet to more than 80 feet. The areas of greater net shale are located along the southwest extension of the Ozark uplift into northeastern Oklahoma.

\section{SPRINGFIELD PLATEAU AQUIFER}

The Springfield Plateau aquifer is a sequence of water-bearing Mississippian limestone and chert that forms the uppermost geohydrologic unit in the Ozark Plateaus aquifer system. Geologic formations that are stratigraphically equivalent, but hydrologically unrelated, to those that constitute the Springfield Plateau aquifer are present in the extreme northeastern part of the study area. These formations are not considered to be part of the Springfield Plateau aquifer. In the western part of the study area, the aquifer is composed of the limestone formations between the base of the Pierson Formation and the top of the St. Louis Limestone (table 1). In northeastern Oklahoma the Springfield Plateau aquifer is represented by three geologic formations: the Boone Formation, the Keokuk Limestone, and the Moorefield Formation. Because the permeability of the Moorefield Formation is smaller in northern Arkansas, where the shale content of the formation is larger, this formation is not included as part of the Springfield Plateau aquifer in Arkansas, and the aquifer is represented there only by the Boone Formation.

\section{Structural Features}

The Springfield Plateau aquifer crops out on the Springfield Plateau, which constitutes about onethird of the Ozark Plateaus province (figs. 5, 12). In the northwestern part of the study area, the aquifer dips to the northwest at about 11 feet per mile. West of the Springfield Plateau, the aquifer is buried beneath nearly impermeable rocks of the Western Interior Plains confining system to a maximum depth of about 250 feet in the more northerly areas and about 500 feet in southeastern Kansas (fig. 37). The western boundary of the aquifer in northeastern Oklaho- ma is approximately coincident with the western edge of the outcrop area of the aquifer. However, near the southern reach of that boundary the aquifer dips abruptly into the subsurface and is overlain by as much as 4,000 feet of the Western Interior Plains confining system. The aquifer is missing in the subsurface beneath the Arkansas River along the southern boundary of the aquifer in Oklahoma. In northern Arkansas, where the southward dip of the aquifer can exceed 200 feet per mile, the depth of burial by the confining system exceeds 5,000 feet.

The altitude of the top of the aquifer in the northwestern part of the study area ranges from about 800 feet above sea level near the western boundary of the Salem Plateau to about 500 feet or less at the western edge of the aquifer (fig. 38; Imes, 1990f). The altitude of the aquifer top in the outcrop area generally is greater than 1,000 feet and locally can exceed 1,500 feet. Near its southern boundary, the top of the aquifer can be lower than 5,000 feet below sea level. The Springfield Plateau aquifer has been eroded from the part of the study area that extends southeast into the Mississippi Alluvial Plain.

\section{THICKNESS}

Northwest of the Salem Plateau the thickness of the Springfield Plateau aquifer is less than 200 feet (fig. 39; Imes, 1990f). The thickness of the aquifer generally increases to the northwest from near zero along the boundary of the Salem. Plateau. Rocks that constitute the aquifer are missing in the subsurface from two relatively small areas in and near Henry County, Missouri (fig. 3). The aquifer generally is thicker in southwestern Missouri, southeastern Kansas, and northeastern Oklahoma, ranging from 200 to 400 feet thick throughout most of the area. In northeastern Oklahoma, the aquifer is thinner near the small areas where the aquifer is missing and older rocks are exposed. The thickness of the aquifer can exceed 300 feet in areas between outcrops of the older rocks. The thickness of the aquifer in northern Arkansas generally is less than 400 feet. Unlike the thickness of geohydrologic units above and below the Springfield Plateau aquifer, the thickness of the aquifer does not greatly increase in the southern part of the study area.

Lithology and Geohydrologic Properties

The Springfield Plateau aquifer primarily consists of coarsely crystalline limestones of Mississippian age that commonly contain a large percentage of 


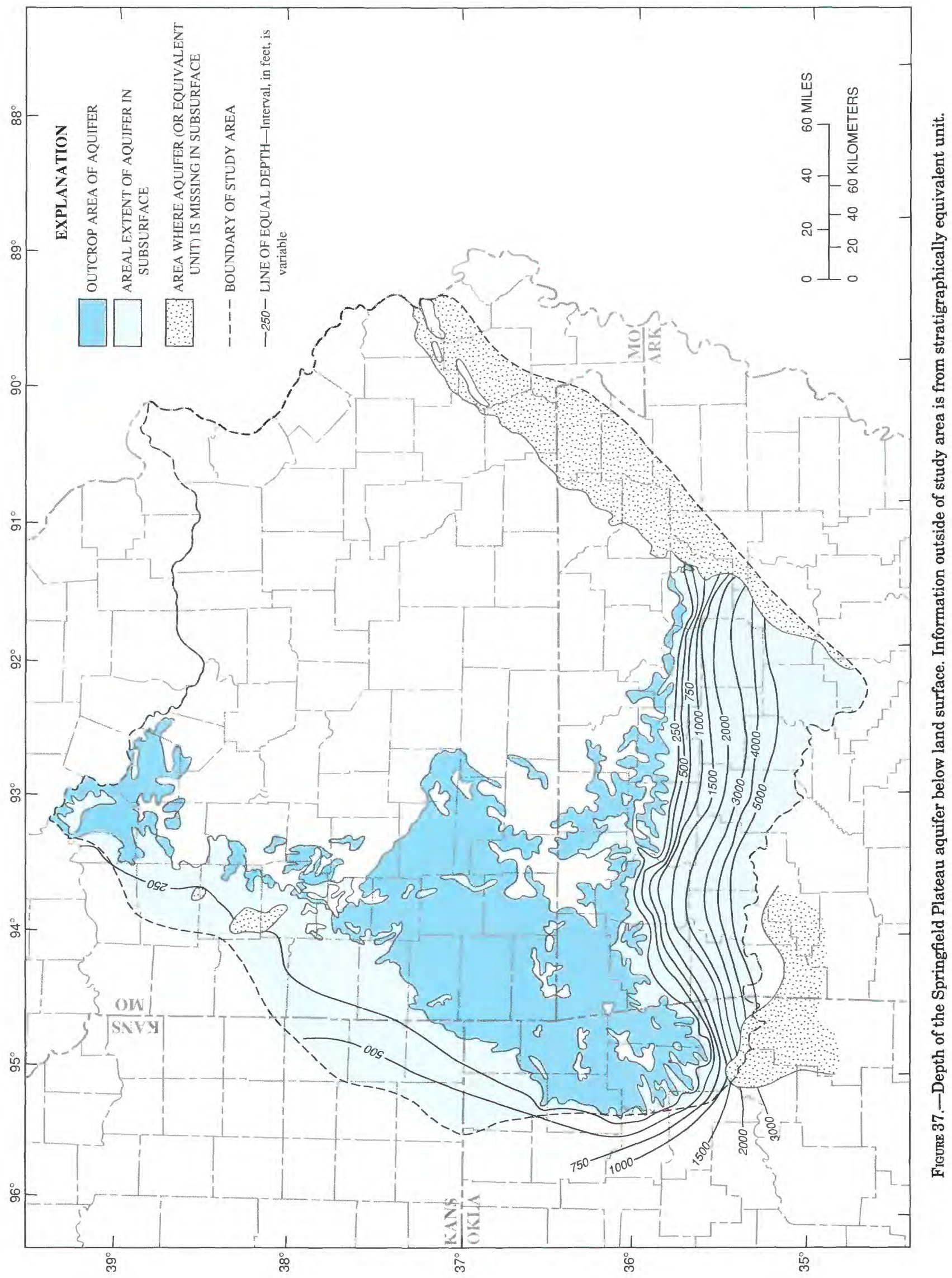




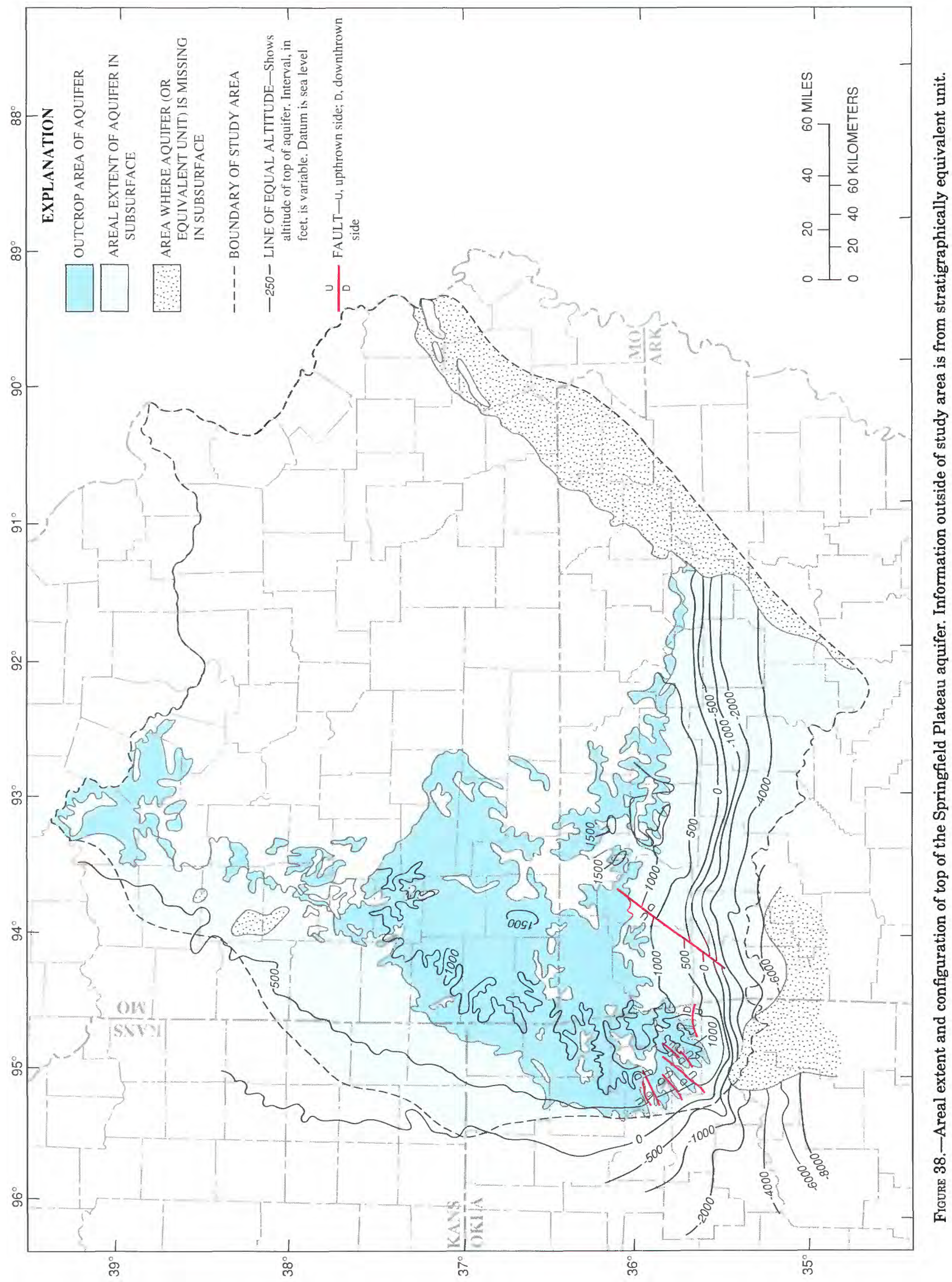




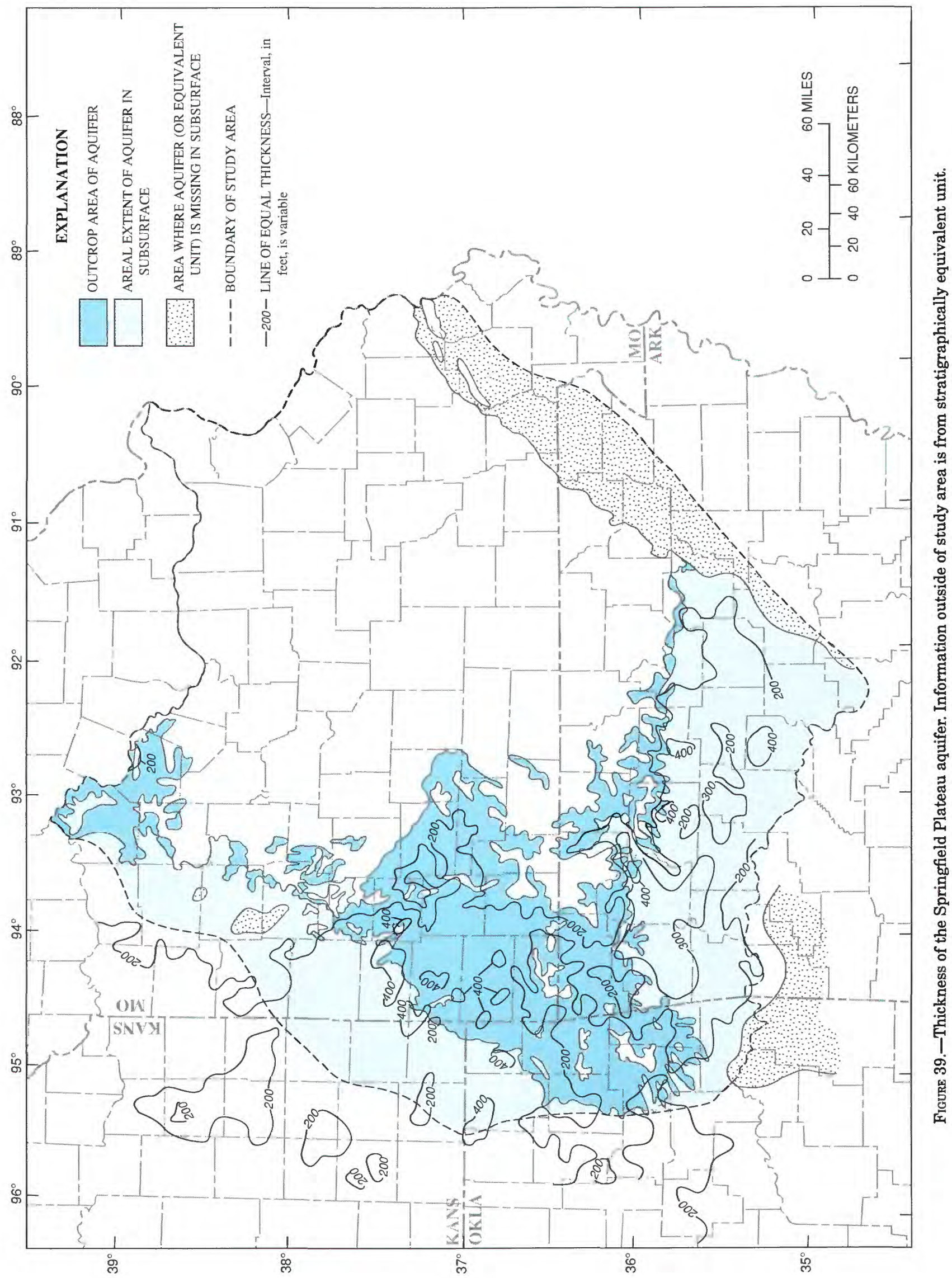


chert. In western Missouri and southeastern Kansas the more important geologic formations in the aquifer are the thicker and more permeable Burlington and Keokuk Limestones (table 1). These two formations have similar lithologies: medium-crystalline to coarsely crystalline bedded limestone containing abundant quantities of gray chert, mainly in the form of nodules. The upper 100 to 200 feet of the extremely soluble limestone is a well-developed karst terrane with an extensive network of solution channels. Most of the solution channels are oriented along joints and bedding planes. In many areas these solution channels have enlarged to the point where the rock matrix has collapsed, producing caves and other large karst features and significantly increasing the rock permeability. The underlying Fern Glen Limestone and Pierson Formation are not as thick as the Burlington and Keokuk Limestones and do not contain an extensive network of solution channels (Frick, 1980); however, these formations are permeable. Formations that overlie the Burlington and Keokuk Limestones are not thick or areally extensive in this area, and where they are present, the lack of solution-channel development and presence of interbedded shale usually makes them much less permeable than the underlying rocks of the aquifer.

In northeastern Oklahoma, the Burlington Limestone is not present, and the Springfield Plateau aquifer is composed of the Boone Formation, the Keokuk Limestone, and the Moorefield Formation (table 1). The Boone Formation and Keokuk Limestone are lithologically and hydrologically similar to the Burlington and Keokuk Limestones of southwestern Missouri, but they are not as permeable because the karst terrane is not as well developed. The upper part of the Boone Formation generally contains significant quantities of chert. Generally, the chert is fractured, and the formation is permeable. Chert is much less common in the St. Joe Limestone Member, the basal member of the Boone Formation. The Reeds Spring Member of the Boone Formation and the overlying Keokuk Limestone have similar lithologies in this area. Both formations consist of dense, fine-grained limestone and massive gray chert. The chert content of the Keokuk Limestone is greater than that of the Reed Springs Member. Chert in the Keokuk Limestone of northeastern Oklahoma is fractured, and the formation is permeable. The Moorefield Formation, which grades from argillaceous limestone to siltstone and shale, probably is not very permeable.

In northern Arkansas, the aquifer is represented by the Boone Formation. The chert content of the Boone Formation increases from west to east, but the formation remains permeable because of dissolution of limestone along fractures and bedding planes. The Boone Formation is the source of many springs where the unit crops out in northern Arkansas. The Moorefield Formation in northern Arkansas contains a significant fraction of shale and for this reason is assigned to the Western Interior Plains confining system in the southern part of the study area.

\section{Recharge, Ground-Water Flow, and Discharge}

Where the Springfield Plateau aquifer crops out and is unconfined, the potentiometric surface generally reflects the local topographic relief. The altitude of the potentiometric surface is highest along a line from Barry County, Missouri, to Washington County, Arkansas (figs. 3, 40; Imes, 1990f), where it exceeds 1,400 feet. From the areas with the highest waterlevel altitude, ground water discharges downward through the underlying Ozark confining unit into the Ozark aquifer and then moves east to discharge into the White River, or it moves laterally in the Springfield Plateau aquifer to the west and discharges into the Spring and Neosho Rivers. Even where the Springfield Plateau aquifer is confined beneath several hundred feet of shale, sandstone, and limestone along the western perimeter of the study area (fig. 37 ), the potentiometric surface of the aquifer is still affected by local topographic relief.

In west-central Missouri, ground-water flow in the Springfield Plateau aquifer is controlled by topographic relief and by interaction with saline ground water in stratigraphically equivalent beds that constitute the Western Interior Plains aquifer system. The transition zone between freshwater and salinewater is a few miles west of the eastern limit of the overlying Western Interior Plains confining system (fig. 12) and coincides with the transition zone bounding the underlying Ozark aquifer. The effect of topography on the potentiometric surface of the shallower Springfield Plateau aquifer is more apparent in the transition zone than the corresponding effect on the deeper Ozark aquifer. Most freshwater that enters the Springfield Plateau aquifer in the upland areas between the eastward-flowing rivers flows perpendicular to the river valleys and discharges into the Blackwater, Marais des Cygnes, and South Grand River valleys (fig. 40). Eastward-moving saline ground water flows parallel to and beneath these major river valleys and, subsequently, mixes with the freshwater from the upland areas and discharges into the rivers. This is possible because the lower potentiometric heads in the river valleys do not impede 


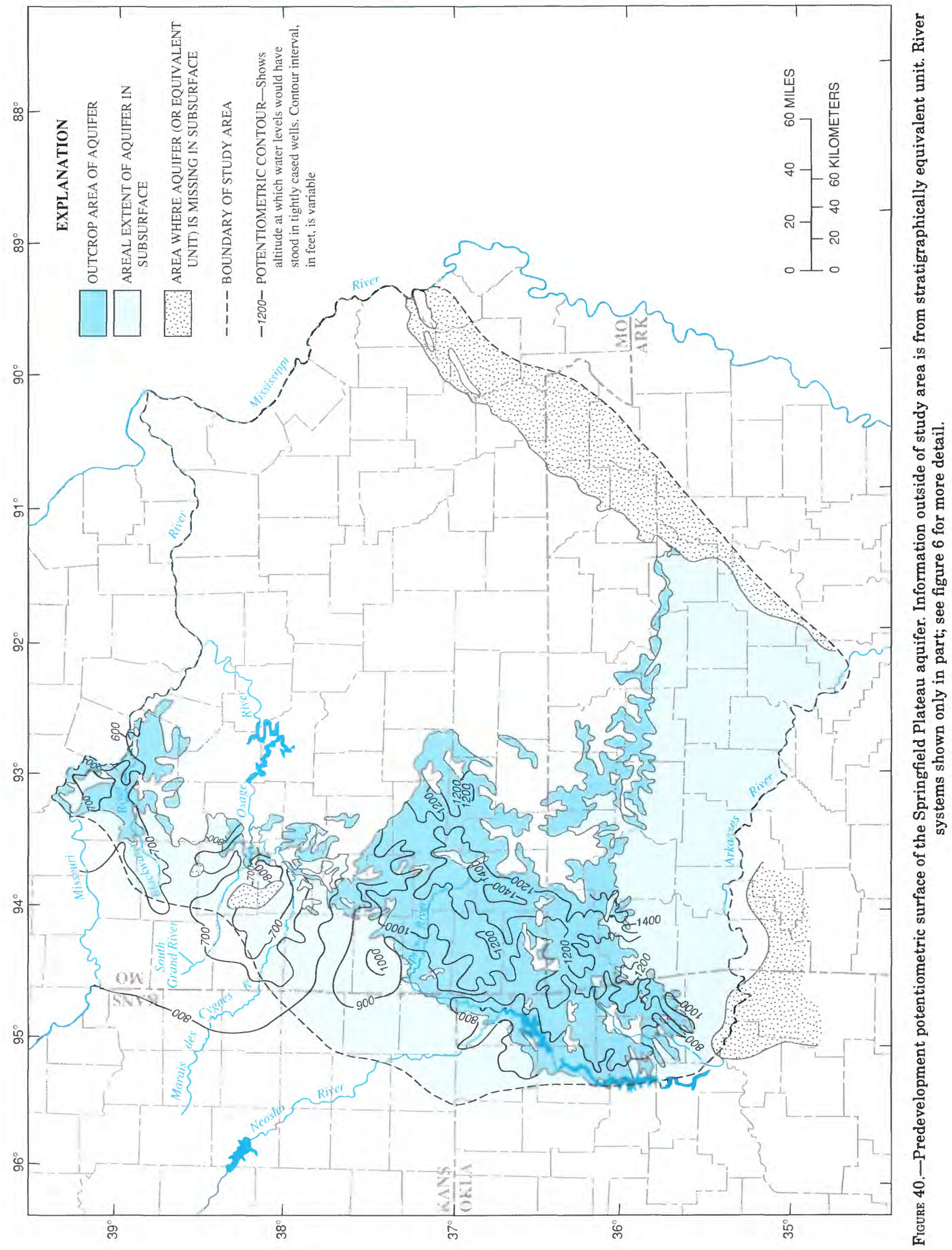


the eastward movement of the saline ground water, whereas the heads in the upland areas are sufficiently high to prevent the saline ground water from flowing beneath the uplands.

Water-level data for the Springfield Plateau aquifer in northern Arkansas are sparse. The few head measurements available in Searcy County, Arkansas (fig. 3), where the aquifer crops out and is a source of domestic water supply, are insufficient for contouring the water table. The general direction of ground-water flow in the Springfield Plateau aquifer in northern Arkansas is assumed to be similar to that of the Ozark aquifer because (1) the outcrop of the Springfield Plateau aquifer in Arkansas occupies only a narrow band that parallels the outcrop area of the Ozark aquifer, and (2) the Springfield Plateau aquifer abruptly dips beneath thick deposits of relatively impermeable shale that constitute the overlying Western Interior Plains confining system. Because of the high altitude of the water table near the Boston Mountains and the low altitude of the Arkansas River valley, it is hypothesized that ground water in the southern part of the study area generally moves south toward the Arkansas River valley.

\section{Chemical Quality of Ground Water}

Water type in the part of the Springfield Plateau aquifer that crops out in southwestern Missouri and northeastern Oklahoma is calcium bicarbonate (fig. 41; table 2; Imes and Davis, 1990b). The water type in this area is controlled by the dominance of limestone in the aquifer. West of the outcrop area in southeastern Kansas is a small area containing calcium sulfate water. Northeast of this area, where the aquifer is blanketed by up to a few hundred feet of shale and silty sandstone, sulfate is the dominant anion, but sodium replaces calcium as the dominant cation. Sodium chloride water is present in the aquifer along most of the northwestern boundary of the study area where the aquifer is confined by the Western Interior Plains confining system. Near Saline County, Missouri (fig. 3), the water type is predominantly sodium chloride, but calcium bicarbonate water is present in areas of local recharge.

At the northwestern edge of the Salem Plateau in and near Saline County, Missouri, the dissolvedsolids concentration of water in the Springfield Plateau aquifer ranges from about 500 milligrams per liter to about 10,000 milligrams per liter (fig. 42; Imes and Davis, 1990b). The high concentrations of dissolved solids occur where eastward-flowing salinewater mixes with freshwater in the aquifer in northern Saline County parallel to the Missouri River, in southern Saline County parallel to the Blackwater River, and in east-central Saline County parallel to Salt Fork (not shown). The dissolvedsolids concentration is less than 1,000 milligrams per liter where the aquifer is recharged by freshwater percolating through a thin layer of Pennsylvanian rocks in central Saline County. Large meanders in the 500- and 1,000-milligrams-per-liter concentration lines in and near Henry County, Missouri, indicate where salinewater mixes with freshwater in the aquifer and discharges into the South Grand, Marais des Cygnes, and Osage Rivers. Dissolved-solids concentrations in areas where the aquifer crops out in southwestern Missouri, northeastern Oklahoma, and northern Arkansas can exceed 400 milligrams per liter locally, but more typically they are within the range of 100 to 300 milligrams per liter. At the western boundary of the aquifer in northeastern Oklahoma the concentration of dissolved solids increases abruptly.

In the outcrop area, chloride concentrations in ground water from the aquifer generally are less than 10 milligrams per liter in southwestern Missouri and northeastern Oklahoma, but can exceed 100 milligrams per liter locally in northwestern Arkansas (fig. 43; Imes and Davis, 1990b). Where the aquifer lies beneath the Western Interior Plains confining system in southeastern Kansas and northeastern Oklahoma, the chloride concentration increases to greater than 100 milligrams per liter. In and near Saline County, Missouri (fig. 3), chloride concentrations in ground water are larger beneath the Missouri and Blackwater Rivers than beneath the highlands between the rivers (fig. 6). The increase in chloride concentrations is due to mixing of salinewater with freshwater in these areas.

Sulfate concentrations in water from the aquifer generally are less than 10 milligrams per liter in the outcrop area (fig. 44; Imes and Davis, 1990b). Concentrations greater than 50 milligrams per liter occur near Saline County, Missouri, and along part of the western boundary of the aquifer. The areas of greatest concentrations are located in the tristate (Kansas-Oklahoma-Missouri) lead-zinc mining district. Presumably, the larger concentrations of sulfate in this area are the product of the oxidation of sulfide minerals that took place when the mine shafts were dewatered. Later refilling of the mine shafts with ground water allowed dissolution of the sulfate ions, resulting in local larger concentrations of sulfate in the water (Spruill, 1984). 


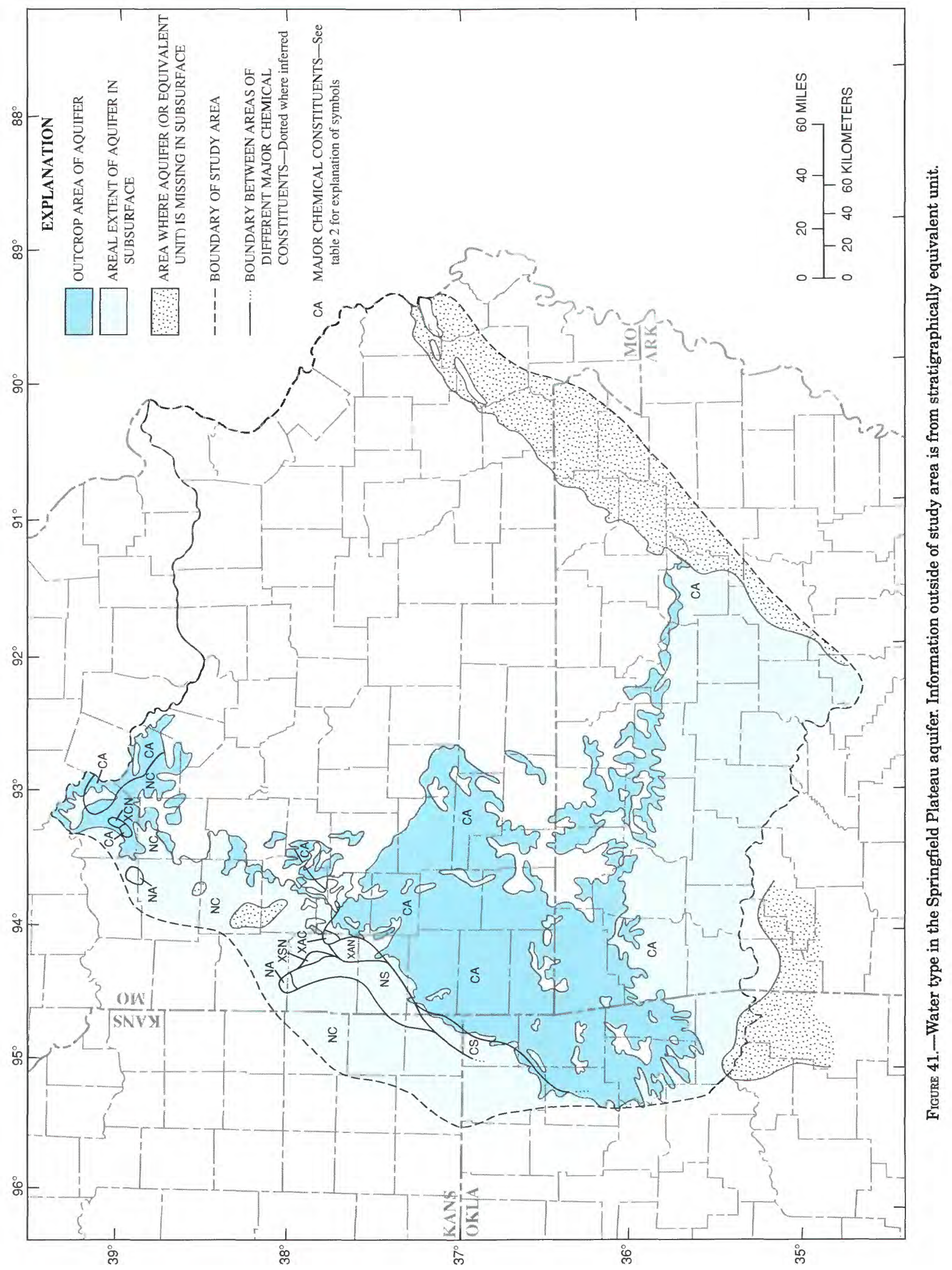




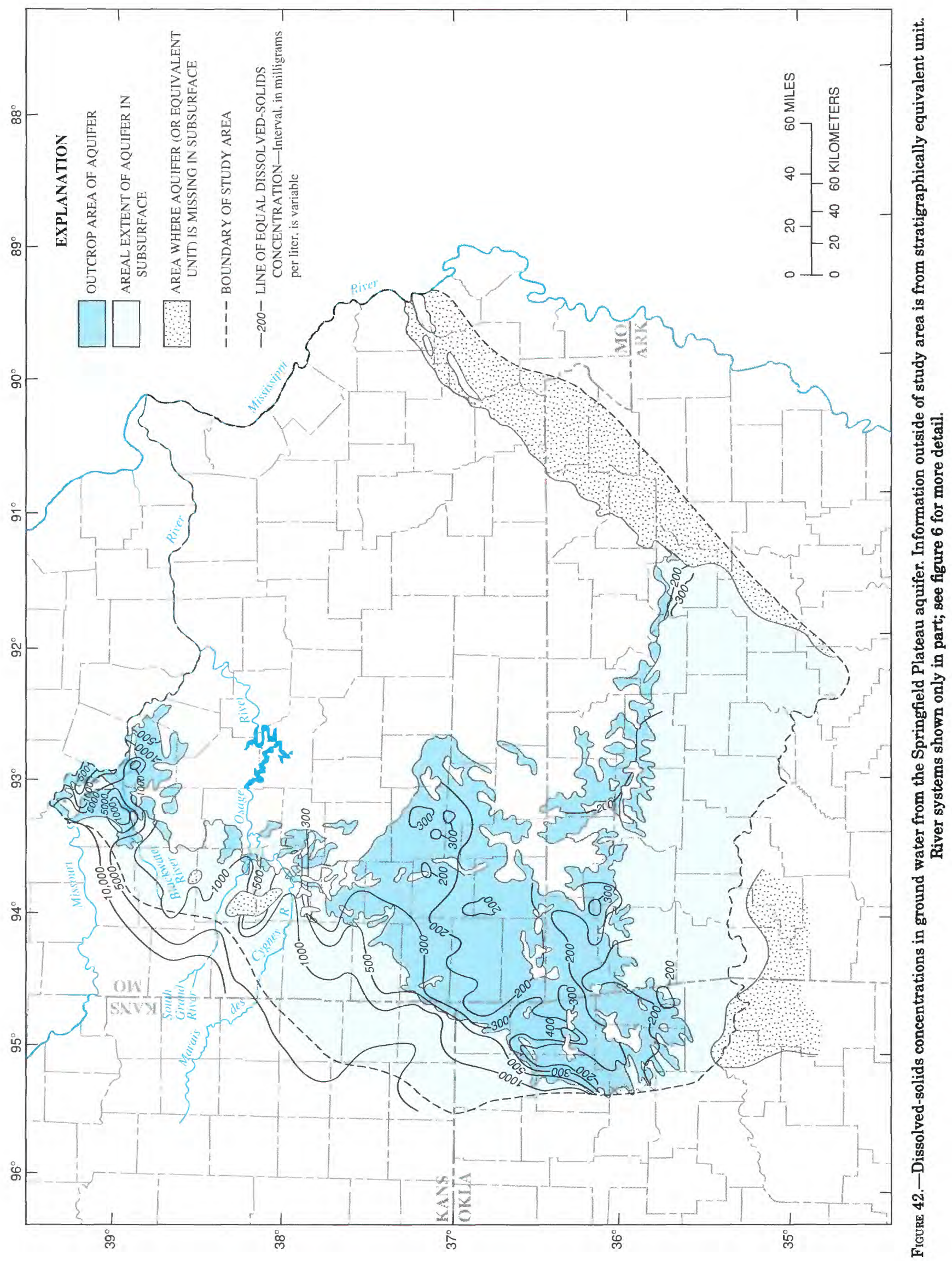




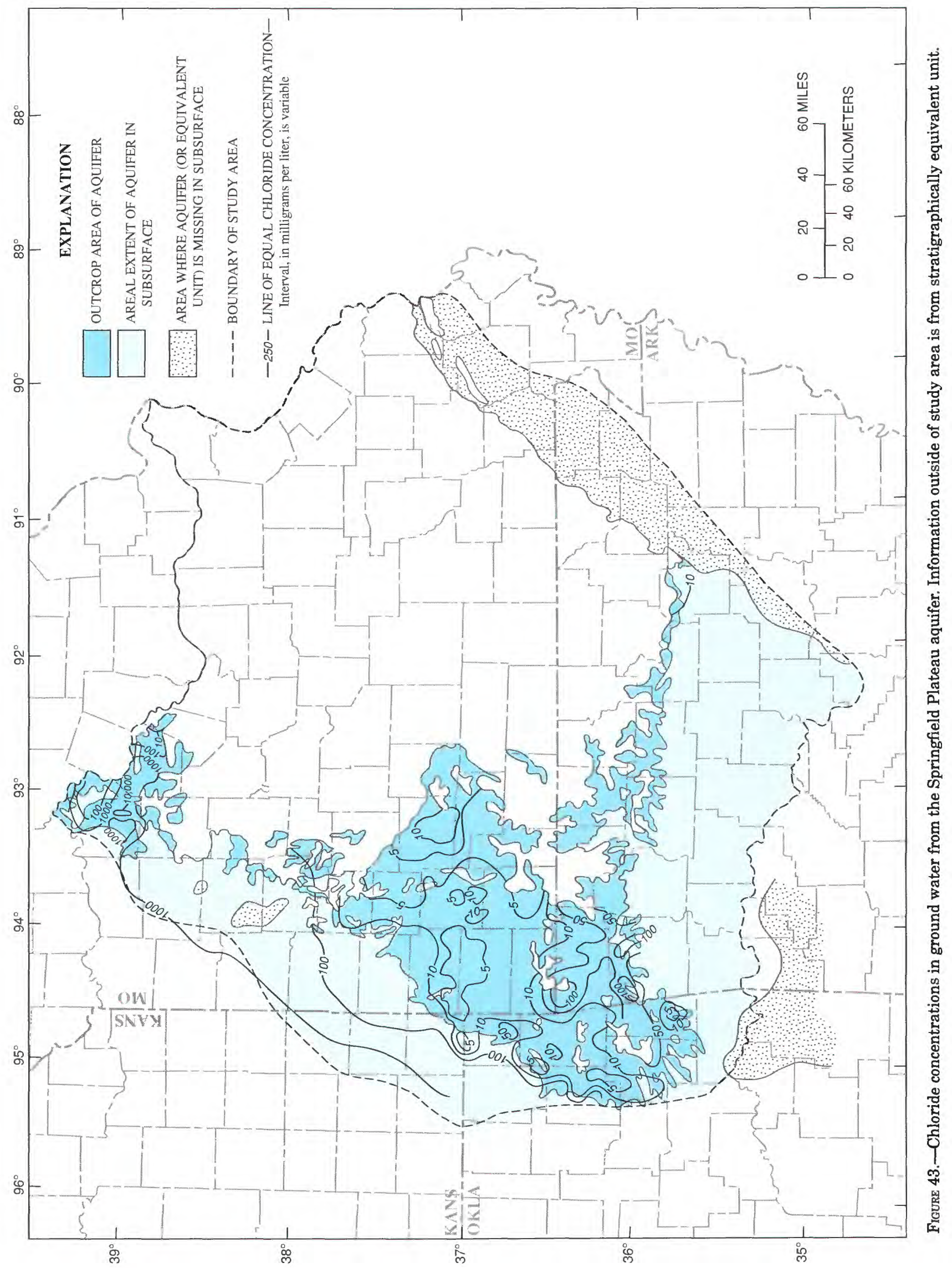




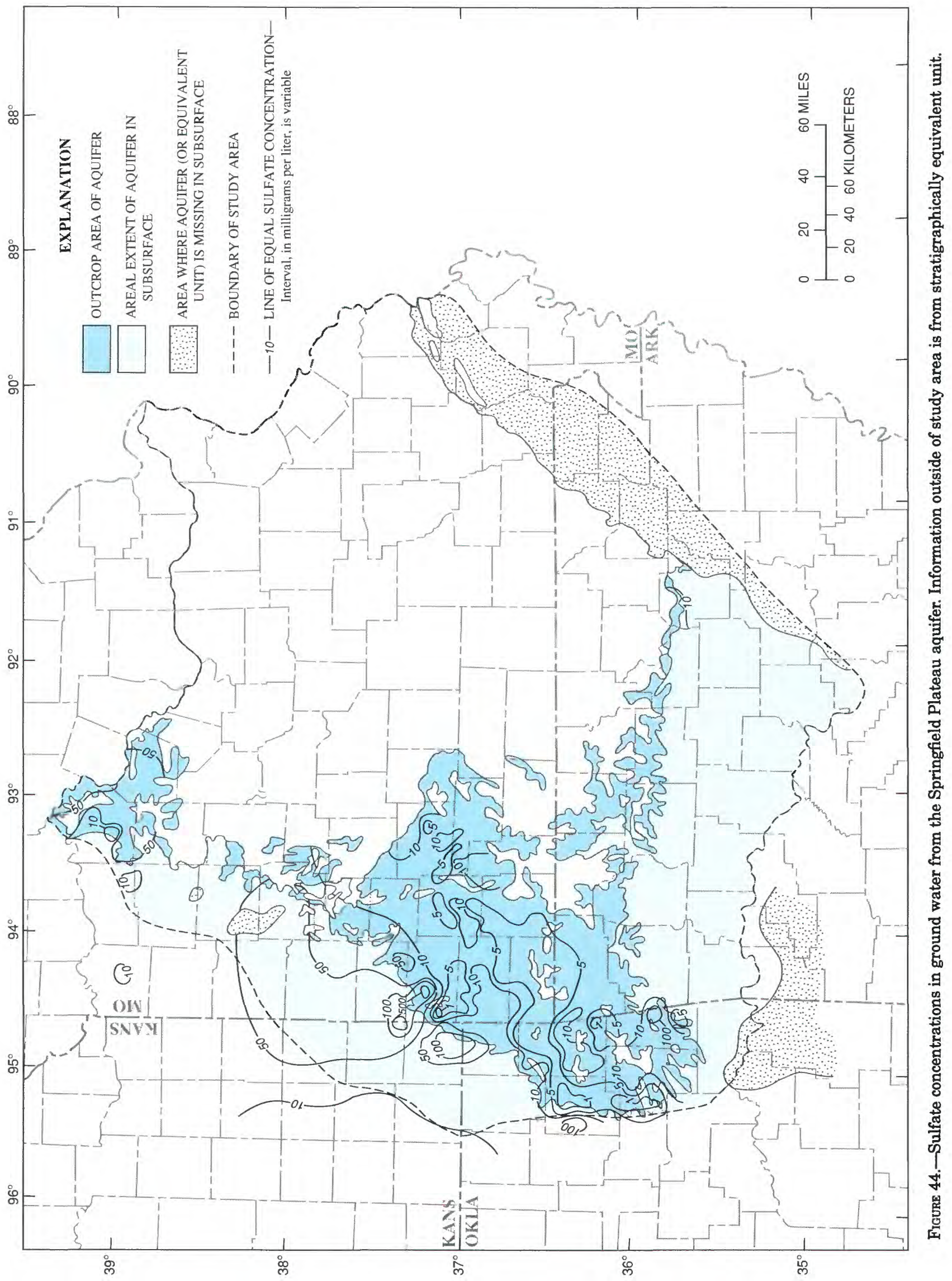




\section{WESTERN INTERIOR PLAINS CONFINING SYSTEM}

The Western Interior Plains confining system is a thick (as much as 20,000 ft) and areally extensive geohydrologic unit that extends from the Rocky Mountains to western Missouri and northern Arkansas (Jorgensen and others, 1993). This confining system overlies and effectively confines the extensive Western Interior Plains aquifer system (Jorgensen and others, 1993) west of the Ozark area. This confining system also confines the western and southern edges of the Ozark Plateaus aquifer system (figs. 11, 12).

Within the larger region encompassed by the study of the Central Midwest Regional AquiferSystem Analysis, this confining system includes rocks that range from Late Mississippian to Jurassic age, but along the western and southern flanks of the Ozarks, where the system confines the Ozark Plateaus aquifer system, it contains only Upper Mississippian and Pennsylvanian rocks. Within the study area, the Western Interior Plains confining system is represented by a sequence of rocks ranging from the Carterville Formation of Mississippian age to the Kansas City Group of Pennsylvanian age (table 1). Geologic formations that are stratigraphically equivalent to those that constitute the Western Interior Plains confining system are present in the north-central Salem Plateau and in the extreme northeastern part of the study area. Although these units have quite similar geohydrologic characteristics and significantly affect the hydrology of local areas in which they are present, they are not hydraulically continuous with the equivalent units in the western and southern parts of the study area and are, therefore, not designated as part of the Western Interior Plains confining system. In southwestern Missouri the Western Interior Plains confining system includes four Mississippian formations (the Carterville Formation, Hindsville Limestone, Batesville Sandstone, and Fayetteville Shale) and a sequence of Pennsylvanian formations from the stratigraphically lower Cherokee Shale to the Kansas City Group. Mississippian rocks are only a small part of the total thickness of the confining system. Only the Pennsylvanian formations are present in southeastern Kansas. In northeastern Oklahoma the confining system includes the stratigraphic sequence from the base of the Mississippian Hindsville Limestone to the Pennsylvanian Marmaton Group. In the Boston Mountains of northern Arkansas, the confining system extends from the basal Moorefield Formation to the McAlester Formation.

\section{Structural Features}

The Western Interior Plains confining system is stratigraphically the uppermost geohydrologic unit in the study area, excluding unconsolidated alluvium along streams and rivers and post-Paleozoic deposits of the Mississippi Alluvial Plain. Along the western boundary of the study area, the topography of the surface of the unit is characterized by gently rolling hills and broad alluvial valleys. The altitude of the top of the confining system ranges from less than 800 feet in the river valleys to more than 1,000 feet in the upland areas (fig. 45; Imes, 1990g). At the southern edge of the Ozark Plateaus, the surface of the confining system reflects the rugged topography of the Boston Mountains. It is common for the altitude of the top of the confining system to change by more than 1,500 feet within a few miles in the Boston Mountains. The altitude of the confining system ranges from less than 400 feet in the lowlands of the Arkansas Valley to more than 2,000 feet on highland ridges in the Boston Mountains. The confining system has been removed by erosion from the Mississippi Alluvial Plain in southeastern Missouri and northeastern Arkansas.

\section{THICKNESS}

Generally, the thickness of the Western Interior Plains confining system increases away from the Ozark Plateaus province. The unit thickens at a greater rate to the south than to the west. In the western part of the study area the confining system thickens at a fairly uniform rate of about 12 feet per mile to the northwest and is about 400 feet thick along the western edge of the Ozark Plateau aquifer system (fig. 46; Imes, 1990g). Irregularities in the thickness of the Western Interior Plains confining system near the western flank of the Springfield Plateau do not seem to conform to the surface drainage pattern and probably are an expression of erosional features on top of the underlying Springfield Plateau aquifer.

Near the Kansas-Oklahoma border, the confining system thickens at a rate of about 25 feet per mile to the west, and near the southwest edge of the study area the rate is about 80 feet per mile to the southwest. Only a narrow band of the Western Interior Plains confining unit is within the boundaries of the study area in northeastern Oklahoma. The rate of thickening of the unit away from the Ozark Plateaus is greater south of the Boston Mountains. In this area the confining system thickens at a rate of about 


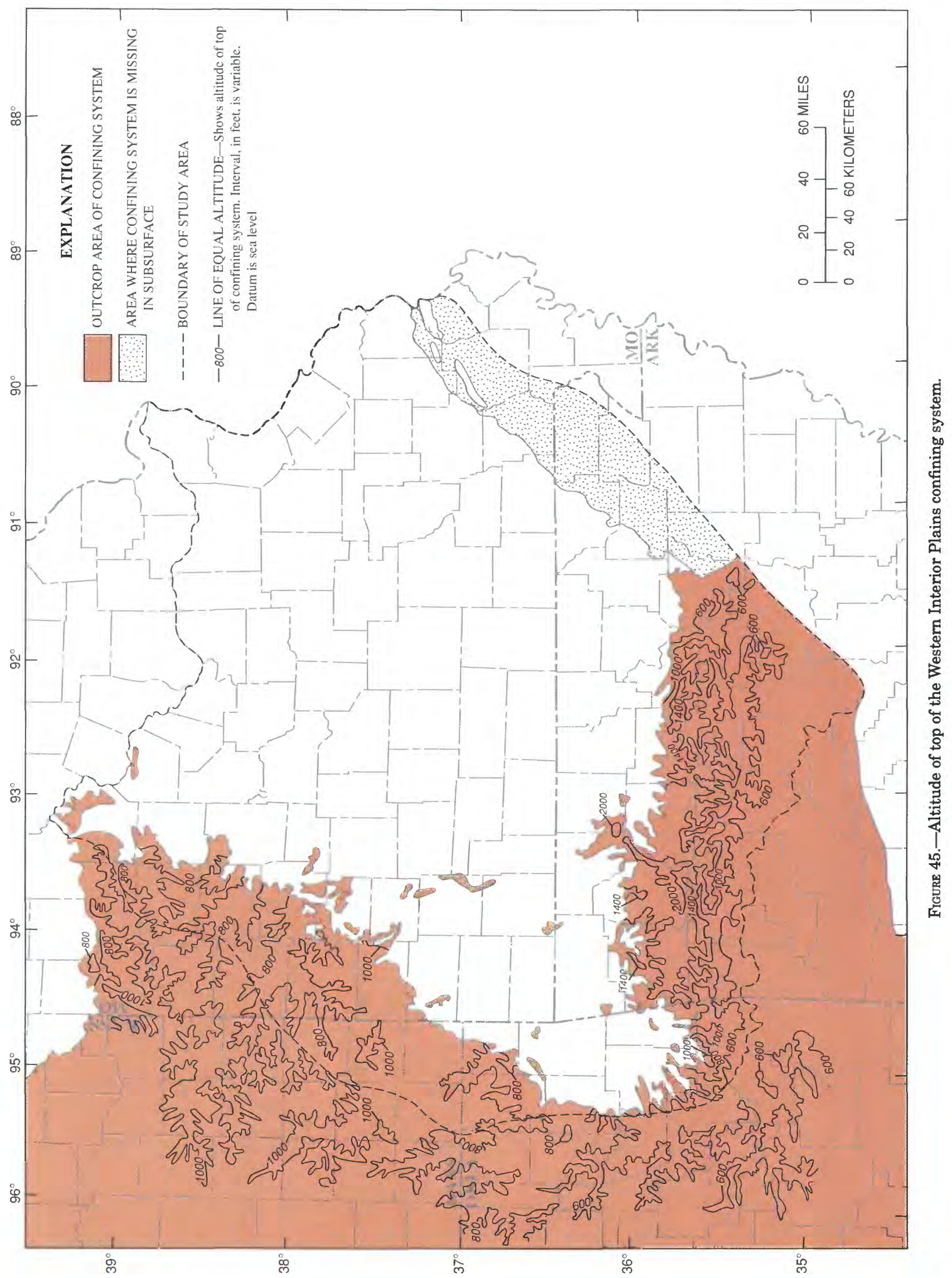




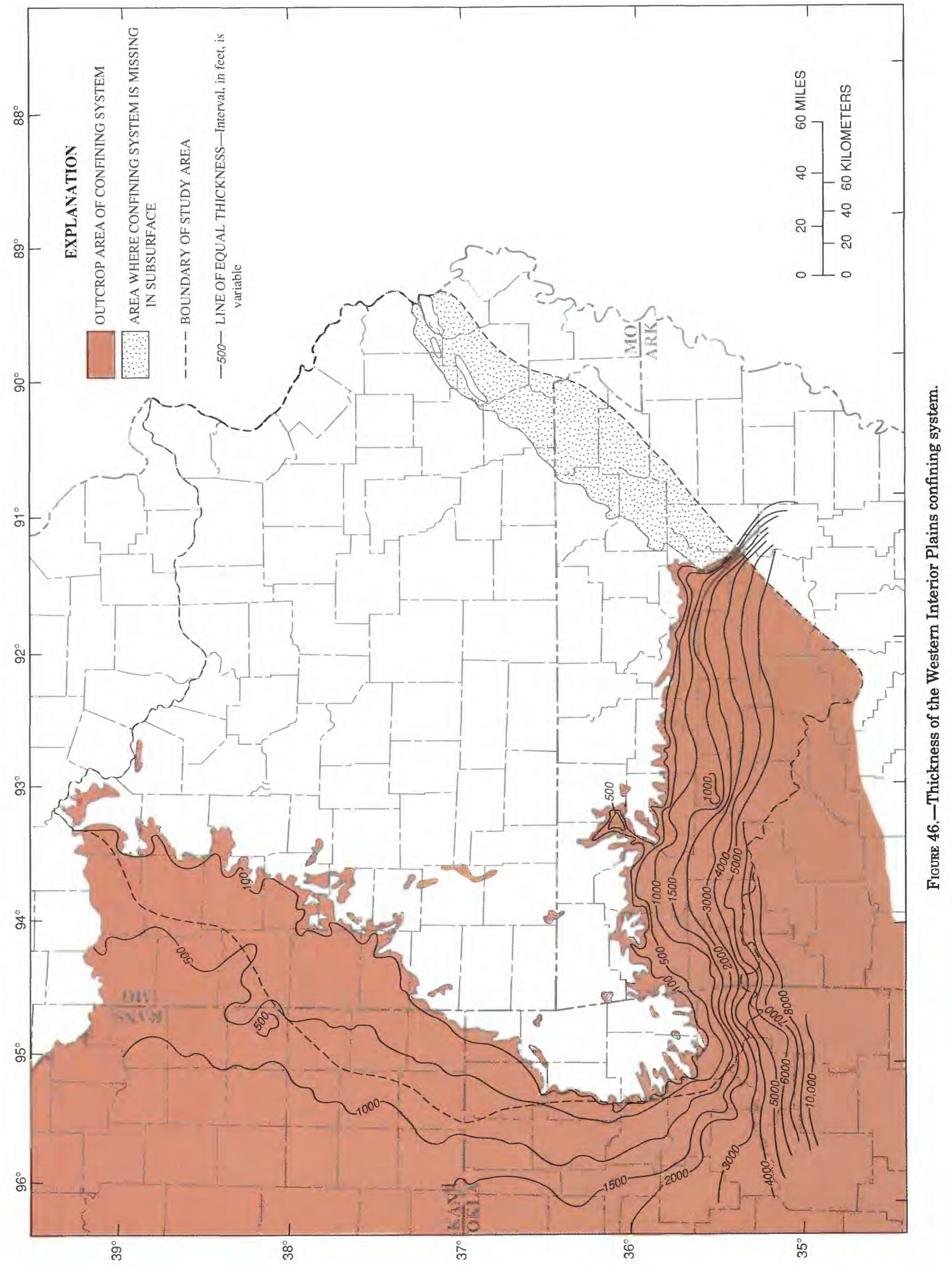


180 feet per mile to the south and is thicker than 6,000 feet beneath the Arkansas Valley.

Lithology and Geohydrologic Properties

The Western Interior Plains confining system consists of alternating sequences of low-permeability shale and low-permeability to relatively permeable limestone, sandstone, and coal. The less permeable rocks dominate the system and restrict vertical leakage and lateral movement of ground water. The more permeable rocks in the confining system do not form distinct aquifers regionally. Thus, the rocks that form the confining system collectively impede the flow of water to and from the underlying Ozark Plateaus aquifer system. It is plausible for a thick and complex geohydrologic unit, such as the Western Interior Plains confining system, to include local waterbearing aquifers and permeable zones. The designation "Western Interior Plains confining system" indicates that, on a regional scale, the rocks composing the unit impede the vertical flow of water and confine the underlying aquifers.

In Arkansas the stratigraphically lowest formation assigned to this confining system is the Moorefield Formation (table 1), because of its large shale content and low permeability. However, the shale content of this formation decreases to the west, and the formation is permeable enough to assign it to the Springfield Plateau aquifer in Oklahoma. The stratigraphically higher Batesville Sandstone, a calcareous sandstone containing some shale, is only slightly permeable because the sand grains are tightly cemented. Of the remaining Mississippian formations in the confining system, the Hindsville Limestone, Fayetteville Shale, and Pitkin Limestone are thickest and the most extensive. The Hindsville Limestone and Pitkin Limestone probably have a larger permeability than the other Mississippian rocks of the confining system and are not as effective in impeding the vertical flow of ground water. On the other hand, throughout northern Arkansas and northeastern Oklahoma the Fayetteville Shale is thick and contains a large fraction of shale (Caplan, 1954; Huffman, 1958). Thus, this shale restricts vertical ground-water flow in these two areas.

Pennsylvanian rocks constitute the greater part of the Western Interior Plains confining system, both in thickness and areal extent. The lithology of these rocks is predominantly shale; sandstone and limestone also are well represented. The leakance of this thick sequence of rocks is governed by significant quantities of slightly permeable shale. The rocks re- strict the movement of ground water between land surface and the underlying Springfield Plateau aquifer. Some of the larger sandstone formations, mostly those of the Cherokee Shale (table 1), are more permeable than other formations in the confining system. The near-surface weathered zone of the confining system has somewhat different hydraulic properties than the deeper, unweathered parts. Because the near-surface shale layers are fractured and slightly permeable, secondary permeability has developed in the near-surface limestone formations, and local ground-water flow systems are present in the upper 300 feet of the weathered confining system. This permeable layer contrasts with the consolidated and compacted lower part of the confining system.

Hydraulic heads in the Western Interior Plains confining system probably have changed little from their predevelopment levels. Even if the heads in a more permeable zone within the confining system were lowered by pumping of domestic wells, this head decrease would not necessarily reflect the hydraulic heads in other permeable zones in the confining system, because of the poor hydraulic connection among the zones. The head distribution within the confining system varies both vertically and laterally. Water-level measurements from wells that are open to most or all of the water-yielding layers of the confining system represent a weighted-average water level of the more permeable zones of the confining system. No single head value can represent hydraulic heads in the confining system because hydraulic gradients usually are nearly vertical in the low-permeability zones and nearly horizontal in the higher permeability zones.

\section{LATERAL Ground-WATER MOVEMENT IN THE NEAR-SuRface WEAThERED} ZONE OF THE Western INTERIOR Plains CONFININg SYSTEM

Heads in the near-surface weathered zone of the Western Interior Plains confining system are greatly affected by topographic features. Generally, groundwater supplies are replenished by precipitation that infiltrates the ground in upland areas and percolates to the water table. The ground water then flows downgradient toward lowland areas where it discharges into perennial streams. Ground-water levels in the upland areas tend to be as much as 100 feet lower than the average land-surface altitude. Near the northwestern boundary of the study area, ground water in the near-surface weathered zone of the Western Interior Plains confining system primarily moves towards the major valleys associated with the Blackwater, Marais des Cygnes, and South Grand 
Rivers (fig. 6). Heads in the river valleys generally are less than 800 feet above sea level. A groundwater divide that extends northwest from Barton County, Missouri (fig. 3), separates the ground-water flow in the northwestern part of the study area from the ground-water flow in a larger area to the southwest and south. In the latter area the ground water moves into the Neosho River in southeastern Kansas and northeastern Oklahoma and into the Arkansas River in northeastern Oklahoma and northern Arkansas (fig. 47). Water levels along the divide range from 800 to 1,000 feet above sea level, whereas water levels in the Arkansas River valley are less than 600 feet above sea level. In the Boston Mountains of northern Arkansas, heads in the weathered zone of the confining system vary markedly over relatively short distances. The altitude of ground-water levels exceeds 2,000 feet in the uplands of the Boston Mountains and decreases to less than 300 feet in the lower reaches of the Arkansas River valley.

The predevelopment head map shown here (fig. 47; Imes, $1990 \mathrm{~g}$ ) represents the head distribution in the near-surface weathered zone of the confining system and, therefore, indicates the approximate lateral movement of ground water in this zone. It does not represent the movement of ground water in the deeper layers of the confining system. Water-level measurements used in the construction of figure 47 generally are from wells that are open only to the upper 100 to 300 feet of the weathered zone of the confining system. The head data also reflect measurements at various times throughout this century, and thus the head distribution is only an approximation.

\section{UNNAMED LOCAL GEOHYDROLOGIC UNITS}

Mississippian and Pennsylvanian rocks stratigraphically equivalent to geohydrologic units previously defined and described, but not considered part of the regional geohydrologic units, are located in three areas in the northeastern part of the Ozark Plateaus province (fig. 48). These areas are labeled A (located in the north-central Salem Plateau), B (located in St. Louis and Jefferson Counties, Missouri (fig. 3)), and C (located in Ste. Genevieve and Perry Counties, Missouri). These rocks do not have a direct hydrologic relation with stratigraphically equivalent units in the western part of the Ozark Plateaus province. However, they have hydraulic properties that are similar to those of the regional geohydrologic units because they are composed of the same geological formations. Although some of these units are important as sources of domestic water supply in the northeastern part of the study area, the units are not extensive enough to be classified as one of the regional geohydrologic units.

Permeable Mississippian geologic formations, most of which are stratigraphically equivalent to those of the Springfield Plateau aquifer, crop out in areas B and $C$ (fig. 48) in eastern Missouri along the Missouri and Mississippi Rivers. They dip into the subsurface to the east. The formations, mainly composed of limestone, include those from the base of the Fern Glen Limestone to the top of the Ste. Genevieve Limestone (table 1). In area $\mathrm{B}$, the altitude of the top of the sequence generally decreases from nearly 700 feet where it feathers out against the Ozark confining unit to the southwest (fig. 12) to less than 400 feet along the Mississippi River and where it is confined by Pennsylvanian rocks in the northeast (fig. 49; Imes, 1990f). The unit thickens northeastward from its terminus at the outcrop of older rocks and is more than 900 feet thick at the center of a nearly circular depression in the northeast corner of the area. The unit yields water to domestic wells, especially in the southwestern half of the area where the dissolvedsolids concentration of the water is less than 1,000 milligrams per liter (Gleason, 1935). The distribution of water levels in the unit is affected by the topographic relief of the area, even where the unit is confined beneath Pennsylvanian rocks (fig. 49; Imes, 1990f). Water levels in the unit are greater (about $600 \mathrm{ft}$ ) in the southwest near the outcrop area of older rocks, and decrease to about 400 feet along the Missouri and Mississippi Rivers. Generally water levels are about 50 to 100 feet below land surface in the upland areas and at land surface along the major river valleys. In the southwestern part of the area, ground water from the unit recharges the Ozark aquifer, whereas in the northeastern part of the area, ground water in the Ozark aquifer discharges into this local unit.

Rocks in area $\mathrm{C}$, which are stratigraphically equivalent to those of the Springfield Plateau aquifer, crop out in a narrow band along the Mississippi River. The rocks dip abruptly to the east. The altitude of the top of the unit ranges from greater than 400 feet in the west to below sea level in the east (fig. 50; Imes, 1990f) where the unit is covered by alluvial deposits of the Mississippi River. In the same short distance, the thickness of the unit increases from near 0 to more than 1,500 feet (fig. 50; Imes, 1990f). The direction of the hydraulic gradient in this local geohydrologic unit is approximately northeast toward the Mississippi River valley where ground water discharges to the alluvium from the rocks (fig. 50; Imes, 1990f). The rocks probably receive ground water from 


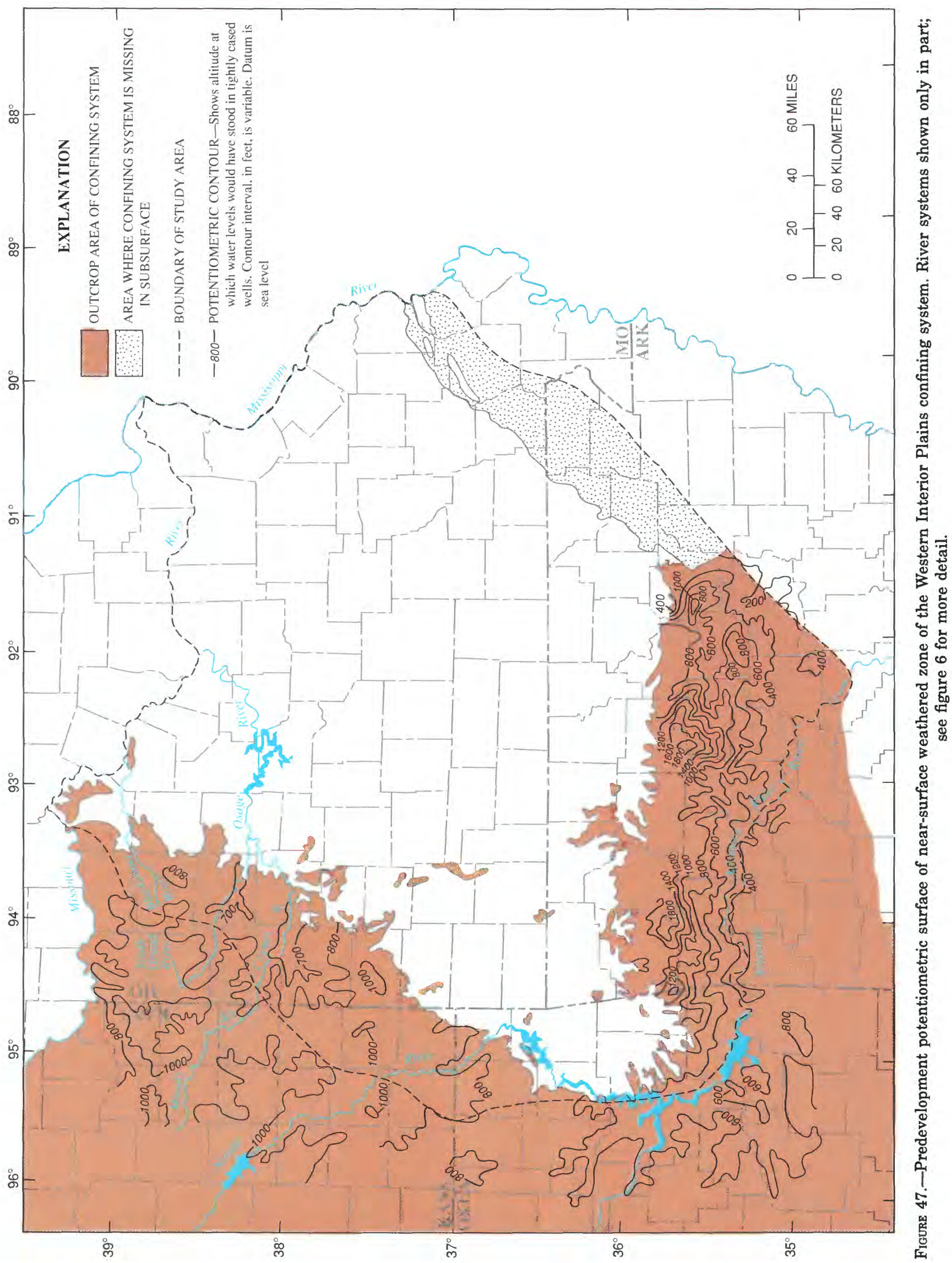




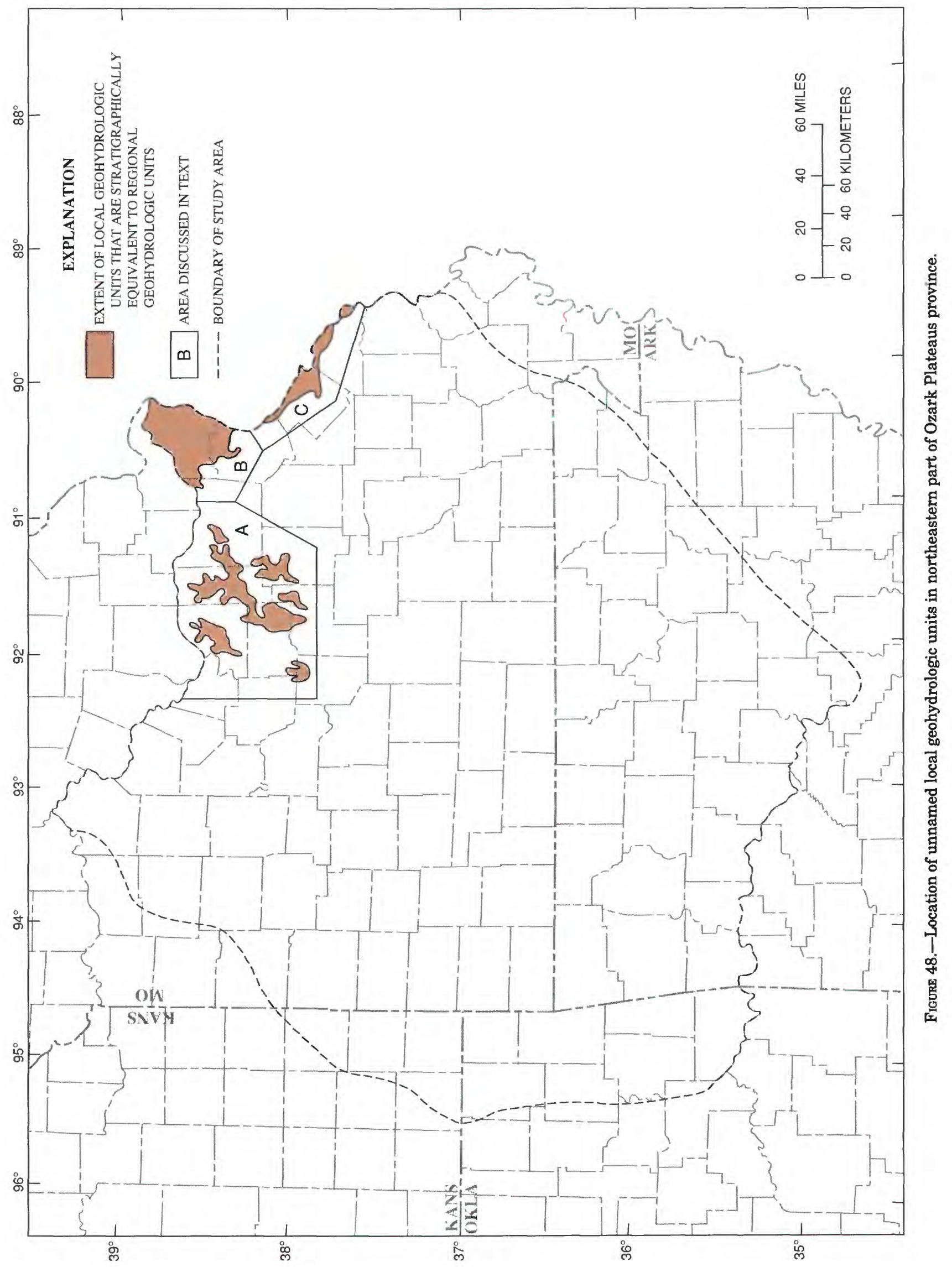


the underlying Ozark aquifer in all but the westernmost part of this area.

Geologic formations that are stratigraphically equivalent to the Western Interior Plains confining system occur in the areas of higher elevation between river valleys in the north-central part of the Salem plateau (area A) and are in direct contact with the Ozark aquifer. These undifferentiated Pennsylvanian rocks are the shallowest formations in the area and collectively confine the underlying Ozark aquifer. The top of these undifferentiated Pennsylvanian rocks reflects the gently rolling topography of the uplands. The altitude of the top generally ranges from 800 to 1,100 feet. The thickness of these rocks in this area rarely is more than 200 feet and usually is less than 100 feet. In the past, shallow wells (less than $25 \mathrm{ft}$ deep) were dug into these rocks to provide domestic water. Today these rocks are seldom used as a source of water because well yields are small, water quality has become degraded, and deeper wells provide high yields of better quality water.

Geologic formations that are stratigraphically equivalent to the Western Interior Plains confining system also are present to a limited extent in areas $\mathrm{B}$ and $\mathrm{C}$. The rocks, which form the surficial geohydrologic unit in this area, generally are not used as a source of water. Pennsylvanian rocks (the Cherokee Shale, Marmaton Group, and Pleasanton Formation (table 1)) form a large, nearly circular confining system in the northeastern part of area B. The lensshaped system is about 250 feet thick at its center. The altitude of the top of these rocks ranges from about $\mathbf{4 5 0}$ feet near the Missouri and Mississippi Rivers to about 600 feet near the center of the lens (Imes, 1990g). In area C, rocks that are stratigraphically equivalent to the Western Interior Plains confining system crop out in a narrow band along the Mississippi River. In this small area the unit consists of a thick sequence of Upper Mississippian rocks from the Aux Vases Sandstone to the Vienna Limestone (table 1). The altitude of the top of the unit decreases from more than 400 feet adjacent to the outcrop of the Ozark Plateaus aquifer system to the west to less than 200 feet beneath the Mississippi River. The thickness of the unit increases eastward from 0 to more than 300 feet (Imes, 1990g).
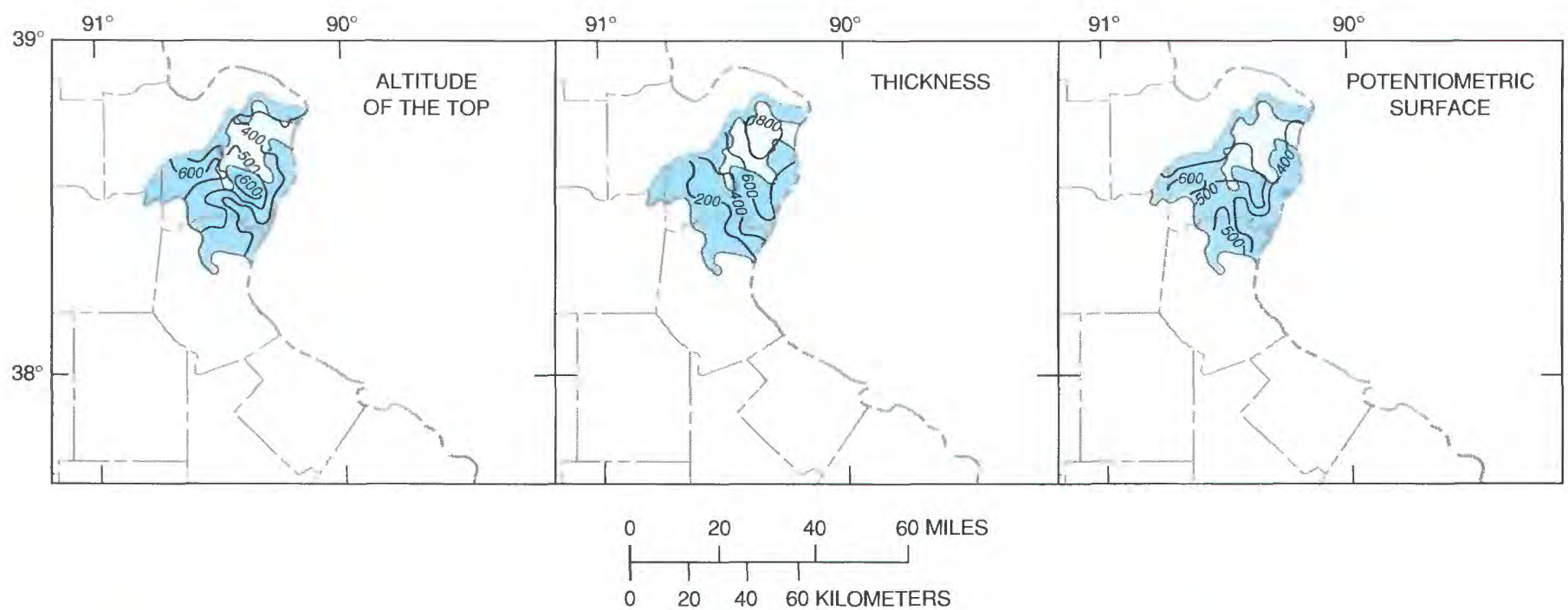

EXPLANATION

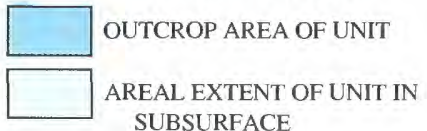
SUBSURFACE

- 400- LINE OF EQUAL ALTITUDE-Shows altitude of top of unit. Interval is 100 feet. Datum is sea level
EXPLANATION

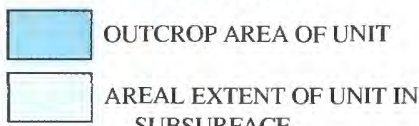

- 200- LINE OF EQUAL THICKNESSInterval is $200 \mathrm{feet}$
EXPLANATION

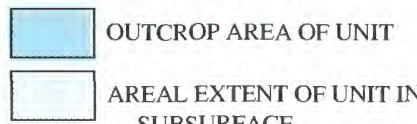
SUBSURFACE

- 400 - POTENTIOMETRIC CONTOUR-

Shows altitude at which water

levels would have stood in tightly cased wells. Contour interval is 100 feet. Datum is sea level

FIgURE 49.-Altitude of top, thickness, and potentiometric surface of rocks in area B (fig. 48) that are stratigraphically equivalent to the Springfield Plateau aquifer. 


\section{POST-PALEOZOIC DEPOSITS}

Unconsolidated, post-Paleozoic deposits, especially alluvial sand and gravel along the major river reaches that border much of the study area, are a valuable source of large quantities of ground water in the area. Although an investigation of the alluvial aquifers is not part of this study, the alluvial aquifers are briefly described here because of their hydrologic relation to the Ozark Plateaus aquifer system. In this section, the alluvial deposits of each river reach are treated as if the entire width of the alluvial valley, except the Mississippi Alluvial Plain physiographic section, were within the boundaries of the study area. More detailed information about these aquifers may be found in published literature, some of which is cited in the following paragraphs.

Alluvial deposits associated with many small streams and rivers in the interior of the study area generally are narrow to absent. Water in these alluvial deposits is used for public supply by small towns and, principally, as a source for domestic use. Along the boundary of the study area, three large rivers and their alluvial deposits supply large quantities of water to municipal, industrial, and domestic users. Along the northern boundary the Missouri River alluvium varies from about 1.5 to 6 miles in width and averages about 90 feet in thickness. Sand and gravel deposits are predominant in the lower part of the alluvium, and sand and clay are predominant in the upper part. Yields as large as 3,000 gallons per minute have been reported for wells penetrating the more permeable gravel beds (Emmett and Jeffery, 1968, 1969). The Mississippi River alluvium along the eastern boundary is hydrologically similar to the alluvium of the Missouri River. The Arkansas River valley coincides with the southern boundary and part of the southwestern boundary of the study area. The sand, gravel, silt, and clay deposits along this reach of the Arkansas River range from about 40 feet thick at the Oklahoma-Arkansas border to about 80 feet thick where the river intersects the Mississippi Alluvial Plain. Eight aquifer tests at various locations in the alluvium of the Arkansas River valley indicate that the transmissivity ranges from 0.06 to 0.25 foot squared per second (Bedinger and others, 1963).
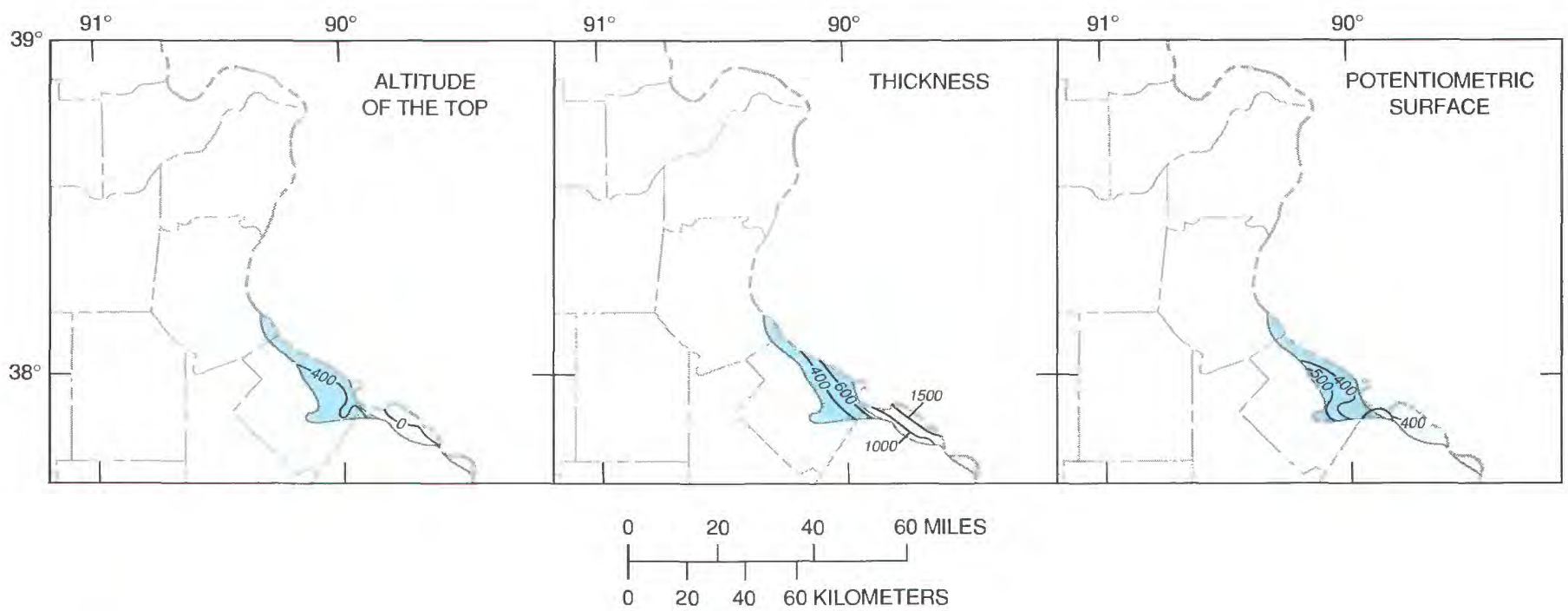

EXPLANATION

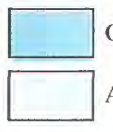

OUTCROP AREA OF UNIT

AREAL EXTENT OF UNIT IN SUBSURFACE

- 400- LINE OF EQUAL ALTITLDE-Shows altitude of top of unit. Interval is 400 feet. Datum is sea level
EXPLANATION

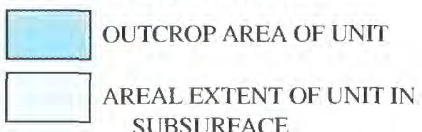
SUBSURFACE

— 400- LINE OF EQUAL THICKNESSInterval, in feet, is variable
EXPLANATION

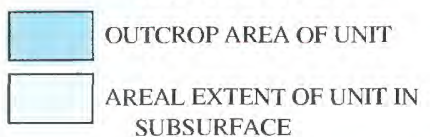
SUBSURFACE

- 400- POTENTIOMETRIC CONTOURShows altitude at which water levels would have stood in tightly cased wells. Contour interval is 100 feet. Datum is sea level

Figure 50.-Altitude of top, thickness, and potentiometric surface of rocks in area C (fig. 48) that are stratigraphically equivalent to the Springfield Plateau aquifer. 
The thick unconsolidated sediments of the Mississippi Alluvial Plain along the southeastern boundary of the study area provide large quantities of water for public water supply and agricultural use. The Cretaceous, Tertiary, and Quaternary sediments of the alluvial plain thicken to the southeast. Yields from wells open to the alluvial aquifer commonly range from 1,000 to 2,000 gallons per minute and may exceed 4,000 gallons per minute locally. Analyses of aquifer tests at nine locations in the alluvial aquifer in Missouri indicate the transmissivity of the aquifer ranges from 0.17 to 0.63 foot squared per second (Luckey, 1985). The geology and hydrology of the alluvial aquifer and the underlying unconsolidated post-Paleozoic sediments have been studied extensively (Cushing and others, 1964; Luckey and Fuller, 1980; Luckey, 1985; and Petersen and others, 1985). The area currently is being investigated in detail as part of the Gulf Coast Regional Aquifer-System Analysis (Grubb, 1984).

\section{INTERACTION OF SURFACE AND GROUND WATER: RECHARGE TO THE REGIONAL GROUND-WATER FLOW SYSTEM}

The exchange of surface water and ground water is a function of the relative altitude of land surface and the water table. Generally, recharge occurs by infiltration of precipitation where the water table is lower than the land surface; discharge occurs by surface flow where the water table intersects the land surface or by evapotranspiration where the water table is near the land surface. Because of seasonal variations in precipitation, the altitude of the water table can fluctuate as much as several tens of feet. A schematic diagram that represents the exchange mechanisms that are important in the Ozark Plateaus province is shown in figure 51.

Most of the water that percolates to the saturated zone moves laterally through shallow, local flow systems; it then discharges into streams as base flow or issues through small springs. Of importance to this study is the smaller quantity of water that moves vertically downward to the deeper, regional groundwater flow system. To estimate the quantity of water that percolates to the deep, regional flow system, it is necessary to estimate some of the flow components in the shallow aquifer system. In practice it is difficult, if not impossible, to estimate these flow components, especially where the thickness of the aquifer system is large and the structure and lithology of the geologic formations composing the aquifer system are complex. Fracture systems and large faults can provide hydraulic connections between shallow and deep flow systems and thus can further complicate their interaction.

In the Interior Plains, Boston Mountains, and Arkansas Valley (fig. 5), surficial geologic materials of the uppermost Western Interior Plains confining system are predominantly slightly permeable shale and permeable sandstone with some permeable limestone. Weathering processes in the near-surface zone of the confining system have reduced permeability contrasts between different rocks. The more uniform hydraulic properties and generally small hydraulic conductivity of the rocks in the confining system create a geohydrologic condition that supports a welldefined, near-surface water table controlled by the local topographic features of the area. Contours on the water table (Imes and Smith, 1990) tend to parallel rivers and streams and reflect the infiltration of precipitation in the uplands, movement of shallow ground water from the uplands to adjacent valleys, and discharge of the ground water into streams by seepage.

The Springfield Plateau is characterized by a deeply weathered cherty limestone that contains a welldeveloped, near-surface karst. The water table generally is easy to define in this area, with water-level contours usually trending parallel to the local surface topography (Imes and Smith, 1990). Most streams in the area gain water by ground-water discharge from the Springfield Plateau aquifer. However, there are stream reaches that lose water to adjacent aquifers. The lost water typically resurfaces downstream in the same channel.

An extensive karst system has developed in the Ozark aquifer where it crops out in the Salem Plateau (figs. 5, 12, 52). The large thickness of carbonate rock and extensive network of solution-enlarged fractures, vertical joints, and bedding planes enables surface water to rapidly infiltrate the Ozark aquifer. Major conduit systems, many of which are several feet wide and hundreds of feet long, occupy the upper few hundred feet of the aquifer. Caverns and large springs abound in this part of the Ozarks (Vineyard and Feder, 1974). Harvey (1980) identified areas in southern Missouri and northern Arkansas where the Ozark aquifer contains large concentrations of sinkholes. The well-developed (primary) karst areas are defined as having more than 10 sinkholes per 100 square miles, whereas areas of lesser developed (secondary) karst are defined as having 1 to 10 sinkholes per 100 square miles (fig. 52). Solution of limestones and dolostones can produce complex and irregular surface and shallow-subsurface drainage patterns. Consequently, in many areas of the Salem Plateau 
where the karst is well developed, the water table may not reflect the local topography. The geometry of the water table in carbonate rocks that contain a well-developed system of solution channels or karst terrane can be difficult to determine. Because of the abrupt changes in permeability, ground water can be perched above a less permeable zone. The presence of large areas of perched water can create two or more near-surface ground-water flow systems within the same area, with ground water in each perched area flowing in different directions along different conduit networks. An example of this phenomenon is shown by dye-trace data from the southernmost parts of the Salem Plateau (Harvey, 1980). The areally limited, possibly temporary, perched ground-water flow cannot be easily differentiated from the deeper, continuous regional flow.

On the other hand, the degree of karst development can enhance the interaction between surface and ground waters. This is illustrated in figures 53 and 54. Figure 53 depicts the effects of precipitation on the water level in an observation well located in Phelps County, Missouri, in the north-central part of the Salem Plateau (fig. 52). This well is 650 feet deep and cased to a depth of 420 feet in the Ozark aquifer. The aquifer in this area contains some solution channels, but the karst terrane is not well developed. The seasonal response to precipitation is about 20 to 25 feet. There is little evidence of any immediate response to individual precipitation events. In contrast, the response of the water levels shown in figure 54 is immediate and large. This well is located in welldeveloped karst in Howell County, Missouri, in the south-central part of the Salem Plateau (fig 52). It is 1,305 feet deep and cased to a depth of 800 feet of the Ozark aquifer. The mean annual precipitation at both wells is about 42 inches per year. Variations in the water level of the Howell County well can exceed 170 feet within a few days after a large rainfall. The well-developed karst of this area allows surface and ground water to interact rapidly to great depths.

The Ozark Plateaus province contains one of the largest concentrations of springs in the United States (fig. 55). Thousands of springs yield from less than a gallon of water per day to millions of gallons per day. Few of the springs are monitored

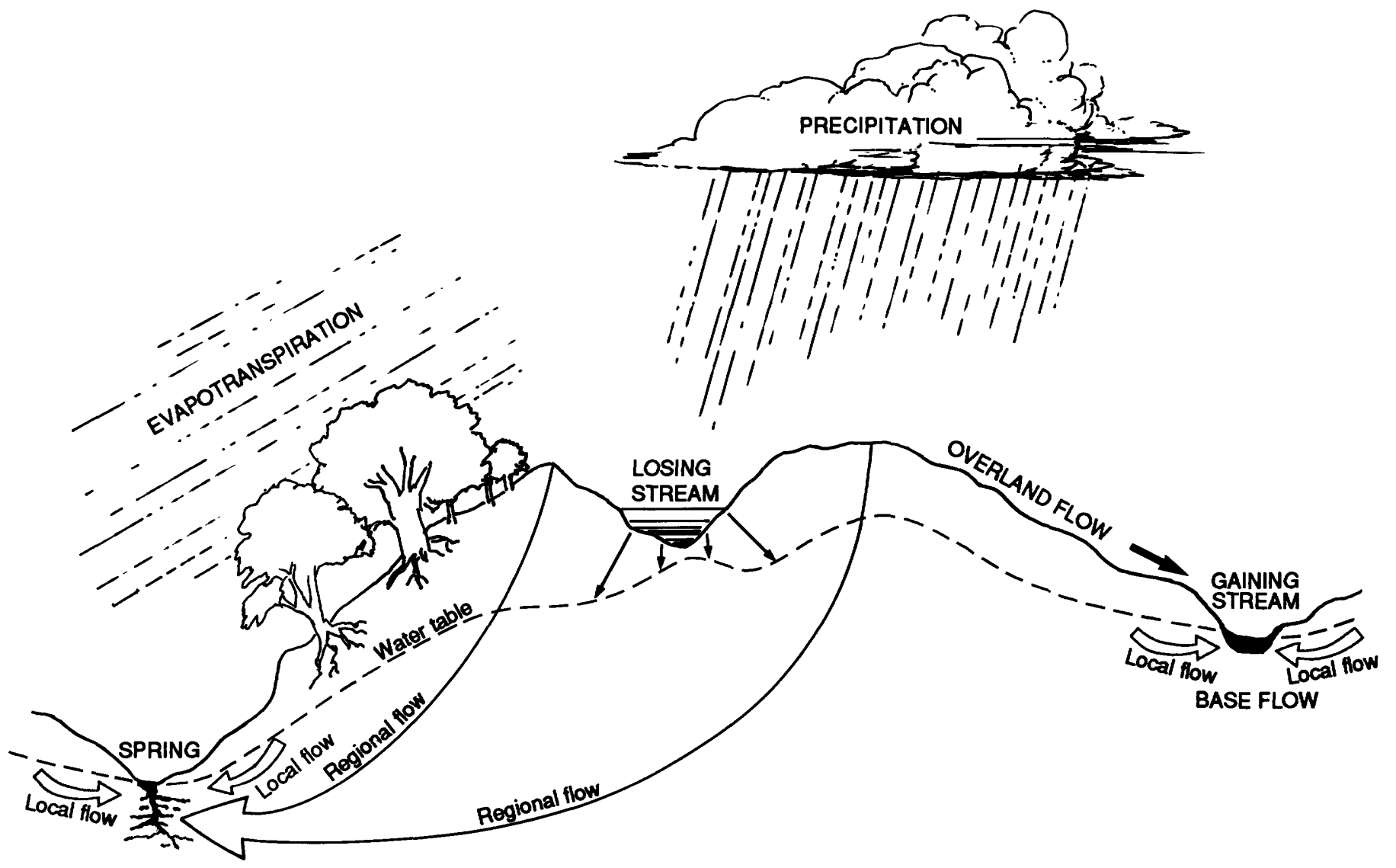

FIGURE 51.-Schematic diagram of surface- and ground-water exchange mechanisms in Ozark Plateaus province. 


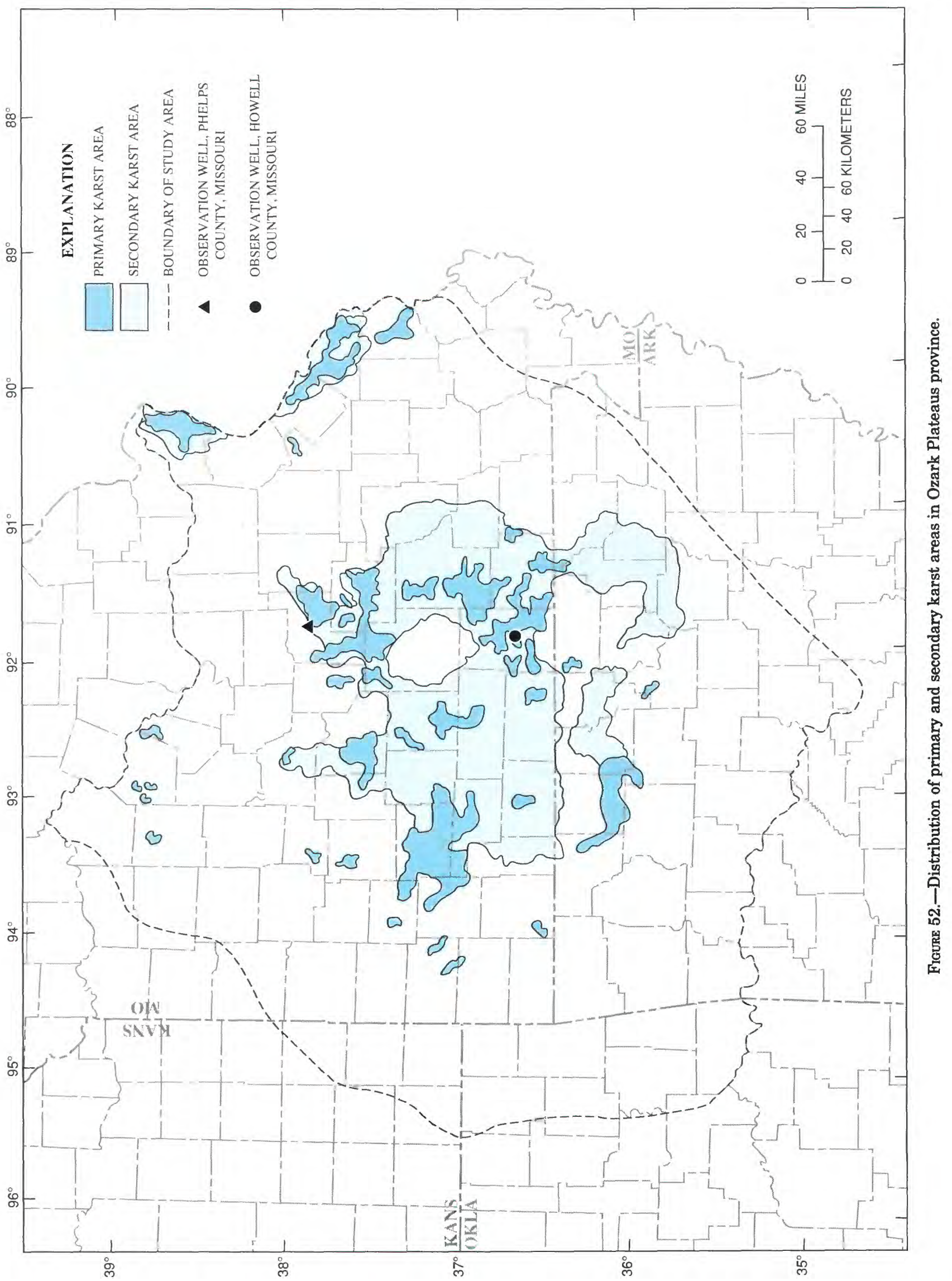


continuously; therefore, much of the available springflow data is a composite of (1) average flow over the period of record at springs where continuous measurements were made for some specific time interval and (2) instantaneous flow at those springs where continuous measurements have not been made. The combined flow of the ten largest springs in the Ozarks is about 2,000 cubic feet per second ( 1.3 billion gallons per day). Nine springs in the Ozarks are first-order springs, that is, they have an average discharge greater than or equal to 100 cubic feet per second (Meinzer, 1923). Many of the largest springs rise from nearly tubular conduits several feet wide that descend several hundred feet beneath land surface and connect the rise pool of the spring to deep-seated solution-channel networks. With few exceptions, the springs are confined to physiographic regions where carbonate rocks are the dominant surficial material.

The catchment areas of many large springs cover tens of square miles and do not necessarily coincide with surface-water drainage boundaries. In many cases the presence of a spring catchment area is indi- cated by sinkholes and losing streams. Although not as striking or as apparent as sinkholes, losing streams are common throughout the Salem and Springfield Plateaus (Imes and Smith, 1990). Losing streams are defined by the Missouri Department of Natural Resources (1985) as those streams or stream reaches that lose 30 percent or more of their flow through natural processes such as leakage through a permeable soil or bedrock. This definition is proposed as part of regulations concerning the movement of sewage effluent. Many streams lose smaller percentages of their flow to underlying aquifers or permeable material. The areas having the greatest concentrations and longest reaches of losing streams are located in the central part of the Salem Plateau. Not surprisingly, this area also contains some of the best developed karst in the Ozark aquifer. Because of the large hydraulic conductivity of the solution-channel networks that connect sinkholes and losing streams to springs, the response of springflow to precipitation in the catchment area can be rapid. During periods of dry weather, springflow in the larger springs is maintained by base flow from the aquifers.

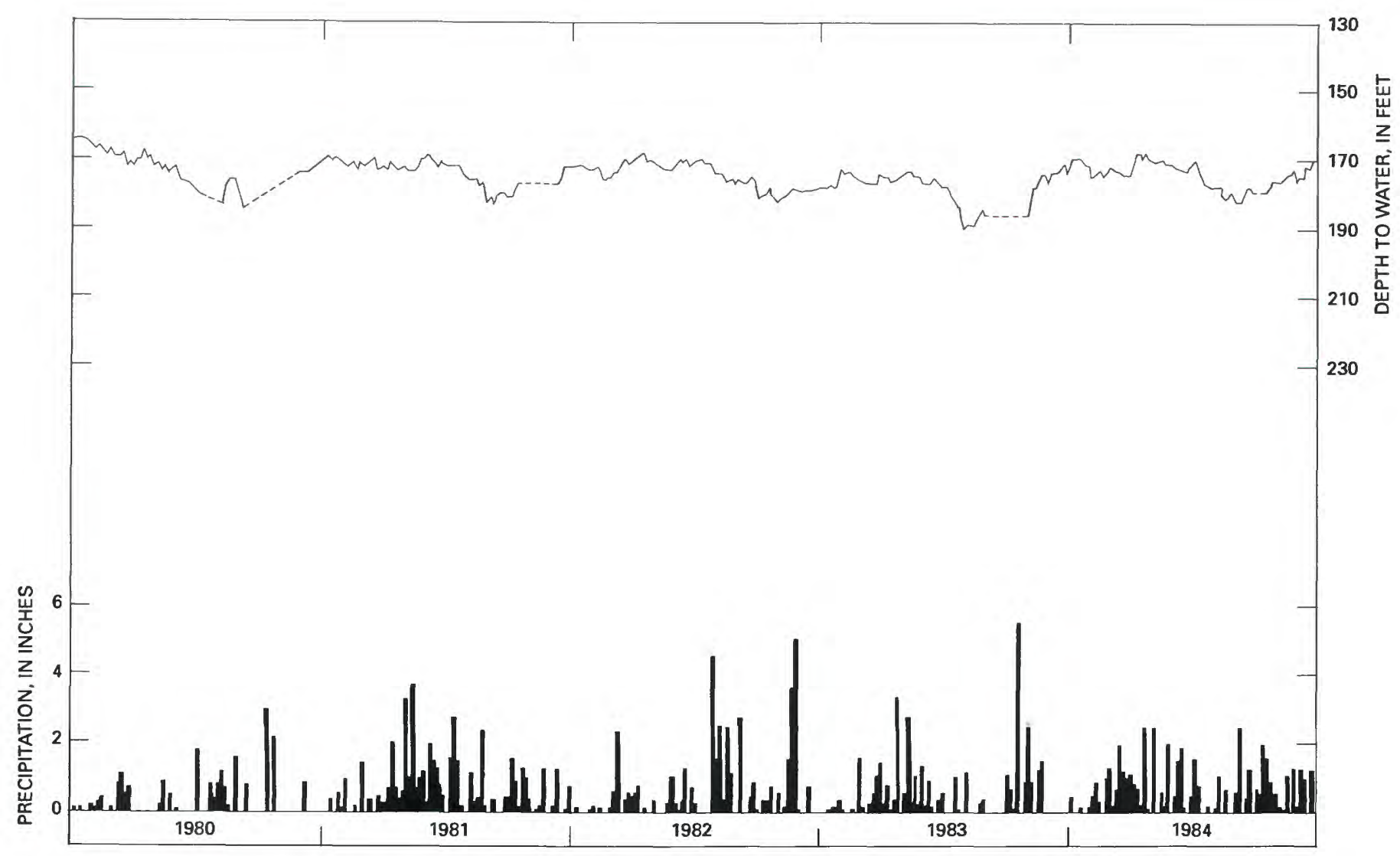

FiguRE 53.-Effect of precipitation on water levels in observation well in Phelps County, Missouri. Dashed segments in depth curve indicate periods during which no data were collected. See figure 52 for location of well. 
The largest springs issue from the Ozark aquifer. Most of the larger springs issue from the Potosi, Eminence, and Gasconade Dolomites (table 1). The springs, generally located in or near major river valleys (fig. 55), are points of discharge of both local and regional flow in the Ozark aquifer. The large discharge of many of the springs reflects the depth and areal extent of the karst terrane. Water-quality analyses of samples from springs in and near Saline County, Missouri (fig. 3), indicate that the spring water there flows from the underlying confined Ozark aquifer. Most of these springs are characterized by a large mineral content. Springs that receive most or all of their water from the uppermost part of the aquifer generally are less mineralized. Springs that flow from the Springfield Plateau aquifer are numerous, but not as large as those that flow from the Ozark aquifer.

The small number of springs that issue from the Ozark confining unit probably receive their water from the underlying Ozark aquifer. Some small springs are located in the Western Interior Plains confining system. These springs issue mineralized water because the water has been in contact with shale and coal. The ground water in the confining system moves to the springs through small fractures and along bedding planes and shale partings of the near-surface weathered zone of the confining system.

\section{ESTIMATES OF RECHARGE AND DISCHARGE}

An estimate of the amount of water that percolates through the unsaturated zone to the water table in the Central Midwest region has been made by Dugan and Peckenpaugh (1986). This estimate was made on the basis of climate, soil type, slope, land use, and consumptive water use by crops and vegetation. The estimate showed that mean annual ground-water recharge under preagricultural land-use conditions (that is, in woodland and grassland) ranged from about 7 to 15 inches per year in the Ozark area, and recharge generally increased from the northwest to the southeast (fig. 56). Today's mean annual groundwater recharge varies little from that estimated for preagricultural times, the largest change being about a 10-percent decrease in recharge in southwestern Missouri and northwestern Arkansas. The estimate

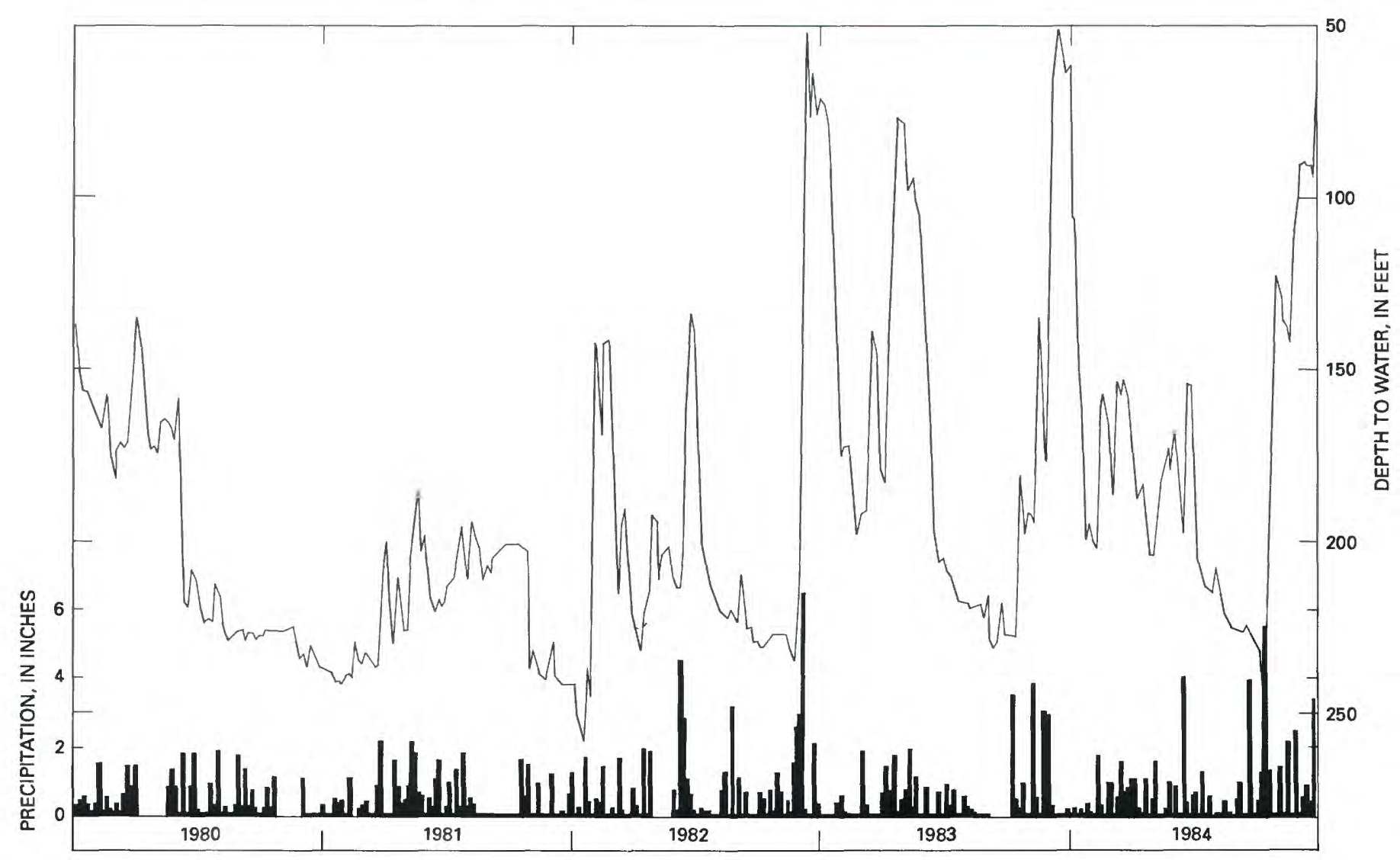

FigURE 54.-Effect of precipitation on water levels in observation well in Howell County, Missouri. See figure 52 for location of well. 


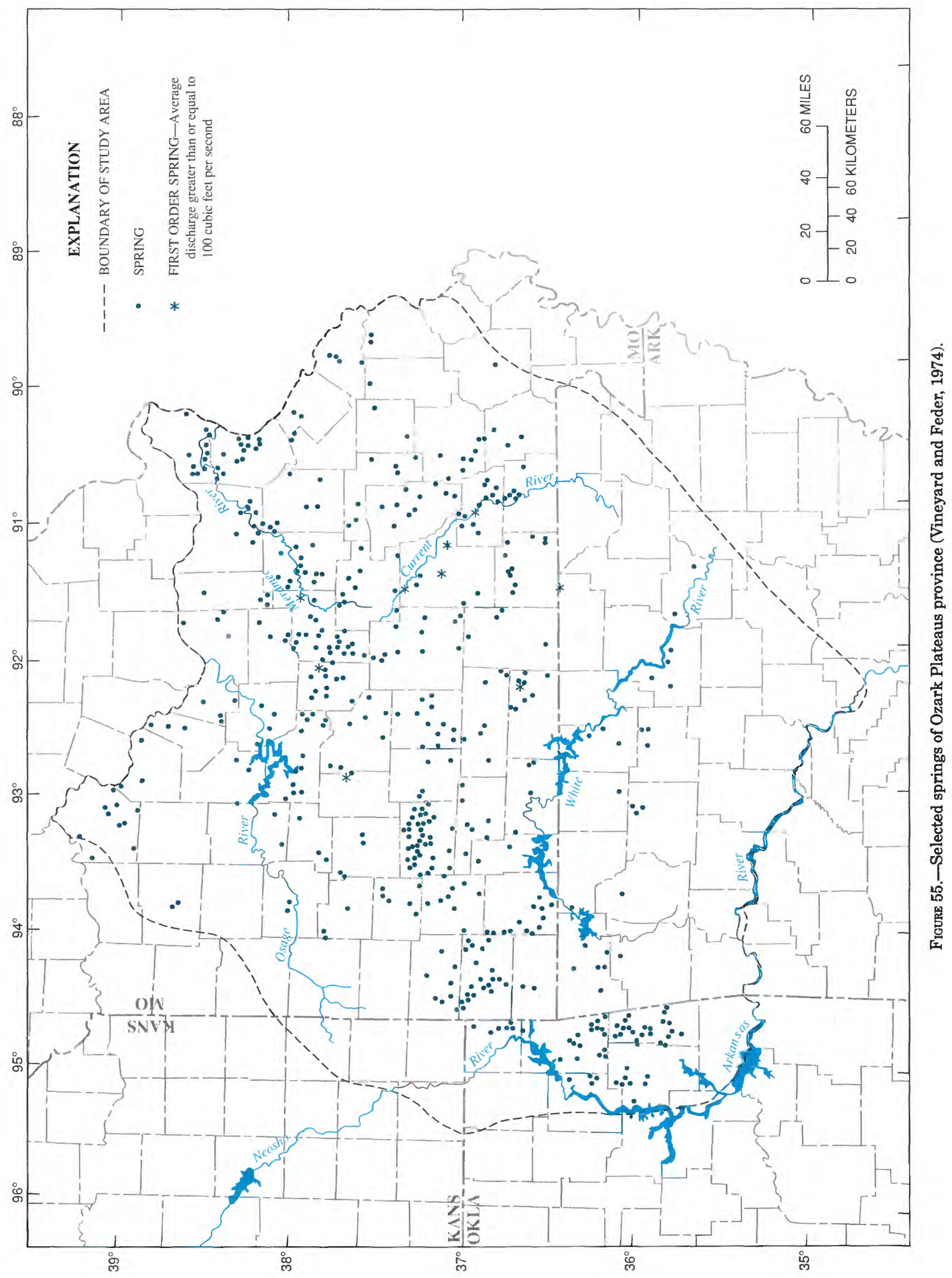




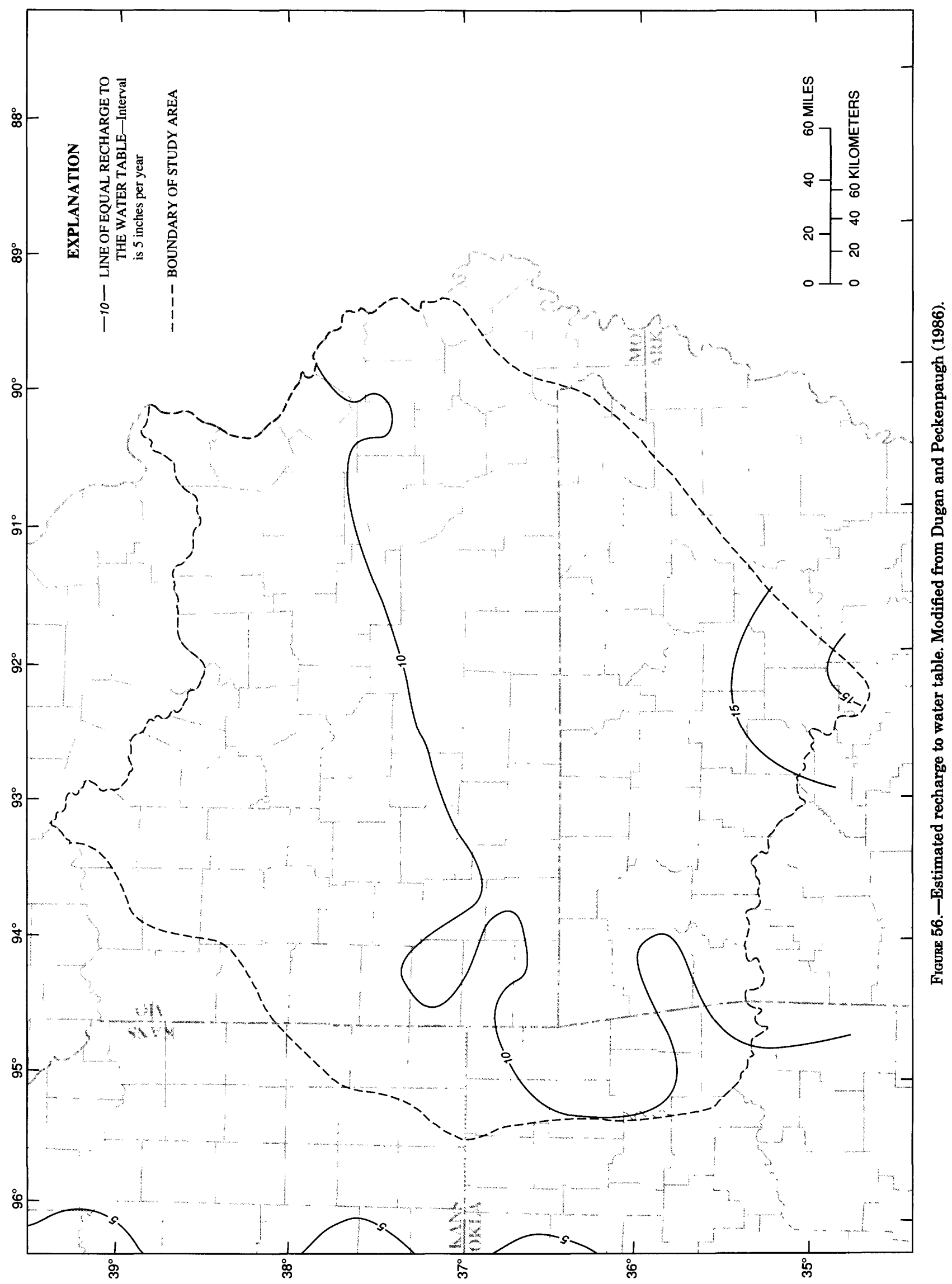


made by Dugan and Peckenpaugh does not attempt to distinguish the recharge to the water table and the recharge to the deep aquifers.

Measurements of flow in perennial springs and streams when overland flow is minimal provide an estimate of the amount of ground-water discharged as base flow. Hedman and others (1987) investigated the low-flow characteristics of Ozark streams and springs to determine the distribution of ground-water discharge in small basins. Several types of surfacewater-flow records were available for their analysis. Flow-duration curves were developed for the 177 basins in the Ozark area where continuous-record springflow- and streamflow-gaging stations provided values of mean daily flow; low-flow frequency data also were derived for these basins. Partial-record springflow and streamflow data and miscellaneous measurements were analyzed for another 161 basins. The partial-record flow data were correlated graphically with discharge records at nearby continuousrecord stations to estimate flow at recurrence intervals that represent the low-flow at the partial-record stations. Seepage-run measurements were made to estimate flow at different recurrence intervals at ungaged sites within some of the gaged basins. A significant conclusion reached by Hedman and others (1987) is that mean annual water loss (the difference between annual precipitation and annual runoff) in the Ozark Plateaus is relatively constant at 29 to 30 inches per year despite the large variation in annual precipitation (38 to 50 inches per year) across the Ozarks. This generally constant mean annual water loss probably is due to deep and extensive karst in the area. Exceptions to the constant mean occur in areas where a large amount of ground water moves between two or more surface-water drainage basins.

Although low-flow estimates were made by investigators for many small basins in the Ozarks, a large number of basins still are lacking such measurements. A statistical technique was developed by E.R. Hedman (U.S. Geological Survey, 1985, written commun.) to estimate the net ground-water discharge and recharge for the remaining basins. Hedman analyzed flow-duration curves to obtain a population of Ozark basins not having excessive ground-water gains or losses. He excluded those basins with unusually steep flow-duration curves (indicating a lack of regional base flow and loss of potential local base flow through the permeable karstic surficial aquifer) and those with flattened curves (indicating a regional base-flow component). Thus he identified a population of 100 basins that, he concluded, do not receive significant regional base flow and do not contribute to interbasin exchange of ground water, but are pri- marily characterized by local base flow. Low-flow frequency data from these basins were used to develop an empirical relation between combined overland runoff and local base flow (as defined by measured total runoff for the 100 basins) and precipitation for the Ozark Plateaus. Empirical linear, semilogarithmic, and logaritlımic relations were also developed for several low-flow frequency characteristics such as recurrence data (7-day $Q_{2}$, 7-day $Q_{10}$ ) and duration data $\left(Q_{70}, Q_{90}\right.$, and $\left.Q_{95}\right)$. The linear mathematical relation using 7-day $Q_{2}$ as the low-flow characteristic had the highest correlation coefficient $(0.75)$. The regression equation is shown below.

$$
\left(Q_{\mathrm{o}}+Q_{\mathrm{lf}}\right)=0.924 P-27.1 \text {, }
$$

where

$Q_{0}$ is annual overland runoff in inches,

$Q_{\text {If }}$ is the annual local component of base flow in inches, and

$P \quad$ is annual precipitation in inches.

Precipitation is the only independent variable in the above equation; other basin parameters, such as slope, are not involved in the equation. This fact may not limit the use of the equation because precipitation is the dominant factor that causes variations in overland runoff and base flow in a basin, and because the topography and bedrock lithology of the basins are similar. The empirical equation may be used to estimate the combined overland runoff and local base flow for all basins in the study area. Estimates of net ground-water recharge or discharge in any Ozark basin having characteristics similar to those of the 100 reference basins can be made by comparing the measured total runoff of the basin to the empirically derived estimate of combined overland runoff and local base flow. A net ground-water discharge is indicated for basins where the measured total runoff is greater than the calculated overland flow plus local base flow (a component of regional base flow is present). A net ground-water recharge is indicated for basins where the measured total runoff is less than the calculated overland flow plus local base flow (potential base flow is lost through the permeable karst surficial aquifer).

\section{MODEL SIMULATION OF PREDEVELOPMENT GROUND-WATER FLOW}

A finite-difference digital model of ground-water flow in the Ozark Plateaus aquifer system was constructed and calibrated for steady-state, predevelopment conditions. The model was used to (1) study the 
hydrologic budget of the aquifer system, (2) estimate the relative transmissive properties of the aquifers and confining units, and (3) evaluate concepts regarding boundary conditions imposed upon the simulated aquifer system. Specific yield and storage coefficient were not estimated because the model simulates steady-state conditions.

A three-dimensional modular ground-water flow model developed by McDonald and Harbaugh (1984) was used. The model contains 616 grid cells, each representing a volume of porous material in which the hydraulic properties are assumed to be constant. The cells are arranged in an evenly spaced rectangular array consisting of 22 rows by 28 columns (fig. 57). The relatively large area represented by each grid cell $\left(195.3 \mathrm{mi}^{2}\right)$ dictates that the model only simulates regional aspects of the ground-water flow system. Cells are inactive where an aquifer is missing or not present. Potentiometric heads are not simulated at the inactive nodes. The axes of the grid network are oriented approximately northwest and northeast; their alignment is the same as that of the model grid used to simulate ground-water flow in the regional model of the Central Midwest area. These axes roughly coincide with the prevailing directions of fracture systems and faults (fig. 9), an alignment that facilitates the consideration of anisotropic hydraulic conductivity in the model.

The three-dimensional model contains four active layers that represent the following: (1) the Western Interior Plains confining system, (2) the Springfield Plateau aquifer, (3) the Ozark aquifer, and (4) the St. Francois aquifer. Potentiometric heads were simulated only for the three aquifers that are part of the Ozark Plateaus aquifer system. The intervening confining units (Ozark and St. Francois) were not simulated as active layers; instead, the hydraulic properties of these two confining units were used to calculate vertical leakage coefficients between the aquifers. The leakage coefficients were used in the model to simulate the vertical flow between the aquifers.

Transient simulations were not made because no long-term change in head or flow has been documented. Currently (1987) there is little regional drawdown in the three aquifers. Cones of depression associated with municipal pumping tend to be localized because ground-water withdrawals in most of the aquifers are small compared with the available quantity of water. Also, large-capacity wells are not concentrated in any one area. In addition, many of the large-capacity wells pump water from unconfined parts of the aquifers where storage properties and nearby recharge inhibit the development of large cones of depression.
A transient simulation of the Ozark Plateaus aquifer system probably would yield little additional information concerning the hydraulic properties or hydrologic relations of the aquifers in the system.

Large drawdowns have occurred in the tristate lead-zinc mining district located in the vicinity of the Missouri-Kansas-Oklahoma borders. In this area, large-capacity pumps were used to dewater the Springfield Plateau aquifer for mining activities during the early part of this century. The mining pumping, combined with municipal pumping by cities, lowered water levels several hundred feet throughout the mining district and surrounding area. However, many of the mines have been closed since World War II, and water levels have recovered their predevelopment altitudes, except where municipal pumping, most notably in Ottawa County, Oklahoma (fig. 3), is continuing. There are few records of waterlevel measurements during the period of intense pumping before 1930, and even fewer records of pumping rates are available. Drawdown created by mining and municipal pumping in the tristate district, although by far the largest in the Ozark Plateaus, was nevertheless a local condition relative to water levels in the remainder of the Ozark Plateaus aquifer system. Because of the magnitude of pumping in the tristate mining district and the close proximity of the district to the western boundary of the Ozark Plateaus aquifer system, it is probable that the effect of the pumping extended into the adjacent Western Interior Plains aquifer system.

In the mid-1960's, farmers in a three-county area of Missouri north of the tristate mining district began to pump water for irrigation. The irrigation wells and nearby municipal-supply wells caused ground-water levels to decline as much as $\mathbf{8 0}$ feet in some parts of the area (Kleeschulte and others, 1985). These wells, which are open to the confined part of the Springfield Plateau aquifer and Ozark aquifer, are adjacent to the salinewater-freshwater mixing zone. The effect of pumping from the irrigation wells probably also extends into the adjacent Western Interior Plains aquifer system.

\section{BOUNDARY CONDITIONS ON LATERAL GROUND-WATER FLOW}

Three types of boundary conditions were used in the model for simulation of ground-water flow in the Springfield Plateau aquifer, Ozark aquifer, and St. Francois aquifer. Each type was selected to best represent the ground-water flow conditions near the boundary of the aquifers. A brief description of these boundary conditions follows. 


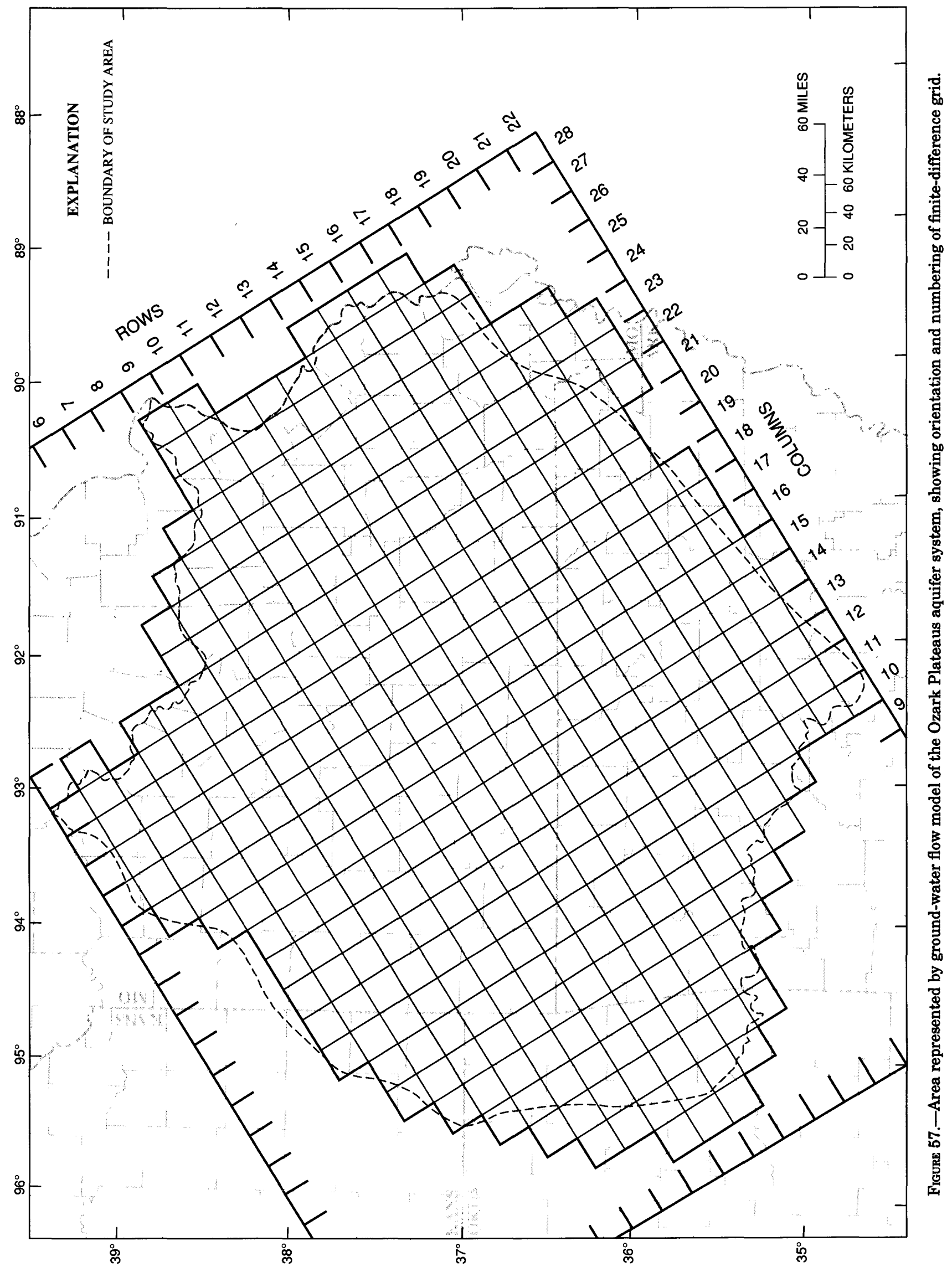


No-flow boundary: This boundary condition does not allow water to move beyond the limit of active nodes in the modeled area. It is inherent in the design of the model that unless an alternate boundary condition is specified at an active node adjacent to the inactive nodes, a no-flow boundary will be present. The most obvious location where this boundary can be appropriately used is at the interface of an aquifer and an impermeable barrier. The boundary condition is probably most often used to delineate a boundary that coincides with a stable ground-water divide or the axis of a potentiometric trough.

Specified-head boundary: The specified-head boundary condition is perhaps the simplest and most convenient to use in the active area of the model. It consists of assigning a fixed potentiometric head at a model node. The movement of ground water to or from a specified-head node depends upon the relative altitude of the potentiometric head at the specifiedhead node and the potentiometric heads at adjacent active nodes. This boundary condition commonly is used to simulate water moving to and from rivers or to and from the water table. To properly use the boundary condition to simulate the effect of a river on the aquifer, good hydraulic connection between the river and aquifer is necessary; that is, the river stage must be nearly identical with the water level in the aquifer cut by the river. If this condition is not met, it may be more appropriate to consider the presence of a hydraulic impedance between the aquifer and the river. Specified heads may be used in the outcrop area of an aquifer instead of using a specified recharge rate; however, this procedure eliminates the possibility of deriving information about the aquifer's hydraulic parameters in the outcrop area.

Specified-flux boundary: The specified-flux boundary condition is similar to the specified-head boundary condition except that the quantity of water per unit area moving to or from a node is specified directly instead of being calculated from the hydraulic gradient between nodes. Thus, water is always entering or exiting the cell at a fixed rate. Specified-flux boundaries can be used where ground water must enter or leave the area of active model cells at a known rate, such as where a surficial aquifer is recharged by precipitation.

The boundary conditions for each model layer are different. Because the Western Interior Plains confining system (layer 1) is not part of the Ozark Plateaus aquifer system and is not well represented in the study area, layer 1 is treated as a passive layer that simulates the vertical movement of water between the Ozark Plateaus aquifer system and land surface. Potentiometric heads are not simulated for layer 1.
The alternative would be to simulate layer 1 as an active layer, which would require estimates of specified flow or specified hydraulic gradient along the western and southern model boundary, and estimates of lateral hydraulic conductivity.

Model nodes that represent the Western Interior Plains confining system are assigned specified heads equal to the average hydraulic head of the weathered zone within each grid cell; they are designated by the letter " $\mathrm{S}$ " in figure 58. Local geohydrologic units, which are stratigraphically equivalent to the Western Interior Plains confining system and are located in the north-central part of the Salem Plateau, are not simulated because the units are small and consist of many isolated pieces rather than a single continuous unit. Local units along the eastern boundary of the modeled area are also represented by specified-head ("S") cells (fig. 58).

The area where the Springfield Plateau aquifer crops out (fig. 12) is simulated in layer 2 by specifiedflux recharge cells ("O" in figure 59). Specified heads ("S" in fig. 59) are assigned to cells in three areas: (1) where the Missouri River deeply incises the Springfield Plateau aquifer at the northern edge of the modeled area, (2) where the Mississippi River cuts into rocks stratigraphically equivalent to the aquifer near the northeastern boundary of the Ozarks, and (3) along the Neosho River in Oklahoma (fig. 6).

The boundary between the Springfield Plateau aquifer and the stratigraphically equivalent upper unit of the Western Interior Plains aquifer system west of the Ozarks is modeled as a no-flow boundary. In Arkansas, the Arkansas River alluvial valley is simulated as a no-flow boundary. The alluvial valley coincides with a major ground-water valley that separates ground-water flow in the Ozark area from flow originating south of the river.

A special condition is simulated where cells in layer 2 represent the part of the study area that is located within the Mississippi Alluvial Plain. In this area, the Springfield Plateau aquifer is not present, and the specified-head nodes in layer 2 represent the potentiometric heads in Cretaceous sand that overlies the Ozark aquifer. Because the Ozark confining unit is not present in this area, the vertical hydraulic gradient between layer 2 (Cretaceous sand) and layer 3 (Ozark aquifer) and leakage coefficients for the respective layers determine the rate at which ground water discharges upward from the Ozark Plateaus aquifer system. These cells are marked " $P$ " in figure 59.

The large outcrop area of the Ozark aquifer (fig. 12 ) is modeled in layer 3 by specified-flux recharge cells, designated " $O$ " in figure 60. Along the northern 


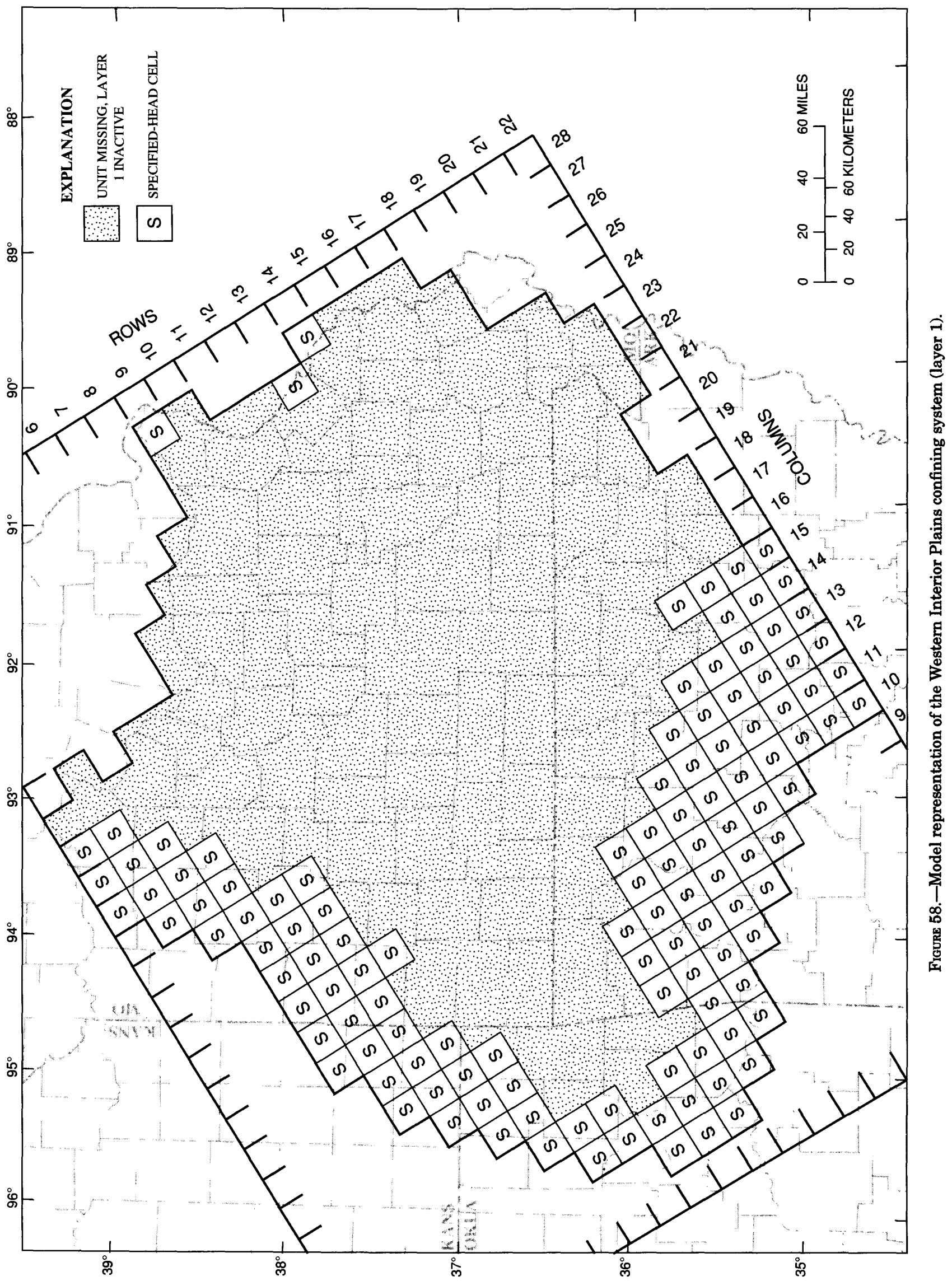




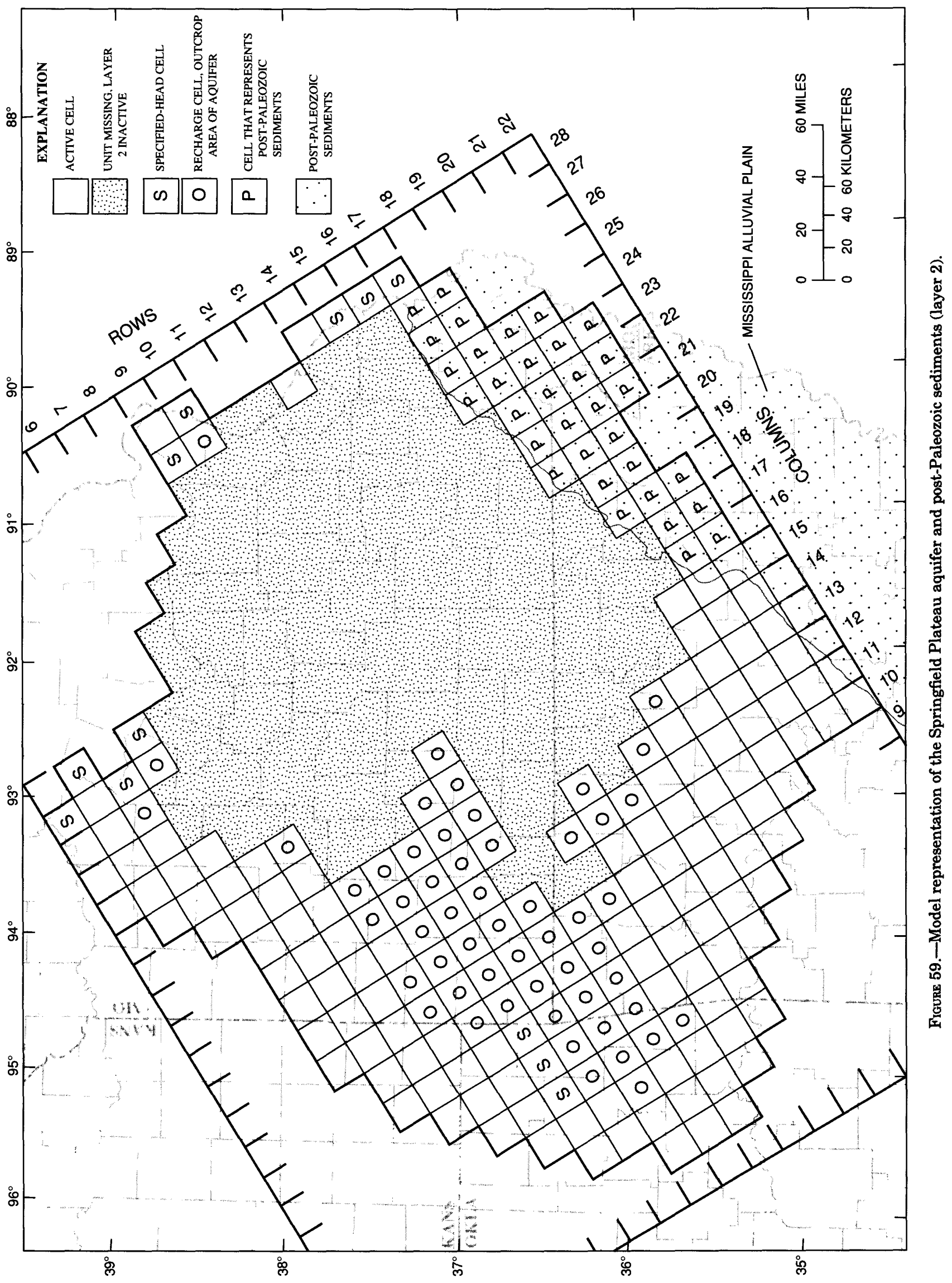




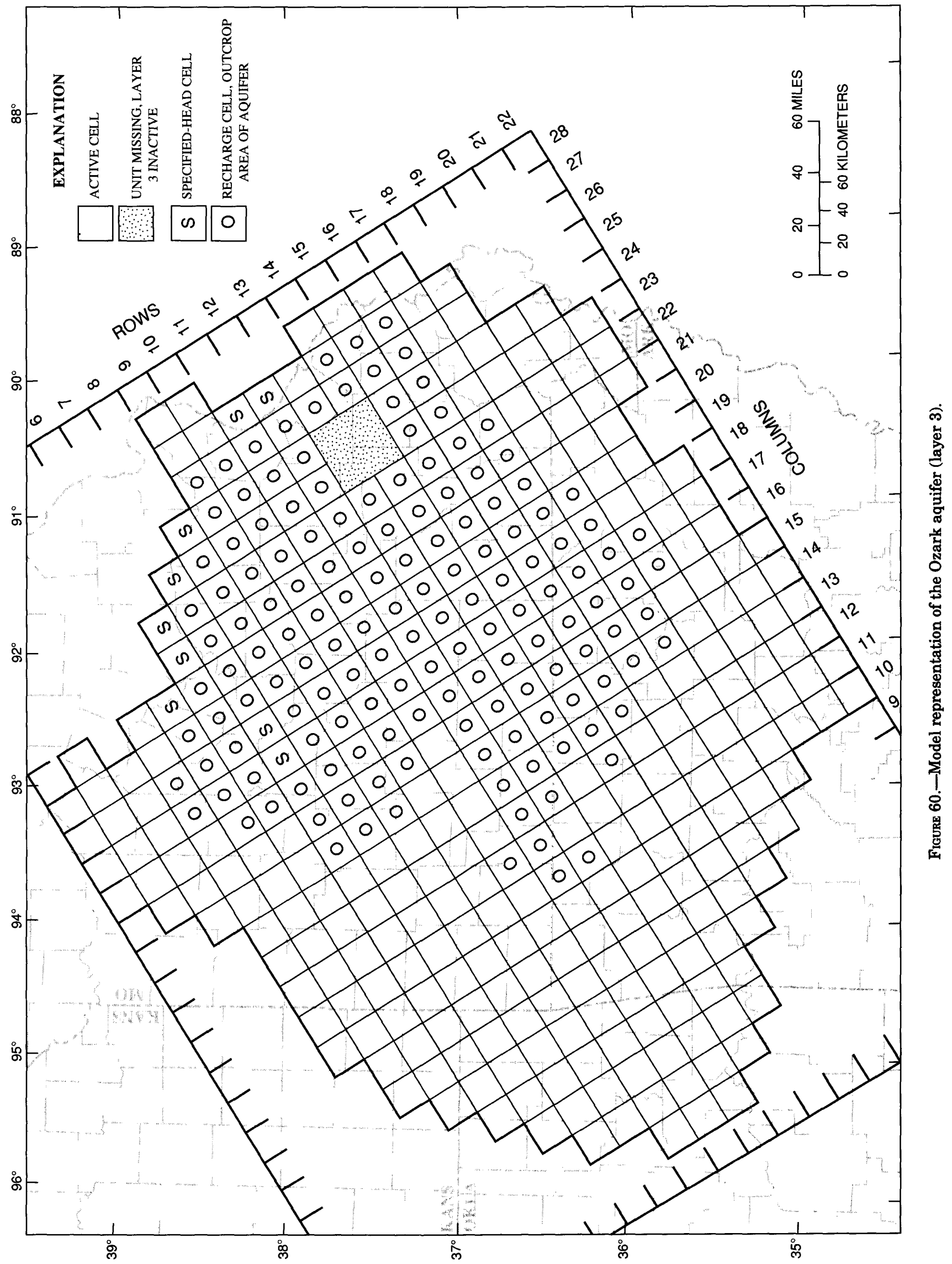


and eastern edge of the Salem Plateau where the Missouri and Mississippi River floodplains contact the aquifer, specified-head boundary cells ("S" in fig. 60 ) are assigned head values equal to the average stage of the rivers. A previous ground-water flow model for Cambrian and Ordovician rocks (equivalent to the Ozark aquifer) north of the Missouri River (Imes, 1985) showed that there was no advantage to simulating the interaction between the river and the aquifer using a streambed leakage coefficient and head differences between the river and aquifer. Two cells that represent part of the Osage River (fig. 6) are specified-head cells ("S" in fig. 60).

The salinewater-freshwater mixing zone in the west and southwest and part of the modeled boundary that parallels the Mississippi River to the east are treated as no-flow boundaries. Although some salinewater flows into the study area beneath the Marais des Cygnes, Osage, and South Grand Rivers, the quantity is believed to be small.

At the southern limit of the modeled area a no-flow boundary has been used to represent the trough in the potentiometric surface associated with the Arkansas River valley. A no-flow boundary has been placed along the southeast boundary of layer 3 at the approximate limit of freshwater in the Ozark aquifer.

The four cells that represent the outcrop area of the St. Francois aquifer (fig. 12) are represented in layer 4 by specified-flux recharge cells ("O" in fig. 61). These four cells also include outcrops of the Basement confining unit. At these locations the Basement confining unit is fractured and allows some lateral flow into the adjacent St. Francois aquifer. Thus, for modeling purposes the four cells contain permeable rock and receive recharge. Lateral boundary conditions in the lowermost St. Francois aquifer are difficult to determine because few data are available beyond the outcrop area. Because the Missouri and Mississippi River flood plains are believed to be discharge areas for water in the St. Francois aquifer, no-flow boundaries are placed along or in the vicinity of the Missouri and Mississippi Rivers (fig. 61). The limit of freshwater flow to the west in the St. Francois aquifer is assumed to coincide with that of the Ozark aquifer, and a no-flow boundary is assigned along the transition zone and the associated regional topographic low. In the south, for lack of data to prove otherwise, a no-flow boundary is assigned to the St. Francois aquifer at the same cells that are assigned as no-flow cells representing the Ozark aquifer (layer 3). Freshwater in the St. Francois aquifer probably discharges as it passes beneath the Ozark Escarpment and enters the Mississippi Embayment. A similar situation occurs along the eastern bound- ary where eastward-flowing ground water in the St. Francois aquifer discharges through overlying geohydrologic units into the Mississippi River valley. Therefore, no-flow boundaries for the St. Francois aquifer are appropriate along the southeastern and eastern boundary of the study area.

\section{BOUNDARY CONDITIONS AND LEAKAGE COEFFICIENTS GOVERNING VERTICAL GROUND-WATER FLOW}

The Basement confining unit is assigned a zero permeability at all nodes except the four cells that represent the St. Francois Mountains area; in these cells some water movement is allowed into the adjacent St. Francois aquifer. The Basement confining unit is treated as an impermeable barrier to the downward movement of water out of the Ozark Plateaus aquifer system. Ground-water movement through the Ozark and St. Francois confining units is assumed to be vertical. Neuman and Witherspoon $(1969$, p. 127) showed that where the hydraulic conductivity of a confining unit is considerably less than that of the adjacent aquifers, the direction of ground-water flow through the confining unit is nearly vertical and the rate of flow is proportional to the hydraulic gradient across the unit. This condition allows the use of a simplified flow equation to describe the volumetric leakage rate $\left(Q_{L}\right)$ through the confining unit:

$$
Q_{\mathrm{L}}=\left(K^{\prime} / b\right) A(\Delta H) \text { when } K^{\prime}<<K_{1} \text { and } K_{2},
$$

where

$Q_{\mathrm{L}}$ is the flow rate (in units of length cubed divided by time, or $\mathrm{L}^{3} \mathrm{~T}^{-1}$ ),

$K^{\prime}$ is the vertical hydraulic conductivity $\left(\mathrm{LT}^{-1}\right)$,

$b$ is the confining unit thickness $(\mathrm{L})$,

$A$ is the cross-sectional area of flow $\left(\mathrm{L}^{2}\right)$ or cell area,

$\Delta H$ is the difference in hydraulic head across the confining unit (L), and

$K_{1}, K_{2}$ are the hydraulic conductivities of the aquifers overlying and underlying the confining unit $\left(\mathrm{LT}^{-1}\right)$.

The hydrologic properties of the confining unit that determine the rate at which water leaks through the unit are expressed in the leakage coefficient $(L)$, where $L=K^{\prime} / b$. The vertical hydraulic conductivity $\left(K^{\prime}\right)$ is a function of several factors, including the presence of shale (usually a slightly permeable material), the rock's primary permeability, the presence of fractures, and postdepositional solution-enhanced permeability. 


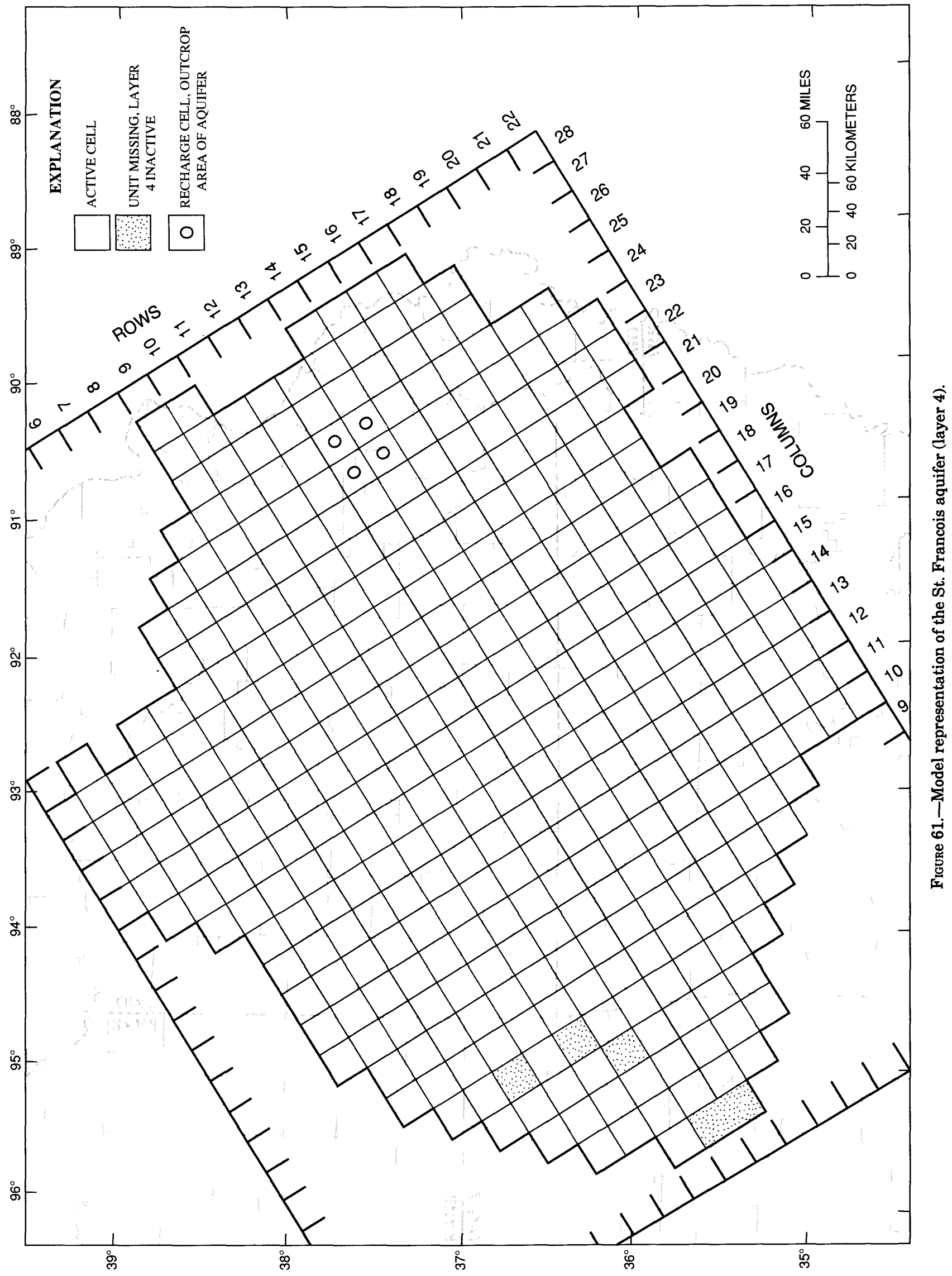


For this model, the effective leakage coefficient governing vertical flow between the centerlines of adjacent aquifers is calculated by the following equation:

$$
d / K=d_{1} / 2 K_{1}+d^{\prime} / K+d_{2} / 2 K_{2},
$$

where

$d / K$ is the effective inverse leakage coefficient between midpoints of the upper and lower aquifer ( $\mathrm{T}$ ),

$d_{1}, d^{\prime}, d_{2}$ are the thicknesses of the upper aquifer, confining unit, and lower aquifer, respectively (L), and

$K_{1}, K^{\prime}, K_{2}$ are the vertical hydraulic conductivites of the upper aquifer, confining unit, and lower aquifer, respectively $\left(\mathrm{LT}^{-1}\right)$.

A somewhat different situation exists between the uppermost two active model layers, those representing the Springfield Plateau aquifer and Western Interior Plains confining unit. There is no confining unit between the two layers. However, ground-water flow between water table in the near-surface weathered zone of the Western Interior Plains confining system and the underlying Springfield Plateau aquifer is impeded by the large quantity of slightly permeable material in the Western Interior Plains confining system. Therefore, a modified form of equation 3 was used to determine vertical leakage coefficients between the Western Interior Plains confining system and the Springfield Plateau aquifer:

$$
d / K=d_{1} / K_{1}+d_{2} / 2 K_{2},
$$

where

$d / K$ is the effective inverse leakage coefficient $(\mathrm{T})$,

$d_{1}, d_{2}$ are the thicknesses of the Western Interior Plains confining system and the Springfield Plateau aquifer, respectively (L), and

$K_{1}, K_{2}$ are the vertical hydraulic conductivites of the Western Interior Plains confining system and the Springfield Plateau aquifer, respectively $\left(\mathrm{LT}^{-1}\right)$.

Because almost the entire thickness of the Western Interior Plains confining system is effective in impeding the flow of ground water, the total thickness of the confining system is used in equation 4 .

\section{BOUNDARY CONDITIONS ASSOCIATED WITH RECHARGE AND DISCHARGE OF GROUND WATER}

Two physical processes pertaining to the interaction of ground water and surface water are important to the construction of the ground-water flow model for the Ozark Plateaus aquifer system: (1) infiltration of precipitation to the water table and (2) loss or gain of water from and to streams due to ground-water discharge or recharge. Because of the complexity of near-surface hydrologic processes in the Ozarks and the regional aspect of the ground-water flow model, it is not correct to simply assign a fraction of the mean annual precipitation as recharge to the water table during model cahibration. A large fraction of the infiltrated precipitation never enters the deeper, regional ground-water flow system, but moves rapidly through surficial aquifer material and discharges into streams within the same model cell the precipitation first entered.

A technique commonly used to simulate the loss (or gain) of ground water through leaky streambeds is to (1) specify combined geometric properties (stream length, average width, and streambed thickness) and hydraulic properties (average stream stage and streambed vertical hydraulic conductivity) for streams in a model cell as if they were a single stream and (2) calculate the quantity of water per unit time exchanged between the streams and aquifer $(Q)$ by the following equation.

$$
Q=\left(K^{\prime} / m\right)(w l)\left(H_{\mathrm{st}}-H_{\mathrm{aq}}\right)
$$

where

$K^{\prime}$ is the streambed vertical hydraulic conductivity $\left(\mathrm{LT}^{-1}\right)$,

$m$ is the streambed thickness (L),

$w$ is the average stream width (L),

$l$ is the stream length (L),

$H_{\text {st }}$ is the average stream stage (L), and

$H_{\mathrm{aq}}$ is the simulated hydraulic head in the aquifer cut by the stream (L).

It is not feasible to use this technique in this model of ground-water flow in the Ozark Plateaus aquifer system for several reasons. Stream stage and the actual potentiometric head of the aquifer can vary by hundreds of feet within a model-cell area. Streambed vertical hydraulic conductivity, thickness, and width can seldom be estimated to any degree of accuracy. There may be several large streams within one model cell with properties that cannot be combined as if they were a single stream. Also, the method assumes all flow is vertical through the streambed, an assumption that generally is not valid. Because of the many uncertainties, the commonly used method does not result in a well-defined simulation.

Because the Ozark Plateaus aquifer system flow model is a regional model and each model cell is large $\left(195.3 \mathrm{mi}^{2}\right)$, it is essential to determine the large quantity of ground water that cannot be accounted for by model simulation because it enters 
and exits the surficial aquifer within a single model cell. An alternative simulation method was developed to account for this ground water.

Consider a model cell that may contain one or more hydrologic features, such as ground-water divides, ephemeral or intermittent stream reaches, continuous stream reaches, losing stream reaches, springs, and spring catchment areas. In general, ground-water divides are parallel to surface-water divides with the possible exception of those divides in cells that contain losing streams, springs, and spring catchment areas. By observation of topography and surface-water drainage basins within each model cell, and with knowledge of the locations of losing stream reaches (from seepage run data) and spring catchment areas (from dye-trace analyses), it is possible to partition the total cell area $\left(A_{\mathrm{c}}\right)$ into two fractions (fig. 62). One fraction $\left(A_{\mathrm{i}} / A_{\mathrm{c}}\right)$ represents that part of the cell area in which precipitation that infiltrates to the water table appears (on the basis of analysis of two-dimensional potentiometric maps and topography) to flow to sinks (rivers, streams, or springs) within the same cell without crossing a cell boundary (intracell flow). It is important to note that some of the infiltrated precipitation (recharge) to area $A_{\mathrm{i}}$ is likely to flow across a cell boundary, especially a subjacent boundary, to sinks in other model cells. This possibility is shown by dashed flow lines in figure 63 (see cell $i, j+1$ ), a diagram of ground-water flow paths and their relation to model-cell boundaries. A second fraction $\left(A_{\mathrm{o}} / A_{\mathrm{c}}\right)$ represents that part of the cell area in which all the precipitation that infiltrates to the water table flows across a cell boundary to sinks in other model cells (intercell flow).

Intracell flow can be expressed as

$$
M\left(A_{\mathrm{i}} / A_{\mathrm{c}}\right) F_{\mathrm{u}}
$$

where $F_{\mathrm{u}}=A_{\mathrm{c}} f_{\mathrm{u}}$, and $f_{\mathrm{u}}$ is the specific recharge flux $\left(\mathrm{LT}^{-1}\right)$ to the water table for the cell area. $M$ is defined as a ratio of (a) the recharge to area $A_{i}$ that discharges to sinks within the cell before crossing the cell boundary to (b) the total recharge to area $A_{\mathrm{i}}$. The factor $M$ is not explicitly calculated, but is a model parameter determined during model calibration. Because most of the water that infiltrates to the water table in the vicinity of a gaining stream remains in the upper part of the surficial aquifer and discharges into the nearby stream, $M$ generally is less than but nearly equal to 1.0 for large-cell models that simulate flow in thick surficial aquifers. It typically varies from about 0.7 to 1.0 and expresses a relation between the volume of aquifer material represented by the model cell and the flow paths in the aquifer sys- tem. Generally, as the thickness of the represented aquifer decreases, the relative penetration depths of streams in the cell increase and the value of $M$ decreases. The decrease in $M$ implies that more water flows into the subjacent cell. Although values of $M$ may vary from one cell to another as the hydraulic properties of the aquifer vary, it is assumed that the variation is small and a single value of $M$ is appropriate for the entire modeled area.

Intercell flow has two components. The first component, recharge to area $A_{\mathrm{i}}$ that flows across a cell boundary (fig. 63), is generally small and can be expressed as

$$
(1-M)\left(A_{\mathrm{i}} / A_{\mathrm{c}}\right) F_{\mathrm{u}}
$$

The second component, flow originating in area $A_{0}$ (fig. 63), can be expressed as

$$
\left(A_{\mathrm{o}} / A_{\mathrm{c}}\right) F_{\mathrm{u}}
$$

The relative areas, $A_{\mathrm{i}}$ and $A_{0}$, were determined on a cell-by-cell basis using information on hydrologic and topographic features in each cell. Where seepage run measurements under low-flow conditions were not available to identify where streams change from ephemeral or intermittent to perennial flow, the flow conditions indicated by published hydrologic maps were used. The regional distribution of specific recharge flux $\left(f_{\mathrm{u}}\right)$ to the water table under predevelopment conditions was estimated from preagricultural ground-water recharge rates determined by Dugan and Peckenpaugh (1986).

The above discussion of intracell and intercell flow accounts for discharge to streams in a cell that originates as recharge within the cell. Now consider water that flows across cell boundaries and enters or leaves a cell through streambeds. This flow of water is designated $F_{\mathrm{s}}$ in figure 63 . Surface water can enter the aquifer system by percolation through the streambed of an ephemeral, intermittent, or losing stream (fig. 63, cell (i,j)). Ground water can discharge from the aquifer system by upward leakage through the streambed of a continuous, or gaining, stream (fig. 63, cell $(i, j+1)$ ). It was assumed during this study that intermittent streams generally recharge the underlying aquifers. They only receive groundwater discharge during relatively brief periods of higher water-table conditions.

If a cell contains only or mostly losing streams and the aquifer receives recharge from the streams, the sign of $F_{\mathrm{s}}$ is positive. If a cell contains one or more gaining streams and the aquifer discharges a net flow to the streams, the sign of $F_{\mathrm{s}}$ is negative. Only 
discharge that flows from an adjacent or subjacent cell is symbolized by $F_{\mathrm{s}}$. The net recharge and discharge at each cell that contributes to or results from intercellular flow $\left(F_{n c}\right)$ is calculated by the following equation:

$$
F_{\text {nc }}=\left(A_{\mathrm{o}} / A_{\mathrm{c}}\right) F_{\mathrm{u}}+(1-M)\left(A_{\mathrm{i}} / A_{\mathrm{c}}\right) F_{\mathrm{u}}+F_{\mathrm{s}}
$$

Note that on a regional upland area of a permeable aquifer one would expect to find predominantly intermittent streams. In this case, $F_{\mathrm{s}}$ will generally be small and positive (the aquifer will be recharged by the stream), $A_{\mathrm{i}}$ will be nearly zero, and $A_{\mathrm{o}}$ will approach 1 . Thus, $F_{\text {nc }} \approx F_{\text {u }}$, and cells representing this area will receive a large recharge flux. On the other hand, one would expect to find predominantly gaining streams in the regional lowlands. In this case, $F_{\mathrm{s}}$ will be negative (the aquifer will discharge to streams), $A_{0}$ will approach zero, and $A_{\mathrm{i}}$ will approach 1. Thus, $F_{\mathrm{nc}} \approx(1-M) F_{\mathrm{u}}-\left|F_{\mathrm{s}}\right|$, and because (1-M) generally is small, there will be a net loss (discharge) from the cell.

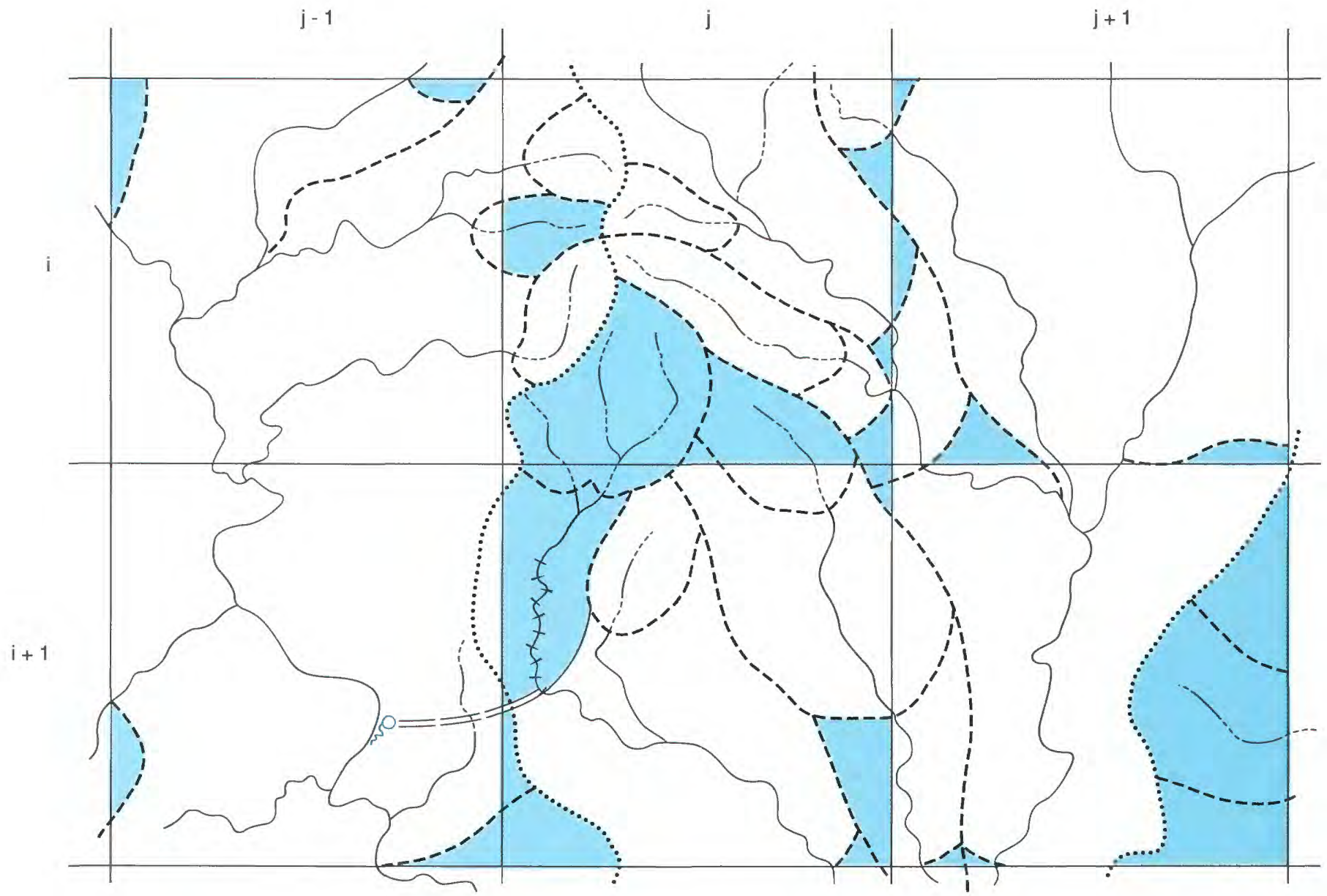

EXPLANATION
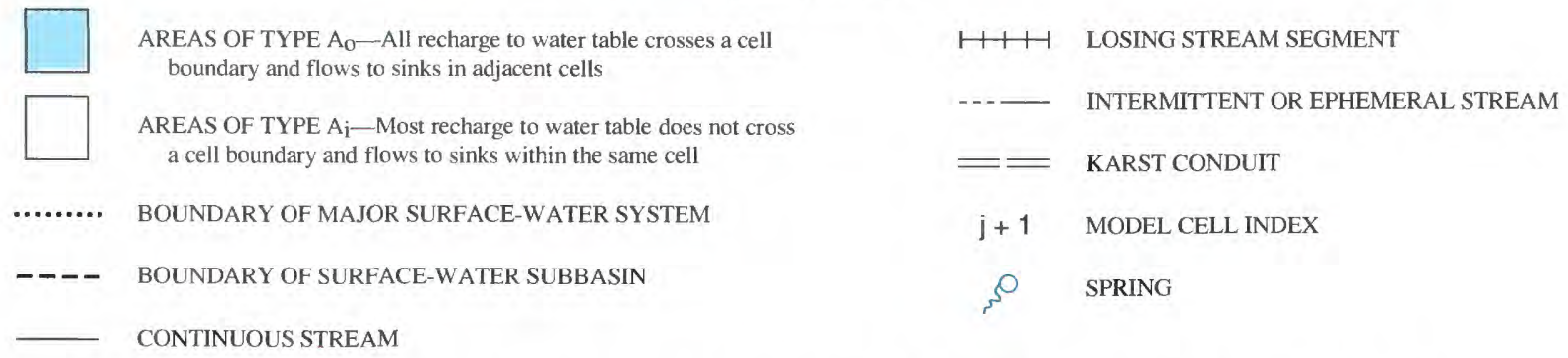

FigurE 62.-Plan view of hypothetical model cells showing areas of intracell and intercell ground-water flow. 
To estimate the quantity of $F_{\mathrm{s}}$ for small surfacewater basins in the Ozark area, we used the relation derived by Hedman (written commun., 1985) and presented in the section titled "Interaction of Surface and Ground Water: Recharge to the Regional Ground-Water Flow System." The following equations, which relate overland flow and local base flow $\left(Q_{0}+Q_{\text {lf }}\right)$ to precipitation, were used in conjunction with measured total runoff $\left(Q_{t}\right)$ to estimate the regional component of base flow $\left(Q_{\mathrm{rr}}\right)$ in small basins in the Ozark area:

$$
\begin{gathered}
Q_{\mathrm{rf}}=Q_{\mathrm{t}}-\left(Q_{\mathrm{o}}+Q_{\mathrm{lf}}\right) \\
=Q_{\mathrm{t}}-(0.924 P-27.1)\left(2.64 \times 10^{-9}\right) A_{\mathrm{b}},
\end{gathered}
$$

where

$Q_{\mathrm{rf}}$ is the regional component of base flow in the basin in cubic feet per second $\left(\mathrm{L}^{3} \mathrm{~T}^{-1}\right)$,

$Q_{\mathrm{t}}$ is the total runoff for the basin in cubic feet per second $\left(\mathrm{L}^{3} \mathrm{~T}^{-1}\right)$,

$Q_{0}$ is the overland flow component of total runoff in the basin in cubic feet per second $\left(\mathrm{L}^{3} \mathrm{~T}^{-1}\right)$,

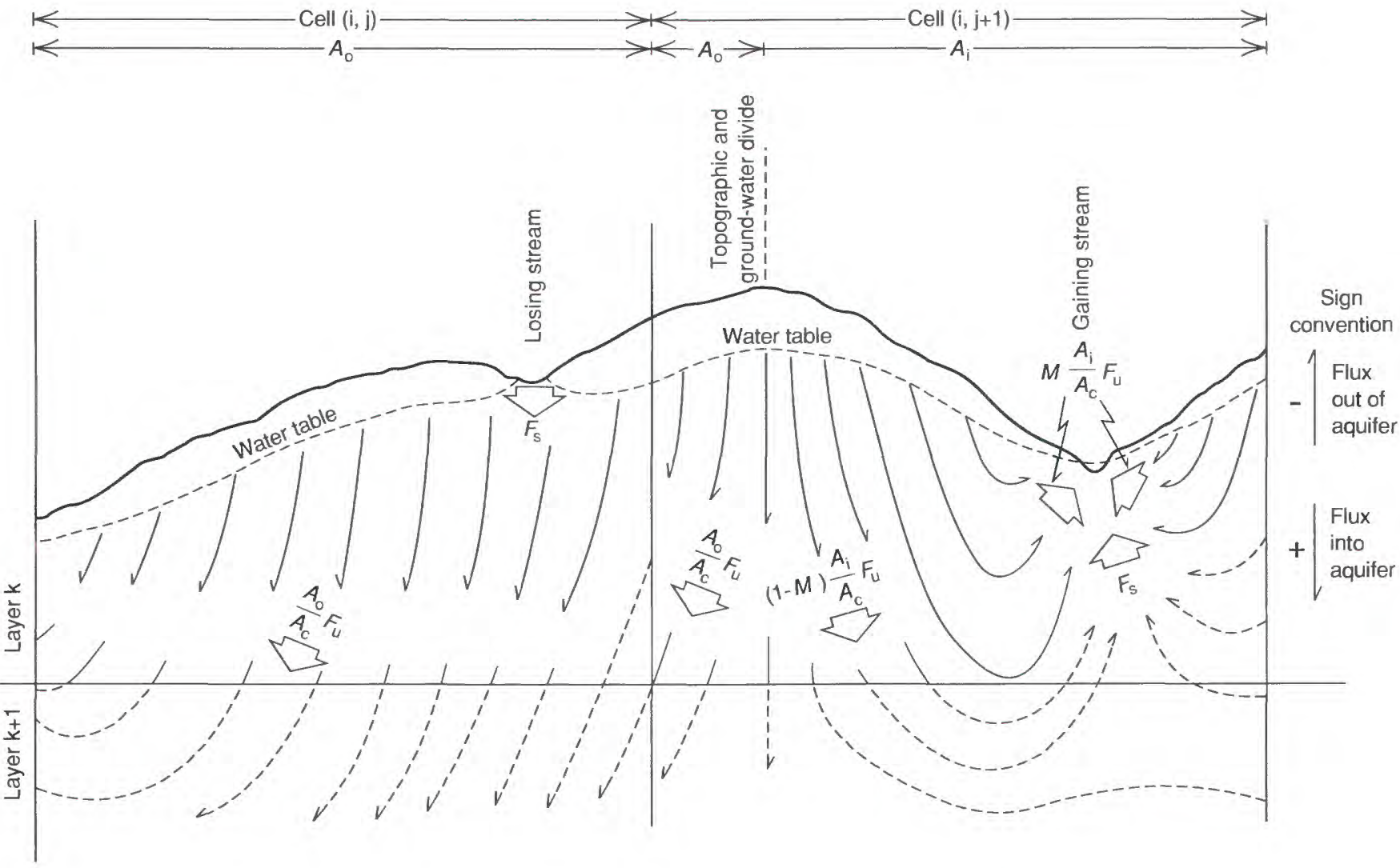

EXPLANATION

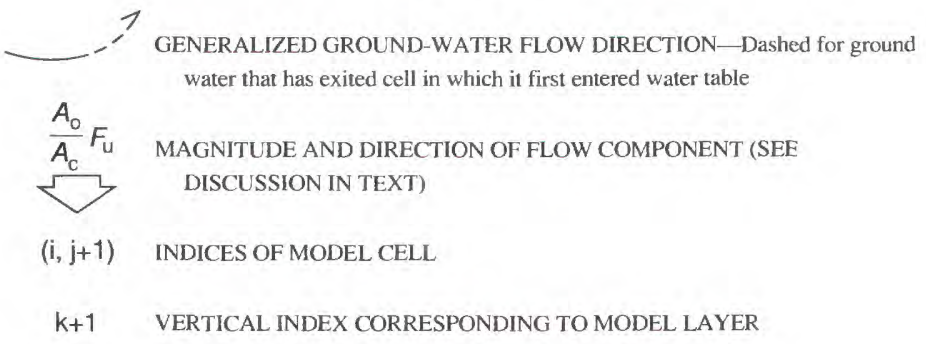

Figure 63.-Cross section of two hypothetical model cells showing recharge contributions to ground-water flow within model cells and between model cells. $A_{c}$, area of model cell; $A_{\mathrm{i}}$, area of cell in which precipitation entering water table appears to flow to sinks in same cell; $A_{0}$, area of cell in which precipitation enter- ing water table flows across cell boundary to sinks in other model cells; $F_{\mathrm{g}}$, water that flows across cell boundaries and enters or leaves a cell through streambeds; $F_{u}$, recharge to water table; $M$, recharge to area $A_{\mathrm{i}}$ that discharges to sinks within the cell divided by total recharge to area $A_{\mathrm{i}}$. 
$Q_{\text {lf }}$ is the local component of base flow in the basin in cubic feet per second $\left(\mathrm{L}^{3} \mathrm{~T}^{-1}\right)$,

$P$ is precipitation in inches per year $\left(\mathrm{LT}^{-1}\right)$, and

$A_{\mathrm{b}}$ is the basin area in feet squared $\left(\mathrm{L}^{2}\right)$, and $2.64 \times 10^{-9}$ is a conversion factor from inches per year to feet per second.

The above regression equation (equation 11) is approximately valid for all basins in the Ozark area. However, several small basins in the area, located primarily along the Missouri and Mississippi Rivers, have no measurements of total runoff. For these ungaged basins, the total runoff was estimated by a separate regression equation that relates total runoff to precipitation and was developed from gaged basins in the Ozark area (Hedman and others, 1987). The equation is

$$
Q_{\mathrm{t}}=(P-29.5)\left(2.64 \times 10^{-9}\right) A_{\mathrm{b}}
$$

The values of $Q_{\mathrm{rf}}$ for these ungaged basins can be estimated from equation 11 by substituting the value of $Q_{\mathrm{t}}$ from equation 12 into equation 11 . Regional base flow estimated from equation 11 is assumed to be equivalent or nearly equivalent to the values of $F_{\mathrm{s}}$. This assumption probably is valid for cells containing losing streams as well as those containing gaining streams, because equation 11 is a regional estimator of the combined flows. A deficiency in the estimated regional base flow indicates a regional ground-water flow into underlying aquifers in a basin, and an excess in the estimated regional base flow indicates a regional ground-water flow discharging from underlying aquifers into streams within a basin.

The net gain or loss of regional base flow in each basin was distributed to model cells in such a manner that a greater part of these gains or losses was assigned to the cells containing larger streams. Model cells containing streams were assigned one of three weighting codes $(\mathrm{A}, \mathrm{B}$, or $\mathrm{C})$ that were determined on the basis of relative stream sizes (fig. 64). Cells containing the largest streams were coded $\mathrm{A}$, cells containing intermediate-size streams were coded $\mathrm{B}$, and cells containing the smallest streams were coded $\mathrm{C}$. The distribution of estimated regional base flow $\left(Q_{\mathrm{rf}}\right)$ into each cell containing streams is determined by the following approach. For basins where cells contain the same weighting code (A, B, or $C)$, 100 percent of the estimated regional base flow is distributed among the coded cells according to the following equation:

$$
q_{\mathrm{rf}}(\mathrm{ij})=Q_{\mathrm{rf}}\left(\frac{a_{\mathrm{ij}}}{A}\right)
$$

where $q_{\mathrm{rf}}$ (ij) is the estimated regional base flow for coded cell $\mathrm{i}, \mathrm{j} ; a_{\mathrm{ij}}$ is the area of alluvial material along stream reaches or flood plains in the cell; and $A$ is the total area of alluvial material in all the coded cells. If two different weighting codes are assigned in a basin, then 75 percent of the regional base flow $\left(Q_{\mathrm{rf}}\right)$ is distributed into coded cells containing the larger streams and 25 percent into coded cells containing the smaller streams. If three different weighting codes are assigned in a basin, the distribution is made using 60 percent, 30 percent, and 10 percent of the regional base flow into coded cells containing the largest streams, intermediate streams, and smallest streams, respectively. This method of distributing recharge and discharge in each basin is logical, but should be considered an approximation of the actual distribution.

\section{MODEL CALIBRATION}

The steady-state ground-water flow model was calibrated to the predevelopment potentiometric surface of each of the three aquifers represented by model layers 2,3 , and 4 . Model calibration is a process whereby the difference between simulated hydraulic heads and flow volumes and measured hydraulic heads and flow volumes is minimized by adjusting and refining model variables that estimate hydraulic properties of the simulated flow system. A calibrated model may verify the accuracy of the conceptual model or indicate where the conceptual model does not adequately portray the actual flow system. Because of the large area of each model cell, hydraulic heads vary considerably within each cell, especially in areas where the aquifers crop out. Therefore, a measurement of head in a single well usually does not represent the average water level in the cell. For calibration, the average head for each model cell was estimated from predevelopment potentiometric-surface maps for each aquifer (Imes, 1990b, 1990d, 1990f). The maps generally contain considerable detail within the area represented by a cell. To obtain a representative head for each cell, the contour maps were digitized at the corners, center, and face centers of each cell, and the nine values were then averaged arithmetically.

The accuracy of the simulations was monitored during the calibration process by computing the average squared difference (error) between simulated potentiometric heads and averaged potentiometric heads obtained from the potentiometricsurface maps. The best simulations resulted in the smallest values of the average squared difference. 


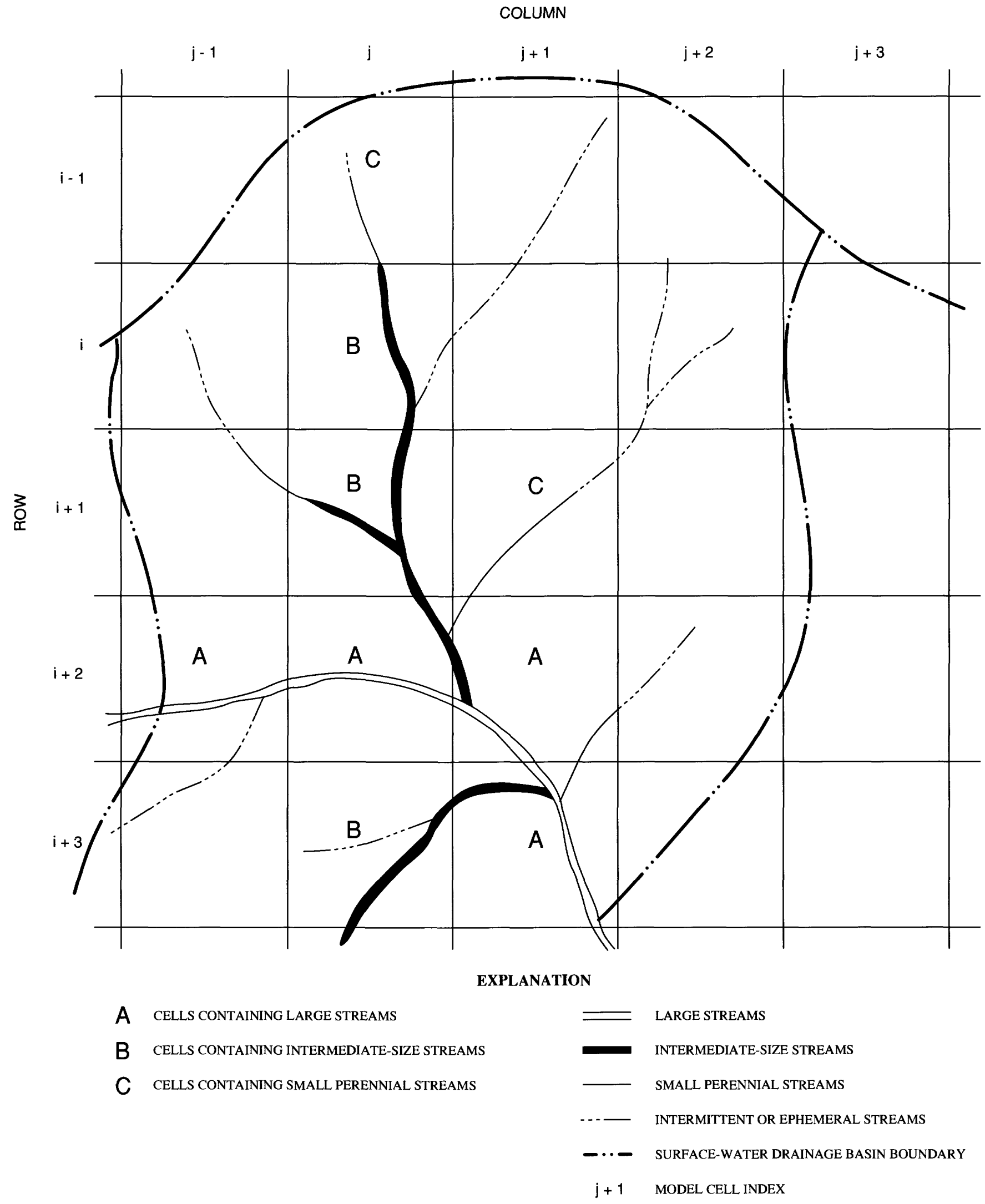

Figure 64.-Method of distributing regional base flow to model cells. 
The average positive difference and average negative difference between simulated and averaged potentiometric heads also were monitored to reduce the potential of a large bias in the head differences (that is, to ensure that the simulated heads were scattered fairly uniformly about the average heads). The accuracy of the simulation in a single layer can be improved slightly as hydrologic variables are changed, but sometimes improvement in one layer comes at the expense of accuracy of the simulation in other layers. It is not possible to closely calibrate simulated heads for all layers over the entire modeled area because averaged potentiometric-head data are not available for many cells. Head data for layer 2 (Springfield Plateau aquifer and post-Paleozoic sediments) are generally not available for northern Arkansas. More head data are available for layer 3 (Ozark aquifer) than for any other layer, but there are no data for parts of this layer south of the Boston Mountains. Sufficient data are available for layer 4 (St. Francois aquifer) to determine the representative water levels only in the immediate vicinity of the St. Francois Mountains.

Layer 2 was calibrated to the heads at 161 of 191 total active nodes. The average squared difference (error) between simulated and averaged heads is 1,590 feet squared (fig. 65), and the average absolute error is 27 feet. Specified-head nodes were placed at three locations (row 9, columns 5, 6, and 7) to more accurately simulate water levels in extreme southwestern Missouri and northeastern Oklahoma (fig. 59). The nodes are assigned water levels that approximate the stage of the Neosho River immediately downstream of the river's confluence with the Spring River (fig. 6); this reach includes a large reservoir, the Lake of the Cherokees. The specified-head nodes were considered because, in the initial simulations, not enough water discharged from the Springfield Plateau aquifer to the stream. Without the three specified-head boundary nodes, the net ground-water discharge to the stream at the nodes is 19 cubic feet per second; whereas with the specified heads present, the net discharge of ground water is 406 cubic feet per second.

A total of 286 nodes of a possible 380 active nodes were used to calibrate layer 3 . The average squared error of the simulated heads for layer 3 is 3,033 feet squared, somewhat greater than that for layer 2. The average absolute error is $\mathbf{4 1}$ feet. Specified-head nodes were added at two locations (row 7 , columns 17 and 18) in layer 3 (fig. 60). The nodes represent water levels in an extremely convoluted section of the Lake of the Ozarks (fig. 6) in the northwestern part of the study area. The effect of the specified-head nodes is to increase the amount of ground water discharging from the aquifer from 16 to 357 cubic feet per second and to generally reduce heads in the aquifer in the vicinity of the lake. The greatest errors in simulated heads for layer 3 are associated with cells (near row 12, column 11) that represent Table Rock Lake in southwestern Missouri (fig. 6). Simulated heads in the aquifer at five nodes near the lake are about 90 to 130 feet greater than the averaged heads. Specifiedhead nodes were not used to simulate Table Rock Lake, even though tests of the effect of placing a single specified-head node at row 12 , column 11, showed considerable improvement to three simulated heads in layer 3 in the immediate vicinity of the lake. This specified-head node was not used because it increased the error in simulated heads in layer 2 to the north of the lake. No combination of hydraulic properties was satisfactory in minimizing the errors in both layer 2 and layer 3 , although in general the simulations with the specified head were not greatly inferior to those without it.

The use of specified-head nodes to improve the quality of the simulation generally is not desirable. The three locations (one in layer 2 and two in layer 3 ) in which the simulated heads can be improved by the introduction of a few specified heads are all associated with large bodies of surface water. In each case, the effect of the specified heads is to simulate more ground water discharge from the aquifers to the streams than was simulated using estimated recharge to the water table. Recharge estimates yielded unrealistically low discharge values because the measurements on which the recharge estimates were based (mean annual runoff and stream baseflow measurements for the basins containing the large surface-water bodies) were obtained after the rivers were regulated. Regulation apparently has affected ground-water flow. For example, the estimated regional base flow for the White River downstream of Table Rock Lake (fig. 6) suggests that large quantities of ground water are discharging to the White River from the underlying aquifers, whereas the estimated flow at the lake suggests that the aquifer is being recharged in that area. Referring to the computation of mean annual runoff for the drainage basins, Hedman and others (1987) state, "For basins with major reservoirs, a common period of record was used. For basins with recently constructed reservoirs, the record before construction was used. For basins with old reservoirs, the period of record after regulation began was used, and adjustments were made for evaporation from 
the reservoirs." The three large surface-water bodies mentioned here (Lake of the Cherokees, Lake of the Ozarks, and Table Rock Lake) are older reservoirs. Consequently, the estimates of regional base flow probably are too small and are not indicative of the predevelopment conditions simulated by the model.

Simulated heads for layer 4 were calibrated at only 21 nodes out of 379 active nodes of the layer. The

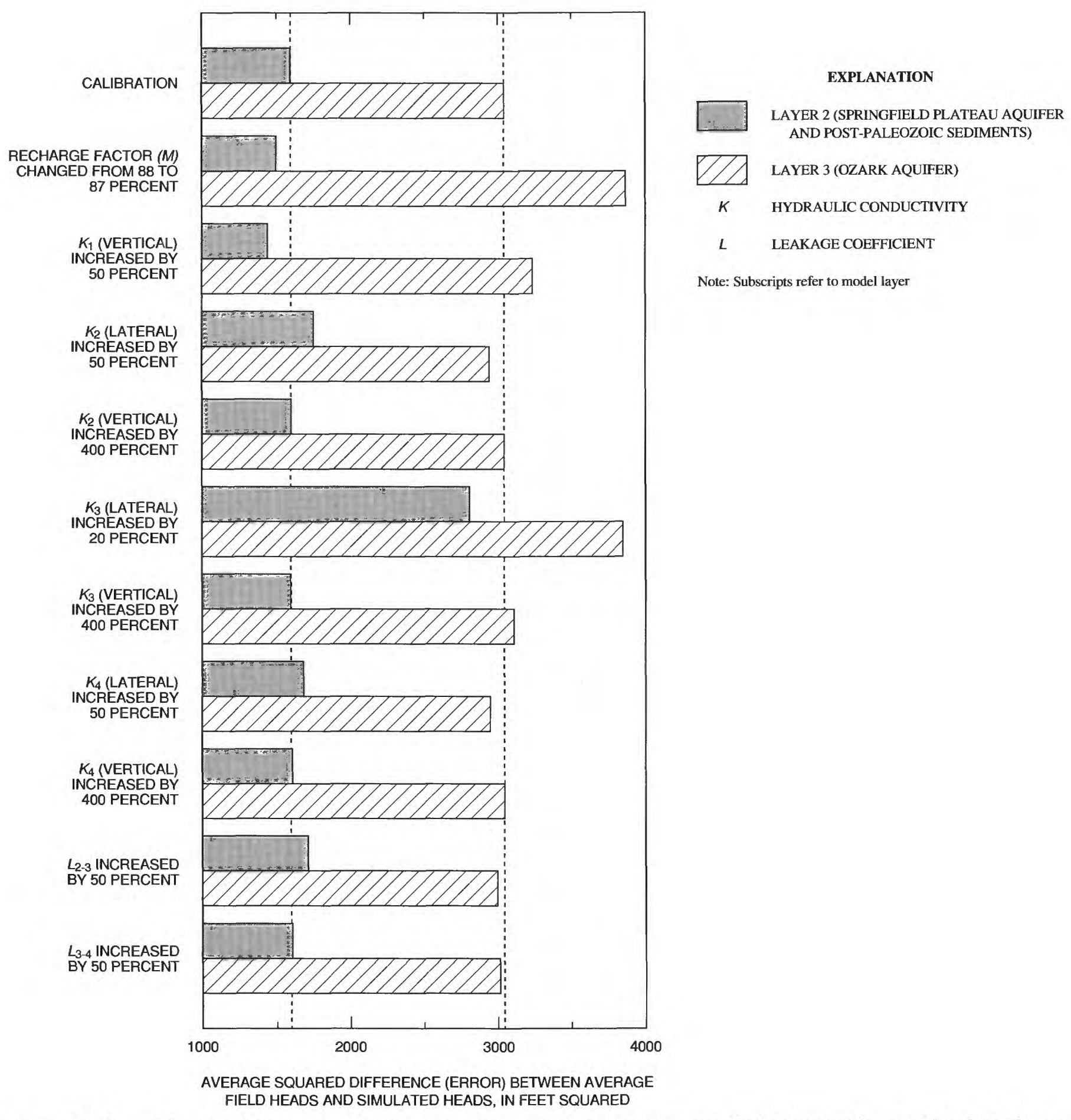

Figure 65.-Sensitivity of model layers 2 and 3 to selected changes in hydraulic properties. Dashed vertical lines mark values of errors for layers 2 and 3 generated during calibration of model; they are included to help readers compare those errors to errors produced by changing selected variables. 
average squared error, 12,760 feet squared, is the largest of the three simulated layers. The average absolute error between simulated and averaged heads, 84 feet, also is large. Differences in simulated and averaged heads for layer 4 have a positive bias. Because the aquifers represented by model layers 3 and 4 are both thin and hydrologically are closely linked near the St. Francois Mountains (in the area represented by the 21 calibration nodes), attempts to reduce the bias without adversely affecting simulated heads in layer 3 failed. Some of the difficulty in calibrating layer 4 may result from small springs that discharge at many locations near the southwest edge of the mountains.

The model generally is less sensitive to variables that control vertical leakage rates than to variables that control lateral flow, with the exception of the vertical hydraulic conductivity $\left(K_{1}\right)$, which controls the movement of ground water from layer 1 to layer 2. Small changes in the average squared errors for layers 2 and 3 occur when the ratios of lateral to vertical hydraulic conductivity for either layer are changed from 10 to 50 (a 400-percent increase). Thus the model is relatively insensitive to the ratio of lateral to vertical hydraulic conductivity of layers that represent the major aquifers. The model also is relatively insensitive to changes in the leakage coefficient arrays that represent the impedance of ground-water flow between layers 2 and 3 and between layers 3 and 4 by the intervening confining units (fig. 65). The model is slightly more sensitive to the leakage coefficients that link layers 2 and 3 than to the leakage coefficients that link layers 3 and 4 .

The model is most sensitive to changes in the vertical hydraulic conductivity of layer 1 , the lateral hydraulic conductivity of layer 3 , and recharge to cells representing outcrop areas (fig. 65). Because the model is steady-state and layer 3 crops out in most of the model area, the lateral hydraulic conductivity of layer 3 and the recharge factor $(M)$ are not independent variables. Thus, the model is equally sensitive to each of these two variables. Decreasing the recharge factor from the calibration value of 88 percent to 87 percent reduces the average squared difference for layer 2 from 1,590 to 1,481 feet squared, but it increases the average squared difference for layer 3 from 3,033 to 3,861 feet squared. The large increase in error for layer 3 suggests that the simulated heads in layer 3 are relatively sensitive to the recharge factor.

The effect of redistributing the recharge to the water table, as estimated by Dugan and Peckenpaugh (1986), to account for intracell flow is shown in figure 66. Before redistribution, the recharge to water table at each cell ranges from less than about 100 cubic feet per second in the northwest to more than 220 cubic feet per second in the southeast and reflects the effect of increasing precipitation to the southeast in the study area. After redistribution, the effective recharge per cell (the part that crosses cell boundaries) ranges from 12 to 100 percent of the estimated recharge to the water table. The distribution pattern is very complex as is shown in figure 66. Areas of greater recharge per cell roughly correspond to areas of greater elevation in the Ozark area. The two areas of greater recharge in south-central Missouri (Dent and Howell Counties, fig. 3) correspond to catchment areas of two first-order springs (average discharge greater than $100 \mathrm{ft}^{3} / \mathrm{s}$; fig. 55). It was noted that a significant simulation error would result from using a uniformly reduced (scaled) estimated recharge as opposed to using the redistributed recharge.

\section{MAGNITUDE AND DISTRIBUTION OF HYDRAULIC PROPERTIES DETERMINED BY MODEL SIMULATIONS}

The hydraulic conductivities and transmissivities determined by the calibrated model are regional values. The actual values may vary greatly over short distances within the aquifer. Because layer 1 (representing the Western Interior Plains confining system) is not part of the Ozarks Plateaus aquifer system, layer 1 was modeled as a specified-head layer. Therefore, no information on lateral hydraulic conductivity of the layer is derived from the model. The vertical hydraulic conductivity of the layer, however, is an important model variable that controls the amount of water flowing downward to the Ozark Plateaus aquifer system through the overlying Western Interior Plains confining system. The model distribution of vertical hydraulic conductivity for layer 1 (Western Interior Plains confining system) is shown in figure 67. Only two values $\left(1.0 \times 10^{-7}\right.$ and $\left.2.0 \times 10^{-8} \mathrm{ft} / \mathrm{s}\right)$ are assigned to the nodes. The larger values are assigned to areas where the Western Interior Plains confining system is thinner and contains a larger fraction of more permeable sandstone and limestone. The leakage coefficient of layer 1 generally decreases to the west and south where the confining system becomes thicker (fig. 67).

The lateral hydraulic conductivity of nodes in layer 2 , representing the Springfield Plateau aquifer, is constant at 0.00025 foot per second (fig. 68), and the ratio of lateral to vertical hydraulic conductivity for the aquifer is 10. It is probable that the actual hydraulic conductivity in the Arkansas River Valley, where the aquifer is deeply buried, is less than the value derived from simulation. Because no field head data can be 


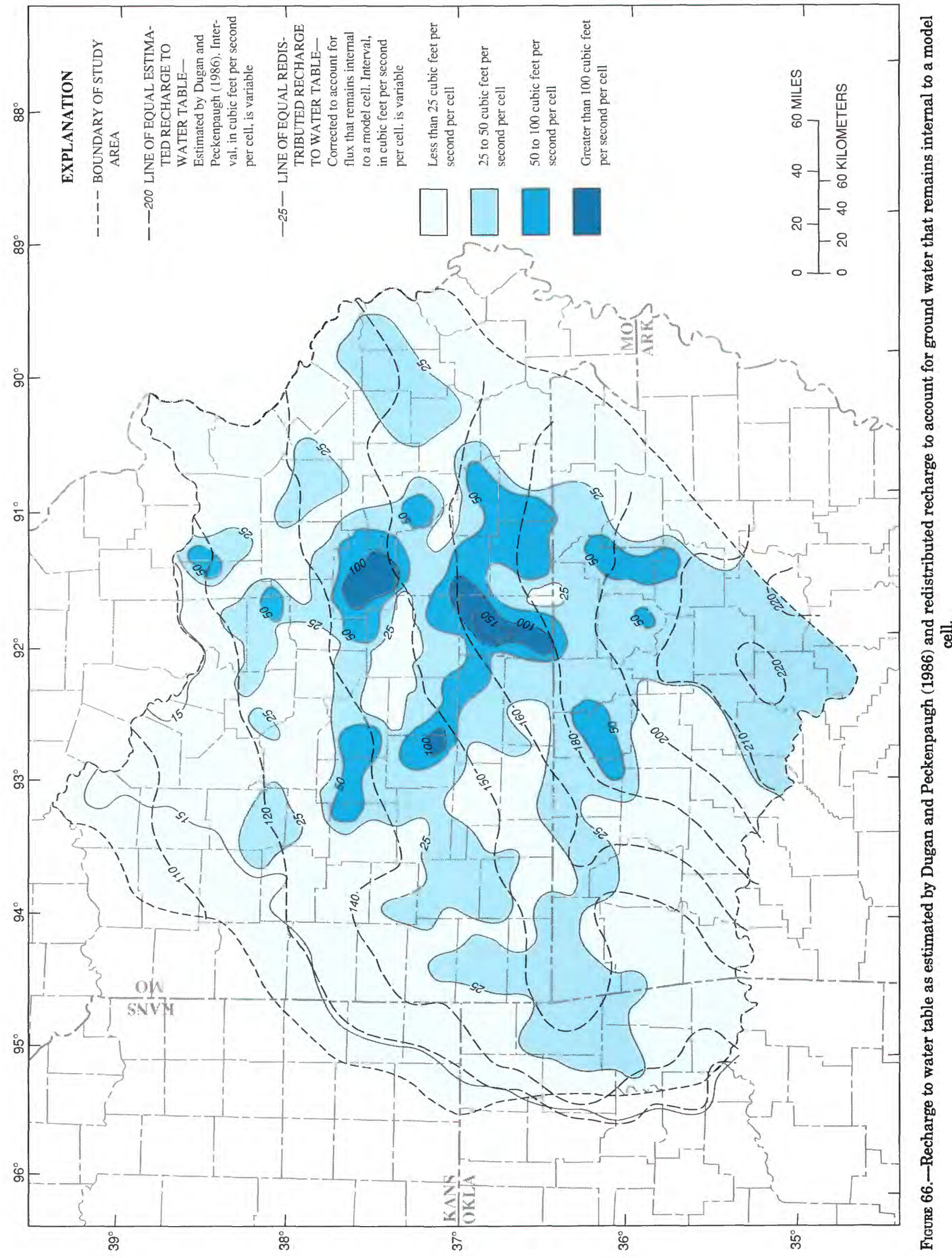




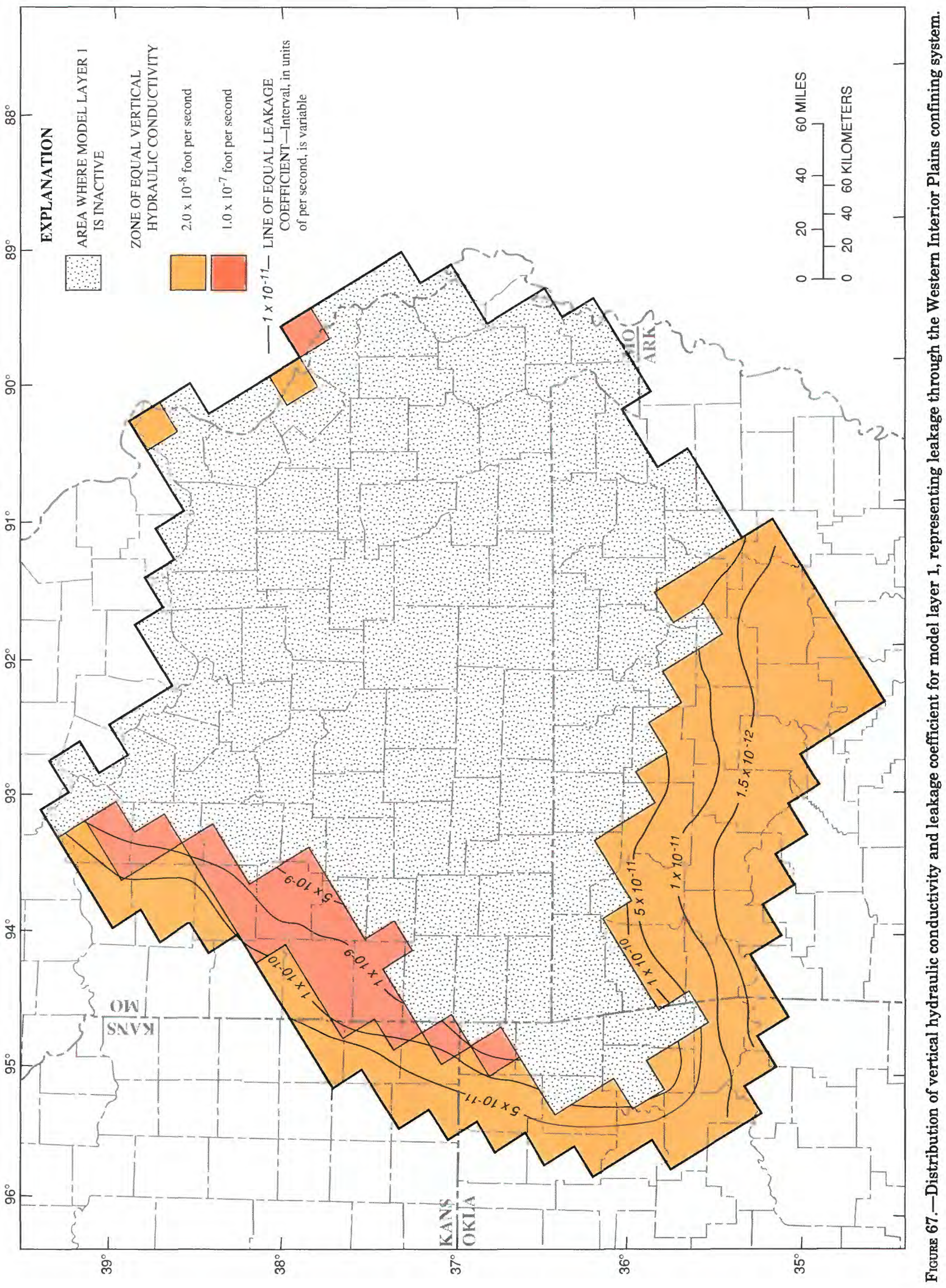




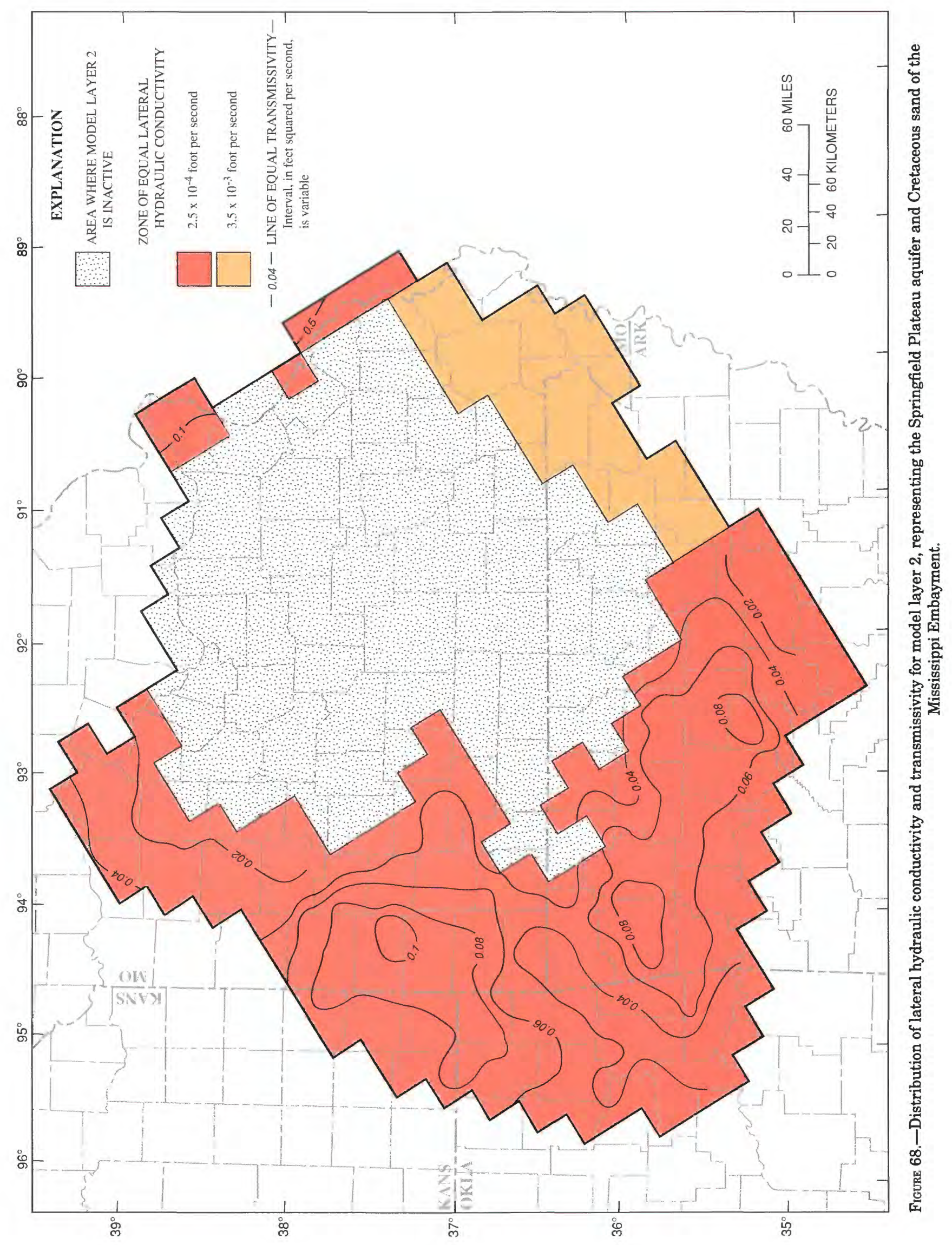


used to compare with the simulated heads in this area, the lateral hydraulic conductivity used for calibration in this area may be incorrect. The transmissivity of the Springfield Plateau aquifer ranges from 0.02 foot squared per second in the northwest and southeast to about 0.1 foot squared per second at three locations in the west, southwest, and south, where the aquifer is thicker (fig. 68). The lateral hydraulic conductivity, where layer 2 represents Cretaceous sands of the Mississippi Embayment (fig. 68), is 0.0035 foot per second (T.O. Mesko, U.S. Geological Survey, written commun., 1985). However, because nodes in this part of layer 2 are assigned specifiedhead values equal to the potentiometric heads in the Cretaceous sediments and because the thickness of the layer is arbitrarily set at 0.0001 foot, the lateral hydraulic conductivity of the Cretaceous sediments given by Mesko cannot be checked by the model.

The model-calibrated vertical hydraulic conductivity between the middle of the Springfield Plateau and the Ozark aquifer ranges from $1.0 \times 10^{-8}$ foot per second at nodes where the Ozark confining unit is 100 percent shale, to $5.0 \times 10^{-8}$ foot per second at nodes where the Ozark confining unit contains no shale (fig. 35). Between these two extremes, the conductivity is linearly scaled among the nodes according to the percentageof-shale content of the Ozark confining unit (fig. 69). Generally, the calibrated conductivity is smaller in the southwestern part of the study area and increases to the northeast. The leakage coefficient generally is larger (more than $2.0 \times 10^{-9}$ per second) in southwestern Missouri and southeastern Kansas where the Ozark confining unit is thinner, whereas the leakage coefficient is smaller (less than $2.0 \times 10^{-10}$ per second) in the south where the Ozark confining unit is thicker. Because the Ozark confining unit is not present beneath the Mississippi Alluvial Plain, the leakage coefficient between the Cretaceous sands and Ozark aquifer is large, ranging from about $2.5 \times 10^{-9}$ to about $1.0 \times 10^{-8}$ per second.

The lateral hydraulic conductivity of layer 3 , representing the Ozark aquifer, ranges from about $1.0 \times 10^{-5}$ foot per second near the southern and southeastern boundaries of the study area where the aquifer is deeply buried to about $8.0 \times 10^{-4}$ foot per second in the Salem Plateau where deep karst features conduct ground water to discharge to streams and large springs (fig. 70). Lateral hydraulic conductivity of the aquifer along the western edge of the modeled area ranges from about $6.0 \times 10^{-4}$ foot per second to about $7.0 \times 10^{-4}$ foot per second. Values of lateral hydraulic conductivity for layer 3 are in general agreement with hydraulic conductivity estimates (fig. 27) derived from specific-capacity data. A constant ratio of lateral to vertical hydraulic conductivity of 10 was used for layer 3 for the entire model. The transmissivity of the aquifer is largest along the White River valley (fig. 6) where the hydraulic conductivity of the aquifer is large and the thickness of the aquifer begins to increase to the south (fig. 70). The transmissivity decreases abruptly to the extreme south and southeast because the conductivity of the aquifer decreases more abruptly than its thickness increases.

The simulated vertical hydraulic conductivity between the middle of the Ozark and St. Francois aquifers is constant throughout the modeled area at $1.0 \times 10^{-8}$ foot per second (fig. 71 ). The vertical hydraulic conductivity was not scaled by the percentage-ofshale content of the St. Francois confining unit because percentage-of-shale data are not available for the entire modeled area and because the model is relatively insensitive to this variable. The leakage coefficient is largest at two locations in the west and northwest where it exceeds $2.0 \times 10^{-10}$ per second (fig. 71). The leakage coefficient decreases to less than $4.0 \times 10^{-11}$ per second in much of the eastern and southern part of the model except near the St. Francois Mountains and in the extreme southeast, where it is greater than $1.0 \times 10^{-10}$ per second.

Layer 4, representing the St. Francois aquifer, was assigned a lateral hydraulic conductivity of $1.6 \times 10^{-4}$ foot per second in the area around the St. Francois Mountains where the aquifer is exposed or not deeply buried, and $8.0 \times 10^{-5}$ foot per second elsewhere in the model (fig. 72). The transmissivity of the aquifer is greater than $\mathbf{0 . 1}$ foot squared per second near the St. Francois Mountains and generally decreases uniformly to less than 0.0025 foot squared per second at the western edge of the model (fig. 72).

\section{REGIONAL GROUND-WATER BUDGET}

The regional ground-water budget determined by simulation data is presented here in conjunction with the estimates of recharge to the water table by Dugan and Peckenpaugh (1986) and the investigation of surface-water and ground-water relations discussed by Hedman and others (1987). A diagrammatic regional ground-water budget as derived from the model (fig. 73) shows net flow between model layers and to rivers and lakes modeled as specified-head boundaries. One flow quantity of special interest is the net flow of 867 cubic feet per second from layer 3 to nodes in layer 2 that represent Cretaceous sands. This discharge corresponds to the net flow of groundwater out of the Ozark Plateaus province into the Mississippi Embayment. 


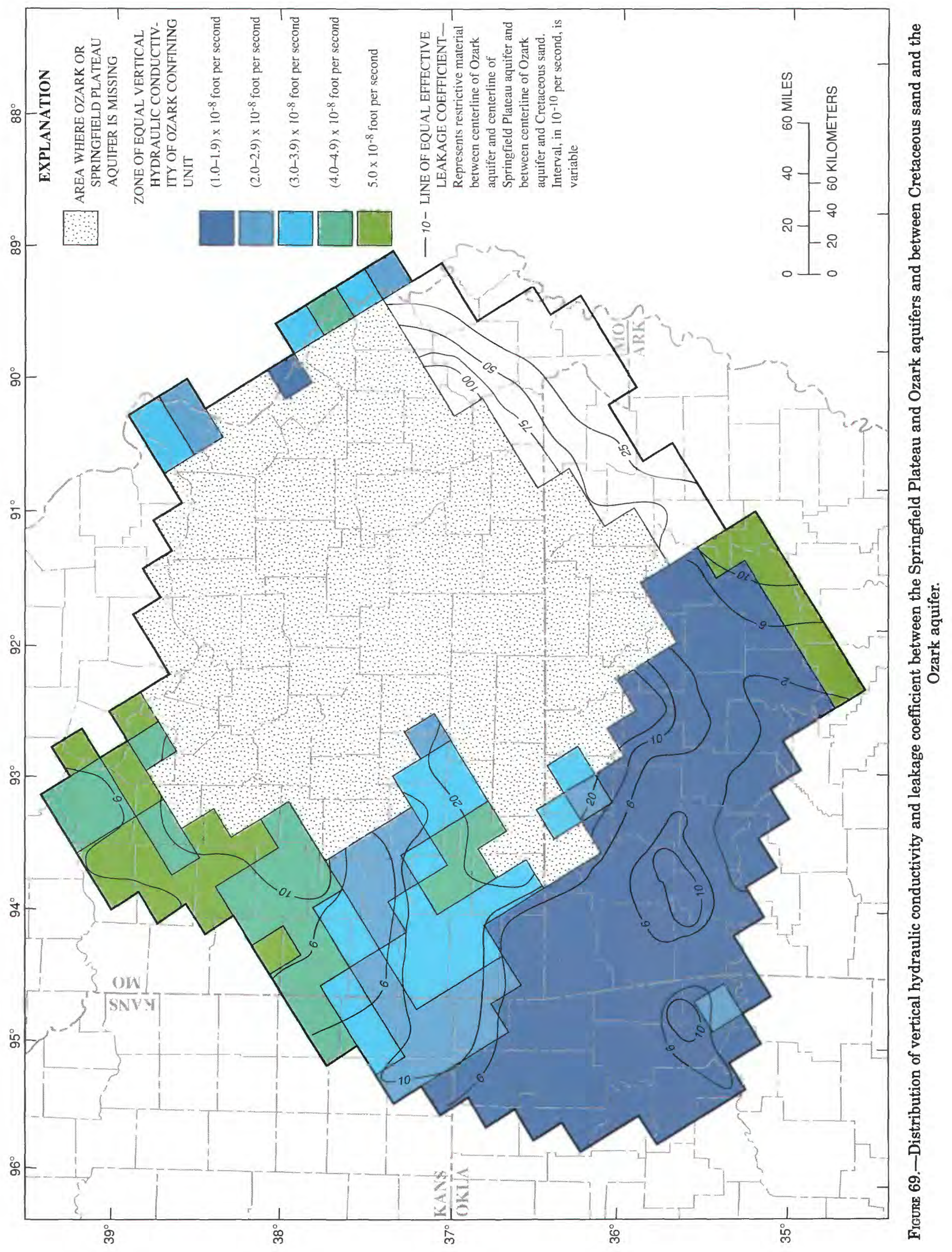




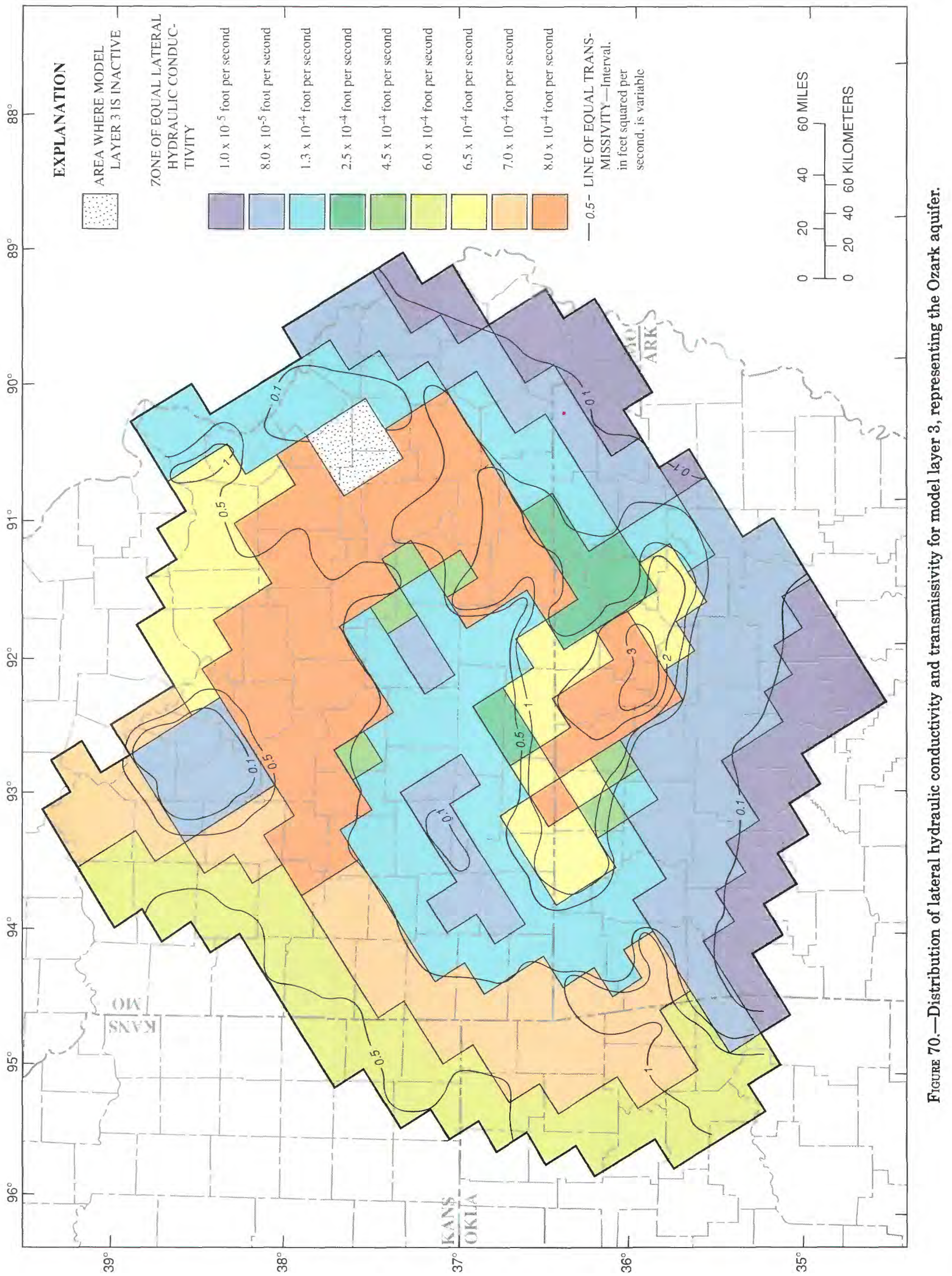




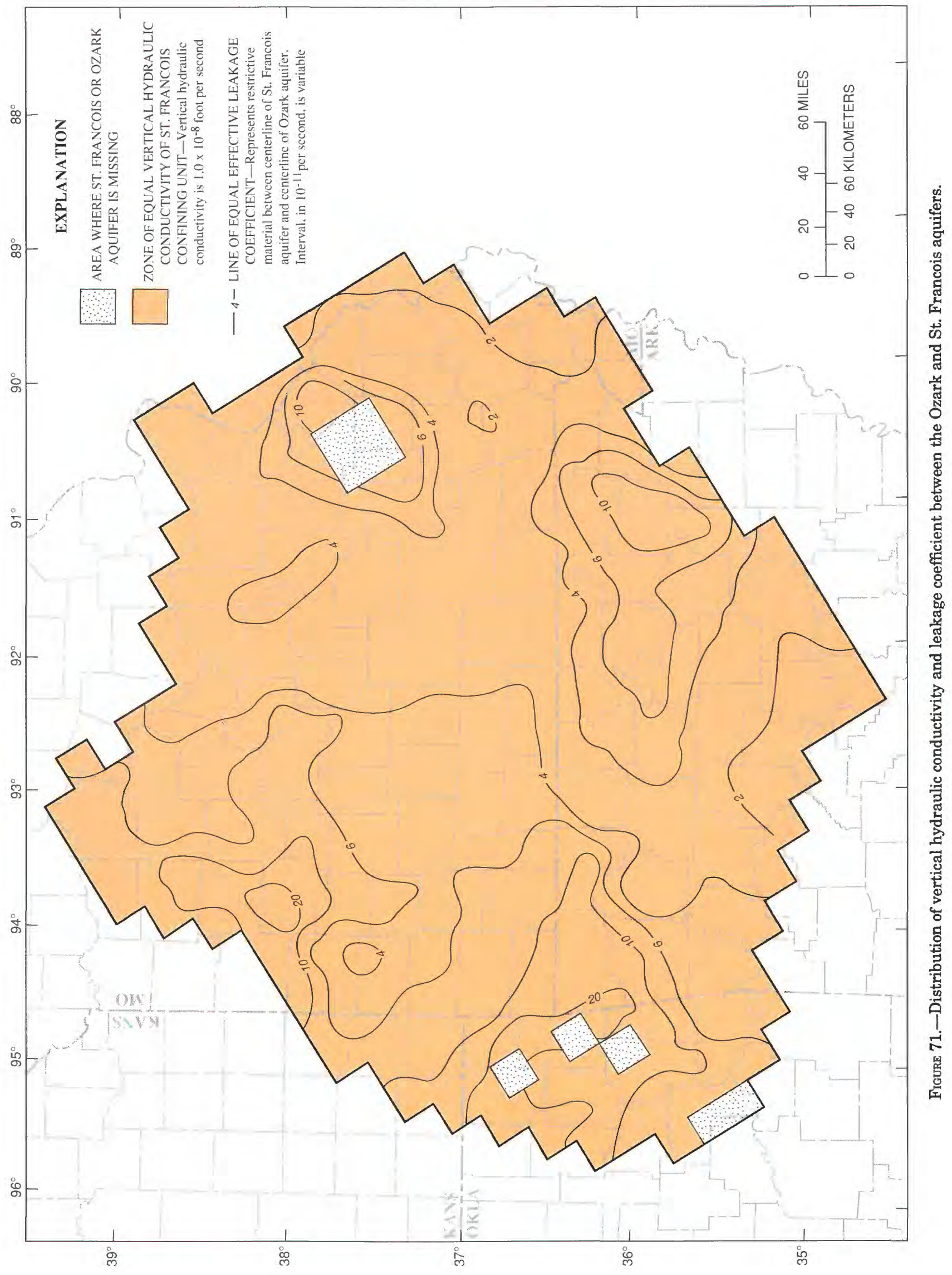




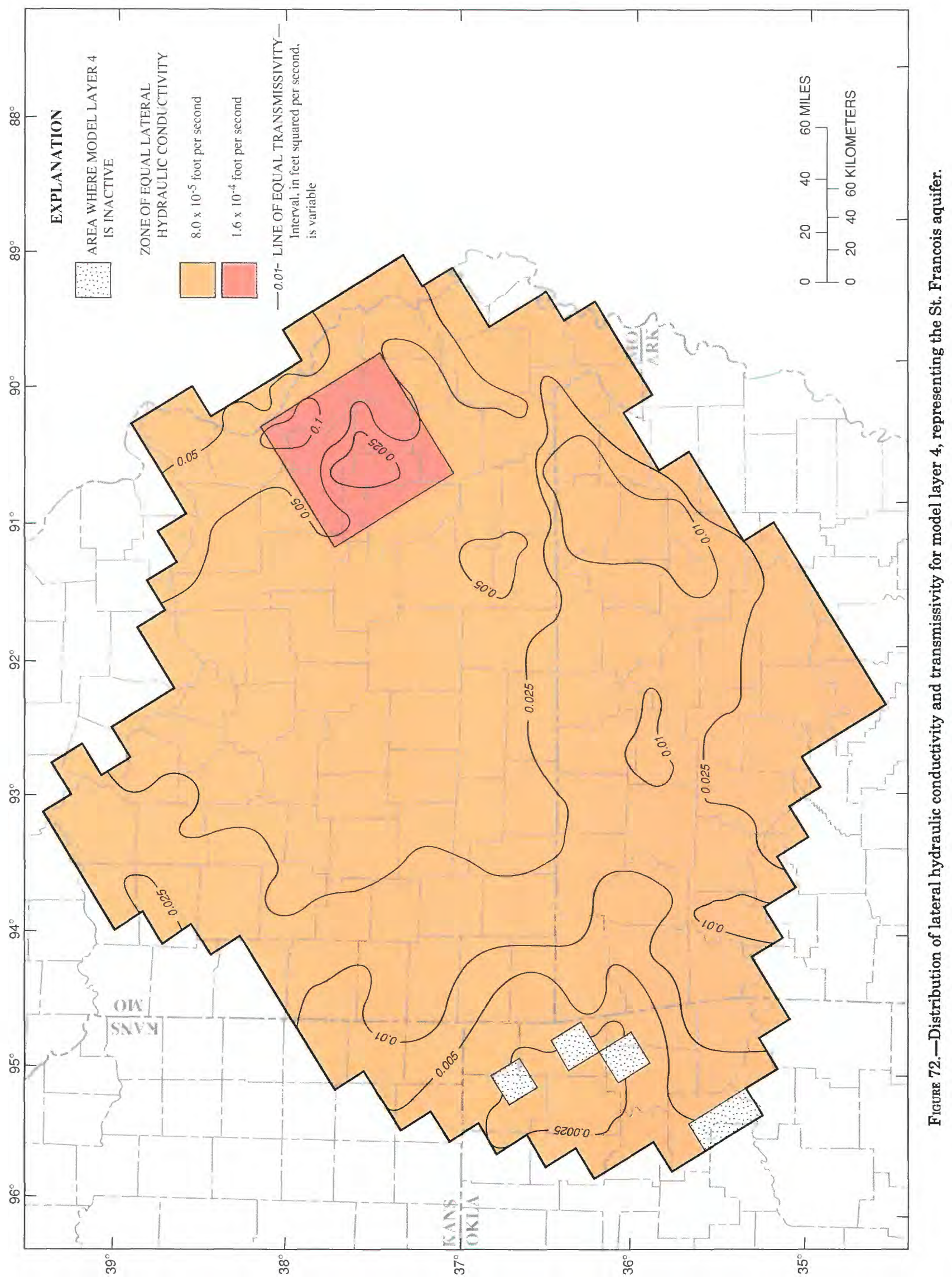


It must be emphasized that the water budget presented in figure 73 is a model water budget that represents only the components of regional, predevelopment ground-water flow in the three aquifers. The model water budget is an approximate water budget because (1) the model does not simulate the cells modeled as specified heads, and (2) the model does not simulate recharge within a cell, only the redistributed recharge for intercell flow. The relation between the simulated regional-flow water budget and the water budget derived from estimates of recharge to the water table and surface-water and ground-water interaction is shown in table 3. For example, of the 127,187-cubicfeet-per-second mean annual precipitation that falls on the outcrop area of the Ozark Plateaus aquifer system, 95,513 cubic feet per second, or 75 percent, is removed as evapotranspiration and overland flow to streams. Only 25 percent, or 31,667 cubic feet per second, of the mean annual precipitation recharges the aquifer system. Because of the large size of model cells in the regional model, 24,577 cubic feet per second of the water recharging the aquifer system discharges to sinks within the same cell receiving the recharge and cannot be simulated by the model. Thus, 19 percent of the precipitation (or 78 percent of the total recharge) is unsimulated flow. Only 6 percent of the precipitation (or 22 percent of the total recharge) contributes to the simulated deeper flow $\left(7,091 \mathrm{ft}^{3} / \mathrm{s}\right)$. Of this deeper intercell flow, 4,035 cubic feet per second discharges to streams and springs inside the study area, and 3,056 cubic feet per second discharges as boundary flow to the Missouri, Neosho, Mississippi, and Arkansas Rivers (fig. 6), aquifers in the Mississippi Embayment, and the water table in the overlying Western Interior Plains confining system. Because of the small pumpage from wells (about $320 \mathrm{ft}^{3} / \mathrm{s}$ in 1970-1979) in comparison to the large natural flow, the predevelopment regional ground-water budget of the Ozark Plateaus aquifer system is probably similar to the present-day regional budget.

The amount of drainable water in the Ozark Plateaus aquifer system is a function of specific yield or storage coefficient and thickness of the water-yielding units. The estimated specific yields for the St. Francois, Ozark, and Springfield Plateau aquifers in the freshwater portion of the flow system are 0.05, 0.10,

\section{EXPLANATION}
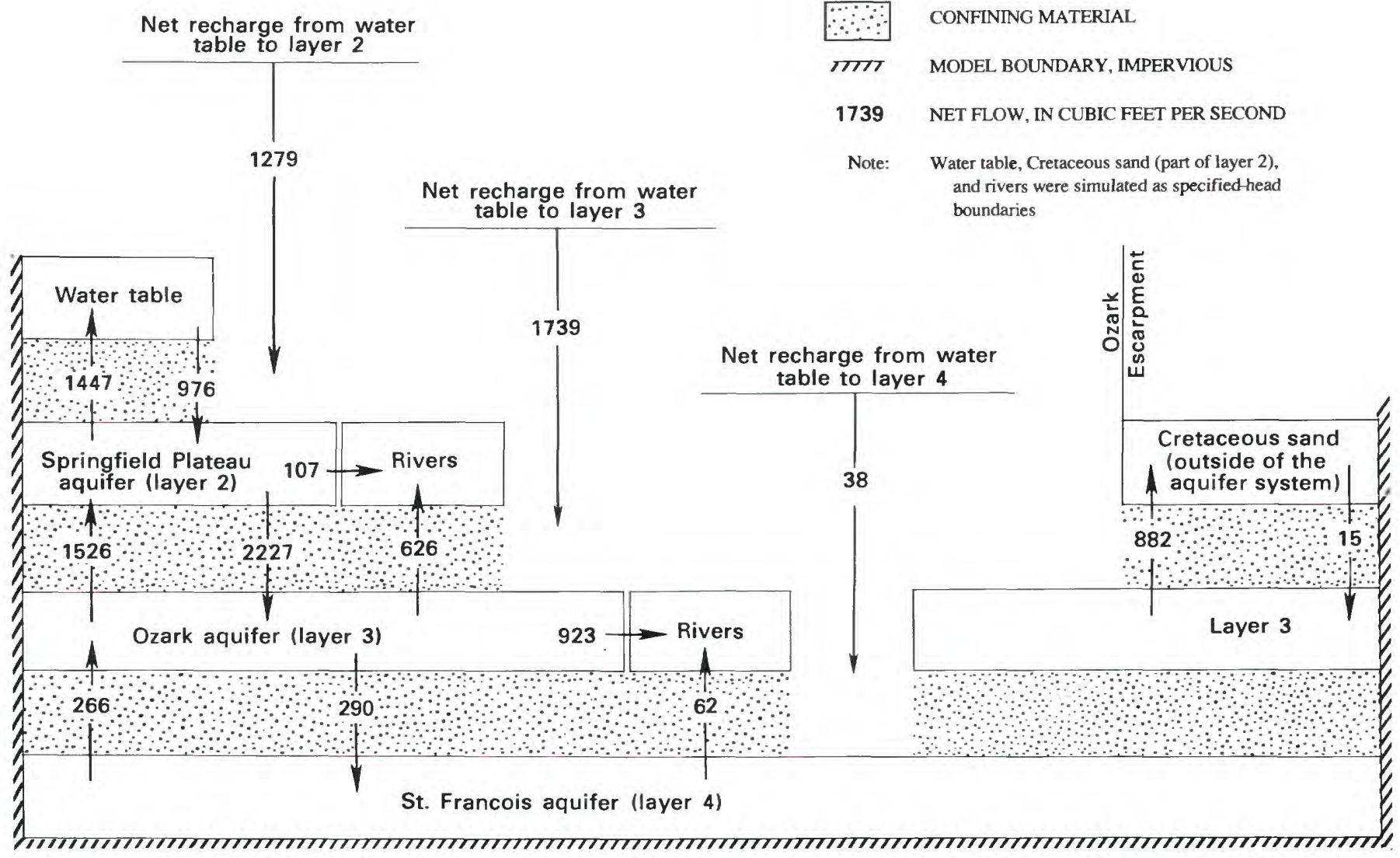

CONFINING MATERIAL

MODEL BOUNDARY, IMPERVIOUS

$\pi 77$

1739 NET FLOW, IN CUBIC FEET PER SECOND

Note: Water table, Cretaceous sand (part of layer 2), and rivers were simulated as specified-head boundaries

FiguRE 73.-Regional ground-water budget of the Ozark Plateaus aquifer system based on simulation. 
TABLE 3.-Water budgets for the Ozark Plateaus aquifer system

[Abbreviations: $A_{c}$, area of model cell; $A_{\mathrm{i}}$, area of cell in which precipitation entering water table appears to flow to sinks in same cell; $F_{\mathrm{B}}$, water that flows across cell boundaries and enters or leaves a cell through streambeds; $F_{\mathrm{u}}$, recharge to water table; $M$, recharge to area $A_{\mathrm{i}}$ that discharges to sinks within the cell divided by total recharge to area $A_{\mathrm{i}} ;$---, not applicable]

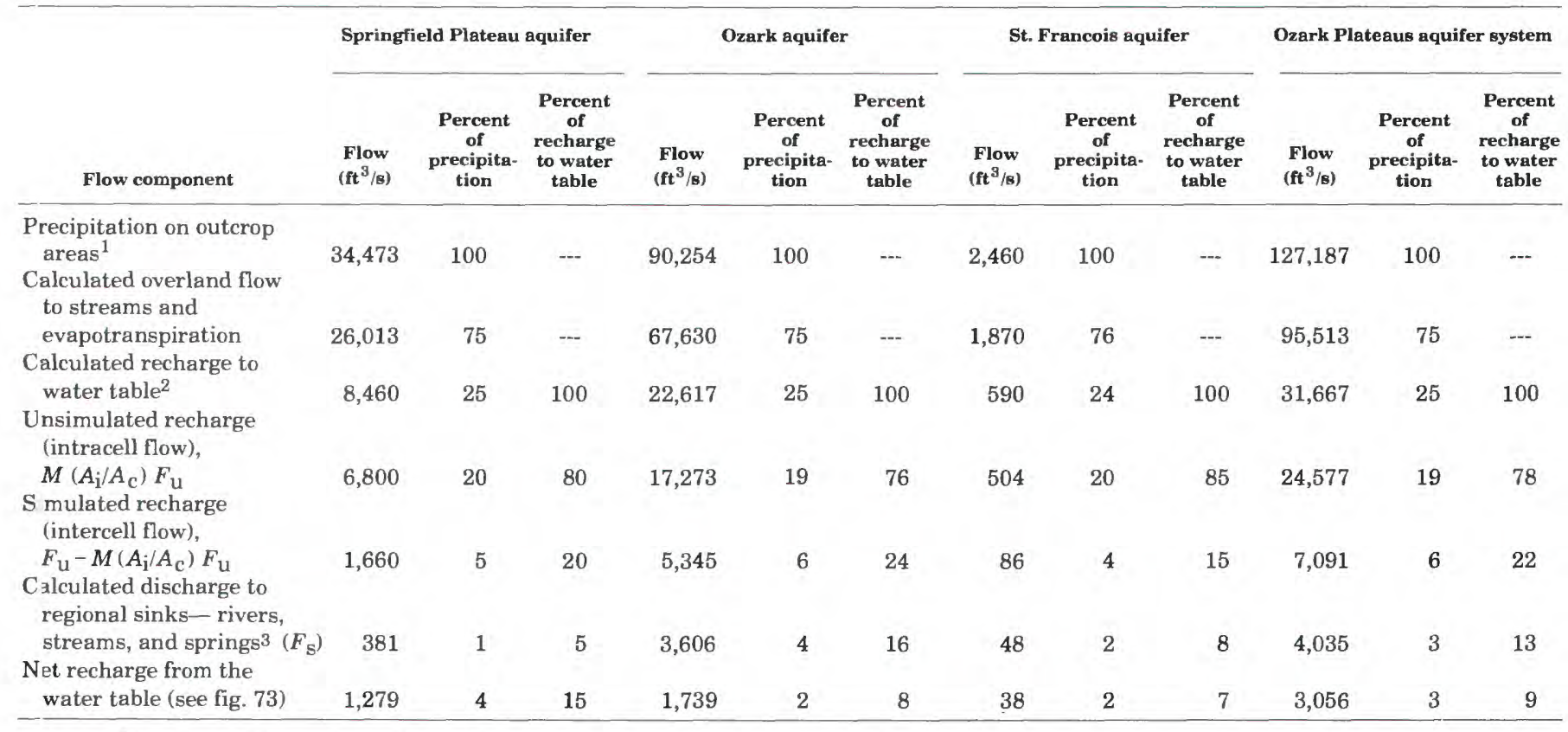

${ }^{1}$ From National Weather Service (National Oceanic and Atmospheric Administration, 1951-1980).

${ }^{2}$ From Dugan and Peckenpaugh (1986).

${ }^{3}$ From Hedman and others (1987).

ard 0.07 , respectively. In the Boston Mountains and Arkansas Valley of Arkansas the aquifer system contains more than 1,000 milligrams per liter dissolved solids. In these areas, the specific yields are estimated at one-half of the freshwater values. Estimates of the drainable water stored in the study area, in cubic feet, are listed below by State and aquifer:

\begin{tabular}{|c|c|c|c|}
\hline State & St. Francois aquifer & Ozark aquifer & $\begin{array}{c}\text { Springfield } \\
\text { Plateau } \\
\text { aquifer }\end{array}$ \\
\hline M: ssouri........................... & $2.37 \times 10^{13}$ & $1.45 \times 10^{14}$ & $5.15 \times 10^{12}$ \\
\hline 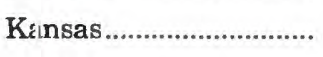 & $2.95 \times 10^{11}$ & $5.54 \times 10^{12}$ & $1.07 \times 10^{12}$ \\
\hline Ol:lahoma .......................... & $3.61 \times 10^{11}$ & $1.94 \times 10^{13}$ & $1.95 \times 10^{12}$ \\
\hline Arkansas (fresh) ........... & $2.21 \times 10^{12}$ & $7.73 \times 10^{13}$ & $1.30 \times 10^{12}$ \\
\hline Arkansas (saline)........... & $1.69 \times 10^{12}$ & $4.85 \times 10^{13}$ & $2.18 \times 10^{12}$ \\
\hline
\end{tabular}

\section{AVAILABILITY AND USE OF GROUND WATER AND WELL YIELDS}

It is estimated that approximately 200 million gallons per day of water are withdrawn from wells that are open to the Ozark Plateaus aquifer system (estimate based on records spanning 1970-1979). An estimate of ground water withdrawn daily in each county is shown in figure 74. The water is used for public supply, industrial use, domestic and stock use, and supplemental irrigation of crops. Large amounts of water also have been withdrawn in areas where underground mining has occurred. Withdrawal of ground water associated with underground mining has been limited to the St. Francois aquifer in southeastern Missouri and to the Springfield Plateau aquifer in the tristate mining district.

Although the Basement confining unit is considered to be a regional impermeable base for the Ozark Plateaus aquifer system, the unit does yield small quantities of water to wells via the extensive network of fracture systems and faults that dissect the confining unit. Water wells penetrate the Basement confining unit only in the immediate vicinity of the St. Francois Mountains where the unit crops out or is buried beneath thin overburden. Well yields are small and vary greatly within short distances. Of 14 water wells drilled into the Basement confining unit in or near its outcrop area, 70 percent yielded less than 10 gallons per minute. Two of these wells were 


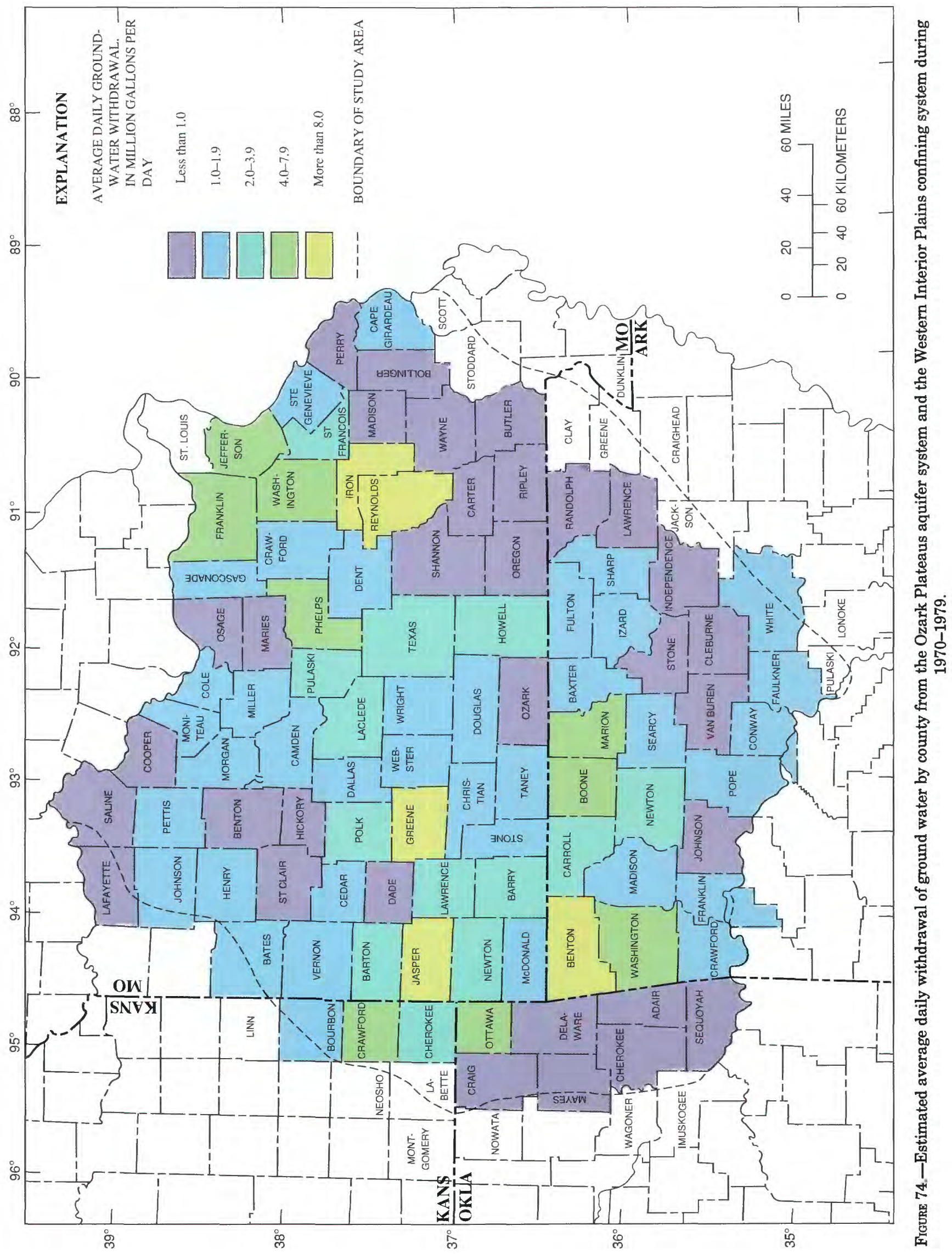


dry, including one drilled to a depth of 310 feet. The most productive of the four wells that yielded more than 10 gallons per minute was flowing and yielded about 70 gallons per minute.

Where the St. Francois aquifer crops out in and around the St. Francois Mountains the aquifer is used for domestic supply. Water from the St. Francois aquifer also is used for public supply where the overlying Ozark aquifer is thin or absent. For example, municipal wells at Farmington and Bismark in the St. Francois Mountains area yield 200 to 250 gallons per minute. Yields from wells that are open only to the Bonneterre Dolomite are somewhat less than those from wells also open to the Lamotte Sandstone. Wells that penetrate only the Bonneterre Dolomite in the outcrop area typically produce less than 50 gallons per minute, and the production rate may increase with well depth; however, this is not always the case. Many 200- to 300-foot-deep wells that are open only to the Bonneterre yield only a small amount of water (between 1 and $10 \mathrm{gal} / \mathrm{min}$ ). This indicates that in some areas the Bonneterre is tightly cemented and does not have well-developed secondary permeability. Those wells that are open to a significant thickness of Lamotte Sandstone usually have yields ranging from 100 to 500 gallons per minute.

The large withdrawal rates shown in figure 74 for Iron and Reynolds counties in Missouri reflect pumping from the St. Francois aquifer for uses associated with mining. Lead has been continuously mined in the eastern Ozarks of Missouri since the 1720's. Before 1869 , lead was mined from shallow pits above the water table. The introduction of the diamond drill for prospecting in 1869 led to new discoveries and extensive development of lead ore in the Bonneterre Dolomite below the water table, thus creating a need for mine dewatering. Ground water has been pumped to dewater mines, process ore (primarily lead and zinc), and supply the miners' domestic water needs. It was estimated that mines in the area, now known as the "Old Lead Belt," were being dewatered at the rate of 13 to 17 million gallons per day in the early 1900's (Buckley, 1908). Most of the mines in the "Old Lead Belt" were closed by the 1960's. Before that time, prospecting by mining companies had resulted in the discovery of a "New Lead Belt," known as the Viburnum Trend, that extends from near Viburnum in northwestern Reynolds County, Missouri, southward for more than 30 miles. As in the "Old Lead Belt," mineralization is in the Bonneterre Dolomite. Warner and others (1974) reported that ground water in the Viburnum Trend area was withdrawn at an average rate of 26 million gallons per day in 1971 for mine dewater- ing. Pumping rates at individual mines varied from 450 to 4,900 gallons per minute.

Mine dewatering has not had any lasting effect on water levels, as the mines in the "Old Lead Belt" district have refilled with water. Warner and others (1974), reporting on the effect of mine dewatering on ground-water levels in the Viburnum Trend, stated that no obvious decline in water levels in wells open to the shallow aquifer (Ozark aquifer) have been reported. However, they did mention that "a memorandum circulated by the U.S. Forest Service, Rolla, Missouri, on November 26, 1974, cited the recent development of a number of sizeable sinkholes in the vicinity of the AMAX Mine, which might be linked to declines in the shallow-aquifer water table in that area. This relationship has not been verified" (Warner and others, 1974, p. 75).

Throughout the Ozarks and adjacent areas, the Ozark aquifer is the primary source of water to large-yield public-supply, industrial, and irrigation wells. Yields from water wells that penetrate the Ozark aquifer vary somewhat according to the lithology of geohydrologic units that are open to the wells. Deep wells in the Salem Plateau commonly are open to the most permeable units of the aquifer and can yield more than 1,000 gallons per minute. However, shallower domestic wells that penetrate only a few hundred feet of the less permeable formations, such as the Jefferson City and Cotter Dolomites, may yield no more than 25 gallons per minute. In St. Louis and northern Jefferson Counties, Missouri, in the extreme northeastern part of the study area, well yields are, on the average, much smaller (less than 100 gallons per minute) than those in the Salem and Springfield Plateaus. Only formations stratigraphically higher than the Smithville Formation (table 2) normally are open to wells in this area because the underlying, more permeable zones of the aquifer are deeply buried and may locally contain salinewater.

The St. Peter Sandstone, the Roubidoux Formation, the Gunter Sandstone Member of the Gasconade Dolomite (also referred to in some areas as the Gunter Member of the Van Buren Formation), and the Potosi Dolomite are the formations within the Ozark aquifer that generally yield the largest amount of water to wells. The St. Peter Sandstone is present in the study area in eastern Missouri and in the Boston Mountains of Arkansas. Water wells open to the St. Peter Sandstone in Jefferson County, Missouri, produce between 50 and 75 gallons per minute (Fuller and others, 1967). The formation generally does not yield significant quantities of water in Arkansas. The overlying Plattin Limestone and Joachim Dolomite are sufficiently permeable to yield water to domestic wells in 
St. Louis and Jefferson Counties, Missouri, and in northern Arkansas. Silurian and Devonian limestone and chert of the upper zone are used locally as sources of domestic water in the northwestern and southern parts of the study area.

The Roubidoux Formation and Gasconade Dolomite of the Ozark aquifer are the principal water-bearing formations in northeastern Oklahoma, southeastern Kansas, northern Arkansas, and western Missouri. Water wells open to the Roubidoux Formation in those areas commonly yield 30 to 150 gallons per minute and occasionally as much as 600 gallons per minute. In southern Missouri where the Roubidoux Formation crops out or is present at shallow depth, it often is used as a source of water for domestic and farm wells. Such wells may yield as much as 20 gallons per minute. The Gunter Sandstone Member of the Gasconade Dolomite or the Van Buren Formation is a principal aquifer in Missouri, in northern Arkansas and in southeast Kansas. Wells open to the Gunter Sandstone Member commonly yield 40 to 100 gallons per minute and as much as 600 gallons per minute to wells in the Springfield, Missouri area (Fuller and others, 1967).

Yields from wells open to these and adjacent formations previously discussed can locally exceed 1,000 gallons per minute in northeastern Oklahoma (Marcher and Bingham, 1971). Melton (1976) attempted to assess the relative yields from the Roubidoux Formation and Gasconade Dolomite in the Ozark area. He concluded that yields from the Roubidoux Formation ranged from 4 to 600 gallons per minute and averaged 50 to 60 gallons per minute. Yields to wells open to the Gasconade Dolomite were reported to range from 4 to 732 gallons per minute and to average 170 gallons per minute. Melton presented some evidence that greater well yields in this area are obtained from wells located along fracture traces or major lineaments.

The Potosi Dolomite of the Ozark aquifer is one of the most reliable aquifers in Missouri for municipal and industrial water supply. In wells at Rolla, the Potosi at a depth of 1,200 feet is 200 feet thick and the yield, which is principally from the Potosi, averages 500 gallons per minute. At Springfield the Potosi is approximately 1,700 feet in depth and averages 50 feet in thickness. Fuller and others (1967) state that the combined production below the casing depth, usually 250 to 400 feet, is more than 1,000 gallons per minute.

Concentrated pumping has decreased heads in the Ozark aquifer locally at Miami, Oklahoma; Pittsburg, Kansas; and Springfield, Missouri. At Miami in Oklahoma, deep wells that flowed at the surface before 1907 showed a decline in water level of more than 400 feet by 1947. The decline in head was attributed to ground-water withdrawals as a result of greatly increased population and increased industrial use (Reed and others, 1955). Referring to Pittsburg, Kansas, Stramel (1957, p. 175) wrote that it has been "estimated that the use of water between 1882 and 1955 averaged $1.4 \mathrm{Mgal} / \mathrm{d}$. Available records indicate that the water level declined about 124 feet in the Pittsburg well field during this period of 73 years." At Springfield, industrial pumping from the Ozark aquifer has caused a cone of depression to form in the potentiometric surface. Static water levels in wells in the center of the cone have been lowered as much as 200 feet from their predevelopment condition.

Springs in the Springfield Plateau aquifer have served as a source of water for towns in Delaware, Mayes, and Adair Counties in Oklahoma (Dover and others, 1968). In Missouri the city of Springfield has long incorporated the use of a spring in its watersupply system, along with deep wells, lakes, and streams. Yields from wells penetrating the Springfield Plateau aquifer generally are less than yields from the thicker, somewhat more permeable Ozark aquifer. Wells that are open only to the Springfield Plateau aquifer usually are domestic-supply wells. To obtain greater yields, municipal wells that are open to the Springfield Plateau aquifer also are open to the underlying Ozark aquifer. Yields in the Springfield Plateau of southwestern Missouri commonly are less than 20 gallons per minute. However, there are industrial wells in Jasper County, Missouri, that yield 300 to 400 gallons per minute from fractured zones in the Springfield Plateau aquifer. The Burlington and Keokuk Limestones of the Springfield Plateau aquifer are the main water-yielding formations in this area. In the tristate mining district (Missouri-Kansas-Oklahoma), ground water is pumped from abandoned lead-zinc mine shafts to supply some industries. Yields from the mine shafts can exceed 1,000 gallons per minute.

In northeastern Oklahoma, water for domestic use is obtained from cherty limestones (Marcher, 1969; Marcher and Bingham, 1971) of the Springfield Plateau aquifer. Yields usually are less than 10 gallons per minute; however, larger yields are reported in Ottawa County, Oklahoma. In northern Arkansas, wells penetrating fractures and solution channels in the Boone Formation of the Springfield Plateau aquifer are reported to yield more than 25 gallons per minute (Lamonds, 1972).

Large amounts of water were pumped from the Springfield Plateau aquifer in conjunction with the mining and processing of the lead-zinc ore from the tristate mining district. The large mining district in- 
cludes parts of southwestern Missouri, southeastern Kansas, and northeastern Oklahoma. The ore occurs in Mississippian limestone within the Springfield Plateau aquifer. Mining in the Missouri part of the district lasted from about 1850 to about 1957, peaking about 1916. Mining in the Oklahoma and Kansas parts of the district began around 1900, peaked about 1926, and ceased in the early 1970's. Mine dewatering indicated that large yields of ground water were available in some localities. For example, Abernathy (1941, p. 234) stated that some pumping plants at zinc mines pumped as much as 2 million gallons per day to dewater the mines.

Mine cavities in the tristate mining district have refilled with water since being shut down. It has been estimated (Spruill, 1984) that the volume of water filling the mines is about 132,000 acre-feet (43 billion gallons). Unfortunately, the mine water is of poor quality for most uses and may present a threat of contamination to the underlying Ozark aquifer.

Water-bearing sandstone and limestone zones in the Western Interior Plains confining system are in rocks of Pennsylvanian age and are present near land surface in the western and southern part of the study area. The rocks have little permeability, and wells finished in these rocks invariably yield small quantities of water suitable only for domestic and stock use. Well-recovery tests on 14 shallow wells that penetrated the Western Interior Plains confining unit near the western boundary of the Ozark area in southwestern Missouri displayed a range of yields from 1 to $\mathbf{4 0}$ gallons per minute (Kleeschulte and others, 1985). Generally, well yields tended to increase from west to east. This may indicate that the easternmost wells, located where the confining system is thinner, were receiving ground water from the underlying Springfield Plateau aquifer through the more permeable sandstones at the base of the confining system. Similar tests conducted on 16 shallow wells that penetrated the Western Interior Plains confining unit in southwestern Washington County, Arkansas, show that well yields in this area also are small, ranging from 2.5 to 19 gallons per minute (Muse, 1982). Water comes to these wells from water-yielding units such as the Hale Formation and perhaps the Pitkin Limestone. Other formations that the wells penetrate are likely to have a much larger shale fraction and presumably yield less water.

\section{SUMMARY AND CONCLUSIONS}

The Ozark area contains eight regional geohydrologic units and several smaller units. Five of the geo- hydrologic units-three aquifers and two confining units-form the mainly freshwater Ozark Plateaus aquifer system. The aquifer system is confined below by the Basement confining unit. The western and southern edges of the aquifer system are confined above by the Western Interior Plains confining system. The aquifers and confining units that constitute the Ozark Plateaus aquifer system are, in ascending order, the St. Francois aquifer, the St. Francois confining unit, the Ozark aquifer, the Ozark confining unit, and the Springfield Plateau aquifer.

The Missouri River alluvial valley is the northern boundary and a discharge area for the Ozark Plateaus aquifer system. On the east the Mississippi River alluvial valley is the approximate boundary from its confluence with the Missouri River southward to the Mississippi Alluvial Plain. The aquifer system extends a short distance beneath the alluvial plain to the southeast. The southern boundary is approximately parallel to the Arkansas River valley. The western boundary is a complex transition zone where freshwater in the Ozark Plateaus aquifer system meets salinewater in the stratigraphically equivalent Western Interior Plains aquifer system.

There are two regional ground-water divides in the study area. The northernmost divide parallels a prominent topographic ridge that extends through the Ozark Plateaus from McDonald to Dent County, Missouri (figs. 3, 10). Ground water flowing north from the divide discharges to the Missouri River. Ground water flowing south from the divide discharges to the White River and its tributaries. The southernmost regional ground-water divide parallels the crest of the Boston Mountains in northern Arkansas. North of this divide, water in the aquifer system flows to the White and Buffalo Rivers and their tributaries.

The Basement confining unit is a nearly impermeable barrier to the movement of ground water relative to the overlying aquifers. Primary porosity and permeability of the Basement confining unit are virtually nonexistent in the Precambrian rocks that constitute this unit. Secondary permeability has developed but mainly is confined to fracture zones and faults. The largest exposure of the Basement confining unit is in the St. Francois Mountains of southeast Missouri. From this area the unit dips steeply into the subsurface toward basins that surround the Ozark uplift. Water wells penetrate the unit only in the immediate vicinity of its outcrop or where the unit is buried beneath thin overburden. Well yields are small, vary considerably within short distances, and generally yield less than 10 gallons per minute. 
Three geologic formations, the Lamotte Sandstone, the Bonneterre Dolomite, and in the western part of the study area, the Reagan Sandstone, are included in the St. Francois aquifer. The water-bearing sandstone, dolostone, and siltstone overlie the Basement confining unit. The St. Francois aquifer crops out in the St. Francois Mountains of southeastern Missouri. Beyond the relatively small outcrop area the aquifer dips into the subsurface and is buried beneath younger, more permeable rocks. The St. Francois aquifer generally is more than 300 feet thick in southern Missouri. In northern Arkansas, the aquifer ranges between 100 and 300 feet thick. In the western and southwestern part of the study area, the aquifer generally is less than 300 feet thick and thins toward the west.

Water levels in the St. Francois aquifer are controlled by topographic features in the outcrop area. Within the outcrop area, discharge from the aquifer is to the major streams. Near the outcrop area, where the aquifer is confined but not deeply buried, ground water discharges through the overlying confining unit and thence to the major streams. Little is known about the potentiometric surface of the St. Francois aquifer where it is deeply buried because no wells are open to the aquifer.

The few water-quality data available for the St. Francois aquifer are from water samples in and near its outcrop area, where the water type generally is a calcium magnesium bicarbonate. Dissolved-solids concentration generally ranges from 200 to 400 milligrams per liter. Chloride concentration generally ranges from 5 to 60 milligrams per liter. Sulfate concentration may be as large as $\mathbf{1 5 0}$ milligrams per liter but generally is much less.

The St. Francois aquifer is used primarily in and near its outcrop area. Wells penetrating only the Bonneterre Dolomite generally yield less than 50 gallons per minute. Many 200- to 300-foot-deep wells open only to the Bonneterre Dolomite yield less than 10 gallons per minute. Wells open to a significant thickness of Lamotte Sandstone may yield 100 to 500 gallons per minute.

The St. Francois confining unit is composed of Upper Cambrian shale, siltstone, dolostone, and limestone. It is represented by the Davis Formation and the Derby and Doe Run Dolomites. These slightly permeable rocks retard the flow of ground water between the St. Francois and Ozark aquifers. The St. Francois confining unit is exposed at land surface in a thin, nearly circular band around the St. Francois Mountains.

Thickness of the St. Francois confining unit ranges from near 0 to 730 feet. Throughout much of the
Salem Plateau, the confining unit has a relatively constant thickness between 200 and 400 feet. At the northwest edge of the Mississippi Alluvial Plain the unit is more than 600 feet thick. In the southwestern part of the study area, thickness of the confining unit seldom exceeds 100 feet. In northern Arkansas, thickness of the confining unit generally ranges between 100 and 400 feet, but is greater than 730 feet in Madison County, Arkansas (fig. 3).

The Ozark aquifer includes a sequence of Upper Cambrian and Middle Devonian rocks that vary in water-yielding capacity but collectively are a regional aquifer. The Potosi Dolomite is the basal formation in the aquifer. The upper boundary of the aquifer in the northeast part of the study area is the base of the Maquoketa Shale. To the west and south where the Maquoketa Shale is absent, Devonian rocks are included as part of the aquifer, and the upper boundary of the aquifer is the base of the Chattanooga Shale. The outcrop area of the Ozark aquifer is approximately coincident with the Salem Plateau.

The Ozark aquifer is the thickest aquifer in the study area. Northeast, east, and south of the St. Francois Mountains, the aquifer is more than 3,000 feet thick. In southwestern Missouri, southeastern Kansas, and northeastern Oklahoma, the aquifer ranges from 800 to 1,500 feet thick. The aquifer is about 1,500 feet thick near the Missouri-Arkansas border and increases in thickness southward.

The aquifer is made up of dolostone, limestone, sandstone, chert, and shale; dolostone is the predominant rock in most of the study area. Dissolution of the carbonate rock along fractures and bedding planes and karst development are the main processes that develop permeability in the aquifer. Hydraulic conductivity in the northern half of the study area, as estimated from specific-capacity data, varies from about $10^{-5}$ foot per second to about $10^{-3}$ foot per second. In the Arkansas Valley the hydraulic conductivity is as little as $10^{-8}$ foot per second.

Ground water in the Ozark aquifer in the Salem Plateau is unconfined. Water levels in the aquifer are strongly influenced by major topographic features of the plateau. Ground-water movement in the aquifer in the Salem Plateau is from the upland areas between rivers and streams toward the valleys where the water discharges as base flow. Beyond the boundaries of the Salem Plateau, the Ozark aquifer is confined and water in the aquifer generally flows away from the Ozark Plateaus province toward surrounding areas where the deep aquifers contain saline ground water.

Water from the Ozark aquifer generally is a calcium magnesium bicarbonate type. Dissolved-solids 
concentration ranges from 200 to 300 milligrams per liter along the regional ground-water divides and is as much as $\mathbf{5 0 0}$ milligrams per liter in the northcentral part of the Salem Plateau where the Ozark aquifer is overlain by Pennsylvanian shale and sandstone. Chloride concentration of water from the Ozark aquifer generally is less than 10 milligrams per liter but increases significantly away from the Ozark Plateaus province. Sulfate concentration of water from the aquifer generally is less than 10 milligrams per liter in the Salem Plateau and less than 20 milligrams per liter in the Springfield Plateau. However, in the north-central part of the Salem Plateau, sulfate concentration of water in the aquifer is as much as $\mathbf{1 4 0}$ milligrams per liter. Several small areas of the Ozark aquifer along the western and southern flanks of the Ozark Plateaus province contain a sodium bicarbonate or a mixed bicarbonate type water. These are areas indicative of the transition between the predominantly bicarbonate water in the Ozark Plateaus aquifer system and the predominantly sodium chloride water that encircles the aquifer system to the west, south, and east.

Yields from deep wells in the Salem Plateau open to the Ozark aquifer may exceed 1,000 gallons per minute. Shallower domestic wells that penetrate only a few hundred feet of the less permeable rocks of the aquifer may yield less than 25 gallons per minute. The Potosi Dolomite is the most permeable geologic formation within the aquifer. The Roubidoux Formation and Gasconade Dolomite form the main wateryielding formations of the aquifer in the southwestern and southern parts of the study area.

The Ozark confining unit includes the stratigraphic interval from the Upper Ordovician Maquoketa Shale to the Lower Mississippian Chouteau Limestone. The confining unit is not present in the Salem Plateau where the stratigraphically lower Ozark aquifer is exposed at land surface. Thickness of the Ozark confining unit ranges from near 0 to more than 1,500 feet. In most of the study area, however, the confining unit is less than 100 feet thick. Slightly permeable strata of the Ozark confining unit impede the movement of ground water between the underlying Ozark aquifer and the overlying Springfield Plateau aquifer.

The Springfield Plateau aquifer is a sequence of water-bearing Mississippian limestones. In western Missouri and southeastern Kansas, the Burlington and Keokuk Limestones are the most significant formations in the Springfield Plateau aquifer. In northeastern Oklahoma, rocks of the aquifer are the Boone Formation, the Keokuk Limestone, and the Moorefield Formation. In northern Arkansas, the aquifer is represented by the Boone Formation.
The Springfield Plateau aquifer crops out over about one-third of the Ozark Plateaus province as a wide band around the western and southern perimeter of the Salem Plateau. The aquifer is buried beneath Pennsylvanian rocks west of the Springfield Plateau to a depth of about 250 feet in the more northerly areas and to about 500 feet in southeastern Kansas. The aquifer ranges from 200 to 400 feet thick throughout most of southwestern Missouri and southeastern Kansas. In northeastern Oklahoma, the aquifer may exceed 300 feet in thickness. In northern Arkansas, the aquifer generally is less than 400 feet thick.

Water from the Springfield Plateau aquifer is a calcium bicarbonate type. In the outcrop area, dissolvedsolids concentration of the water generally is less than 300 milligrams per liter but may exceed 400 milligrams per liter. Chloride concentration in water from the aquifer generally is less than 10 milligrams per liter but in northwest Arkansas can exceed 100 milligrams per liter. Sulfate concentration in water from the aquifer generally is less than 10 milligrams per liter but is larger in water from the zinc-lead mines in the tristate mining district.

The Springfield Plateau aquifer is used as a source of water for farm wells, but the aquifer rarely is used for public supply because of small well yields. Yields from wells that penetrate the Springfield Plateau aquifer in southwestern Missouri commonly are less than $\mathbf{2 0}$ gallons per minute. Springs from the aquifer, however, have been a source of supply for towns in Oklahoma, Missouri, and Arkansas.

Regionally, the Western Interior Plains confining system generally impedes the vertical and lateral flow of water. However, individual formations that constitute the confining system locally may be aquifers or confining units. Wells open to aquifers in the confining system generally have small yields and are capable of supplying water only for domestic and stock uses. The configuration of the water table in the near-surface weathered layer of the confining system is affected by topography. Generally, ground water infiltrates to the water table in upland areas, then moves toward the stream valleys where it discharges.

A three-dimensional finite-difference model was constructed to simulate regional ground-water flow in the Ozark Plateaus aquifer system under predevelopment conditions. Because of the large area (195.3 $\mathrm{mi}^{2}$ ) represented by each model cell, the large topographic relief of the surficial aquifers, and the hydrologic complexity of the karst terrane, a new method of estimating the distribution of recharge to the uppermost model cells was developed. The method uses 
independent estimates of (1) recharge to the water table, (2) base flow and hydrologic characteristics of springs and streams, and (3) topographic features to determine the net flux that contributes to intercell flow for each model cell that receives recharge. The calculated net flux (or regional ground-water recharge) ranges from 12 to 100 percent of the estimated recharge to the water table, depending on the hydrologic conditions at a particular cell. The steadystate model cahibration yielded estimates of the lateral hydraulic conductivity of the St. Francois, Ozark, and Springfield Plateau aquifers. The lateral hydraulic conductivity of the St. Francois aquifer ranges from $1.6 \times 10^{-4}$ foot per second near the St. Francois Mountains to $8.0 \times 10^{-5}$ foot per second elsewhere. The lateral hydraulic conductivity of the Ozark aquifer ranges from $1.0 \times 10^{-5}$ foot per second in the south to $8.0 \times 10^{-4}$ foot per second in the north and east. The lateral hydraulic conductivity of the Springfield Plateau aquifer is uniform at $2.5 \times 10^{-4}$ foot per second.

A water budget for the Ozark Plateaus aquifer system shows that prior to development only 6 percent of the mean annual precipitation in the aquifer system outcrop area contributed to the deeper regional ground-water flow that is simulated. About 25 percent of the 127,187 cubic feet per second of precipitation on the aquifer system outcrop area percolated to the water table. Of the water that entered the water table, about 78 percent was intracell flow that discharged into nearby streams and springs. This water is not simulated in the flow model. The remaining 7,091 cubic feet per second (6 percent of precipitation) became regional ground-water flow and is simulated. Of this regional flow, 4,035 cubic feet per second of water discharged to regional sinks (large streams and lakes) inside the study area, and 3,056 cubic feet per second of water discharged as boundary flow to the Mississippi, Missouri, Neosho, and Arkansas Rivers, aquifers of the Mississippi Embayment, and the water table in the Western Interior Plains confining system. Because pumping rates are small compared to the large natural rates of recharge and discharge, the regional ground-water budget prior to development probably is similar to the present-day budget.

Approximately 200 million gallons per day of ground water are withdrawn from the Ozark Plateaus aquifer system by large-yield public-supply, industrial, and irrigation wells in the Ozarks and adjacent areas. The quantity of ground water pumped for irrigation varies from year to year depending upon rainfall received during the growing season. There does not seem to be any regional lowering of water levels in the aquifer system. However, concentrated pumping has decreased heads in the Ozark aquifer locally at Miami, Oklahoma; Pittsburg, Kansas; and Springfield, Missouri. With the exception of mine dewatering, use of water from the St. Francois aquifer is limited to its area of outcrop and adjacent areas where the overlying Ozark aquifer is thin or absent. Pumping from the St. Francois aquifer for the purpose of dewatering lead mines in the Viburnum Trend averaged 26 million gallons per day in 1971.

\section{SELECTED REFERENCES}

Allingham, J.W., 1960, Interpretation of aeromagnetic anomalies in southeast Missouri, in Short papers in the geological sciences, Chapter B of Geological Survey Research 1960: U.S. Geological Survey Professional Paper 400-B, p. B216-B219.

Abernathy, G.E., 1941, Ground-water resources of Mississippian and older rocks in Bourbon, Crawford, Cherokee, and Labette Counties, southeastern Kansas: Kansas Geology Survey Bulletin 38, Reports Studies 1941, part 8, p. 221-236.

Anderson, R.E., 1970, Ash-flow tuffs of Precambrian age in southeast Missouri: Rolla, Missouri Division of Geology and Land Survey, Report of Investigations No. 46, $50 \mathrm{p}$.

Barks, J.H., 1977, Effects of abandoned lead and zinc mines and tailings piles on water quality in the Joplin area, Missouri: U.S. Geological Survey Water-Resources Investigations Report 77-75, 49 p.

1978, Water quality in the Ozark National Scenic Riverways, Missouri: U.S. Geological Survey Water-Supply Paper 2048, 57 p.

Bedinger, M.S., Emmett, L.F., and Jeffery, H.G., 1963, Groundwater potential of the alluvium of the Arkansas River between Little Rock and Fort Smith, Arkansas: U.S. Geological Survey Water-Supply Paper 1669-L, 29 p.

Bennett, G.D., 1979, Regional ground-water systems analysis: U.S. Army Corps of Engineers, Water Resources Support Center, Fort Belvoir, Virginia, Water Spectrum, v. 11, no. 4, p. 36-42.

Brahana, J.V., and Mesko, T.O., 1988, Hydrogeology and preliminary assessment of regional flow in the upper Cretaceous and adjacent aquifers in the northern Mississippi Embayment: U.S. Geological Survey Water-Resources Investigations Report 87-4000, 65 p.

Bretz, J H., 1953, Genetic relations of caves to peneplains and big springs in the Ozarks: American Journal of Science, v. 251, p. 1-24.

1965, Geomorphic history of the Ozarks of Missouri: Rolla, Missouri Division of Geology and Land Survey, 2nd ser., v. 41, $147 \mathrm{p}$.

Buckley, E.R, 1908, Geology of the disseminated lead deposits of St. Francois and Washington Counties, Missouri: Rolla, Missouri Division of Geology and Land Survey, v. 9, part 1, 259 p.

Caplan, W.M., 1954, Subsurface geology and related oil and gas possibilities of northeastern Arkansas: Arkansas Resources and Development Commission, Bulletin 20, 124 p.

-1957, Subsurface geology of northwestern Arkansas: Arkansas Geological and Conservation Commission Information Circular 19, 14 p., $17 \mathrm{pl}$.

-1960, Subsurface geology of pre-Everton rocks in northern Arkansas: Arkansas Geological and Conservation Commission Information Circular 21, $17 \mathrm{p}$. 
Cole, V.B., 1962, Configuration on top of Precambrian basement rocks in Kansas: Kansas Geological Survey, Oil Gas Investigations, no. 26, scale 1:633,600, 1 sheet.

-1975, Subsurface Ordovician-Cambrian rocks in Kansas: Kansas Geological Survey Subsurface Geology Series 2, 18 p.

Cole, V.B., and Ebanks, W.J., Jr., 1979, List of Kansas wells drilled into Precambrian rocks: Kansas Geological Survey Subsurface Geology Series 3, 107 p.

Cushing, E.M., Boswell, E.H., and Hosman, R.L., 1964, General geology of the Mississippi Embayment: U.S. Geological Survey Professional Paper 448-B, 28 p.

Darton, N.H., 1905, Preliminary list of the deep borings in the United States: U.S. Geological Survey Water-Supply Paper 149,175 p.

Denison, R.E., 1981, Basement rocks in northeastern Oklahoma: Oklahoma Geological Survey Circular 84, 84 p.

Dinwiddie, G.A., 1979, Plan of study for the Northern Great Plains Regional Aquifer-System Analysis in parts of Montana, North Dakota, South Dakota, and Wyoming: U.S. Geological Survey Water-Resources Investigations Report 79-34, 20 p.

Dover, T.B., Leonard, A.R., and Laine, L.L., 1968, Water for Oklahoma: U.S. Geological Survey Water-Supply Paper 1890, 107 p.

Dugan, J.T., and Peckenpaugh, J.M., 1986, The effects of climate on consumptive water use and ground-water recharge in parts of Arkansas, Colorado, Kansas, Missouri, Nebraska, Oklahoma, South Dakota, and Texas: U.S. Geological Survey WaterResources Investigations Report 85-4326, $78 \mathrm{p}$.

Edds, Joe, and Fitzpatrick, D.J., 1984, Maps showing altitude of the potentiometric surface and changes in water levels of the alluvial aquifer in eastern Arkansas, spring 1983: U.S. Geological Survey Water-Resources Investigations Report 844264, 1 sheet.

Emmett, L.F., and Imes, J.L., 1984, Ground-water resources of Audrain County, Missouri: U.S. Geological Survey Open-File Report 84-245, 55 p.

Emmett, L.F., and Jeffery, H.G., 1968, Reconnaissance of the ground-water resources of the Missouri River alluvium between St. Charles and Jefferson City, Missouri: U.S. Geological Survey Hydrologic Investigations Atlas HA-315, 1 sheet.

1969, Reconnaissance of the ground-water resources of the Missouri River alluvium between Jefferson City and Miami, Missouri: U.S. Geological Survey Hydrologic Investigations Atlas HA-340, 1 sheet.

Emmett, L.F., Skelton, John, Luckey, R.R., and Miller, D.E., 1978, Water resources and geology of the Springfield area, Missouri: Rolla, Missouri Division of Geology and Land Survey WaterResources Report 34, $150 \mathrm{p}$.

Ervin, C.P., and McGinnis, L.D., 1975, Reelfoot rift-Reactive precursor to the Mississippi Embayment: Geological Society of America Bulletin, v. 86, p. 1287-1295.

Feder, G.L., 1970, A semiquantitative method for determining the source of springflow in the Missouri Ozarks, in Geological Survey Research 1970: U.S. Geological Survey Professional Paper 700-C, p. C214-C217.

1979, Geochemical survey of waters of Missouri: U.S. Geological Survey Professional Paper 954-E, 78 p.

Feder, G.L., Skelton, John, Jeffery, H.G., and Harvey, E.J., 1969, Water resources of the Joplin area, Missouri: Rolla, Missouri Division of Geology and Land Survey Water-Resources Report 24, $97 \mathrm{p}$.

Fenneman, N.M., 1938, Physiography of eastern United States: New York, McGraw-Hill, 714 p.

Fletcher, C.S., 1974, The geology and hydrogeology of the New Lead Belt, Missouri: Rolla, University of Missouri, M.S. thesis, $82 \mathrm{p}$.
Freiwald, D.A., 1985, Average annual precipitation and runoff for Arkansas, 1951-80: U.S. Geological Survey Water-Resources Investigations Report 84-4363, 1 sheet.

1987, Streamflow gain and loss of selected streams in northern Arkansas: U.S. Geological Survey Water-Resources Investigations Report 86-4185, 4 sheets.

Frick, D.R., 1980, Hydrogeology of Mississippian and Ordovician aquifers in southwest Missouri and southeast Kansas: Columbia, University of Missouri, M.S. thesis, $96 \mathrm{p}$.

Fuller, D.L., Knight, R.D., and Harvey, E.J., 1967, Ground water, in Mineral and water resources of Missouri: Rolla, Missouri Division of Geology and Land Survey, v. 43, 2d ser., 399 p.

Gann, E.E., Harvey, E.J., Barks, J.H., Fuller, D.L., and Miller, D.E., 1974, Water resources of west-central Missouri: U.S. Geological Survey Hydrologic Investigations Atlas HA-491, 4 sheets.

Gann, E.E., Harvey, E.J., and Miller, D.E., 1976, Water resources of south-central Missouri: U.S. Geological Survey Hydrologic Investigations Atlas HA-550, 4 sheets.

Gerdemann, P.E., and Myers, H.E., 1972, Relationships of carbonate facies patterns to ore distribution and to ore genesis in the southeast Missouri lead district: Economic Geology, v. 67, p. $426-433$.

Gleason, C.D., 1935, Underground water in St. Louis County, and City of St. Louis, Missouri: Rolla, Missouri Division of Geology and Land Survey, 58th Biennial Report, appendix 5, 24 p.

Grubb, H.F., 1984, Planning report for the Gulf Coast Regional Aquifer-System Analysis in the Gulf of Mexico Coastal Plain, United States: U.S. Geological Survey Water-Resources Investigations Report 84-4219, 30 p.

Haley, B.R., 1965, Geologic formations penetrated by the Shell Oil Company No. 1 Western Coal and Mining Co. well on the Backbone Anticline, Sebastian County, Arkansas: Arkansas Geological Commission Information Circular 20-D, 17 p.

Harvey, E.J., 1980, Ground water in the Springfield-Salem Plateaus of southern Missouri and northern Arkansas: U.S. Geological Survey Water-Resources Investigations 80-101, $66 \mathrm{p}$.

Harvey, E.J., Skelton, John, and Miller, D.E., 1983, Hydrology of carbonate terrane-the Niangua, Osage Fork, and Grandglaize Creek basins, Missouri: Rolla, Missouri Division of Geology and Land Survey Water-Resources Report 35, 132 p.

Havens, J.S., 1978, Ground-water records for eastern Oklahoma part 2-Water-quality records for wells, test holes, and springs: U.S. Geological Survey Open-File Report 78-357, $139 \mathrm{p}$.

Hedman, E.R., Skelton, John, Freiwald, D.A., 1987, Flow characteristics for selected springs and streams in the Ozark subregion, Arkansas, Kansas, Missouri, and Oklahoma: U.S. Geological Survey Hydrologic Investigations Atlas HA-688, 4 sheet(s).

Howe, W.B., Kurtz, V.E., and Anderson, K.H., 1972, Correlation of Cambrian strata of the Ozark and upper Mississippi valley regions: Rolla, Missouri Division of Geology and Land Survey Report of Investigations 52, $60 \mathrm{p}$.

Huffman, G.G., 1958, Geology of the flanks of the Ozark Uplift, northeastern Oklahoma: Oklahoma Geological Survey Bulletin 77, $281 \mathrm{p}$.

Hyndman, D.W., 1972, Petrology of igneous and metamorphic rocks, of International series in the earth and planetary sciences: New York, McGraw-Hill, 533 p.

Imes, J.L., 1985, The ground-water flow system in northern Missouri with emphasis on the Cambrian-Ordovician aquifer: U.S. Geological Survey Professional Paper 1305, 61 p., 1 plate.

1989, Major geohydrologic units in and adjacent to the Ozark Plateaus province, Missouri, Arkansas, Kansas, and 
Oklahoma-Basement confining unit: U.S. Geological Survey Hydrologic Investigations Atlas HA-711-B, 1 sheet.

-1990a, Major geohydrologic units in and adjacent to the Ozark Plateaus province, Missouri, Arkansas, Kansas, and Oklahoma: U.S. Geological Survey Hydrologic Investigations Atlas HA-711-A, 1 sheet.

1990b, Major geohydrologic units in and adjacent to the Ozark Plateaus province, Missouri, Arkansas, Kansas, and Oklahoma-St. Francois aquifer: U.S. Geological Survey Hydrologic Investigations Atlas HA-711-C, 2 sheets.

-1990c, Major geohydrologic units in and adjacent to the Ozark Plateaus province, Missouri, Arkansas, Kansas, and Oklahoma-St. Francois confining unit: U.S. Geological Survey Hydrologic Investigations Atlas HA-711-D, 3 sheets.

1990d, Major geohydrologic units in and adjacent to the Ozark Plateaus province, Missouri, Arkansas, Kansas, and Oklahoma-Ozark aquifer: U.S. Geological Survey Hydrologic Investigations Atlas HA-711-E, 3 sheets.

-1990e, Major geohydrologic units in and adjacent to the Ozark Plateaus province, Missouri, Arkansas, Kansas, and Oklahoma-Ozark confining unit: U.S. Geological Survey Hydrologic Investigations Atlas HA-711-F, 3 sheets.

-1990f, Major geohydrologic units in and adjacent to the Ozark Plateaus province, Missouri, Arkansas, Kansas, and Oklahoma-Springfield Plateau aquifer: U.S. Geological Survey Hydrologic Investigations Atlas HA-711-G, 3 sheets.

$-1990 \mathrm{~g}$, Major geohydrologic units in and adjacent to the Ozark Plateaus province, Missouri, Arkansas, Kansas, and Oklahoma-Western Interior Plains confining system: U.S. Geological Survey Hydrologic Investigations Atlas HA-711-H, 3 sheets.

Imes, J.L., and Davis, J.V., 1990a, Water type and concentration of dissolved solids, chloride, and sulfate in ground water from the St. Francois aquifer: U.S. Geological Survey Hydrologic Investigations Atlas HA-711-J, 1 sheet.

$1990 \mathrm{~b}$, Water type and concentration of dissolved solids, chloride, and sulfate in ground water from the Springfield Plateau aquifer: U.S. Geological Survey Hydrologic Investigations Atlas HA-711-L, 2 sheets.

1991, Water type and concentration of dissolved solids, chloride, and sulfate in ground water from the Ozark aquifer: U.S. Geological Survey Hydrologic Investigations Atlas HA-711-K, 4 sheets.

Imes, J.L., and Smith, B.J., 1990, Geohydrologic units of southern Missouri: U.S. Geological Survey Hydrologic Investigations Atlas HA-711-I, 3 sheets.

Jorgensen, D.G., Helgesen, J.O., and Imes, J.L., 1993, Regional aquifers in Kansas, Nebraska, and parts of Arkansas, Colorado, Missouri, New Mexico, Oklahoma, South Dakota, Texas, and Wyommg-Geologic framework: U.S. Geological Survey Professional Paper 1414-B, $72 \mathrm{p}$.

Jorgensen, D.G., and Rosenshein, J.S., 1987, Naming Aquifers: EOS, American Geophysical Union, v. 68, no. 15, p. 210-211.

Jorgensen, D.G., and Signor, D.C., 1981, Plan of study for the Central Midwest Regional Aquifer-Systems Analysis in parts of Arkansas, Colorado, Kansas, Missouri, Nebraska, New Mexico, Oklahoma, South Dakota, and Texas: U.S. Geological Survey Water-Resources Investigations Open-File Report 81-206, 28 p.

Kane, M.F., Hildenbrand, T.G., and Hendricks, J.D., 1981, Model for the tectonic evolution of the Mississippi Embayment and its contemporary seismicity: Geology, v. 9, no. 12, p. 563-568.

Kisvarsanyi, E.B., 1975, Data on the Precambrian in drillholes in Missouri, including rock type and surface configuration: Rolla, Missouri Division of Geology and Land Survey Report of Investigations 56, $20 \mathrm{p}$.
1979, Geologic map of the Precambrian of Missouri: Rolla, Missouri Division of Geology and Land Survey Contribution to Precambrian Geology 7, scale 1:1,000,000.

1981, Geology of the Precambrian St. Francois terrane, southeastern Missouri: Rolla, Missouri Division of Geology and Land Survey Report of Investigations 64, 58 p.

Kisvarsanyi, Geza, and Martin, J.A., 1977, Structural lineament and pattern analysis of Missouri, using Landsat imagery: National Technical Information Service, E-77-10239.

Kleeschulte, M.J., Mesko, T.O., and Vandike, J.E., 1985, Appraisal of the ground-water resources of Barton, Vernon, and Bates Counties, Missouri: Rolla, Missouri Division of Geology and Land Survey Water-Resources Report 36, 74 p.

Koenig, J.W., ed., 1961, The stratigraphic succession in Missouri: Rolla, Missouri Division of Geology and Land Survey, v. 40, 2nd series, $185 \mathrm{p}$.

Kurtz, V.E., Thacker, J.L., Anderson, K.M., and Gerdemann, P.E., 1975, Traverse in Late Cambrian strata from the St. Francois Mountains, Missouri, to Delaware County, Oklahoma: Rolla, Missouri Division of Geology and Land Survey Report of Investigations 55, $112 \mathrm{p}$.

Lamonds, A.G., 1972, Water-resources reconnaissance of the Ozark Plateaus province, northern Arkansas: U.S. Geological Survey Hydrologic Investigations Atlas HA-383, 1 sheet.

Leatherock, Constance, and Bass, N.W., 1936, Chattanooga Shale in Osage County, Oklahoma, and adjacent areas: Bulletin of the American Association of Petroleum Geologists, v. 20, no. 1, p. 91-101.

Lidiak, E.G., Marvin, R.F., Thomas, H.H., Bass, M.N., 1966, Eastern area, part 4 of Geochronology of the midcontinent region, United States: Journal of Geophysical Research, v. 71, p. $5427-5438$.

Lillie, R.J., Nelson, K.D., de Voogd, B., Brewer, J.A., Oliver, J.E., Brown, L.D., Kaufman, S., and Viele, G.W., 1983, Crustal structure of Oauchita Mountains, Arkansas-A model based on integration of COCORP reflection profiles and regional geophysical data: Bulletin of the American Association of Petroleum Geologists, v. 67, no. 6, 25 p.

Lohman, S.W., 1979, Ground-water hydraulics: U.S. Geological Survey Professional Paper 708, 70 p.

Luckey, R.R., 1985, Water resources of the southeast lowlands, Missouri: U.S. Geological Survey Water-Resources Investigations Report 84-4277, 78 p.

Luckey, R.R., and Fuller, D.L., 1980, Hydrogeologic data for the Mississippi Embayment of southeastern Missouri: U.S. Geological Survey Open-File Report 79-421, 199 p.

Macfarlane, P.A., 1981, Distribution of radium-226 in the lower Paleozoic aquifers of southeast Kansas and adjacent areas, in Hemphill, D.D., ed., Trace substances in environmental health: Trace Substances in Environmental Health-IV, Columbia, Missouri, 1981, Proceedings: University of Missouri, p. 78-85.

Marcher, M.V., 1969, Reconnaissance of the water resources of the Fort Smith quadrangle, east central Oklahoma: Oklahoma Geological Survey Hydrologic Atlas 1, 4 sheets.

Marcher, M.V., and Bingham, R.H., 1971, Reconnaissance of the water resources of the Tulsa, Oklahoma, quadrangle, northeastern Oklahoma: Oklahoma Geological Survey Hydrologic Atlas 2, 4 sheets.

McCracken, M.H., 1964, The Cambro-Ordovician rocks of northeastern Oklahoma and adjacent areas: The Tulsa Geological Society Digest, v. 32, p. 49-75.

1971, Structural features of Missouri: Rolla, Missouri Division of Geology and Land Survey Report of Investigations 49, $99 \mathrm{p}$. 
McDonald, M.G., and Harbaugh, A.W., 1984, A modular three-dimensional finite-difference ground-water flow model: U.S. Geological Survey Open-File Report 83-875, 528 p.

Meinzer, O.E., 1923, Outline of ground water hydrology: U.S. Geological Survey Water-Supply Paper 494, $71 \mathrm{p}$.

Melton, R.W., 1976, The regional geohydrology of the Roubidoux and Gasconade Formations, Arkansas and Missouri: Fayetteville, University of Arkansas, M.S. thesis, 160 p.

Miller, D.E., Emmett, L.F., Skelton, John, Jeffery, H.G., and Barks, J.H., 1974, Water Resources of the St. Louis area, Missouri: Rolla, Missouri Division of Geology and Land Survey WaterResources Report 30, 114 p.

Miller, J.C., 1971, Ground-water resources of Saline County, Missouri: Rolla, Missouri Division of Geology and Land Survey Water Resources Report 26, 75 p.

Missouri Department of Natural Resources, 1985, Missouri waterquality standards: Division 20 - 10 Code of State Regulations, 20-7.031. [Available from Missouri Department of Natural Resources, P.O. Box 176, Jefferson City, MO 65102.]

Muehlberger, W.R., Hedge, C.E., Denison, R.E., and Marvin, R.F., 1966, Geochronology of the midcontinent region, United States, 3. southern area: Journal of Geophysical Research, v. 71, p. 5409-5426.

Muehlberger, W.R., Denison, R.E., and Lidiak, E.G., 1967, Basement rocks in continental interior of the United States: Bulletin of the American Association of Petroleum Geologists, v. 51, p. 2351-2380.

Muse, P.S., 1982, Ground-water resource evaluation of southwest Washington County, Arkansas: Fayetteville, University of Arkansas, M.S. thesis.

National Oceanic and Atmospheric Administration, Environmental Data and Information Service, 1951-80, Climatological DataNational Summary: Asheville, North Carolina, National Climate Data Center.

Neuman, S.P., and Witherspoon, P.A., 1969, Transient flow of groundwater to wells in multiple-aquifer systems: Berkeley, University of California, Geotechnical Engineering 69-1, $182 \mathrm{p}$.

Petersen, J.C., Broom, M.E., and Bush, W.V., 1985, Geohydrologic units of the Gulf Coast plain in Arkansas: U.S. Geological Survey Water-Resources Investigations Report 85-4116, 20 p.

Reed, E.W., Schoff, S.L., and Branson C.C., 1955, Ground-water resources of Ottawa County, Oklahoma: Oklahoma Geological Survey Bulletin 72, 203 p.

Schwalb, H.R., 1982, Geologic-tectonic history of the area surrounding the northern end of the Mississippi Embayment: Rolla, Missouri, UMR [University of Missouri, Rolla] Journal, no. 3, p. 31-42.

Sheldon, M.G., 1954, Sample descriptions and correlations for selected wells in northern Arkansas: Arkansas Resources and Development Commission Information Circular 17, 222 p.

Shepard, E.M., 1904, Missouri, in Fuller, M.L., ed., Contributions to the hydrology of eastern United States, 1903: U.S. Geological Survey Water-Supply Paper 102, p. 389-440.

1907, Underground waters of Missouri, their geology and utilization: U.S. Geological Survey Water-Supply Paper 195, 224 p.
Snyder, F.G., 1968, Tectonic history of the mid-continental United States: Rolla, Missouri, UMR [University of Missouri, Rolla] Journal, no. 1, p. 65-77.

Spruill, T.B., 1984, Assessment of water resources in lead-zinc mined areas in Cherokee County, Kansas: U.S. Geological Survey Open-File Report 84-439, 102 p.

Stephenson, L.W., and Crider, A.F., 1916, Geology and ground waters of northeastern Arkansas: U.S. Geological Survey Water-Supply Paper 399, 315 p.

Steinhilber, W.L., and Young, H.L., 1979, Plan of study for the Northern Midwest Regional Aquifer-System Analysis: U.S. Geological Survey Water-Resources Investigations 79-44, 20 p.

Stinchcomb, B.L., 1976, Precambrian algal stromatolites and stromatolitic limestones in the St. Francois Mountains of southeast Missouri, in Kisvarsanyi, E.B., ed., Contribution to Precambrian Geology No. 6: Rolla, Missouri Division of Geology and Land Survey Report of Investigations 61, p. 122-131.

Stramel, G.J., 1957, The hydraulic properties of the Ordovician rocks at Pittsburg, Kansas: Geological Survey of Kansas Bulletin 127, part 5, $178 \mathrm{p}$.

Sun, R.J., ed., 1986, Regional aquifer-system analysis program of the U.S. Geological Survey, summary of projects, 1978-84: U.S. Geological Survey Circular 1002, 264 p.

Thacker, J.L. 1974, A study of subsurface stratigraphy of the Upper Cambrian in western Missouri: Rolla, University of Missouri, M.S. thesis, $130 \mathrm{p}$.

Tikrity, S.S., 1968, Tectonic genesis of the Ozark's uplift: St. Louis, Washington University, Ph.D. dissertation, 196 p.

Todd, D.K., 1959, Ground-water hydrology: New York, John Wiley and Sons, $336 \mathrm{p}$.

U.S. Environmental Protection Agency, 1979, National secondary drinking water regulations: EPA-570/9-76-000, $37 \mathrm{p}$.

Vandike, J.E., 1981, The effects of the November 1981 liquid-fertilizer pipeline break on groundwater in Phelps County, Missouri: Rolla, Missouri Division of Geology and Land Survey, 24 p., 1 appendix.

Vineyard, J.D., and Feder, G.L., 1974, Springs of Missouri, with sections on fauna and flora by W.L. Pflieger and R.G. Lipscomb (reprinted 1982): Rolla, Missouri Division of Geology and Land Survey Water-Resources Report 29, 267 p.

Warner, D.L., Fletcher, C.S., and Cesare, J.A., 1974, Effect of mining operations on ground-water levels in the New Lead Belt, Missouri: Columbia, Missouri Water Resources Research Center, Completion Report A-060, 85 p.

Weeks, J.B. 1978, Plan of study for the High Plains Regional Aquifer-System Analysis in parts of Colorado, Kansas, Nebraska, New Mexico, Oklahoma, South Dakota, Texas, and Wyoming: U.S. Geological Survey Water-Resources Investigations 78-70, $28 \mathrm{p}$.

Williams, C.C., 1948, Contamination of deep water wells in southeastern Kansas: Geological Survey of Kansas Bulletin 76, 28 p.

Wise, O.A., and Caplan, W.M., 1979, Silurian and Devonian rocks of northern Arkansas: Arkansas Geological Commission Information Circular 25, $14 \mathrm{p}$.

Zeller, D.E., ed., 1968, The stratigraphic succession in Kansas: Geological Survey of Kansas Bulletin 189, 81 p. 

Instructions on ordering publications of the U.S. Geological Survey, along with prices of the last offerings, are given in the currentyear issues of the monthly catalog "New Publications of the U.S. Geological Survey." Prices of available U.S. Geological Survey publications released prior to the current year are listed in the most recent annual "Price and Availability List." Publications that are listed in various U.S. Geological Survey catalogs (see back inside cover) but not listed in the most recent annual "Price and Availability List" are no longer available.

Reports released through the NTIS may be obtained by writing to the National Technical Information Service, U.S. Department of Commerce, Springfield, VA 22161; please include NTIS report number with inquiry.

Order U.S. Geological Survey publications by mail or over the counter from the offices given below.

\section{BY MAIL}

\section{Books}

Professional Papers, Bulletins, Water-Supply Papers, Techniques of Water-Resources Investigations, Circulars, publications of general interest (such as leaflets, pamphlets, booklets), single copies of Earthquakes \& Volcanoes, Preliminary Determination of Epicenters, and some miscellaneous reports, including some of the foregoing series that have gone out of print at the Superintendent of Documents, are obtainable by mail from

\section{U.S. Geological Survey, Map Distribution Box 25286, MS 306, Federal Center Denver, CO 80225}

Subscriptions to periodicals (Earthquakes \& Volcanoes and Preliminary Determination of Epicenters) can be obtained ONLY from the

\section{Superintendent of Documents \\ Government Printing Office \\ Washington, DC 20402}

(Check or money order must be payable to Superintendent of Documents.)

\section{Maps}

For maps, address mail orders to

\section{U.S. Geological Survey, Map Distribution Box 25286, Bldg. 810, Federal Center Denver, CO 80225}

\author{
Residents of Alaska may order maps from \\ U.S. Geological Survey, Earth Science Information Center \\ 101 Twelfth Ave., Box 12 \\ Fairbanks, AK 99701
}

\section{OVER THE COUNTER}

\section{Books and Maps}

Books and maps of the U.S. Geological Survey are available over the counter at the following U.S. Geological Survey offices, all of which are authorized agents of the Superintendent of Documents.

- ANCHORAGE, Alaska-4230 University Dr., Rm. 101

- LAKEWOOD, Colorado-Federal Center, Bldg. 810

- MENLO PARK, California-Bldg. 3, Rm. 3128, 345 Middlefield Rd.

- RESTON, Virginia-National Center, Rm. 1C402, 12201 Sunrise Valley Dr.

- SALT LAKE CITY, Utah-Federal Bldg., Rm. 8105, 125 South State St.

- SPOKANE, Washington-U.S. Post Office Bldg., Rm. 135, W. 904 Riverside Ave.

- WASHINGTON, D.C.-Main Interior Bldg., Rm. 2650, 18th and C Sts., NW.

\section{Maps Only}

Maps may be purchased over the counter at the U.S. Geological Survey offices:

- FAIRBANKS, Alaska-New Federal Building, 101 Twelfth Ave.

- ROLLA, Missouri-1400 Independence Rd.

- STENNIS SPACE CENTER, Mississippi-Bldg. 3101 


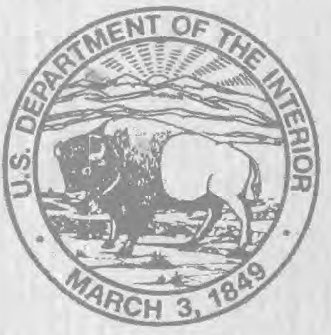

